UNIVERSIDAD NACIONAL DE LA PLATA

FACULTAD DE HUMANIDADES Y CIENCIAS DE LA EDUCACIÓN SECRETARÍA DE POSGRADO

\title{
EL PROBLEMA DE LA ESTETIZACIÓN Y LA RECONFIGURACIÓN DE LA EXPERIENCIA EN LA FILOSOFÍA DE WALTER BENJAMIN
}

\author{
Prof. Tatiana Staroselsky
}

Tesis para optar por el grado de Doctora en Filosofía

Director: Dr. Francisco Naishtat

Codirectora: Dra. Analía Melamed

15 de diciembre de 2020 
Hoy pensado está todo. Se trata, por lo tanto, de hacer altos en los tan abundantes como reducidos pensamientos. Pasar la noche en un pensamiento. Si realmente he hecho noche en él, voy a saber de él algo insospechado por su constructor.

Walter Benjamin, 2007, p. 279 


\section{Índice}

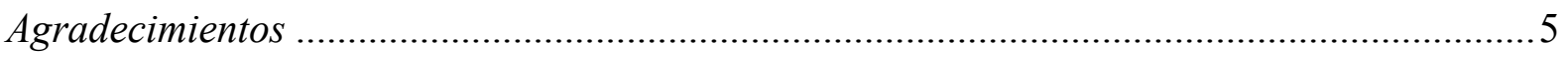

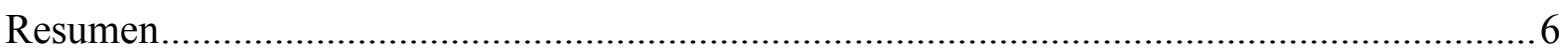

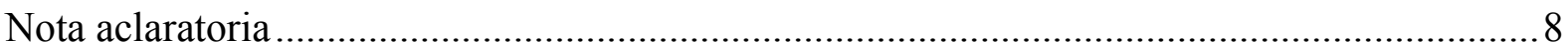

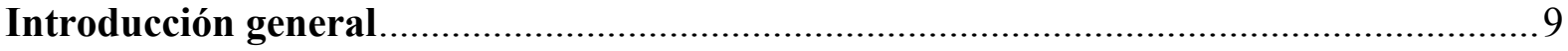

Primera sección: El problema de la estetización en la filosofía de Walter Benjamin:

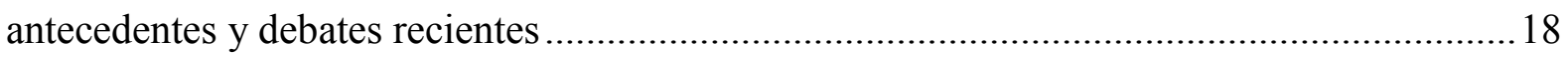

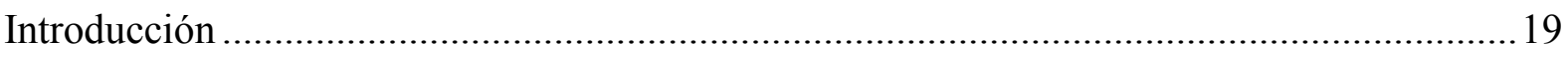

Capítulo 1. El fenómeno de la estetización en la filosofía reciente .......................................21

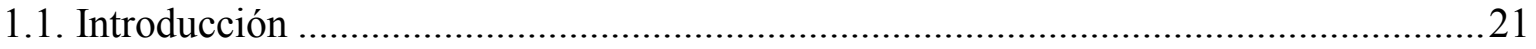

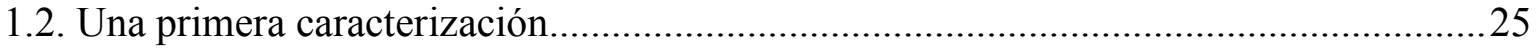

1.3. La estetización como estilización: la centralidad de la belleza ....................................32

1.4. La estetización como fascinación: la puesta en marcha del espectáculo .......................43

1.5. La estetización como una forma de configuración de la experiencia: la centralidad de

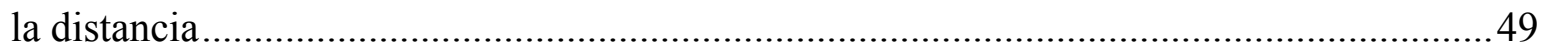

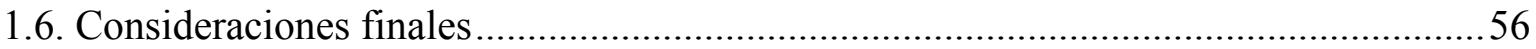

Capítulo 2. El motivo de la estetización en Georg Simmel ................................................58

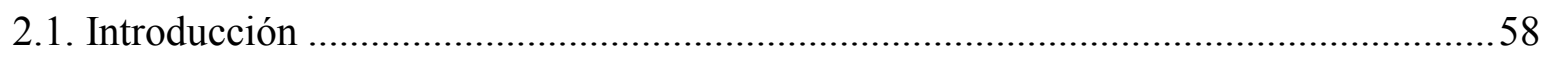

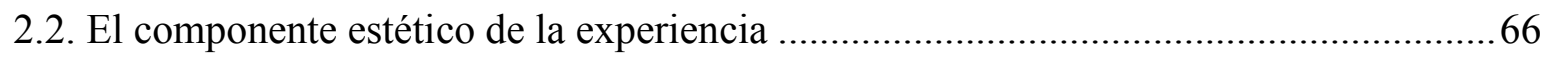

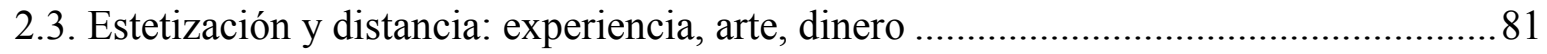

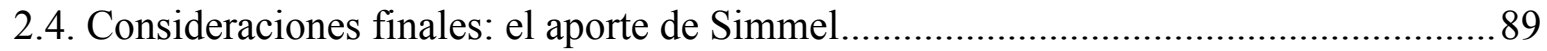

Capítulo 3. El problema de la estetización en Walter Benjamin .............................................94

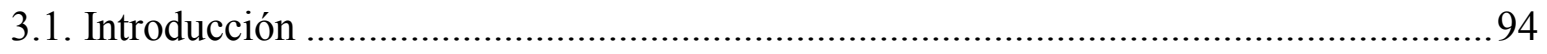

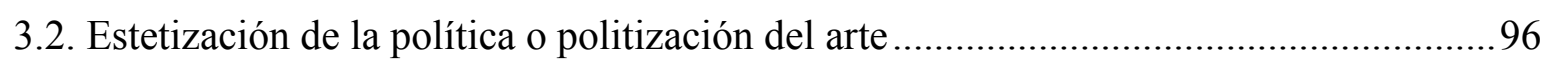

3.3. Estetización del pasado o politización de la historia............................................... 115

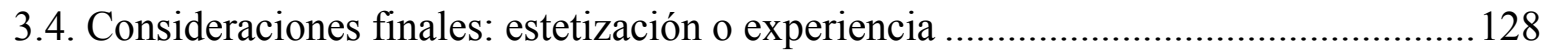

Segunda sección: La crisis de la experiencia en la filosofía de Walter Benjamin: diagnósticos

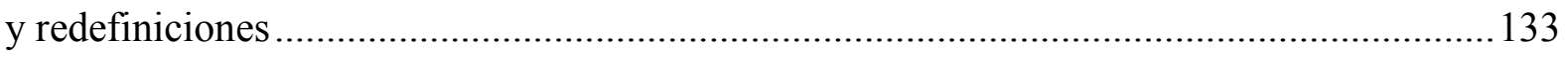

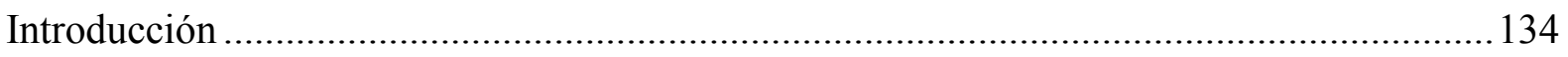

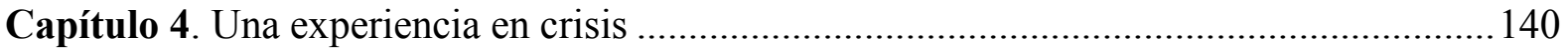

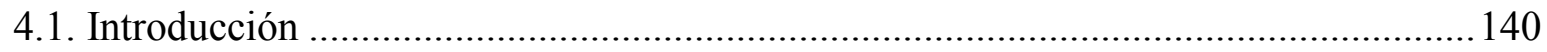


4.2. El diagnóstico benjaminiano

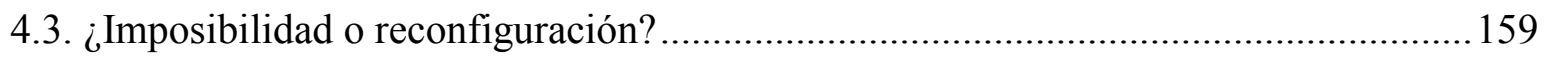

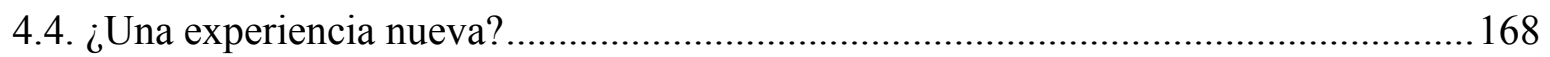

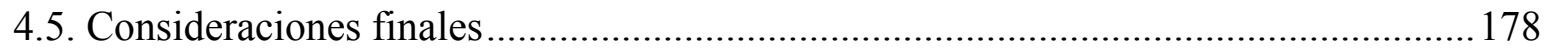

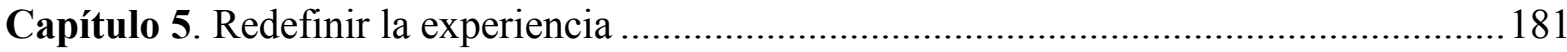

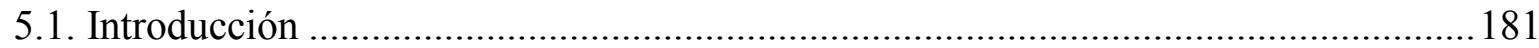

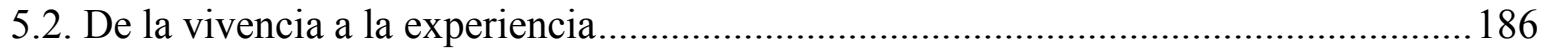

5.3. El ritmo y el tiempo de la experiencia: trabajo y juegos de azar ................................ 193

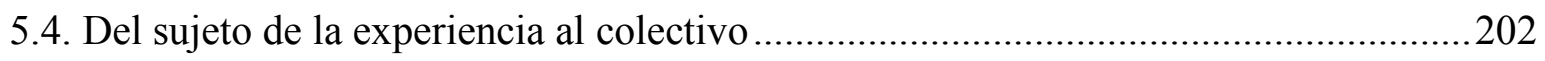

5.5. De la experiencia del mundo a la experiencia con él ...............................................214

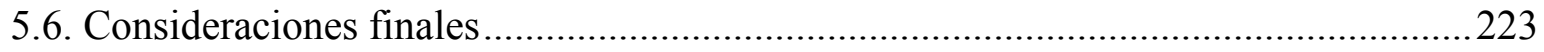

Tercera sección: Las posibilidades de la filosofía: contrastes y potencias en tiempos críticos

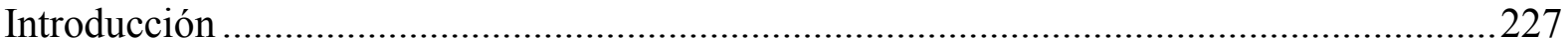

Capítulo 6. La perspectiva de Martin Heidegger ................................................................231

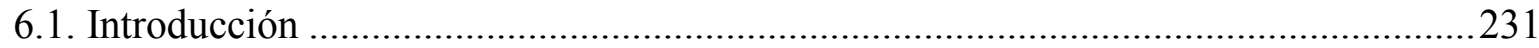

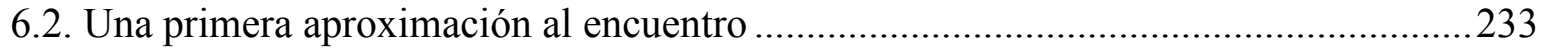

6.3. La relación del hombre con el mundo: la importancia del cuidado ............................240

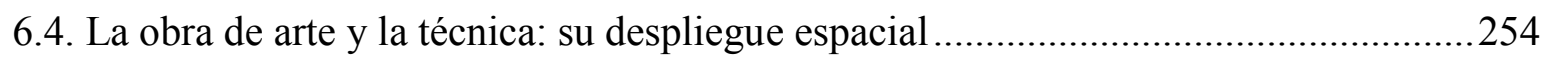

6.5. Historia, temporalidad y modos de experimentar el pasado ...................................2 275

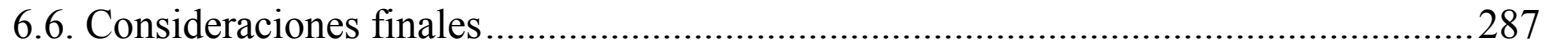

Capítulo 7. En busca de una escritura no estetizante ..........................................................293

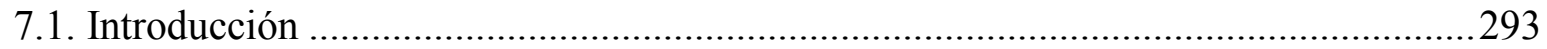

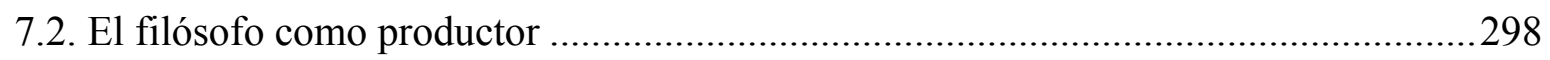

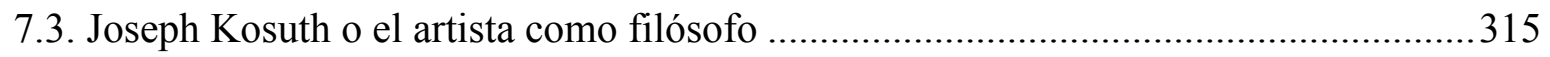

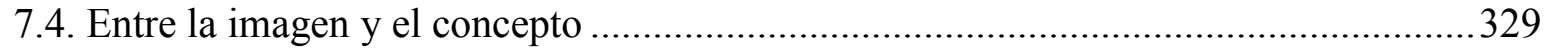

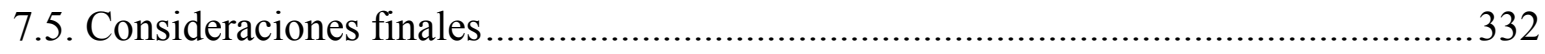

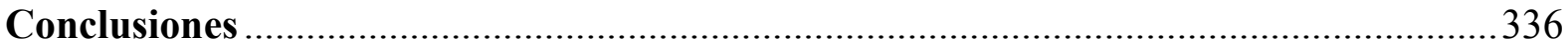

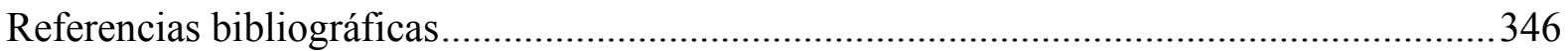




\section{Agradecimientos}

Esta tesis ha sido posible gracias al apoyo que significó la beca de CONICET, que me permitió desarrollar mis actividades en el Instituto de Investigación en Humanidades y Ciencias Sociales (FaHCE-UNLP/CONICET) y, a partir de su conformación, en el Centro de Investigaciones en Filosofía (CIeFi) que allí se aloja. A dichas instituciones públicas, a sus autoridades y sus colaboradorxs y a todxs lxs que luchan día a día por mantenerlas activas e inclusivas, va mi agradecimiento.

Asimismo, quiero agradecer a las instituciones y personas que me permitieron complementar mi formación visitando otras universidades y poniéndome en contacto con grupos de investigación, docentes e investigadorxs que me dieron la posibilidad de ampliar la perspectiva desde la que abordo hoy la filosofía de Walter Benjamin. Agradezco entonces a la Red de Macro Universidades Públicas de América Latina y el Caribe, que me permitió realizar una estancia académica en la UNAM bajo la dirección de la Dra. Esther Cohen, que fue muy relevante en la etapa de mis actividades formativas, y al Servicio Alemán de Intercambio Académico (DAAD), por darme la oportunidad de mejorar mis conocimientos del idioma alemán y de instalarme en Berlín y redactar buena parte de estas páginas durante mi estancia en la Universidad Humboldt y el Archivo Walter Benjamin bajo la dirección del Prof. Dr. Daniel Weidner. A mis tutores en esas instancias, y al personal del Archivo, les agradezco también muy especialmente por su generosidad.

Centralmente, les agradezco a mis directores, Francisco y Analía, porque además de haberme enseñado, con respeto y afecto, a trabajar en este campo, escucharlxs y leerlxs fue y es siempre, para mí, una experiencia enriquecedora. Esta tesis es, sin dudas, tan mía como de ellxs. Extiendo este agradecimiento, también, a todos los miembros de los equipos de investigación y lectura en los que participo y participé, que afortunadamente son muchos.

Quiero agradecerles, además, a mi familia, por la confianza, el apoyo, el cariño y la paciencia en los años de trabajo en esta investigación, y a mis amigxs, por acompañar este proceso y quitarle solemnidad. Muy especialmente: mamá, Hanni, Nati, gracias de todo corazón.

Por último, a Fede, por ser un gran interlocutor y un lector atento, pero sobre todo por ser mi compañero, en el sentido más profundo del término. 


\section{Resumen}

En la presente investigación ofrecemos una lectura conjunta del problema de la estetización y del diagnóstico de una crisis y una reconfiguración de la experiencia en la filosofía de Walter Benjamin, en tanto sostenemos que los dos motivos pueden ser comprendidos mejor como partes de una misma lectura de la época. En efecto, el problema de la estetización, en tanto se presenta en Benjamin como el triunfo de la relación contemplativa con el entorno, constituye el punto más álgido del empobrecimiento de la experiencia que el autor observa como signatura de su tiempo. A su vez, las tareas que indica como respuestas posibles ante los procesos estetizantes se centran en la puesta en marcha de una operación de politización, es decir, en la necesidad de hacer una experiencia transformadora con aquel mundo que se tornó mera imagen. En este sentido, proponemos leer los conceptos de experiencia y estetización, en la obra de Benjamin, como dos polos de un continuo en tanto que, si el objeto se presenta, en la relación estetizante, como algo colocado en frente, la experiencia en sentido estricto, como experiencia transformadora, no puede tener lugar.

Organizamos la exposición en torno a tres secciones, a saber, una primera centrada en el problema de la estetización, una segunda dedicada a la crisis y reconfiguración de la experiencia en la filosofía de Benjamin y la redefinición de este concepto en su obra, y una tercera en la que exploraremos las posibilidades de la filosofía en el contexto de estos diagnósticos. Asimismo, y dado que se trata de una investigación centrada en la filosofía de Benjamin pero estructurada en torno a un eje problemático, dedicamos algunos capítulos y apartados a otros autores, como explicitaremos a continuación.

En la primera sección de la tesis, "El problema de la estetización en la filosofía de Walter Benjamin: antecedentes y debates", nos centramos en el motivo de la estetización en tres capítulos. En el primero (Cap. 1 "El fenómeno de la estetización en la filosofía reciente”), presentamos algunas líneas interpretativas e investigaciones actuales que demarcan un campo problemático en torno al problema de la estetización, así como ofrecemos también una taxonomía de las formas en que el concepto opera en los diferentes diagnósticos en los que aparece. En el segundo capítulo (Cap. 2 "El motivo de la estetización en Georg Simmel”), hacemos foco en la figura de Simmel, en tanto constituye un antecedente muy relevante para comprender la estetización, que se prefigura en su obra como motivo. Defendemos la idea de que este autor sentó las bases para que un diagnóstico como el benjaminiano fuera posible, al 
poner en el foco de atención el modo en que la dimensión estética de nuestra vida cotidiana fue acrecentando, gradualmente, su importancia hasta impregnar e informar una gran parte de nuestras actividades y de los aspectos de nuestra vida. En el tercer capítulo introducimos la perspectiva benjaminiana sobre la estetización, en torno al arte y su relación con la política, pero también en torno a la historia y el pasado (Cap. 3 "El problema de la estetización en Walter Benjamin").

La segunda sección de la tesis ("La crisis de la experiencia en la filosofía de Walter Benjamin: diagnósticos y redefiniciones") se centra en la cuestión de la experiencia en el marco de la filosofía de Benjamin, en tanto concepto que articula su producción, desde el diagnóstico de una crisis de la experiencia en su época, que pone en duda su misma posibilidad (Cap. 4 "La experiencia en crisis"), hasta el modo en que, a través de este diagnóstico, Benjamin modifica profundamente el concepto mismo de experiencia, central en la tradición filosófica, ofreciendo una conceptualización que abandona ciertos presupuestos modernos y resulta productiva tanto filosófica como políticamente (Cap. 5 "Redefinir la experiencia").

La última sección de la tesis ("Las posibilidades de la filosofía: contrastes y potencias en tiempos críticos") la dedicamos a explorar, por un lado, algunas ideas de Heidegger que tensan relaciones complejas con la concepción benjaminiana (Cap. 6 "La perspectiva de Martin Heidegger") y, por el otro, las reflexiones de Benjamin en torno a las formas y los formatos de escritura y su búsqueda de un modo de filosofar flexible que logre dar cuenta de aquello a lo que se aboca, sin convertirlo en el objeto acabado de un sistema cerrado falseando sus tensiones (Cap. 7 "En busca de una escritura no estetizante"). La búsqueda de una tal escritura, que puede ser pensada como una de las tareas de la filosofía, caracteriza particularmente a la filosofía de Benjamin, gestada al calor de cambios profundos en la forma en que se organiza la vida humana, y la vuelve capaz de dar cuenta de las transformaciones que marcaron la época, abandonando la pretensión de sistema y el reinado del concepto y explorando otras formas de decir.

Palabras clave: estetización; experiencia; politización; arte; historia; Walter Benjamin; Martin Heidegger; Georg Simmel. 


\section{Nota aclaratoria}

Para las citas y referencias, seguimos la Sexta Edición del manual de estilo de la American Psychological Association (APA). Por su parte, las citas y referencias a los textos de Walter Benjamin, de Georg Simmel y de Martin Heidegger corresponden, por lo general, a las versiones de los textos en español. En algunos casos, no obstante, la versión que se indica es la original en alemán, y la traducción que se ofrece de los fragmentos citados es propia. Asimismo, y como es habitual en las investigaciones sobre la obra de Benjamin, remito a la edición en alemán de su obra completa, Gesammelte Schriften I-VII (que indicamos como GS, seguido del número del volumen y la página), así como de su correspondencia reunida, Gesammelte Briefe (abreviada como GB).

En torno a Simmel, remito también en algunos casos a su obra reunida en alemán, Gesamtausgabe in 24 Bänden. Por último, para la obra de Heidegger, y si bien se ofrecen, en todos los casos, las citas de los textos en sus traducciones al español, se indica a su vez en muchos casos la referencia a la versión original (la Gesamtausgabe reunida por Vittorio Klostermann). Esta referencia se indica, como en el caso de Benjamin, luego de la referencia a la versión española, y con la abreviatura habitual, GA, seguida del número del volumen y la página. Las referencias a la versión original de Ser y tiempo (Sein und Zeit), se indican con la abreviatura $\mathrm{SuZ}$, seguida de la página.

Pese a consignar las citas de los autores en sus versiones en español (en traducciones editadas o propias), y teniendo en cuenta la dificultad que presentan algunas controversias en torno a la traducción de algunos conceptos y pasajes clave, indicamos entre corchetes algunos términos y frases en alemán. Finalmente, en el caso de aquellos textos críticos de los que no hubiera traducción al español, las traducciones del alemán, del inglés y del portugués son, en todos los casos en los que no se indique lo contrario, propias. 


\section{Introducción general}

En "El autor como productor", texto para una conferencia que planeaba pronunciar en París en 1934 en un evento que, según parece, no tuvo lugar, escribe Benjamin refiriéndose a la fotografía:

es cada vez más sutil y moderna, y el resultado es que ya no se puede fotografiar una casa o un montón de basura sin transfigurarlo [ohne ihn zu verklären]. La fotografía no está sin duda en condiciones de decir sobre una represa o fábrica otra cosa que ésta: el mundo es bello [die Welt ist schön]. (2009b, p. 307; GS II 693)

El mundo es bello [Die Welt ist schön] es, a su vez, un libro publicado en 1928 por el fotógrafo alemán Albert Renger-Patzsch, y el nombre de la famosa colección de cien imágenes que allí se muestra y por medio de la cual, según Benjamin, el arte fotográfico de la Nueva Objetividad [Neue Sachlichkeit] alcanza su apogeo, logrando "convertir incluso la miseria en directo objeto de disfrute [auch noch das Elend (...) zum Gegenstand des Genusses zu machen]" (Benjamin, 2009b, p. 307; GS II 693). Renger-Patzsch retrata, sin hacer uso de trucos ni técnicas vanguardistas, objetos de diferente naturaleza que intenta presentar "al desnudo". Se trata de fotografías en blanco y negro de plantas, animales, edificios, rostros humanos, tejados y productos de fabricación en serie que adquieren aires de familia en tanto el tratamiento de la imagen es en todos los casos similar. Las imágenes acentúan lo formal y encuentran, desde ese prisma, similitudes en objetos de naturaleza diversa.

Como menciona Carl Gelderloos (2014) en su reconstrucción del debate entre Benjamin y Bertolt Brecht en torno a esta publicación, la fotografía de Renger-Patzsch es, para estos pensadores, una sinécdoque, un caso paradigmático al que se abocan, no tanto para discutir sus 
propios logros o falencias, sino en su carácter de ejemplo de la corriente de la Nueva Objetividad y, más allá, para discutir las potencialidades y los peligros de la fotografía como tal, esto es, como arte, como forma de reflejar la realidad, como aparato técnico y como aparato óptico capaz de modificar o educar nuestra percepción ${ }^{1}$.

Las acusaciones que se le endilgan a Renger-Patzsch en este contexto son dos: por un lado, su pretensión de reflejar la realidad de modo objetivo ${ }^{2}$ es condenada casi como un infantilismo, un realismo estético retrógrado y naif. Por el otro, y es aquí donde nos interesa hacer hincapié, sus fotografías encarnan, para los teóricos del arte $-\mathrm{y}$ los pensadores de lo político-que fueron Benjamin y Brecht, la estetización de la realidad, esto es, la transfiguración de lo real en mera apariencia agradable y en imagen a ser contemplada.

Brecht se refiere a la fotografía de Renger-Patzsch para colocarla como una forma de arte cuyo principal interés radica en mostrar, no ya que el mundo es bello, sino más bien que la vida es bella a pesar de todo. En este sentido, las imágenes estetizadas de la realidad, carentes de toda capacidad de denuncia ${ }^{3}$, se ponen al servicio del mantenimiento del statu quo. Como en la fotografía publicitaria -que fue, a su vez, la especialidad de Renger-Patzsch-, el embellecimiento de lo retratado, que no es ni más ni menos que el mundo, sirve para venderlo. La transfiguración estética, en este contexto, opera no sólo duplicando lo real en una imagen embellecida y digna de ser admirada, sino como una educación de la mirada que aprende a

\footnotetext{
${ }^{1}$ Berti (2015) apunta en este sentido que "el error de la crítica de arte liberal estriba en la discusión sobre la fotografía como arte, cuando en rigor de verdad el problema está en las modificaciones perceptuales que introduce la técnica, es decir, el arte como fotografía” (p. 210).

${ }^{2}$ Esta pretensión de objetividad, lejos de ser novedosa, es clásica de la fotografía. Es bien conocida la posición de Baudelaire, quien, si bien para oponerse a la consideración de la fotografía como un arte, hace hincapié en esta supuesta capacidad suya de reflejar el mundo tal y como es. En "El público moderno y la fotografía", sostiene que el credo que se propagaba en Francia en cuestiones de estética era aquel que creía en la naturaleza y en que el arte "es y no puede ser más que la reproducción exacta de la naturaleza", y agrega: "un Dios vengador ha atendido a los ruegos de esta multitud. Daguerre fue su Mesías. (...) A partir de ese momento, la sociedad inmunda se precipitó, como un solo Narciso, a contemplar su imagen trivial en el metal.” (Baudelaire, 1976, p. 277).

${ }^{3}$ Esta asociación entre estetización y incapacidad de denuncia es, como analizaremos más profundamente para el caso de Leni Riefenstahl, algo problemática. En la obra de la documentalista, paradójicamente, el reflejo estetizante de las festividades nazi tiene una cierta potencia crítica, aun por fuera de la voluntad de la artista.
} 
encontrar, allí donde hay una realidad compleja, una simple imagen que espera ser juzgada con criterios importados del arte.

Según el propio fotógrafo, "quien conoce un paisaje debe reconocerlo en una fotografía" tanto como "quien no lo conoce debe obtener la correcta idea de él" (citado por Gelderloos, 2014, p. 558). Esta concepción de la fotografía como espejo fiel del mundo puede resultar esclarecedora para comprender la crítica de Benjamin y Brecht: quien no conoce el mundo, entonces, debería hacerse, viendo las fotografías de Renger-Patzsch, una idea adecuada de él, y que el mundo sea hermoso no parece constituir una tal idea.

Benjamin empleará en 1936, en su ensayo sobre "La obra de arte en la época de su reproductibilidad técnica", su célebre par estetización de la política - politización del arte. Aun así, la denuncia de la aparición de una mirada estetizante sobre el mundo que, lejos de operar a la par de otras perspectivas, obstruye una lectura crítica de la realidad, ya está presente en su reflexión sobre Renger-Patzsch y, antes aún, en la reseña de Guerra y guerreros, de Ernst Jünger, que escribe en 1930.

La preocupación que compartieron Benjamin y Brecht en torno a la colonización que los criterios estéticos operan en nuestra mirada y nuestras producciones -artísticas, pero también, como veremos luego, intelectuales- resulta sumamente relevante en el seno de las discusiones filosóficas de nuestro presente. En efecto, múltiples diagnósticos de la actualidad, como la estetización general de la existencia (Vattimo, 1987) o la estetización del mundo (Lipovetsky y Serroy, 2014), pueden inscribirse en una tradición que encuentra en Benjamin a una de sus figuras clave.

Asimismo, otra figura muy relevante para los estudios sobre la estetización es la de Georg Simmel, quien describió el cambio de época que significó el cambio de siglo de una manera brillante y cuyas observaciones sobre fenómenos de la vida cotidiana tienen la capacidad de dar cuenta de aquello que en una teoría de la sociedad como tal no emerge. En sus 
ensayos breves, Simmel presenta varios elementos fundamentales para la comprensión del fenómeno que nos ocupa, en tanto da cuenta de cómo el sujeto se torna pasivo, las cosas se distancian y la realidad comienza a ser percibida como imagen. Asimismo, vislumbra la potencialidad del arte como aparato que moldea nuestra subjetividad y nuestra forma de ver el mundo y, lejos de entender este hecho de manera inocente, lo liga con un proceso en el que el mundo se nos aleja y se convierte en objeto de apreciación estética. Esto resulta particularmente significativo para nuestro estudio, en tanto nos centraremos en la estetización como un problema con una clara dimensión política que, si bien Simmel no enuncia, permite comenzar a delinear.

A su vez, si se comprende la estetización como una relación con el entorno que, al reducirlo a mero objeto, no logra resultar significativa o transformadora, es posible pensarla como parte de la crisis de la experiencia a la que se refiere Benjamin en "Experiencia y pobreza", de 1933, o incluso como su punto más crítico. En este sentido, los motivos de la experiencia y la estetización se revelan como los dos extremos de un continuo en tanto que, si el mundo se presenta como algo colocado en frente, como un objeto de apreciación estética, la experiencia en sentido estricto, como experiencia transformadora, no puede tener lugar.

El concepto de experiencia tal y como emerge de la filosofía de Benjamin es un concepto con una densidad política muy significativa, y a su vez las tareas de politización del arte y de la historia aparecen, en los textos del autor, ligadas a la posibilidad de hacer una experiencia con la obra de arte y con el pasado. En efecto, lo político en Benjamin está referido fundamentalmente a los modos de organizar la experiencia (Kang, 2014, p. 130), y la estetización se revela como una forma de despolitización de dicha relación, que encuentra su punto más álgido en la orquestación de las masas que propone el fascismo.

El abordaje benjaminiano del concepto de experiencia - uno de los motivos más estudiados de su pensamiento-, lejos de remitir a las concepciones heredadas de la experiencia, 
condensa las principales críticas que este filósofo dirige a la tradición filosófica a la vez que opera algunos desplazamientos teóricos que le permiten ofrecer un análisis original que da cuenta de la complejidad, las transformaciones y las potencialidades de los modos de relación con el mundo que se configuran en el siglo XX. En efecto, al articular sus reflexiones sobre la experiencia en torno a un cuestionamiento radical de su misma posibilidad, Benjamin logra desandar muchos de los presupuestos que signan al concepto en su uso tradicional.

Sus reflexiones han dado lugar, así, a lecturas encontradas acerca de las posibilidades que se abren tras el empobrecimiento de las formas de experiencia conocidas: para algunos intérpretes, el diagnóstico benjaminiano nos condena a pensar en la absoluta imposibilidad de la época contemporánea para alojar experiencias enriquecedoras; para otros, es posible vislumbrar una cierta reconfiguración de los modos de experimentar, en los que la experiencia encontraría la forma de sobrevivir. En torno a ello resultan particularmente interesantes las interpretaciones de Didi-Huberman y de Jean- Louis Déotte, quien aborda el tema a partir de la introducción del concepto de "aparato", que toma de Benjamin pero que reinterpreta más allá de él. En efecto, si pensamos la crisis como crisis del aparato y no ya de la experiencia en sí misma -en tanto no hay algo así como una experiencia despojada de aparatos-, y si entendemos a su vez la crisis como un proceso que, en su marcha, motiva reacciones valiosas, algo de la experiencia encontraría una salvación. Aun así, y si la experiencia es tal en tanto está configurada por un aparato, debemos aceptar entonces que las experiencias que los nuevos aparatos podrían hacer posibles no se identifican ya con aquella cuya pérdida se constata.

A su vez, además de permitir pensar en algunas nuevas formas de experiencia que emergen tras la crisis de sus modos y soportes tradicionales, Benjamin reelabora el concepto mismo de experiencia de modo tal que se transforma en una herramienta valiosa para entender de un modo novedoso, entre otros fenómenos, el conocimiento, la historia y el arte, ofreciendo una conceptualización que abandona muchos supuestos tradicionales y logra dar cuenta de 
dimensiones de la experiencia que este marco invisibilizaba. Asimismo, al cuestionar desde lo más profundo la concepción del hombre y de su relación con el mundo, para desmontar así los mitos que implica, la teoría benjaminiana de la experiencia es capaz de adquirir una potencialidad política que está ausente en otras concepciones de la experiencia.

Ahora bien, la crisis o empobrecimiento de la experiencia, en tanto diagnóstico de una pérdida y una transformación que tienen lugar en el seno mismo de nuestra relación con el mundo, fue analizada también por Martin Heidegger, quien, si bien en el marco de un universo teórico claramente diferente, mostró en su obra, tanto como Benjamin, una preocupación por el estado de la experiencia en la época moderna, a la que se refirió en términos de la época de la imagen del mundo, y buscó nuevas formas de dar cuenta de la experiencia humana, que dejaran atrás los marcos de la metafísica y la epistemología tradicionales.

Y es que Benjamin y Heidegger compartieron más que la época: tuvieron en común también la sensibilidad para percibir la "ruptura de la tradición” (Amengual, Cabot y Vermal, $2008)^{4}$ que signa esa época de "gran crisis cultural que explosiona con los fascismos y la segunda guerra mundial" (p. 21), crisis que vivieron de maneras radicalmente diferentes y que intentaron mostrar por medio de su escritura. Heidegger fue a su vez, tanto como Benjamin, un crítico lúcido e incansable de las formas de objetivación del mundo que lo comprenden, desde la teoría pero no sin consecuencias importantes para la praxis, como un mero objeto de observación, control y medida.

Asimismo, tanto en Benjamin como en Heidegger -y en Simmel- es posible descubrir un esfuerzo intelectual notable por encontrar o producir las categorías que logren dar cuenta de las modificaciones de la experiencia en el siglo XX, así como una preocupación conjunta por el estado de dicha experiencia, si bien esta preocupación está signada, como es sabido, por

\footnotetext{
${ }^{4}$ Arendt (1990) se refiere también a una "ruptura en la tradición" (p. 186) y a la afinidad entre esta ruptura y la figura del coleccionista, y lo hace precisamente allí donde sostiene que Benjamin y Heidegger tenían mucho en común en torno a su trabajo con la tradición.
} 
convicciones políticas bien diferentes. En Heidegger, el pensamiento se pierde en una selva de reflexiones poetizantes que se alejan de la encrucijada en la que sus ideas pueden cruzarse con las de Benjamin, y se apaga en la sombra de un compromiso político cuestionable y de una disculpa pública que nunca tuvo lugar. En la obra de Benjamin, por su parte, la salida nostálgica de la crisis de la experiencia es evitada, y en su lugar se abre una exploración de las posibilidades del presente, que se condice con un interés en las nuevas formas de producción del arte y del trabajo intelectual, en estrecha relación con el análisis de las posibilidades abiertas por las innovaciones técnicas.

En efecto, tal y como espera del arte que pueda decir algo más que el mundo es bello, Benjamin esperará del trabajo intelectual, y de la filosofía, una actividad muy diferente de la de sostener la ficción de que el mundo tiene sentido, y pondrá en marcha formas de experimentación con la escritura y sus formatos que lo acercan al lenguaje de las vanguardias y del arte conceptual. Las innovaciones benjaminianas en torno a la exposición son experimentos que buscan, ya no reflejar una realidad prelingüística dada, sino intervenirla partiendo del propio aparato productivo con el que se trabaja en filosofía. En este marco, la pretensión sistemática que caracterizó tradicionalmente a la disciplina se revela, en ocasiones, como el intento de imponer orden en un mundo de caos, de imprimir causalidades simples y taxonomías tranquilizadoras a la realidad, que operan como lentes para estructurar lo dado como material de manuales y museos.

En este contexto, y en tanto consideramos que su enfoque logra iluminar la complejidad y el peligro de los procesos estetizantes evitando reduccionismos y diagnósticos apresurados, ofreceremos en la presente investigación una lectura de este problema en la filosofía de Walter Benjamin, así como una interpretación de la reconfiguración de la experiencia que fue uno de los motivos centrales de su obra. El recorrido que proponemos por el pensamiento de Benjamin es, entonces, problemático, por lo que el análisis de sus escritos no será el único recurso de 
nuestra argumentación, sino que el autor se encontrará, en estas páginas, con otros pensadores, como Simmel y Heidegger, pero también con artistas, como Joseph Kosuth.

En la primera sección de la tesis, "El problema de la estetización en la filosofía de Walter Benjamin: antecedentes y debates recientes", comenzaremos presentando algunas líneas interpretativas e investigaciones actuales que demarcan un campo problemático en torno a la estetización (Cap. 1 "El problema de la estetización en la filosofía reciente"), para centrarnos luego, pasando por Simmel (Cap. 2 "El motivo de la estetización en Georg Simmel"), en cómo la perspectiva benjaminiana permite delinear un concepto de estetización que logra hacer un aporte en los debates actuales (Cap. 3 "El problema de la estetización en Walter Benjamin"). En la filosofía de Benjamin, este problema se articula, principalmente, en torno a la relación entre el arte y la política y se enuncia en el par estetización de la política/ politización del arte. Aun así, y como sostendremos, la crítica benjaminiana al historicismo puede ser comprendida, también, como la denuncia de una relación estetizante con el pasado, a la vez que algunas de sus consideraciones sobre la tarea de la filosofía admiten la lectura de una cierta estetización del pensamiento, que Benjamin trató de combatir mediante su búsqueda de formatos no totalizantes de escritura.

La segunda sección de la tesis, "La crisis de la experiencia en la filosofía de Walter Benjamin: diagnósticos y redefiniciones", se centrará en la cuestión de la experiencia: nos detendremos, específicamente, en la crisis de la experiencia a la que se refiere Benjamin (Cap. 4 "La experiencia en crisis"), y en el modo en que, a través de este diagnóstico, el berlinés modifica profundamente el concepto mismo de experiencia, ofreciendo una conceptualización que abandona los presupuestos tradicionales y permite pensar en una experiencia que no necesita ya de la figura de un sujeto (Cap. 5 "Redefinir la experiencia").

La última sección de la tesis ("Las posibilidades de la filosofía: contrastes y potencias en tiempos críticos") la dedicaremos a explorar, por un lado, la propuesta teórica de Heidegger 
en su carácter de interlocutor polémico de Benjamin (Cap. 6 "La perspectiva de Martin Heidegger") y, por el otro, las reflexiones benjaminianas en torno a las posibilidades de la filosofía en el contexto que delineamos, tras su abandono de la pretensión de sistema, su cuestionamiento del reinado del concepto y su exploración de otras formas de decir y de mostrar (Cap. 7 "En busca de una escritura no estetizante"). 


\section{Primera sección}

El problema de la estetización en la filosofía de Walter Benjamin: antecedentes y debates recientes 


\section{Introducción}

Estetización de la vida, estetización del mundo, estetización de la política: el motivo de la estetización aparece, en el presente, como una forma de dar cuenta de un modo de relación con el entorno que sufrió modificaciones sustanciales y que resulta, de alguna manera, problemático. Así, el concepto se pone en función de diagnósticos de tono variado sobre nuestra cotidianidad y nuestra vida política y social, y abandona el emplazamiento estrictamente filosófico para volverse parte de discursos accesibles a públicos no expertos.

En efecto, muchos son los autores que, en la filosofía actual, se hacen eco del diagnóstico benjaminiano, a tal punto que la estetización ha pasado a ser un eje central en muchas descripciones del mundo en que vivimos. Tanto es así que, ante diagnósticos múltiples que se refieren a la estetización de la política, del mundo, de la vida, del pensamiento, de los vínculos, y hasta del arte, cabe hoy preguntarse, con Uta Kösser, hasta qué punto es posible emplear el término de modo que aún tenga sentido y proporcione información sobre el proceso específico al que se refiere (Kösser, 2006, p. 460).

En La estetización del mundo, de 2014, Gilles Lipovetsky y Jean Serroy definen este fenómeno como un proceso por medio del cual la sociedad y el individuo devienen estéticos, como parte del avance del "individualismo consumista experiencial o transestético" (2014, p. 103). Estético, aquí, no refiere ya al mundo del arte, sino que lo supera en un contexto en el que lo que obtiene prelación es la construcción de una cierta mirada distanciada que juzga lo que ve en su carácter de imagen. Así como para Benjamin la fotografía sólo podía enunciar la belleza del mundo, hoy somos testigos, por ejemplo, del modo en que el turismo de la pobreza muestra en las redes sociales la belleza de un mundo estructurado violentamente por el capital. 
En los más de ochenta años que separan al diagnóstico benjaminiano del estudio de Lipovetsky y Serroy, el concepto de estetización fue comprendido de maneras múltiples y puesto en función de argumentaciones de diferente carácter. Es por eso que, dejando de lado la pretensión de completitud - pues repasar todos los usos del concepto sería imposible- nos proponemos en esta sección tres objetivos, que organizaremos en torno a tres capítulos.

En primer lugar, buscamos dar cuenta sucintamente del estado actual de la discusión en torno a la estetización, no sólo, y no principalmente, entre los intérpretes de Benjamin, sino entre aquellos que, como él, se hayan comprometido con algún tipo de diagnóstico de la época de la que son testigos (Cap. 1: "El fenómeno de la estetización en la filosofía reciente”). En función, entonces, de delinear el espacio problemático, nos referiremos a tres grandes campos de significado entre los que se mueve el concepto, a saber, la estetización entendida como (a) embellecimiento o estilización, (b) búsqueda de la fascinación y (c) una forma específica de estructurar la experiencia.

En segundo lugar, como un antecedente relevante y a su vez como quien da forma a la tercera acepción del término, relacionándolo con la mirada distanciada que produce el régimen capitalista junto a la vida en las ciudades, dedicaremos un capítulo a la figura de Georg Simmel y al modo en que delineó, en sus incisivos ensayos, el problema de la estetización, al que Benjamin supo conferir, como sostendremos, densidad política (Cap. 2: "El motivo de la estetización en Georg Simmel").

En tercer lugar, y centralmente, presentaremos una interpretación de algunos textos de Benjamin para dar cuenta del alcance de su crítica de la mirada estetizante no sólo en torno a la relación entre el arte y la política, sino también como parte de su crítica al historicismo y a su forma de conceptualizar el pasado (Cap. 3: "El problema de la estetización en Walter Benjamin"). 


\title{
Capítulo 1
}

\section{El fenómeno de la estetización en la filosofía reciente}

\author{
Creer que "la belleza salvará al mundo" es una ilusión.
}

Gilles Lipovetsky y Jean Serroy, 2014, p. 49

\subsection{Introducción}

En un artículo sobre la ideología estética, Martin Jay recuerda que, desde que Walter Benjamin se refirió a la estetización de la política como un rasgo propio del nazismo en su célebre ensayo sobre "La obra de arte en la época de su reproductibilidad técnica", este concepto ha adquirido centralidad y autoridad en las discusiones sobre el fascismo y el totalitarismo (Jay, 2003, p. 71; Acosta, 2010, p. 54). En efecto, la alusión a una operación de estetización de la política y el análisis de algunos casos paradigmáticos de esta operación, como los documentales de Leni Riefenstahl ${ }^{5}$ o los dichos de Filippo Tommaso Marinetti ${ }^{6}$, terminaron

\footnotetext{
${ }^{5}$ Usamos aquí (y en otros lugares) la categoría de documental en sentido amplio, y a pesar de que referirse de esta manera a la obra de Riefenstahl fue cuestionado, por ejemplo, por Sontag. En su perspectiva, que se centra en el contexto de producción de la obra, sería incorrecto usar esta categoría para referirse a obras destinadas a la propaganda. En sus palabras: "Todo el que defienda las películas de Riefenstahl como documentales, si hemos de distinguir el documental de la propaganda, estará siendo ingenuo. En El triunfo de la voluntad, el documento (la imagen) no solo es el registro de la realidad, sino que es una razón de que la realidad se haya construido, y debe, a la postre, reemplazarla" (2007a, p. 92). También Gubern, en otros sentidos un marcado defensor de Riefenstahl, ha caracterizado a "El triunfo de la voluntad" como "un film documental sólo a medias" (p. 241), teniendo en cuenta que "se basó en el rodaje de unas ceremonias políticas cuidadosamente puestas en escena con vistas a su espectacularización en la pantalla" (2006, p. 252). Es importante, al referirnos a este film como documental, tener esto en cuenta, ya que la misma cineasta ha dado cuenta del modo en que "los preparativos del Congreso se hicieron en concierto con la preparación para la filmación, es decir, que el acontecimiento fue planeado no sólo como una espectacular reunión de masas, sino como un espectacular film de propaganda" (Riefenstahl, citada por Gubern, 2006, p. 253). Aun así, entendemos que no puede dejar de tenerse en cuenta, también, la historia de la recepción de la obra. En el caso de Riefenstahl, su obra logra una cierta independencia de su contexto de producción y pierde, en la historia de sus recepciones, la función de propaganda al punto de ser considerada una obra maestra del documental.

${ }^{6}$ Nos referimos a su tristemente célebre afirmación de que la guerra es bella, presente en su texto "Estética futurista de la guerra", publicado en la revista Stile Futurista en 1935, en el que sostiene que "la guerra es bella, ya que reúne en una sinfonía los tiroteos, los cañonazos, los altos el fuego, los perfumes y olores de la descomposición”.
} 
por adquirir una fuerza explicativa propia, como si el recurso a lo estético por parte de la política valiera por sí mismo para explicar los horrores totalitarios que marcaron el siglo.

Crítico de esta asunción apresurada, Jay se dedica, en el artículo, a operar una reconfiguración de este esquema interpretativo: en lugar de usar la estetización de la política para explicar otros fenómenos, se centra en este concepto y se pregunta qué implica, al fin y al cabo, estetizar la política (Jay, 1993) ${ }^{7}$. En su perspectiva y como recuerda Lutz Koepnick (1999), esclarecer qué significa, en el marco de la estetización de la política, el término “estética” sería el único camino posible para comprender por qué la extrapolación de lo estético al ámbito de la política resulta indeseable o peligrosa.

Ahora bien, además de los usos de la idea de "estetización de la política" para caracterizar un modo específico de operar políticamente, encontramos en la actualidad otros usos del concepto de estetización. En este capítulo, sin pretender desentrañar la compleja historia conceptual de la estetización, nos abocaremos entonces, en la línea de Jay, a delinear los contornos de una definición, aunque, a diferencia de Jay, incorporaremos no sólo la denuncia de una estetización de la política como rasgo característico del fascismo ${ }^{8}$, sino también algunos otros usos del término, como la estetización general de la existencia denunciada por Gianni Vattimo, la estetización de la vida que plantean Lipovetsky y Serroy y los debates sobre la estetización de las vivencias cotidianas que se dan en Alemania en la década del 90, fundamentalmente de la mano de Wolfgang Welsch y Gerhard Schulze ${ }^{9}$.

Incluiremos en esta cartografía, además de aquellos autores que explícitamente se refirieron al problema de la estetización, los aportes de autores que, sin utilizar el concepto,

\footnotetext{
${ }^{7}$ En una línea cercana a la de Jay, Lutz Koepnick ha sabido, en Walter Benjamin and the aesthetics of power (1999), alejarse de las interpretaciones apresuradas que identifican aproblemáticamente al nazismo con una cierta estética, como si el análisis de las estrategias estéticas que aquél supo, indudablemente, desplegar, fuera suficiente para comprender cabalmente un fenómeno tan complejo como el totalitarismo.

${ }^{8}$ En el Capítulo 3 de esta investigación, centrado en el problema de la estetización desde la perspectiva de Walter Benjamin, tendremos oportunidad de discutir específicamente este tema.

${ }^{9}$ Ulla Fix reconstruye que, en los 90, el concepto de estetización y la idea de que la estetización representaba algo así como un problema se convirtieron en parte del discurso público en Alemania (Fix, 2001, p. 36).
} 
parecen mentar el mismo tipo de proceso, en tanto "la idea parece más vieja que la acuñación del concepto" (Dziudzia, 2015, p. 12) ${ }^{10}$. Se ha argumentado, en este sentido (por ejemplo, en Galfione, 2014), que la atención en el peligro de la estetización se remontaría al mismo Platón, y cristalizaría en su célebre expulsión de los poetas en la República. Siguiendo esta lógica, la entera historia de las reflexiones sobre el arte y su rol en la sociedad tendrían algo que aportar a la historia conceptual de la estetización, y muy probablemente lo tengan. En nuestro caso, sin embargo, procuraremos hacer un recorte algo más específico.

A la hora de trabajar con un concepto como el de estetización es importante recordar que, como supo señalar muy acertadamente Corinna Dziudzia, la historia conceptual trabaja con conceptos clave [Schlüsselbegriffe], esto es, reconstruye la historia de determinados significados y discusiones que entiende como relevantes, accediendo a ellos por medio de determinados conceptos, y “en el caso de la estetización no se trata de uno de esos conceptos clave" (2015, p. 21). El concepto clave, al que refieren todos los intentos de dilucidar qué mienta el concepto de estetización es, como queda claro, el de estética, que carga a su vez con una historia conceptual plagada de debates. En nuestro caso, preferimos reivindicar la especificidad de la idea de estetización y de la potencialidad crítica que posee este concepto en tanto, como veremos, señala siempre una operación compleja y no sólo la presencia o la realización de lo estético, como rezaría una definición básica. El esclarecimiento o la problematización del motivo de la estetización, si bien se despliega siempre en estrecha cercanía con los debates sobre la estética o lo estético, no se limita a ellos, sino que exige un tratamiento propio que atienda a la densidad política de la historia de sus usos.

En ese marco, nos proponemos realizar aquí una cartografía de los usos de la idea de estetización con el objetivo de delinear el campo de debates en el marco del cual nos interesa

\footnotetext{
${ }^{10}$ Cabe mencionar en este punto, si bien no lo incluimos en esta presentación, el caso de Schiller, a quien tanto Kösser (2006) como Welsch y Pries (1991) colocan como un antecedente relevante en tanto se refirió, en sus Cartas sobre la educación estética del hombre, a la "bella apariencia" [der schöne Schein] (Kösser, p. 455). Sobre este texto, y su importancia para la historia de la estetización, recomendamos ver Melamed (2016).
} 
pensar los aportes de Benjamin. Para hacerlo, nos referiremos a tres grandes sentidos que ha adquirido el concepto de estetización, a saber, (a) la estetización como embellecimiento, ligada a procesos de estilización de las mercancías y en general del entorno, (b) la estetización como la búsqueda de generar fascinación, que opera en diagnósticos que la ligan a la puesta en escena, a la teatralización y al espectáculo, y (c) la estetización como una forma de organizar la experiencia, en la que el entorno se transfigura en mera imagen, y la apreciación o el disfrute estético se alza como la única forma de habérselas con el mundo. Esta distinción, cabe aclarar, responde a una pretensión analítica que, si bien da cuenta, a nuestro entender y de modo general, del panorama teórico que se abre en torno al concepto que nos ocupa, tiene también sus limitaciones. Como será claro en el desarrollo del capítulo, no todas las posiciones de las que nos ocupamos trabajan con uno solo de estos sentidos, y muchas veces los diagnósticos se resisten a esta sistematización. Aun así, creemos que en un sentido general y para los fines a los que se orienta esta investigación, esta cartografía resulta fructífera ${ }^{11}$. Un mapa, cabe recordar, no pretende configurar una representación fiel del terreno, sino funcionar, más bien, como una herramienta para su exploración.

El objetivo de realizar este recorrido será dar cuenta de la potencialidad crítica de la idea de estetización como un desarrollo teórico relevante y productivo, especialmente en la tercera acepción que, sin negar la importancia del embellecimiento y la espectacularización, permite dar cuenta de la acentuación de un modo despolitizado de relación con el mundo cuya denuncia es, creemos, el corazón del texto de Benjamin y una parte importante de su proyecto filosófico. Buscamos, a su vez, hacer especial hincapié en la relación de dicha denuncia con una preocupación que recorre toda su obra y que tiene por centro a la crisis de la experiencia que vislumbró en su tiempo y que encuentra ecos en nuestros días. En este sentido,

\footnotetext{
${ }^{11}$ Welsch (1996) ha emprendido un trabajo similar, en el que comienza dando cuenta de aspectos más superficiales del fenómeno (p. 2) y avanza hacia un diagnóstico más profundo, en el que nos centraremos, más adelante, en este mismo capítulo.
} 
compartimos con Koepnick la opinión de que "la obra de Benjamin puede aportar todavía a un análisis crítico de nuestra propia época, marcada por el entrecruzamiento cada vez mayor entre la cultura, la economía y la política" (Koepnick, 1999, p. 24). Especialmente, el diagnóstico de una estetización de la política, y la recuperación del sentido que dicho diagnóstico tuvo en el contexto de la obra de Benjamin, tiene algo que aportar a las discusiones actuales sobre la estetización como problema y puede ayudarnos a responder a la pregunta que arroja Kösser, a saber, “'hasta qué punto se puede ampliar la utilización del concepto de estetización, de modo que aún tenga sentido y proporcione información sobre un proceso específico?” (Kösser, 2006, p. 460).

\subsection{Una primera caracterización}

Antes de abocarnos a esclarecer los modos en que este concepto fue comprendido, y como punto de partida, resulta interesante remitirnos a la enciclopedia de estética Ästhetische Grundbegriffe. Historisches Wörterbuch in sieben Bänden en busca de un primer esclarecimiento conceptual. Allí, el concepto de estetización no cuenta, previsiblemente y como adelantamos, con una entrada propia, pero sí con un apartado dentro de la entrada “Ästhetik/ästhetisch" ["Estética/estético"]. En dicho marco y bajo la rúbrica "Ästhetisierung”, en el apartado a cargo de Karlheinz Barck, se lee:

\footnotetext{
'Estetización' no es un concepto reflexivo sino uno descriptivo, que se usa para caracterizar realidades según los criterios que señalan diferentes conceptos de estética y estético, o para indicar de manera prescriptiva vías y formas de realización de estos conceptos. (Barck, 2000, p. 314)
}

Cabe realizar aquí dos acotaciones. En primer lugar, resulta interesante el señalamiento sobre los diferentes conceptos de estética y estético. En efecto, "estetizar", en el sentido general 
de realizar lo estético en una realidad específica, esto es, de volver estético, será una acción de una cierta naturaleza si entendemos "estético" en su sentido originario de aisthesis -ligado a la percepción sensible- y algo muy diferente si limitamos lo "estético" a lo relativo al mundo del arte. A su vez, "estetizar" adquirirá un cariz completamente distinto si "estético" es comprendido en su acepción más popular en el lenguaje cotidiano, esto es, como ligado a la belleza de los cuerpos y las cosas y en general a la cosmética ${ }^{12}$. Cabe aclarar que esta significación múltiple, lejos de ser un obstáculo a sortear o un error que pueda corregirse mediante disquisiciones filológicas, es constitutiva del concepto: algo de aquel concepto de aisthesis permea el concepto mismo de estética en todos sus usos, en tanto, como menciona Gerda Haßler, "la significación pasada es siempre todavía una significación posible en el presente" (citada por Dziudzia, 2015, p. 19). ${ }^{13}$

Ahora bien $-\mathrm{y}$ en segundo lugar- cabe enfatizar que entre estética y estetización hay una distancia que señala ya la morfología del término pero que resulta significativa también a otros niveles. El concepto posee un carácter procesual que en alemán se señala mediante la adición de -sierung y que fue, en el marco de las utilizaciones que lo asocian a procesos sociales y culturales, acentuado por medio de la forma Ästhetisierungsprozesse, esto es, procesos de estetización (Barck, 2000, p. 315). En el caso de la idea de estetización, señala Kösser, lo que se mienta es "que algo, que originalmente no es estético, se vuelve estético; que algo que antes estaba en otro contexto es colocado en un contexto estético" (Kösser, 2006, p. 454) ${ }^{14}$. En otras

\footnotetext{
${ }^{12}$ Nos referimos aquí a las apariciones del término en el paisaje citadino, en la publicidad y en el lenguaje cotidiano: centros de estética, cirugía estética, etc.

${ }^{13}$ También Barck, en la entrada que citamos, da cuenta de cómo la ampliación o la restricción de aquello que se mienta en cada época con "estética" o "estético", además de ser una evidencia de la tensión entre el significado originario del término, que se resiste a desaparecer, y los intentos de delimitación de lo estético como una esfera separada, es un indicador potente de cambios sociales y políticos. En este contexto, la aparición del concepto de estetización es sintomática de un movimiento de "ampliación del alcance de la estética más allá del arte y las artes hacia otras áreas del conocimiento, la vida cotidiana, la política, la economía y la naturaleza" (Barck, 2000, p. 309). Fenves, por su parte, sostiene que el concepto de estética que está a la base de los escritos de Benjamin es el concepto de Baumgarten (2010, p. 81), en tanto ambos privilegian el estudio del aparato perceptivo humano.

${ }^{14} \mathrm{El}$ autor está tomando aquí la definición de Wolfgang Welsch, quien reaviva en el contexto alemán la discusión sobre la estetización en los años 90 (Kösser, 2006, p. 458).
} 
palabras, el esclarecimiento, si fuera posible, de los términos "estética" o "estético", no sería suficiente para dar cuenta de la especificidad de los procesos que se mientan cuando se habla de estetización. Más allá de lo meramente morfológico, y como defenderemos a lo largo de este capítulo, el concepto de estetización porta, a diferencia del concepto de estética, una potencialidad crítica en tanto no sólo describe un hecho, sino que advierte sobre un fenómeno social complejo. En este sentido, si bien puede resultar útil como primera aproximación conceptual, nos alejaremos de esta definición meramente descriptiva del término que proporciona Barck e intentaremos recuperar el carácter político de la estetización y el componente crítico que signa al concepto en sus usos filosóficos y, específicamente, en el uso benjaminiano.

En cuanto a la historia del concepto, se trata, según se indica en el texto de Barck, de un concepto joven: surgido en el siglo XIX en el marco de la estética del arte por el arte [l'art pour l'art], es incorporado a la reflexión filosófica por Friedrich Nietzsche en El nacimiento de la tragedia, de $1872^{15}$

Uno de los momentos clave para la consolidación del concepto, no obstante, llega en 1936, cuando, como es sabido y como desarrollaremos en el Capítulo 3 de esta sección, Walter Benjamin emplea este concepto en el célebre final de su ensayo sobre la obra de arte, en el marco de una denuncia política: oponiendo estetización y politización, propone responder a la estetización de la política en manos del fascismo con la politización del arte.

\footnotetext{
${ }^{15}$ En realidad, Nietzsche no utiliza el concepto mismo. La frase que cita Barck en su historización de los usos del concepto de estetización pertenece al "Ensayo de autocrítica" que el autor agrega a la obra en 1886 a modo de prefacio de la tercera edición. Allí, Nietzsche se refiere al modo en que "sólo como fenómeno estético está justificada la existencia del mundo" ["dass nur als ästhetisches Phänomen das Dasein der Welt gerechtfertigt ist”]. Un dato interesante acerca de esta utilización es que Benjamin recupera este fragmento en El origen del Trauerspiel alemán, de 1928 (Benjamin, 2006, p. 311), y lo hace críticamente, para decir que "se abre así el abismo del esteticismo [Der Abgrund des Ästhetizismus]" (Benjamin, 2006, p. 311; GS I 283). Volveremos sobre estas ideas en el capítulo 3. Para un análisis de la cuestión de la "bella apariencia" y la relación entre la filosofía y la estética en Nietzsche, ver Menke (2011, pp. 235 y ss.). y Bowie (1999). Para un estudio sobre el Ensayo de autocrítica, ver Berríos Guajardo (2014). Para algunas otras relaciones relevantes entre Nietzsche y Benjamin recomendamos ver Friedlander (2012, p. 122 y ss.).
} 
Ahora bien, entre aquella utilización por parte de Nietzsche en 1872 y la aparición en el escrito de Benjamin, un hito marca el pase del concepto a arenas políticas. En 1919, Carl Schmitt se refiere en Politische Romantik a una "estetización general de las áreas de la vida

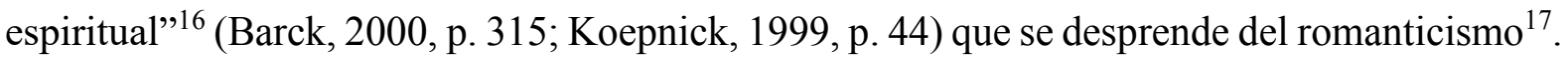
Al usar el término en este contexto, sostiene Barck, Schmitt de algún modo lo acuña a la vez que lo ancla en una cierta tradición: la que comienza con Friedrich Schiller y su transformación de la Crítica del juicio de Kant en la utopía de un estado estético donde política y estética se integran (Barck, 1999, pp. 110-111). En aquel texto (seguimos aquí la reconstrucción de Carlos Andrés Ramírez, 2009), Schmitt interpreta al romanticismo como una cierta metafísica, lo que "significa hacer de él una comprensión del mundo y, por tanto, elevar sus principios centrales a todas las esferas de la actividad humana" (Ramírez, 2009, p. 61), aun cuando sus principios centrales sean estéticos. En efecto,

sea la poesía o la música, de Novalis y Friedrich Hölderlin a Arthur Schopenhauer y Richard Wagner, podría hablarse de una operación romántica que consistió en postular un origen del arte al establecer sus vínculos con lo absoluto y, así, proporcionar un fundamento metafísico que en muchos casos condujo a su sacralización. Podría suponerse que el recurso al arte respondió a una búsqueda de consuelo ante el vacío metafísico pero, también, que se articuló como una crítica a la expansión de la racionalidad mecanizada propia del capitalismo. (Melamed, 2016b, p. 45)

En el caso del romanticismo político que titula el escrito de Schmitt:

\footnotetext{
${ }^{16}$ Como menciona Ramírez (2009), hay otro texto de Schmitt que resulta relevante para una reconstrucción del modo en que comprendió la estetización de la política. Se trata de la conferencia "La era de las neutralizaciones y las despolitizaciones", de 1929. Allí, Schmitt afirma: "El camino que va de la metafísica y la moral a la economía pasa por la estética, y la vía del consumo y el disfrute estéticos, todo lo sublime que se quiera, es la más segura para llegar a una 'economificación' general de la vida espiritual y a una constelación del espíritu que halle las categorías centrales de la existencia humana en la producción y el consumo” (Schmitt, citado por Ramírez, 2009, p. 60).

${ }^{17}$ Sobre el rol del concepto de estetización en el texto de Schmitt, sostiene Dziudzia que no es para nada central, aunque sí resulta relevante como antecedente de su utilización por parte de Benjamin (2015, pp. 14-15 nota 46).
} 
es la denominación schmittiana para caracterizar la global estetización de la acción política (...) y la constitución, a partir del posicionamiento de los conceptos estéticos como puntos nodales de una nueva formación discursiva, de un tipo de subjetividad centrado en la creatividad, las facultades expresivas y la ambivalencia emocional. (Ramírez, 2009, p. 68)

En dicho texto, asimismo -y esto será crucial para comprender el rol que el concepto adquiere en la filosofía de Benjamin-, Schmitt describe esta estetización general como el "mal histórico de la despolitización” [geschichtliches Übel der Entpolitisierung] (Barck, 2000, p. $315)^{18}$

Sin bien a partir del texto de Benjamin, y hasta nuestros días, el concepto ha adquirido matices diversos, es importante, al reconstruir su historia, recordar este componente político que lo signa. Son los textos de Schmitt y de Benjamin los que dotan al término de este potencial crítico que le era ajeno algunos años antes (como veremos en el caso de Simmel en el Capítulo 2 de esta sección) al asociarlo a la política en alguna medida como su opuesto y hacer hincapié en el carácter despolitizador de los procesos estetizantes. A partir de este giro -y siguiendo la reconstrucción de Barck (2000, p. 315)- el término comienza a ser utilizado no sólo para hacer referencia a cómo la realidad -y con ella los productos de consumo- son dotados de rasgos estéticos, sino más en general para referir a un rasgo propio de la cultura ligado a la banalidad o la superficialidad ${ }^{19}$. Siendo entonces la estética algo valorado, en términos generales, positivamente, su extrapolación a ámbitos que le son ajenos no siempre es juzgada de esta

\footnotetext{
${ }^{18}$ La relación entre Walter Benjamin y Carl Schmitt es por demás compleja. Como recuerda Taccetta (2015), "algunos comentadores se refieren a esta confluencia de pensamientos como una suerte de "debate" entre Benjamin y Schmitt. Este habría que establecerlo, de algún modo, en el largo periodo que va de 1925 a 1956, a partir de la cita de Teología política en El origen del drama barroco alemán, el currículum vítae de 1928 y la carta de Benjamin a Schmitt de diciembre de 1930, por un lado; y la referencia a Benjamin en el libro de 1956 Hamlet y Hécuba de Schmitt, por el otro" (p. 35, nota 7). En los últimos años, asimismo, esta relación se ha vuelto objeto de productivas investigaciones. Entre ellas, Agamben (2004), quien recurre al cruce entre los autores en su obra Estado de excepción, y Naishtat (2017a; 2008b), quien la trabaja con el fin de dar cuenta de la forma en que la teología opera en Benjamin como una cierta gramática del pensamiento.

${ }^{19}$ En Baudrillard, por ejemplo, la realidad es caracterizada como "transestética".
} 
manera: si bien dentro de las reflexiones sobre el arte tiene lugar una importante tradición en torno a la confianza en el poder del arte para introducir modificaciones deseables en la realidad, las operaciones que se nombran como de "estetización” son juzgadas por lo general de manera negativa, como encerrando un peligro. En efecto, el reconocimiento de la potencialidad del arte para moldear la sensibilidad del hombre nuevo, tal y como aparece, por ejemplo, en Herbert Marcuse, o la confianza en su capacidad de gestar "un mundo donde lo sensual, lo lúdico, lo sereno y lo bello lleguen a ser formas de existencia y, por tanto, la Forma de la sociedad misma" (Marcuse, 1969, p. 32), si bien defienden una cierta prelación de lo estético como deseable, no recurren al concepto de "estetización”. En este concepto, paulatinamente, se van sedimentando las significaciones negativas o peligrosas de un tipo de encuentro específico entre el arte y la sociedad.

Así lo entiende también Jay cuando, en relación a la estetización de la política, remarca que el peligro radica, no tanto en la extrapolación de criterios estéticos para juzgar hechos de naturaleza extra estética (la pobreza, una guerra o la explosión de una bomba), por problemática que pueda resultar esa extrapolación, sino en "el modo relajado en que los criterios no estéticos son deliberada y provocativamente excluidos de la consideración” (Jay, 2003, p. 73).

Ahora bien, qué tipo de criterios son los criterios estéticos y en qué medida impiden la incorporación o facilitan, al menos, la exclusión de consideraciones éticas, instrumentales, religiosas o de otros tipos, como enumera el mismo Jay (2003, p. 72), es algo que es necesario analizar más detalladamente. Un antecedente relevante en este sentido es Hermann Broch, en tanto ya en 1933, en sus consideraciones sobre el kitsch, se refiere al peligro que encarna el “esteta radical" (1970a, p. 13) en tanto "se considera autorizado para utilizar, y efectivamente utiliza sin ninguna clase de ponderación, cualquier medio con tal de alcanzar este tipo de belleza" (1970a, p. 13). El fenómeno mismo del kitsch es, en efecto, un proceso de estetización, en tanto su esencia "consiste en la substitución de la categoría ética con la categoría estética" 
(Broch, 1970a, p. 9), y en el culto a una "especie de religión de la belleza" (Broch, 1970b, p. 24) en el marco de una huida racional hacia lo irracional.

Y es que, como expone Gerard Vilar, "la estetización es un fenómeno sociológico amplio conocido desde hace décadas" (2012, p. 7). Este autor también sostiene que se trata de un fenómeno "mal estudiado en su conjunto" (2012, p. 7). Sin ir tan lejos, compartimos sin embargo la observación de que es más usual encontrar usos de este término en tramas problemáticas y diagnósticos variados que dar con trabajos de sistematización o historización de dichos usos. Así lo señala también Dziudzia, para quien “en general, las investigaciones actuales que utilizan el concepto de estetización se ocupan, más que de consideraciones histórico-conceptuales, de la idea de estetización como un fenómeno social contemporáneo que es necesario observar" (2015, p. 12). En este sentido, y si bien consideramos que dichas utilizaciones son valiosas, compartimos con Vilar la observación de que sería fructífero analizar qué quiere decir en cada caso, o al menos en algunos casos icónicos, estetización.

De mero embellecimiento a forma de relación con el mundo, pasando por la matriz de la fascinación, la estetización guarda, como intentaremos mostrar, la potencialidad de dar cuenta, no sólo de un fenómeno global que podríamos describir, sino también de un problema global que es necesario diagnosticar y cuyos peligros es necesario atender. Para hacerlo, nos proponemos a continuación dar cuenta de tres elementos propios de la experiencia estética (o de algunas experiencias estéticas concretas) cuya extrapolación a la vida política o al transcurrir de nuestra cotidianeidad es mentada en cada caso con el concepto de "estetización". Estos tres sentidos de estetización, lejos de agotar las posibilidades de comprensión, delimitación y definición de la estética o lo estético, buscan dar cuenta de lo específico de los procesos estetizantes, en los que el entorno -natural, político, social- es puesto en el lugar de obra y experimentado en una sola dimensión, en una operación que distorsiona algo de lo que era propio de la experiencia estética y lo desplaza a ámbitos no estéticos. 


\subsection{La estetización como estilización: la centralidad de la belleza}

Estamos totalmente atosigados en aras de la alegría de vivir. Sentirla es nuestra maldita obligación. El arte, el tráfico, el lujo... todo nos obliga.

Walter Benjamin, 2007g, p. 19

““Estetización’ es la búsqueda de lo agradable para el ojo”, sostiene Esther Leslie (2007, p. 164). En efecto, y si bien puede parecer un reduccionismo apresurado, en tanto el fenómeno es, como veremos, más complejo, la estetización "es entendida por lo general como embellecimiento [Verschönerung] de lo dado" (Kösser, 2006, p. 453). En este sentido, el concepto es utilizado para referir a fenómenos propios de la vida contemporánea en los que se privilegia un recorte o un ángulo de las cosas que revele una apariencia agradable, que muchas veces se conecta, más o menos directamente, con beneficios económicos o sociales. La belleza, como cualidad de los cuerpos o como rasgo de los bienes de consumo cuyo valor de uso se ve eclipsado por su apariencia irresistible, suele convertirse en un plus que cotiza en el mercado, cuando no en un capital en sí mismo. De la misma manera, podría decirse que industrias enteras como la de la moda o la decoración, pero también la del turismo, se alimentan del deseo de belleza que circula por la sociedad.

Ahora bien, en este sentido de estetización y como remarca Kösser (2006, p. 453), estético y bello son puestos como sinónimos, aun cuando esta equiparación pase por alto algunos hechos relevantes. Especialmente, habría que tener en cuenta toda una gama de búsquedas estéticas que escapan de la belleza o que la rechazan o la ignoran como criterio, mostrando que el arte no siempre embellece. Por otro lado, la utilización de medios artísticos, por ejemplo, por parte de la política, no siempre busca la belleza. En este sentido, deberíamos subsumir también bajo la idea de estetización, como propone Kösser, la presentación de algo bajo el aspecto de lo desagradable -como es el caso de la construcción de las imágenes de 
enemigos u oponentes políticos- o la escenificación de algún fenómeno como sublime o colosal (Kösser, 2006, p. 453).

En realidad, este sentido de estetización como embellecimiento no trabaja poniendo en el centro al arte, sino que se refiere a un embellecimiento de la realidad que usa medios y estrategias estéticos -no siempre artísticos- para ofrecer una apariencia agradable de los hechos, especialmente de aquellos que son percibidos típicamente como desagradables: guerras, violencia, muerte, sufrimiento (Kösser, 2006, p. 314). La idea de embellecimiento, entonces, por un lado, no incluye todo el arte (en tanto no todo el arte busca la belleza) y, por el otro, no incluye sólo el arte (en tanto no sólo el arte busca la belleza).

Este aspecto de la noción de estetización fue analizado, en los años 80 del siglo pasado, por Vattimo en el marco de su diagnóstico de una estetización general de la existencia. En efecto, en su trabajo el concepto de "estetización" no sólo no se refiere al arte, sino que trae aparejada la muerte del arte en cuanto tal. La belleza, para Vattimo, ha abandonado su antiguo emplazamiento en el seno de las obras de arte y ha cubierto al mundo con una apariencia agradable que se nos ofrece a la venta. "De hecho", sostiene el autor,

ya vivimos en la sociedad de la cultura de masas, en la que se puede hablar de estetización general de la vida en la medida en que los medios de difusión, que distribuyen información, cultura, entretenimiento, aunque siempre con los criterios generales de "belleza" (atractivo formal de los productos), han adquirido en la vida de cada cual un peso infinitamente mayor que en cualquier otra época del pasado. (Vattimo, 1987, p. 52)

En este mismo proceso, la muerte del arte se constata, según Vattimo, como la “constelación histórico-ontológica en la que nos movemos" (1987, p. 50), e implica que "el arte ya no existe como fenómeno específico (...) [E]1 arte está suprimido y hegelianamente superado 
en una estetización general de la existencia ${ }^{20 "}$ (1987, p. 50). Esta generalización de lo estético, posibilitada -como bien vio Benjamin- por las nuevas tecnologías, tiene como contracara la extinción de lo específicamente artístico o, en en los términos de Vattimo, la muerte del arte.

Los artistas reniegan de "todo elemento de deleite inmediato en la obra -el aspecto 'gastronómico' de la obra" (Vattimo, 1987, p. 53)-, y ponen en marcha un movimiento de huida de la belleza ${ }^{21}$. Como afirma Analía Melamed, "Vattimo retoma la tesis hegeliana de la muerte del arte, que se produce, dice, de un modo extrañamente pervertido: la muerte del arte es consecuencia, en la sociedad de la cultura de masas, de la estetización general de la vida" (2016, p. 6). ${ }^{22}$ Asimismo, e intentando escapar de la fetichización de la obra, el arte hace un movimiento hacia la desintegración de la misma como objeto (Melamed, 2016, p. 6), lo que culmina, en el arte contemporáneo, en la tendencia a la desobjetivización del arte que tendremos oportunidad de analizar en el Capítulo 7 de esta investigación en torno a la obra de Joseph Kosuth.

En torno a este modo de comprender la estetización, dos antecedentes resultan muy importantes: por un lado y como mencionamos, Broch supo percibir muy tempranamente la tendencia a privilegiar lo "agradable" a lo "bueno" (Broch, 1970a, p. 9), así como la profunda

\footnotetext{
${ }^{20}$ En la perspectiva de Vattimo, la estetización no tiene que ver solamente con la vida política, sino que es un fenómeno de mayor alcance. Además de hablar de estetización en el contexto de la muerte del arte, Vattimo se refiere también a "una estetización de la historia de la ciencia" por la que responsabiliza a Kuhn y que, en sus palabras, "en verdad corresponde a un fenómeno mucho más vasto del cual es al propio tiempo síntoma y manifestación final; se trata de lo que se puede llamar la "centralidad" de lo estético (experiencia estética, arte y fenómenos conexos) en la modernidad" (1987, p. 87).

${ }^{21}$ Aun cuando sus reflexiones tengan un tono muy asertivo, Vattimo es consciente de que "el discurso de la muerte del arte puede representar también una cómoda escapatoria, cómoda porque es sencilla y tranquilizadora en su redondez metafísica" (p. 54). En efecto, el filósofo italiano da cuenta de cómo el arte en un sentido tradicional sobrevive, en la medida en que "todavía existen teatros, salas de concierto, galerías de arte y artistas que producen obras, las cuales pueden situarse sin conflicto alguno dentro de estos marcos" (p. 54). Es por esto que elige, a medida que avanza en su argumento, referirse al ocaso del arte y no ya a su muerte.

22 También Sontag se hace eco de este escape del arte hacia un lugar diferente de la belleza. En "Un argumento sobre la belleza" recuerda: "parece inevitable que cuando, hace casi un siglo, las más prestigiosas comunidades artísticas dedicadas a las bellas artes se implicaron en proyectos de innovación drástica, la belleza estuviera en primera fila entre las nociones que era preciso desacreditar. La belleza no podía sino parecer un criterio conservador a los creadores y proclamadores de lo nuevo: Gertrude Stein sostenía que llamar bella a una obra de arte significa que está muerta" (2007, p. 23). En ese mismo ensayo, Sontag se refiere a la aparición del calificativo "interesante" en reemplazo de "bello" en el terreno de las artes: "¿Qué es interesante? Sobre todo, lo que antes no se ha considerado bello (o bueno)" (2007, p. 26). A su vez, da cuenta de cómo este nuevo criterio prefiere lo conflictivo, lo difícil y lo inarmónico, y arroja lo anteriormente "bello" al pozo de lo aburrido.
} 
estetización que implica la mirada nostálgica al pasado, en tanto "todo mundo histórico revivido nostálgicamente es 'bello"” (Broch, 1970a, p. 11). De todos modos, el enfoque de Broch, más allá de partir de este síntoma que es la búsqueda de lo agradable en tanto tranquilizador, avanza hacia una consideración más profunda de aquello que los procesos estetizantes implican en tanto configuradores de una experiencia limitada del mundo, a la que nos referiremos más adelante, por lo que escapa del eje del mero embellecimiento.

Por otro lado, la mirada optimista acerca de la estetización que representa en alguna medida Marcuse -aun cuando no utiliza el término-prefigura el motivo de la muerte del arte y su disolución en la sociedad. En "La nueva sensibilidad" se refiere a la posibilidad de que la realidad alcance una nueva forma, a saber, la de una sociedad libre, en virtud de la creación de un ethos estético, y sostiene que el nuevo rol del arte como "un factor integral en la configuración de la calidad y la 'apariencia' de la realidad (...) significaría la Aufhebung del arte" (1969, p. 38), en tanto fin de la escisión entre lo estético y lo real. Aun así, en la utopía de Marcuse esto significaría también "el fin de la unificación mercantil de negocios y belleza, explotación y placer" (1969, p. 38), lo que refleja que no tiene esperanzas puestas en el embellecimiento del mundo sino en un compromiso del arte con su rol político que podríamos acercar a la propuesta benjaminiana de politizar el arte.

Ya en el contexto alemán actual, dos de las figuras más relevantes para los debates sobre la estetización que tuvieron lugar en los años 90 han sido Schulze y Welsch ${ }^{23}$. De ellos, es el primero $^{24}$ el que aporta una perspectiva más asimilable a una concepción de la estetización como embellecimiento, si bien esta distinción tiene sólo un carácter propedéutico con vistas a organizar el campo problemático.

\footnotetext{
${ }^{23}$ Como menciona Dziudzia, los trabajos de estos dos autores lograron popularizar el concepto de estetización, que comenzó a utilizarse no sólo en trabajos académicos de diversas disciplinas (sociología, psicología, estudios culturales, crítica literaria), sino también en el lenguaje cotidiano (2015, p. 10).

${ }^{24}$ Nos referiremos a Welsch en otro apartado, dado que su interpretación de la estetización, si bien incluye un análisis de los procesos de embellecimiento, los excede.
} 
En su libro Die Erlebnisgesellschaft, publicado en 1992, Schulze traza los contornos de una sociedad marcada por valores estéticos, que no sólo exige que las cosas tengan una apariencia agradable, sino que estetiza también las vivencias personales. En este sentido, y tomando el ejemplo del mismo Schulze, no sólo el automóvil, como producto, debe ser bello, sino que debe proporcionarnos una vivencia agradable al manejarlo, y esto adquiere una importancia mayor que su practicidad y su capacidad de proporcionar una experiencia segura, por ejemplo ${ }^{25}$. La vivencia agradable, cabe aclarar, lo es también en la medida en que la imagen que el sujeto se forma de sí mismo conduciendo ese auto cumple un rol fundamental. La sociedad de las vivencias ${ }^{26}$, entonces, se estructura en torno a un cierto hedonismo consumista en el que la búsqueda del placer individual, en la forma de esta búsqueda de la belleza de las vivencias que conforman la vida cotidiana, pone en marcha un proceso de estetización de la vida que excede al individuo (Kösser, 2002, p. 459): dicho fenómeno, a su vez, lejos de limitarse a ciertos aspectos de la vida cotidiana o a la apariencia que algunos objetos de la misma adquieren, implica para Schulze "una estructuración de la sociedad en función de criterios estéticos" (Kösser, 2006, p. 459).

En la interpretación de Kösser, Schulze se alejaría, al destacar la importancia de las vivencias, de entender la estetización como mero embellecimiento. En efecto, algo en su análisis de cómo la búsqueda de las vivencias bellas impregna un modo de relacionarse con el entorno da cuenta de que no entiende el fenómeno de la estetización como afectando sólo las apariencias, sino que comprende el carácter estructural de su impacto en el modo de vivir ${ }^{27}$.

\footnotetext{
${ }^{25}$ Es importante en este punto recordar el artículo de Earnest Elmo Calkins, aparecido en 1927, "Beauty, the New Business Tool". Allí, a partir del ejemplo de la empresa Ford, el autor reflexiona sobre la importancia que adquiere la belleza para la colocación de un producto en el mercado, una vez que no quedan ya más innovaciones técnicas para mejorar la oferta de la competencia: cuando ya no se puede ofrecer un auto más rápido o más cómodo, se ofrece uno con las mismas características, pero dotado de un diseño irresistible.

${ }^{26} \mathrm{Si}$ bien en algunos casos se traduce Erlebnis como experiencia (quizá porque la traducción al inglés del libro lo titula The experience society), preferimos, por la importancia que la diferencia entre los vocablos alemanes Erlebnis y Erfahrung posee en el ámbito de los estudios benjaminianos, utilizar el término español "vivencia" que, junto con la fórmula "experiencia vivida", es la opción ya clásica para la traducción de Erlebnis.

${ }^{27}$ En una reseña que le dedica a Schulze, Honneth remite su perspectiva a la de Simmel, y en relación a la tesis de Schulze respecto a la estetización de la vida cotidiana, y si bien después le reconoce algún aporte, sostiene que
} 
No obstante, el eje está puesto en el carácter bello que adquiere el ideal de vida, y no en el modo de relación con el mundo propio del vínculo estetizante con él.

La comprensión de la estetización como (mero) embellecimiento, si bien da cuenta de un aspecto del fenómeno que no se puede ignorar, encierra quizá un peligro desde el punto de vista político: si reducimos el alcance del fenómeno de la estetización a esta vocación de embellecimiento, parece abrirse la posibilidad de una estetización buena, por así decirlo, que busca hacer del mundo un lugar más hermoso y potenciar el disfrute enriqueciendo nuestras experiencias.

Sin embargo, y como recuerda Susan Sontag, esta ansia de embellecimiento puede encubrir operaciones de otro alcance. En su célebre artículo "Fascinante fascismo", la autora da cuenta de esta complicidad entre la belleza y aquello que parece querer ocultar, haciendo foco en la obra de Leni Riefenstahl28: "La línea tomada por los defensores de Riefenstahl, que incluyen hoy a las voces más influyentes del establishment de la vanguardia fílmica, es que siempre estuvo interesada en la belleza" (Sontag, 2007a, p. 93) ${ }^{29}$.

El caso merece un poco más de análisis: en efecto, la misma Riefenstahl ha defendido su obra, y su propia biografía, apelando a la búsqueda de la belleza, en tanto ésta recorre su obra, teóricamente y a simple vista, más allá del nazismo, hasta sus fotografías de los Nuba "una tribu de estetas" (Sontag, 2007a, p. 96) ${ }^{30}$. Hacer hincapié en esta búsqueda estética,

este autor se limita a actualizar y aplicar al tiempo presente los análisis presentes ya en la obra de Simmel (Honneth, 1992, p. 522). Sin ir tan lejos, compartimos con Honneth la observación de que Schulze y Simmel están ambos interesados en dar cuenta de la íntima relación entre los procesos estetizantes y ciertos cambios en la forma de experimentar el mundo.

${ }^{28}$ Para una caracterización de la artista y un resumen de su biografía y su obra, recomendamos el texto de Sánchez Alarcón (1996).

${ }^{29}$ Una voz particularmente relevante entre los que han defendido a Riefenstahl es la de Roman Gubern. Al respecto puede consultarse su Prólogo a las memorias de Leni Riefenstahl y el capítulo VI de "La imagen pornográfica y otras perversiones ópticas", dedicado a "La imagen nazi". Allí, de todos modos, no duda en caracterizar a la artista como "la más ejemplar propagandista del cine nazi" (2006, p. 239). Asimismo, el capítulo es interesante en tanto el autor realiza una reconstrucción bastante exhaustiva de la gesta del aparato de propaganda nazi y de la consolidación de la estética que se convirtió en su insignia.

${ }^{30}$ A partir de la década del 50, Leni Riefenstahl, hasta entonces conocida por sus documentales de propaganda nazi, comenzó a dedicarse a la fotografía. Entre sus trabajos más celebrados se cuentan las fotografías que tomó de los miembros de la tribu Nuba en Sudán, que fueron reunidas en su libro The Last of the Nuba, de 1974. 
entonces, le permite a la artista dar un hilo a su obra que la presente, como observa Sontag, como "una fanática de la belleza y no una horrible propagandista" (2007a, p. 94). El modo en que Riefenstahl habla de su producción es, sin dudas, polémico:

sencillamente puedo decir que me siento espontáneamente atraída por todo lo que es bello. Sí: belleza, armonía. Y quizá este cuidado en la composición, esta aspiración a la forma sea, en efecto, algo muy alemán. Pero yo no conozco exactamente estas cosas. Vienen del inconsciente y no de mi conocimiento... ¿Qué quiere usted que añada yo? Todo lo que es puramente realista, «un pedazo de vida», que es mediocre, cotidiano, no me interesa... Estoy fascinada por lo que es hermoso, fuerte, saludable, lo que está vivo. Busco la armonía. Cuando se produce armonía, soy feliz. (Riefenstahl, citada por Sontag, 2007a, pp. 93-94)

La conexión que Riefenstahl realiza entre la belleza y la felicidad, por la vía de la armonía, sugiere una concepción del mundo que evita el conflicto y en la que el sufrimiento es ignorado en pos de una mirada que exalta (y muestra) solo aquello que le es agradable. El motivo no es nuevo: Nietzsche se ha referido a este carácter tranquilizador de la belleza de lo apolíneo. Como expone Menke, la diferencia entre lo apolíneo y lo dionisíaco funciona en dos niveles, a saber, como antagonismo de estilos y como señalamiento de dos maneras de relación con la apariencia estética. En cuanto al estilo -y si bien no se trata del nivel principal de la diferencia-, “se denomina 'dionisíaco’ un 'mundo de imágenes desigual e irregular' que al ‘alegre agrado' por lo bello le parece meramente feo, inarmónico y disonante” (Menke, 2011, p. 240). En efecto,

Nietzsche define lo apolíneo como 'el mundo de la bella apariencia' en el que lo dionisíaco ejerce sus efectos destructivos (...) y afirma así que la ley del arte que permite explicar lo particular del placer estético es su paso más allá de lo bello, su aniquilación del mundo visible de apariencia. (Menke, 2011, p. 240) 
En Riefenstahl, al menos si nos limitamos a su propia comprensión de su obra, lo dionisíaco no tiene lugar y el arte se enlaza, sin puentes, con la agradable belleza de lo armónico sin disonancias: una belleza "consoladora, no perturbadora" (Sontag, 2007b, p. 22).

En la perspectiva de Sontag, las palabras de la cineasta sobre su gusto por la belleza, lejos de funcionar para despegar su obra de los horrores del nazismo, la inculpan más aún, en la medida en que su búsqueda de la belleza es comprendida como parte de la estética nazi o en complicidad con ella. En nuestro caso, y estando la evaluación de la obra de la cineasta más allá de los objetivos de nuestra investigación, nos interesa atender al caso Riefenstahl justamente por el peso de sus propias alusiones a la belleza y, especialmente, al par estéticabelleza $^{31}$ y su relación con la felicidad. Específicamente, Riefenstahl intenta explicar su estetización del mundo en términos de una búsqueda de belleza y evita toda reflexión política sobre su propia práctica. Al hacerlo, se convierte en un ejemplo claro de por qué la estetización, y especialmente la estetización de la política, no puede ser comprendida como estando limitada al embellecimiento o la búsqueda de atractivos formales. Riefenstahl ha funcionado, indudablemente, como un engranaje en la maquinaria de la estetización de la política, y su gusto por la belleza (un gusto que, por otra parte, no resulta suficientemente específico, en tanto la belleza es casi por definición aquello que gusta) no logra explicar por qué. Asimismo, algo en la obra de Riefenstahl (en sus innovaciones técnicas, en su forma particular de mostrar) consigue que su obra exceda la propaganda y se destaque más allá de ella, por lo que comprenderla como una (mera) propagandista, en la línea de Sontag, limita las posibilidades de análisis de su obra. La exaltación de la belleza física y de los cuerpos atléticos es uno de los

\footnotetext{
${ }^{31}$ Uno de los temas clásicos en torno a la obra de Riefenstahl, o quizá más adecuadamente, unos de los temas para pensar los cuales su obra resulta paradigmática, es el de la autonomía del arte y, específicamente, la tensión que se produce a la hora de juzgar o historizar obras innovadoras y bien consideradas por la crítica que fueron, a su vez, instrumentos de propaganda política para regímenes autoritarios. Asimismo, su producción resulta interesante para reflexionar en torno al alcance de la obra más allá de las intenciones del autor o las condiciones de surgimiento.
} 
rasgos de la obra de Riefenstahl ${ }^{32}$, pero no el único. En primer lugar, es importante enfatizar que el criterio de belleza que la cineasta da por sentado está ya imbricado con el poder desde su definición: lo bello es para ella lo saludable, lo fuerte, lo vivo, lo perfecto ${ }^{33}$. La preferencia de lo triunfal/fuerte sobre lo vencido/débil es tan evidente como su reticencia a encontrar belleza en lo cotidiano, en lo dañado, en lo imperfecto y en aquellos "trozos de vida" que tantos artistas convierten en sus temas predilectos ${ }^{34}$.

Lo que nos interesa explorar aquí es en qué medida tanto los documentales de propaganda nazi como las fotografías de los miembros de la tribu Nuba pueden ser pensados como poniendo en marcha mecanismos de estetización, y no tanto por la decisión de retratar lo bello -con los exclusivos criterios de belleza de la $\operatorname{artista}^{35}-$, sino por la forma en que organizan el mundo. Como ampliaremos en los próximos apartados, la operación central de Riefenstahl, que le permite trabajar con materiales tan diversos como eventos fascistas, una tribu africana y, más adelante, el fondo del mar, es aquella que estructura la relación que entabla con dichos materiales, reduciéndolos a mera imagen. Imagen que, una vez constituida como tal, puede resultar bella o no, pero que requiere, en principio, ser organizada como una imagen y despojada de su espesor. El peligro no habita tanto en encontrar, como Riefenstahl,

\footnotetext{
${ }^{32}$ Sin ir más lejos, Olympia, el documental sobre los Juegos Olímpicos de Berlín de 1936, se divide en dos partes: Fest der Völker (Festival de los pueblos), y Fest der Schönheit (Festival de la belleza). La segunda parte, que se abre con secuencias de animales y plantas, se centra en mostrar la belleza de los cuerpos y los movimientos de los y las atletas (aunque a las mujeres se les dedica muchísimo menos tiempo que a los hombres), que no sólo aparecen compitiendo sino también relajándose, bañándose, en sesiones de masajes y riendo.

${ }^{33}$ Como menciona Sánchez Alarcón (1996, p. 305), ya en Das blaue Licht, la primera película de Riefenstahl como directora, de 1932, la ideología de la cineasta sale a la luz, a pesar de contar con el guión y la co-dirección de Bela Balazs, de ideología marxista. La película exalta y entrelaza la fuerza (como fuerza de la naturaleza), la juventud, la pureza y la belleza, dando cuenta del ideal que la cineasta seguiría replicando en sus documentales y fotografías hasta su muerte. Sontag, por su parte, extiende este análisis también a las películas en las que Riefenstahl actuó, la mayoría de las cuales fueron dirigidas por Arnold Fanck. Sobre ellas dice Sontag: "Consideradas, sin duda, como apolíticas cuando fueron hechas, estas películas parecen hoy, en retrospectiva, como lo ha indicado Siegfried Kracauer, una antología de sentimientos protonazis" (2007a, p. 84).

${ }^{34}$ Es el caso, en alguna medida, de Eugéne Atget, el fotógrafo favorito de Benjamin. Sobre él escribe en su "Pequeña historia de la fotografía" que buscó "lo apartado y lo desaparecido" (2007e, p. 394), que "se quitó la máscara y se dedicó a desmaquillar la realidad" (2007e, p. 393) y que "inició en su trabajo la liberación del objeto respecto del aura, cosa que es el mérito indudable de la escuela fotográfica reciente" (2007e, p. 393).

${ }^{35}$ Como resume bien Sontag: "Por lo general, se supone que la belleza es, casi de modo tautológico, una categoría 'estética', lo que la enfrenta, para muchos, directamente con la ética. Pero la belleza, aun la belleza en su modo amoral, nunca está desnuda. Y la atribución de belleza siempre está mezclada con valores morales" (2007b, p. 28).
} 
belleza en un desfile nazi, sino en convertir ese acontecimiento en algo que es juzgado con criterios estéticos y, más aún, afirmar que el trabajo del artista está ligado (y limitado) a una mirada que busca, muestra o construye belleza. De la misma manera, un documental que se centrara en la fealdad de las manifestaciones nazis o de las ceremonias y celebraciones de una tribu africana, esto es, en su falta de atractivo formal o de armonía, resultaría ridículo.

En las palabras de Leni Riefenstahl queda claro no sólo que tiende a encontrar belleza en diferentes objetos o situaciones, sino que no le interesa (al menos explícitamente, o quizá, concientemente) analizarlos de otra manera. Con sus ojos de esteta, Riefenstahl observa, estructura y presenta un mundo donde lo que importa son las formas, en tanto no le parece que relacionarse con esos fenómenos de otra manera le pueda ser exigido en tanto artista. A esta falencia, y a sus peligros, como veremos, se refiere Benjamin cuando exige la politización del arte y pide, no un arte pedagógico que enseñe sobre el bien y el mal, sino un arte que se relacione con el mundo de otra manera, y que deje de reducirlo a una mera imagen agradable frente a la cual nos quedamos boquiabiertos ${ }^{36}$. Lo que resta discutir (y que, en principio, no es central aquí) es si Riefenstahl —o acaso su obra- no logra, más allá de sus propios dichos, algo de esto. En efecto, tanto Triumph des Willens como Olympia $^{37}$ son hoy parte del archivo documental que consulta cualquiera que esté interesado en el nazismo, y han logrado despertar conciencia y hasta espanto frente al régimen que retratan. Al mostrar el nazismo, las películas logran de algún modo denunciarlo, más allá de las intenciones e intereses que les dieron

\footnotetext{
${ }^{36}$ En su Diario de Moscú, en el que escribe sus experiencias en dicha ciudad entre el 6 de diciembre de 1926 y el 1 de febrero de 1927, anota Benjamin sobre las organizaciones vanguardistas: "Lo revolucionario no les llega como experiencia, sino como un discurso" (2015c, p. 90). Esta afirmación resulta muy relevante, sobre todo, si se contextualiza: Benjamin está meditando, en Moscú, sobre la posibilidad de incorporarse al Partido Comunista Alemán.

${ }^{37}$ Si bien se trata de los dos documentales más recordados de Riefenstahl, y como recuerda Sontag, la artista realizó en total "cuatro películas con argumento no ficticio" (2007a, p. 85): "La victoria de la fe (Sieg des Glaubens, 1933), que celebraba el Primer Congreso del Partido Nacional Socialista desde que Hitler subió al poder (...) El triunfo de la Voluntad (Triumph des Willens, 1935) (...), después de lo cual hizo un documental breve (de dieciocho minutos), para el ejército, Día de la Libertad (Tag der Freiheit: Unsere Wehrmacht, 1935), que muestra la belleza de los soldados y de ser soldado para el Führer" (Sontag, 2007a, p. 86), y por último Olympia, en 1936 .
} 
lugar. ${ }^{38}$ En este sentido, ni la descripción que ella misma hace de su obra ni, por caso, la que propone Sontag, logran dar cuenta del lugar que ha adquirido en la historia del arte, en tanto la trascendencia de la obra de Riefenstahl no se limita ni a la belleza a la que ella misma se refiere, ni al régimen que la supo financiar y apoyar. Efectivamente, y si bien comprende su práctica como anclada en la búsqueda del atractivo formal, la artista innova en los medios técnicos heredados y logra dar cuenta de aspectos de la realidad -y, específicamente, del nazismo- que, sin su lente, no encontraban las condiciones que los hicieran visibles. Así, transformando los medios de producción con los que trabaja, la artista modifica también (como tendremos oportunidad de analizar en el Capítulo 3) las posibilidades del aparato perceptivo humano.

Más allá de las formas en que se pueda categorizar la obra de Riefenstahl, y de si es vista como una forma de estetización de la política o, incluso, como una extraña forma de politización del arte, tanto su obra como su forma de describirla resultan paradigmáticas para pensar la estetización como embellecimiento y las limitaciones de esta conceptualización. Y es que el concepto de estetización, o al menos el que permite recuperar Benjamin, contrariamente a lo que sostiene Barck, lejos de ser un concepto descriptivo tiene un potencial crítico que, al reducirlo a embellecimiento, se pierde.

No obstante, aun cuando no logra explicar la estetización en todo su alcance, esto es, como aparato que estructura una forma específica de relación con el entorno (e inhabilita otros), la comprensión del fenómeno de la estetización como embellecimiento y de los parámetros de belleza como prismas que han logrado estructurar nuestra cotidianidad resulta sin lugar a dudas relevante no sólo para realizar un diagnóstico de nuestra época, en la que

\footnotetext{
${ }^{38}$ Una reflexión de Benjamin sobre la fotografía puede ayudar a comprender aquí cómo la obra es capaz de despegarse de las intenciones del autor: "Pese a la destreza del fotógrafo y a la pose de su modelo, el observador se siente aquí impelido a ir rebuscando en estas imágenes la minúscula chispa de individualidad, de ese aquí y ahora con que la realidad ha abrasado la imagen; a identificar el lugar en el cual, en la concreción de aquel minuto pasado, lo futuro nos sigue hablando hoy, hasta el punto de que podemos descubrirlo retrospectivamente" (Benjamin, 2007e, p. 382).
} 
"las fachadas son cada vez más bonitas, las tiendas más animadas, las narices más perfectas" (Welsch, citado por Kösser, 2006, p. 458), sino también para comprender el diagnóstico benjaminiano de la estetización de la política.

En efecto, como desarrollaremos en el Capítulo 3, la belleza no es el componente principal en la conceptualización de Benjamin, para quien las profundas modificaciones en los modos de experimentar la realidad serán lo central, en tanto "la política estetizada redefine no sólo el canon de objetos bellos sino también cómo los vemos" (Koepnick, 1999, p. 12. El

enfatizado es nuestro). No obstante, la importancia que adquiere la belleza sí juega un rol en tanto forma parte de los cambios que el capital imprime, en el despuntar del siglo XX, a la vida en las ciudades, como tendremos oportunidad de ver en algunos textos de Simmel en el Capítulo 2 de esta investigación.

\subsection{La estetización como fascinación: la puesta en marcha del espectáculo}

El elemento de la belleza, su búsqueda, su contemplación y su apreciación, forma parte, sin lugar a dudas, de la forma en que el arte fue comprendido, pero no es, en todos los casos, lo que centralmente se pone en marcha en la experiencia estética. En este apartado, por lo tanto, nos centraremos en otro elemento de dicha experiencia que puede ser y ha sido extrapolado y distorsionado en experiencias de otro tipo -fundamentalmente políticas-: nos referimos a la fascinación.

Sin estar del todo separada de la belleza, en tanto puede ser producida por ella, la fascinación aparece, en el análisis de los textos que diagnostican diversas estetizaciones, como otro rasgo capaz de dar cuenta de aquello que se mienta cuando se habla de este tipo de procesos. En el caso paradigmático de la estetización de la política en el nazismo, "el nacionalsocialismo no ofrece solamente soluciones aparentes a los problemas (...) sino que 
también vende estas soluciones aparentes a través de la fascinación estética y así oculta el hecho de que los problemas no fueron realmente resueltos" (Kösser, 2006, p. 325. El enfatizado es nuestro).

Un ejemplo de este efecto, y de su potencia, es la experiencia que narra Ingmar Bergman de su participación en un evento nazi: "Yo no había visto jamás nada parecido a este estallido de fuerza incontenible. Grité como todos, alcé la mano como todos, rugí como todos, amé como todos" (citado por Gubern, 2006, p. 214). Si bien la experiencia es, en este caso, cercana a experiencias masivas de otras naturalezas (eventos religiosos, manifestaciones sociales, celebraciones), en el caso específico del nazismo el marco es la construcción de un espectáculo fascinante.

María del Rosario Acosta y Laura Quintana se refieren al nazismo como una política del espectáculo, y sostienen que "la estetización de la política también implicaría, entonces, la transformación de esta última en escenificación, en una puesta en obra para producir ciertos efectos sobre los espectadores" (2010, p. 56). El montaje de un espectáculo capaz de fascinar es una operación compleja que, lejos de valerse sólo del embellecimiento o el atractivo de lo que se presenta, trabaja con identificaciones y temores que le permiten movilizar a los espectadores hacia el consumo o el apoyo de un determinado producto, un régimen o una idea. En este sentido, la producción de la fascinación toma elementos no sólo del arte, sino también de otras áreas, típicamente de la religión o el mito (Abensour, 2010, p. 156 y ss). Y esta fascinación opera a su vez como un modelador de las masas, generando "un recogimiento en el que el individuo se siente absorbido, dominado, por la totalidad que contempla. Una totalidad que nos entrega el mundo desde una única mirada homogénea, desde la cual las diferencias de puntos de vista resultan superfluas, despreciables o eliminables" (Acosta y Quintana, 2010, p. 56). 
La estetización se entiende, en este contexto, como una operación que toma de la experiencia estética aquella potencia de cancelar la voluntad individual a la que se refería Schopenhauer en El mundo como voluntad y representación: en la contemplación de la obra se produce una inmersión tal que el propio yo es olvidado en pos de su fusión con ese absoluto que representa la obra ${ }^{39}$.

En el caso de la estetización de la política en manos del fascismo, el lugar de la obra lo ocupa el espectáculo ofrecido por el régimen, que las masas no sólo experimentan en tanto público sino, a su vez, siendo partícipes de esa representación, en tanto son de algún modo los figurantes en esa puesta en escena. La disolución del yo en la obra no puede ser más literal.

El concepto de "espectacularización" ha sido trabajado por Guy Debord, quien publicó en 1967 el célebre texto La sociedad del espectáculo. Allí, se refiere al espectáculo como “el momento histórico que nos contiene" (2002, p. 3) y lo define como la "tendencia a hacer ver por diferentes mediaciones especializadas el mundo que ya no es directamente aprehensible" (Debord, 2002, p. 4). Debord no parece tener en cuenta aquí que el mundo no solo resulta inaccesible hoy sin mediaciones técnicas, sino que lo fue siempre, en la medida en que no posee un núcleo duro que las mediaciones oculten, sino que se configura ya siempre a través de estas mediaciones. En su célebre escrito sobre la obra de arte, Benjamin, por su parte, lo deja ya claro:

Dentro de largos períodos históricos, junto con el modo de existencia de los colectivos humanos, se transforma también la manera de su percepción sensorial [die Art und Weise ihrer Sinneswahrnehmung]. El modo en que se organiza la

\footnotetext{
${ }^{39}$ La influencia de Schopenhauer puede verse, como ha sido ampliamente destacado (ver, por ejemplo, Ríos Rojas, 2015), en el ideal wagneriano de la obra de arte total. Asimismo, es relevante mencionar que, como sostiene Adorno, algo de este tipo de vínculo con la obra se persigue y se pone en marcha en la maquinaria hollywoodense por medio de la homogeneización de música, palabra e imagen. En "Ópera burguesa", Adorno se refiere a la "exagerada estilización de la existencia" (2006, p. 36) que se da en la opera, y muestra su asombro por "cuán pronto no pocos de los más abominables vicios de la actual industria cultural se anuncian en la ópera" (2006, p. 31). Sobre el ideal de la obra de arte total y la puesta en marcha de operaciones estetizantes en el nazismo, puede consultarse Stollmann (1978).
} 
percepción humana -el medio en que se lleva a cabo- no sólo está condicionado de manera natural sino también histórica. (Benjamin, 2015b, p. 31; GS I 478)

Como tendremos oportunidad de profundizar en otros capítulos, y como ya sabía Proust, la realidad se nos presenta mediada por "un instrumento de óptica, luego otro" (Proust, 1999, p. 330).

Volviendo a Debord, en su mirada "el espectáculo es el discurso ininterrumpido que el orden presente hace sobre sí mismo, su monólogo elogioso. Es el autorretrato del poder en la época de su gestión totalitaria de las condiciones de existencia” (2002, p. 5). La representación estética del poder, su aparecer no sólo embellecido en su autorretrato sino también fascinante e hipnótico recuerda al valor de culto tal y como lo comprendió Benjamin.

Sontag, como hemos visto, es muy crítica de la identificación de la estetización con un mero gusto por la belleza. Es así que, en su lectura de Riefenstahl, se encarga de delinear los contornos de la estetización en el contexto del fascismo en clave de fascinación. Retomando la tesis de Jean Genet -“el fascismo es teatro” (Sontag, 2007a, p. 113)-, analiza el poder simbólico del nazismo haciendo hincapié en su teatralización. En palabras de la autora: "La dramaturgia fascista se centra en transacciones orgiásticas entre fuerzas poderosas y sus títeres que, uniformados, se muestran en número cada vez mayor. Su coreografía alterna entre un movimiento incesante y una postura congelada, estática, viril” (Sontag, 2007a, p. 100).

Dramaturgia, coreografía, postura: el universo conceptual para hablar del fascismo viene del arte, y no casualmente. Como bien observa la autora, "lo interesante en la relación entre la política y el arte bajo el nacionalsocialismo no es que el arte fuera subordinado a las necesidades políticas (...), sino que la política se apropiara la retórica del arte” (2007a, p. 101).

Ya Joseph Goebbels se pronunció en 1933 respecto de que la política es “el arte más elevado y comprensivo que haya (...)”, y agregó: “y nosotros, los que modelamos la política 
alemana moderna nos sentimos los artistas. [Siendo] la tarea del arte y del artista formar, moldear, suprimir lo enfermo y dar libertad a lo sano" (citado por Sontag, 2007a, p. 101) ${ }^{40}$.

Sin embargo, el diagnóstico de Sontag ha sido objeto de críticas. Por ejemplo, Koepnick sugiere que la escritora queda atrapada en la lógica de la fascinación para dar cuenta de la relación entre estética y política en el fascismo, lo que termina simplificando su análisis. En sus palabras: "a diferencia de Benjamin, Sontag termina reduciendo la cuestión de la estética fascista a una cuestión de estilo, iconografía y representación; a un capítulo en el desarrollo del arte moderno que no guarda relación con transformaciones sociales más amplias" (Koepnick, 1999, p. 32). En efecto, falta en el análisis de Sontag una referencia más clara a las modificaciones profundas en la experiencia y, con ella, en el sujeto, que el aparato fascista aprovecha y potencia.

En el paradigmático caso de Goebbels, lo que sus palabras informan sobre la relación entre el arte y la política durante el nazismo es que no se trata de una mera apropiación. La política no toma prestados elementos del arte -la belleza, la forma de presentación, la puesta en escena- sino que comparte con él un elemento creador o formador. Si el arte es una manera de dar forma a lo amorfo, de ordenar lo caótico, de moldear una parte del mundo para que se adapte a ciertas normas o gustos, entonces la política, al menos en su versión fascista, es también un arte, y el político es el demiurgo que llevará a cabo la obra.

El elemento esencial en los dichos del ministro de propaganda de Hitler es entonces el carácter de aparato, el ejercicio de poder que implica la figura del autor en tanto creador de realidad, que recuerda a la figura del genio que sobrevuela algunas estéticas y que Benjamin

\footnotetext{
${ }^{40}$ No es la única referencia al carácter artístico del régimen nazi por parte del ministro de propaganda de Hitler. En otra oportunidad ha llegado a decir que "la obra entera del Führer es una prueba de espíritu artístico: su Estado es una construcción de verdadera medida clásica" (citado por Acosta y Quintana, 2010, p. 57). En efecto y como conviene recordar, "generalmente se piensa que el nacionalsocialismo sólo representa brutalidad y terror. Pero esto no es verdad. El nacionalsocialismo - más generalmente, el fascismo - también representa un ideal o, antes bien, unos ideales que persisten aún hoy bajo otras banderas: el ideal de la vida como arte, el culto a la belleza, el fetichismo del valor, la disolución de la enajenación y el sentimiento extático de la comunidad (...). Estos ideales están vivos y conmueven a muchas personas" (Sontag, 2007a, p. 105).
} 
criticará en 1936, en "La obra de arte en la época de su reproductibilidad técnica", junto con otras nociones tradicionales de la teoría del arte. El nazismo aprende del arte a distanciarse de aquello con lo que trata -las masas- y a estructurar la experiencia del mundo en los términos del artista y su obra, por un lado, y del espectador y la obra, por el otro. En el caso del nazismo, además y como mencionamos, obra y espectador son una y la misma masa. Es así que la masa "se ve reflejada en el espejo ${ }^{41}$ que el fascismo estéticamente configura: se trata del espejo que le permite contemplarse alienadamente en el espectáculo de su propia devastación" (Galende 2009, p. 176). En efecto, la consecuencia de la fascinación es la inacción, el quedarse boquiabierto: "la estetización de la política que se logra en el fascismo impide la reflexión al inducir a las masas a la contemplación del espectáculo y al explotar la fascinación con el ritual" (Andrade, 2009, p. 78).

Por otra parte, Giorgio Agamben, en su libro Profanaciones, ha dado cuenta del modo en que el espectáculo supo imponerse como forma de estructurar nuestra experiencia del mundo. Allí, propone llamar "espectáculo a la fase extrema del capitalismo que estamos viviendo, en la cual cada cosa es exhibida en su separación de sí misma" (2005, p. 107. Las cursivas son nuestras). Y precisamente en este elemento de la separación es que nos interesa centrarnos a continuación.

Si bien la puesta en escena es sin duda un aspecto fundamental de los procesos estetizantes, la fascinación y el embellecimiento que la signan revelan, analizadas en mayor detalle, un componente común que les es esencial y sin el cual no hay proceso de estetización posible: se trata de la operación de distanciamiento ${ }^{42}$ que la estetización requiere y que le otorga especificidad.

\footnotetext{
${ }^{41}$ Benjamin se refiere a los espejos en algunos textos de su Obra de los pasajes. Allí, en un fragmento de significado críptico, se pregunta: “¿Desde cuando se inicia la costumbre de enmarcar ricamente los espejos en sustitución de las pinturas?” (Benjamin, 2013, p. 857).

${ }^{42}$ El distanciamiento, aquí, se presenta como una operación ligada a la huida del encuentro con el mundo y al intento de ejercer control sobre aquello que aparece frente a nosotros, posicionándolo en el lugar de objeto mudo a descubrir o a juzgar. En otros contextos, y paradigmáticamente en la propuesta del teatro de Bertolt Brecht, la
} 
Debord mismo, al explicar el funcionamiento de la sociedad del espectáculo, se refiere a la distancia como un aspecto fundamental:

En el espectáculo una parte del mundo se representa ante el mundo y le es superior. El espectáculo no es más que el lenguaje común de esta separación. Lo que liga a los espectadores no es sino un vínculo irreversible con el mismo centro que sostiene su separación. El espectáculo reúne lo separado, pero lo reúne en tanto que separado. (Debord, 2002, p. 6)

También Koepnick sostiene que "el espectáculo fascista organiza la experiencia moderna para desplegar la percepción sensorial con el propósito de la coordinación política y la movilización total" (Koepnick, 1999, p. 12. El enfatizado es nuestro). Efectivamente, la separación y la distancia imprescindibles tanto para percibir la belleza cuanto para fascinarse ante algo dan cuenta de que para comprender la estetización como fenómeno hay que centrarse en el tipo de experiencia, esto es, en el modo de relación con el mundo, que la signa.

\subsection{La estetización como una forma de configuración de la experiencia: la centralidad}

\section{de la distancia}

Hemos alcanzado un grado de distancia permanente. Atisbo los placeres del alejamiento. Este pedacito de espacio me proporciona la intermitente pero útil emoción resultante de creer que comienzo y termino en mí misma.

Vivian Gornick, 2020, p. 189

\footnotetext{
operación de distanciamiento funciona en un sentido muy diferente. En efecto, y si bien en español se traducen de la misma manera, la palabra que utiliza Brecht es Verfremdungseffekt, que podría traducirse también como efecto de extrañamiento. Este efecto, a través de la interrupción, busca "entorpecer la ilusión del público y generar así un espacio para la toma de posición crítica y la reflexión" (Wizisla, 2007, p. 205). Benjamin, que fue amigo de Brecht y compartió proyectos con él, "concluyó once trabajos dedicados exclusiva o esencialmente a Brecht, de los cuales sin embargo solo cinco se publicaron en vida del autor" (Wizisla, 2007, p. 177).
} 
Tras detenernos en la acepción más general del concepto de estetización, que lo enhebra el embellecimiento, las apariencias y las formas, y revisar otra acepción posible que pone el énfasis en el carácter espectacular, impactante y fascinante que adquieren las obras en cierto tipo de experiencia estética y las cosas en la relación estetizante, nos centraremos ahora en una tercera posibilidad para comprender el concepto de estetización que es, a nuestro entender, la que mejor da cuenta de la denuncia benjaminiana. En este caso, y como adelantamos, la estetización aparece como una cierta relación con el entorno que se distancia de él y lo percibe como mera imagen, en una forma distorsionada de aquel desinterés que viera ya Kant en su clásico estudio.

Para demarcar esta forma de entender la estetización cabe comenzar con una aclaración: el distanciamiento que es propio de la relación estetizante no está separado de la belleza o de la fascinación, sino que puede ser la condición que las hace posibles. Como mencionamos, en el alegato de Riefenstahl, por ejemplo, su búsqueda de la belleza allí donde posa la vista -ya sea en un acto del nacionalsocialismo o en una danza de una tribu africanarequiere como condición que el entorno en el que la artista se mueve sea despojado de todo aquello que no es reducible a imagen: la tradición, las consecuencias políticas, las causas, el impacto de aquello que se observa en la vida de las personas y de la comunidad, los objetivos a los que sirve, la crueldad, y muchísimas cosas más. Ante el mundo con toda su complejidad, Leni Riefenstahl se permite ver belleza, lo que implica que se permite, en primer lugar, entablar con el entorno una relación de mera contemplación desinteresada. La belleza, entonces, deja de ser central: lo encuentre bello o no, es la pregunta por la belleza, la búsqueda de la belleza en tanto característica formal lo que indica una relación estetizante con el mundo. La artista se separa de aquello que observa, pierde la implicación práctica o vital con el fenómeno que la circunda, reduce el fenómeno a algo colocado frente a ella y, a partir de esa operación reduccionista, genera una imagen que se dispone a juzgar estéticamente. 
Con la fascinación puede ocurrir algo similar: lo que fascina puede aparecer separado del cuerpo propio, a la distancia del espectáculo ante el cual el individuo no puede más que quedarse boquiabierto, o puede presentarse como aquello en lo que el mismo yo se funde en una especie de embriaguez.

Conviene entonces aislar este elemento de la distancia y la falta de implicación significativa, en tanto habita en todas las comprensiones de la estetización sin estar siempre explícito. Al hacerlo, la estetización se revela como una forma de organización de la experiencia, como sostiene Koepnick en el marco de su análisis de la estetización de la política. En sus palabras:

Hablar de política estética no significa simplemente dar cuenta de una hábil estilización de la acción política - una organización seductora de signos, significados e iconografías públicos. En cambio, lo que hace la política estética es colonizar las estructuras de la experiencia moderna, emplear sentimientos populares y disciplinar la percepción sensorial. (1999, p. 4. El enfatizado es nuestro)

Este elemento de la estetización ha sido reconocido por algunos autores que han ido más allá del aspecto formal que adquiere aquello que se estetiza -la belleza-y del efecto que produce en quien lo observa -la fascinación- y han intentado dar cuenta de las profundas modificaciones en la estructura de la percepción y de la experiencia que este fenómeno pone en marcha.

Comenzaremos con el caso de Welsch, porque su posición tiende un puente entre la comprensión de la estetización como embellecimiento y esta otra conceptualización, que entendemos como más productiva, en la que la estetización modifica la forma de relación del hombre con el mundo en un sentido más radical. 
En un trabajo en colaboración, Christine Pries y Wolfgang Welsch se refieren a un “boom estético" (Welsch y Pries, 1991, p. 2) que se vislumbra en el mundo del consumo tanto como en el estilo personal y en la forma en que se modifica la apariencia de las ciudades, lo que podría enmarcarse dentro de la conceptualización de la estetización como embellecimiento. Aun así, dos aspectos de su posición resultan especialmente relevantes para superar dicha concepción: por un lado, la postulación de que la estetización no es un proceso que navegue la superficie, sino que impregna estructuras profundas de la realidad, en una medida tal que puede hablarse de un "giro estético" (Welsch y Pries, 1991, p. 3). En sus palabras:

Nuestro modo actual de percepción de la realidad es, tanto en la ciencia como en la vida cotidiana, fuertemente estético desde sus supuestos básicos. Se podría suponer que, tras el paradigma ontológico, el de la filosofía de la conciencia y el lingüístico, se abre camino hoy un cuarto: el paradigma estético. (1991, p. 3)

Con esta afirmación, Welsch y Pries alejan sus reflexiones decididamente de una comprensión de lo estético que lo limite a la apariencia de las cosas o la atención al detalle o al estilo, e incorporan en su idea de un giro estético el sedimento que en el concepto dejó la acepción originaria de aisthesis. De hecho, el mismo Welsch reconoce la incorporación de este sentido de estética en sus reflexiones cuando explícitamente aclara que "quisiera entender estética como aisthesis: como la tematización de todo tipo de percepciones, desde las sensoriales hasta las espirituales, cotidianas o sublimes, vitales o artísticas" (Welsch, 1991, p. 68. Enfatizado en el original).

En segundo lugar, resulta significativo en la perspectiva de Welsch el juego que elabora entre los conceptos de Ästhetisierung [estetización] y Anästhetisierung. Este último término es un neologismo que no encuentra equivalente en el español, pero cuya intención podría replicarse con el término "anestetización”, en tanto está formado por anestesia 
[Anästhesie] y estetización [Ästhetisierung]. Desde la perspectiva del autor, "la estetización parece ir acompañada de anestesia, cuyos efectos no son de naturaleza sensibilizadora sino anestésica" (Welsch y Pries, 1991, p. 3). El factor de lo anestésico permite vislumbrar la contracara de la fascinación y del culto a la belleza, esto es, la pasividad de un sujeto receptor cuyos nervios se encuentran atrofiados por la sobreestimulación a la que está sometido y por la velocidad de los cambios que experimenta.

El tratamiento del estado anestesiado que experimenta el sujeto, o el colectivo, en un contexto de estetización vuelve imposible perder de vista que el paradigma estético que -según Welsch- rige hoy nuestro modo de existencia no se limita a condiciones del mundo, sino que introduce cambios importantes en la subjetividad.

Este hecho fue observado muy tempranamente por Simmel y Benjamin, como tendremos oportunidad de discutir en los próximos capítulos, y no es ajeno a Heidegger. Sobre el caso de Simmel, David Frisby recuerda que fue el primero en fijarse en el fenómeno de la obtención de placer por medio de la observación de objetos desde un punto de vista contemplativo y desinteresado $^{43}$, sin inmersión directa (Frisby, 1992a, p. 151), y agrega que esa actitud distante y voyerista se encuentra en el paseante de las grandes ciudades, cuyos sentidos están sobreestimulados por la avalancha de nuevas perspectivas, impresiones y sensaciones que fluyen más allá de él (Frisby, en Featherstone, 2007, p. 70). Para Welsch y Pries, “en el mundo de la estimulación exagerada [Reizüberflutung], la anestetización se vuelve algo de importancia vital" (1991, p. 75) y se ve traducida en alguna medida en salud -o estrategia de supervivencia-, en tanto el sujeto no podría lidiar de otro modo con la cantidad de estímulos que se le imponen.

\footnotetext{
43 El motivo del desinterés, no obstante, tiene una larga tradición en la estética, que cristaliza de forma paradigmática en la tercera crítica kantiana. Allí, el desinterés es presentado como lo propio de la actitud estética y resulta fundamental para la defensa kantiana de la autonomía del campo estético. Frisby se refiere, en el pasaje citado, al modo en que objetos que no son considerados artísticos comienzan a ser contemplados y valorados con criterios importados del mundo del arte. Es justamente esta extrapolación lo que se enfatiza cuando se habla de "estetización".
} 
Con Welsch, al hecho de que la realidad tiene el carácter de una construcción (Welsch y Pries, 1991, p. 3) se le suma la observación de que la forma en que, de un tiempo a esta parte, constituimos la realidad tiene elementos tomados del mundo del arte. En sus palabras: "la realidad demuestra ser estética en todos los sentidos: en tanto está construida poéticamente, en tanto toma la forma de la ficción, y en tanto está constituida como imagen" (Welsch y Pries, 1991, p. 4. Las cursivas son nuestras).

El estudio de Koepnick también pone el eje en la relación con el entorno que se organiza tras aquello que Welsch denominaría el giro estético. El concepto de experiencia que -como analizaremos específicamente en los capítulos 4 y 5 - es uno de los pilares de la filosofía de Benjamin, resulta central para teorizar la estetización de la política, en la medida en que "la estetización fascista organiza la experiencia individual y colectiva" (Koepnick, 1999, p. 4) y pone en marcha "una domesticación sutil de las peculiares estructuras modernas de visión, percepción y experiencia. La organización de sensaciones auráticas en una cultura post aurática está en el centro mismo de la política estética” (1999, p. 5).

Ya en 2014, en un ensayo titulado La estetización del mundo. Vivir en la época del capitalismo artístico, Lipovetsky y Serroy usan el concepto que nos ocupa para describir las sociedades actuales en una línea que se acerca bastante a la de Welsch. La transestetización contemporánea es para ellos un régimen del capitalismo, y no por las cualidades sensibles de las obras del capital, sino porque las operaciones que lo caracterizan para la comunicación, elaboración y distribución de los bienes de consumo son propias de un modo de producción estético que no se centra sólo en la producción de cosas, sino que explora también la producción misma de subjetividades ${ }^{44}$. En palabras de los autores:

\footnotetext{
${ }^{44}$ Sobre el impacto de los procesos estetizantes en la subjetividad desde una perspectiva política resultan interesantes los aportes de Rebentisch (2012). Fundamentalmente, y como menciona Galfione "Rebentisch intenta redefinir el concepto de 'estetización' a los fines de rescatar los aspectos políticamente productivos de un tipo de comportamiento que había sido denostado por la tradición filosófica occidental” (2014, p. 241).
} 
Hablar de capitalismo artístico no significa privilegiar un interés creativo capaz de hacer retroceder los imperativos de comercialización y rentabilidad (...) El capitalismo artístico crea valor económico por el camino indirecto del valor estético y experiencial: se afirma como un sistema que concibe, produce y distribuye placer, sensaciones e ilusión. (2014, p. 64)

El capitalismo artístico al que se refieren se maneja con cuatro mandatos: embellecer, seducir, innovar y distraer. En algún punto, estas leyes de la nueva era del capital siguen el recorrido que planteamos en este capítulo en torno a las posibles interpretaciones del concepto de estetización, en tanto se relacionan con la belleza (embellecer), con la fascinación (seducir, innovar) y con un cierto adormecimiento o anestesia que podríamos identificar con la distracción en tanto torna al sujeto pasivo y poco crítico.

La estetización de la vida, según estos autores, habría comenzado en la segunda mitad del siglo XIX -el escenario del nacimiento de Simmel, Benjamin y Heidegger y de la publicación de los primeros textos de Simmel-. Las primeras manifestaciones de este fenómeno fueron, por un lado, "la integración y generalización del orden del estilo, la seducción y la emoción en los bienes destinados al consumo" (Lipovetsky y Serroy, 2014, p. 71) y, por el otro, el crecimiento económico de las industrias culturales y creativas y su transformación en empresas.

En cuanto a la actualidad, la caracterizan como una era de hiperconsumo estetizado, que constituye una fase del capitalismo artístico cuyo comienzo datan en los años 80 , en la que los consumidores buscan no sólo bienes sino también experiencias estéticas -hay un mercado de experiencias- y en la que se produce, y esto es fundamental, una mirada específica: la de la distancia.

En efecto, la producción de la mirada distanciada indica que la estetización, lejos de afectar meramente la apariencia o los modos de presentación de los productos, es la puesta en marcha de un modo específico de relación con el entorno que toma elementos del arte $-\mathrm{y}$, como 
veremos con Benjamin, del arte aurático- y que tiene como resultado la inhibición de la acción, en tanto coloca al sujeto o al colectivo en la posición de mero consumidor pasivo de imágenes y sensaciones.

El giro estético de Welsch y Pries, la política estética de Koepnick y el capitalismo artístico al que se refieren Lipovetsky y Serroy son, efectivamente, formas de indicar un cambio en los modos de organizar la experiencia, que quiere decir también organizar la propia subjetividad, como sostiene Rendueles cuando afirma que

en el capitalismo contemporáneo, el complemento o incluso el sustituto del éxito material es la construcción activa de un yo estéticamente admirable, la intensificación de la experiencia. Más que en empresarios de nosotros mismos, nos hemos transformado en artistas de nosotros mismos. (Rendueles, 2016, p. 24)

\subsection{Consideraciones finales}

Habiendo reseñado brevemente distintos modos en que el fenómeno de la estetización puede ser comprendido, resulta relevante afirmar que, si bien las referencias a la belleza y a formas míticas de puesta en escena logran dar cuenta de importantes modificaciones en nuestra experiencia, sólo el último sentido, que pone en el centro de la problemática la distancia y la falta de implicación con el mundo es, creemos, capaz de recuperar la potencialidad crítica del concepto de estetización.

Como mostraremos en los siguientes capítulos, este es el sentido que la estetización adquiere en el marco de la filosofía de Benjamin, y es por eso que su perspectiva es capaz de iluminar los debates actuales: entendiendo la configuración de la experiencia propia de la relación estetizante con el mundo como una forma de despolitización, en la medida en que coloca al mundo a una distancia tal que no permite su modificación, Benjamin supo pensar a la politización y la estetización como dos modos excluyentes de organizar la experiencia. 
La figura de Simmel, asimismo, resulta un antecedente relevante en la medida en que, antes que Benjamin, muestra cómo en el siglo XX - un siglo estructurado en torno a la economía dineraria- la distancia entre el hombre y el mundo se hace mayor, y no sólo en términos de una separación relativa a mediaciones (como el dinero), sino en la forma de una distancia configurada estéticamente que es la punta del iceberg de aquello que será conceptualizado, ya en la filosofía de Benjamin, como una crisis radical de la experiencia.

La dimensión de la estetización que queremos privilegiar en esta investigación es, en última instancia, la dimensión política, y no sólo en el sentido de una estetización de la política en tanto utilización del arte por parte del poder político -para representarse, legitimarse, adornarse o propagar sus metas (Kösser, 2006, p. 313)-, sino en un sentido más general: como sostiene Jaeho Kang, lo político en Benjamin está referido no meramente a cuestiones ideológicas o institucionales sino más bien a los modos de organizar la experiencia (Kang, 2014, p. 130). En este sentido, todo proceso estetizante, en tanto operación por medio de la cual el mundo se organiza para el sujeto de un modo específico, es un proceso político. 


\section{Capítulo 2}

\section{El motivo de la estetización en Georg Simmel}

Incluso lo más bajo, lo que es en sí lo más feo, puede ser puesto en un contexto de colores y formas, sentimientos y vivencias, que le otorguen un significado encantador.

Georg Simmel, 1992, p. 64

\subsection{Introducción}

Cuando se repasan, como lo hemos hecho en el primer capítulo de esta investigación, algunas de las obras que configuran una cierta bibliografía sobre el concepto de "estetización" (Kösser, 2006; Featherstone, 2007) no puede dejar de observarse la referencia a una figura que aparece insistentemente: la de Georg Simmel (1858-1918).

Agudo observador de la sociedad de su época y testigo de los cambios en los modos de vida que trajo consigo el nuevo siglo, Simmel resulta a su vez un antecedente relevante para comprender el diagnóstico benjaminiano de una crisis de la experiencia, y uno de los tantos y variados autores cuya influencia puede rastrearse en la obra del berlinés. Específicamente, sus observaciones acerca del acrecentamiento de la importancia de la dimensión estética en la vida cotidiana, y el modo en que este fenómeno aparece ligado, en su obra, a conceptos cercanos a la crisis de la experiencia tal y como aparece en Benjamin, lo convierten en un antecedente de gran relevancia para nuestra investigación (Rehberg, 2018, p. 570; Böhringer, 2018, p. 851).

Las obras de Simmel y de Benjamin se conectan por motivos que van desde una marcada amplitud temática y de enfoque hasta una cierta capacidad de abrir lo no explorado trabajando con formatos que habilitan mayor plasticidad, como el ensayo y toda una gama de 
diferentes tipos de textos breves ${ }^{45}$ que caracterizan la obra de ambos y su estilo, en el que tanto se ha insistido. Resulta tentador, más allá de los "temas" o del "contenido" de sus reflexiones, acercar a estos dos pensadores por este último factor, a saber, el estilo, especialmente por su manejo del ensayo (género al que también se volcó Heidegger, como veremos en el capítulo 6), como el género filosófico con el que vuelven posible abordar temas tradicionalmente ajenos a la filosofía y tan disímiles entre sí como la comida, las exposiciones universales, la prostitución, la moda, el juego infantil o el paisaje. Esta tentación, no obstante, olvida los riesgos de una caída en el dualismo simple entre forma y contenido que no hace justicia a sus aportes: en su obra, contenido y forma se relacionan dialécticamente, acercando a ambos autores en función del modo en que fueron capaces de atender a las partes menos atendidas de nuestro entorno y echar, sobre ellas, chispas que las iluminen y las hagan, al menos por lo que dura un destello, dignas de disciplinas que las tuvieron históricamente fuera de su agenda.

David Frisby, en su ya clásico estudio Fragments of modernity, enfatiza este rasgo imposible de pensar simplemente como estilo, pero tampoco limitable a mero tema o contenido, cuando afirma, constelando a Benjamin y Simmel con Kracauer, que

lo que distingue las investigaciones de los tres autores sobre la modernidad y sobre la naturaleza específica de la experiencia de la vida moderna, es que no parten de un análisis de la sociedad en su conjunto ni de un análisis estructural o institucional (2013, p. 5),

sino que "parten de los aparentes fragmentos de la realidad social" (2013, p. 5). Hay, en efecto, un análisis de la superficie del mundo en contra de la tradicional búsqueda de la profundidad,

\footnotetext{
${ }^{45}$ Simmel escribió textos de naturaleza más aforística, no argumentativos, a los que llamó Momentbilder (Frisby, 2013, p. 5) cercanos a lo que en el caso de Benjamin fue llamado imágenes de pensamiento [Denkbilder].
} 
que Simmel y Benjamin comparten y que puede ponerse en diálogo con desarrollos posteriores como los de Žižek, Deleuze y Fujita Hirose ${ }^{46}$.

José Castillo, al referirse a la forma de escritura de Simmel, presta especial atención al modo en que fue motivo de halagos y críticas, y a veces de una forma curiosa de halagar criticando: las referencias a sus "encantadoras observaciones" (Castillo, 1998, p. 312) y a sus "brillantes intuiciones" (Castillo, 1998, p. 312) señalan una supuesta "incapacidad de Simmel para fundar una genuina ciencia de la sociedad humana" (Castillo, 1998, p. 312). Lo mismo sucede o ha sucedido -antes de la aparición de estudios benjaminianos más filológicamente orientados, y de especialistas en su figura y su obra- con Benjamin: pensador inclasificable, excéntrico, ensayístico, literario, la potencia de su pensamiento se ha visto diluida por esta forma de clasificarlo, como si sus ideas valieran por excéntricas. Si no es sistemático, si el estilo no es duro, si no cuesta leerlo y más aún si la experiencia de la lectura resulta placentera, algo de la cientificidad o del rigor parece perderse. Este fenómeno no es, en sí mismo, ajeno al tema de la estetización: Castillo da cuenta de que un contemporáneo de Simmel, "FrischeisenKöhler (...) fascinado por la maestría del estilo simmeliano, llega a calificarla de obstáculo para la comprensión de su trabajo sociológico" (1998, p. 312).

Simmel, entonces, contribuyó al desarrollo de la filosofía, de la sociología (en cuyo seno es más reconocido) y de la reflexión sobre el arte con una prolífica producción que no se agota en libros o cursos, sino que desborda en ensayos y textos breves que resultan, desde el presente, testimonios invaluables de una época que guarda con la nuestra una relación de parecido al menos inquietante.

\footnotetext{
${ }^{46}$ Nos referimos a operaciones como la que permite el concepto de cuerpo sin órganos de Deleuze, que puede ser comprendido como parte de un gesto filosófico más amplio, que Fujita Hirose comparte: intentar escapar de la profundidad introspectiva del sujeto que la filosofía ha heredado de su tradición, huyendo de esa hondura con la vista puesta sobre la superficie, para experimentar su potencialidad propia, siguiendo la intuición de que "la superficie es infinitamente más profunda que la profundidad" (Fujita Hirose, 2014, p. 70).
} 
La relación entre Benjamin y Simmel, y especialmente la influencia del último sobre el primero, ha sido desde siempre atendida, aun cuando Benjamin supo ser muy crítico de algunas ideas de Simmel, fundamentalmente en torno a la historia ${ }^{47}$. Como es sabido, y fundamentalmente antes del auge de los estudios propiamente benjaminianos, Benjamin aparecía por lo general en constelaciones con otros autores y, en tanto su propio enfoque es difícil de encasillar y no pertenece a una tradición de pensamiento clara, estas constelaciones han operado, en alguna medida, como esquemas interpretativos de su obra: hay, entonces, un Benjamin que pertenece a la escuela de Frankfurt, uno marxista que dialoga con Brecht y Asja Lacis, un Benjamin cuya relación con la tradición del judaísmo es acentuada a partir de sus intensos intercambios con Sholem, y se podría seguir. Frisby, por su parte, constela a Benjamin con Kracauer y Simmel y recurriremos a sus trabajos, por eso, como antecedentes relevantes para este capítulo. En esta línea, pero reclamando a Benjamin más fuertemente para su campo disciplinar, Ann T. Martínez piensa al berlinés como un sociólogo en la senda de Simmel (1984, p. 115), lo que resulta curioso sólo unos años después, cuando con los estudios sobre Benjamin

\footnotetext{
${ }^{47}$ En una carta a Gershom Scholem de diciembre de 1917, Benjamin se refiere muy críticamente a "Das Problem der historischen Zeit", texto de una conferencia de Simmel. Sobre él escribe Benjamin: "Hace algún tiempo leí 'El problema del tiempo histórico' de Simmel, un elaborado lamentable [ein ganz jämmerliches Elaborat] que, con muchas contorsiones del pensamiento, expresa las cosas más ridículas de una forma incomprensible"] (GB, p. 162). La carta de Benjamin se centra, si bien posee reflexiones y referencias varias, en la cuestión de la historia, en el marco de las lecturas del propio Benjamin para su proyecto, finalmente no realizado, de una tesis doctoral sobre el concepto de "tarea infinita" en la filosofía kantiana de la historia. Comienza con algunas reflexiones sobre la filosofía kantiana de la historia, menciona luego la lectura del texto de Simmel, y termina mencionando la lectura de "La révolte des anges" de Anatole France, texto que recibe una crítica muy positiva de su parte. Para un análisis más pormenorizado de este intercambio, ver Fenves (2012). Si bien no nos centraremos en la relación entre Benjamin y Simmel en torno a la problematización del tiempo histórico, cabe reponer brevemente algunas ideas sobre la historia que Simmel expone allí. En efecto, comienza afirmando que el objeto de la historia es la imagen teórica de lo ocurrido [theoretischen Gebildes das Geschehene] apartada de lo presente y lo futuro [abgehoben von dem Gegenwärtigen wie von dem Zukünftigen], y afirma que uno de los problemas teóricos de la historia es la conceptualización del tiempo. Asimismo, sostiene que un contenido de la realidad se convierte en histórico cuando logra ser fijado temporalmente (Simmel, GA XV, p. 289) y que el tiempo sería, a su vez, sólo una relación entre los contenidos históricos (Simmel, GA XV, p. 292), que estructuramos en torno a unidades de sentido temporales, mientras que la totalidad de la historia sería "libre de tiempo" [Zeitfrei]. Luego avanza hacia una reflexión sobre la individuación de estos contenidos históricos y sostiene que, mientras que dicha individuación se supo buscar en el carácter único de los acontecimientos, se haya en realidad en su rol dentro del curso de los hechos en un espacio determinado de tiempo (es decir, de define de manera relacional). Otra de las tesis que sostiene es que mientras que los acontecimientos son, en su sucederse, continuos, la historia no lo es, en tanto la imagen histórica es una construcción (Simmel, GA XV, p. 299), dentro de la cual conceptualizamos lo ocurrido como determinados "acontecimientos" [Ereignisse]. Por último, critica la visión atomista del mundo [die atomische Weltanschauung], por no poder explicar cómo se convierte lo acontecido en historia.
} 
ya más establecidos en el seno de las academias, otros autores (por ejemplo, Jameson, 1999; Meyer, 2018) invierten esta relación y piensan en Simmel como un predecesor sociológico de Benjamin.

Hans-Peter Müller (2018) sostiene que ni Benjamin, ni Lukács ni Heidegger, entre otros, podrían haber desarrollado su obra como lo hicieron si no fuera por la influencia de los escritos de Simmel (p. 13). Werner Jung coloca a Benjamin en el grupo de los "discípulos críticos” (2016, p. 110) de Simmel, junto con Bloch, Lukács, Kracauer y Adorno, y lo mismo hace Kang, cuando se refiere a los análisis sociológicos de Simmel sobre la cultura de la mercancía y la vida urbana contemporánea como las bases que hicieron posibles las reflexiones benjaminianas sobre la experiencia y sus modificaciones (2014, p. 7). Naishtat, por su parte, observa que la cierta "semiótica materialista" de Benjamin "remonta en su forma plástica a Georg Simmel, verdadero ancestro de este esquema interpretativo, con el que Benjamin enmienda a la tradición marxiana" (2011b, p. 262) ${ }^{48}$. Malika Maskarinec (2018) pone el foco en el concepto benjaminiano de aura, central en sus reflexiones sobre el arte, y sostiene que tendría su origen en la forma en que Simmel se refiere a la distancia que funda, entre la obra y el observador, el marco [Rahmen], y Hansen sostiene, en la misma línea, que la idea de que la distancia es constitutiva del arte autónomo encuentra su raíz en las ideas de Simmel (Hansen, 2007, p. 353).

En este sentido resulta valioso también el aporte de Uwe Steiner, quien en su introducción al pensamiento de Benjamin se refiere, entre otros mapas posibles, al que sitúa a Benjamin en la tradición alemana de los estudios de la cultura [Kulturwissenschaft], con Herder, Nietzsche, Freud, Aby Warburg y, por supuesto, Simmel (2010, p. 183). Denis

\footnotetext{
48 También Vargas (2015) en su "Comentario a 'Capitalismo como religión' de Walter Benjamin" da cuenta del impacto de las reflexiones simmelianas sobre el dinero en su obra.
} 
Thouard, por su parte, sostiene que la Kulturkritik de Benjamin y Adorno le debe directamente su existencia como ámbito filosófico a los esfuerzos intelectuales de Simmel (2018, p. 422).

El propio Benjamin se refiere a Simmel muchas veces: en una de las versiones de su currículum menciona sus clases, a las que asistiera en Berlín en 1912 (GS VI 215) ${ }^{49}$, y en su diario de viaje del verano de 1911 reporta estar leyendo un texto suyo, "Die Religion" (GS VI $248)^{50}$

En nuestro caso, nos interesa la perspectiva de Simmel en tanto arroja luz sobre una instancia embrionaria del fenómeno que Benjamin denunciará en los años 30, a saber, la estetización de la política como manifestación más extrema de la pobreza de experiencia en la que se ve sumido el hombre en la primera mitad del siglo $X X$. Intentaremos mostrar que en Simmel, y desde él en una cierta tradición que ha pensado este problema y en la que la figura de Benjamin es fundamental, la estetización se comprende como un modo de organizar la experiencia que toma elementos de la experiencia estética.

Las observaciones de Simmel sobre las modificaciones en el modo de vida que caracterizan el comienzo del siglo XX europeo son fundamentales para entender el sentido de la idea de estetización que Benjamin presenta en su célebre escrito "La obra de arte en la época de su reproductibilidad técnica" y que, como proponemos interpretar, atraviesa sin ser nombrado una parte importante de su obra. Como testigo del comienzo del siglo, y como el autor que "hizo, como nunca antes, de la cultura, sus conceptos y sus fenómenos el objeto de la reflexión filosófica" (Steiner, 2010, p. 25), Simmel ofrece, no cualquier panorama del comienzo del siglo XX, sino el de un pensador que se ocupó de buscar los modos apropiados

\footnotetext{
49 Además, como menciona Leslie, Benjamin realizó también un seminario sobre la filosofía de la historia de Simmel dictado por Ernst Troeltsch (2007, p. 45).

${ }^{50}$ En una carta a Scholem de 1917 (GB 162), Benjamin refiere haber leído "Das Problem der historischen Zeit [El problema del tiempo histórico]", de Simmel, texto que critica muy duramente. Nos referiremos a su relación en el terreno del pensamiento sobre la historia en el capítulo 6 de esta investigación, en el marco del triángulo que sus reflexiones forman con las de Martin Heidegger.
} 
para teorizar, pero también para señalar, para mostrar, para dar cuenta de las crisis y las reconfiguraciones que marcaron el derrotero de la experiencia humana del mundo.

Ahora bien, para abordar la cuestión de la estetización en los escritos de Simmel hay que tener en cuenta algunos datos y sortear algunas dificultades. En primer lugar, es necesario destacar que si bien, como mencionamos, resulta en alguna medida el precursor de las investigaciones sobre la estetización, Simmel está lejos de usar asiduamente este término (Ästhetisierung). De hecho, según Kösser, "Simmel describe ya en el siglo XIX el proceso de estetización en diferentes contextos, sin utilizar el concepto" (Kösser, 2006, p. 455).

Si bien ciertamente el término no forma parte de la red conceptual con la que Simmel trabaja $^{51}$, y en este sentido la observación resulta válida, cabe mencionar que el autor lo emplea al menos una vez, en "Sociología de la comida", de 1910. Volveremos sobre este texto en breve, pero nos interesa centrarnos, en primer lugar, en este hecho por demás llamativo, en tanto cabe preguntarse por qué, dado que casi no utiliza el término, en gran parte de los trabajos académicos que rastrean la historia de la idea de estetización, Simmel aparece como un antecedente de gran importancia. En efecto, para algunos intérpretes, como Mike Featherstone, Simmel puede ser leído como anticipando

la forma en que el paisaje urbano se ha estetizado y encantado a través de la arquitectura, la cartelera, los escaparates, anuncios, paquetes, letreros de las calles, etc., y a través de las personas que usan, en diversos grados, ropa de moda, peinados, maquillaje, o que se mueven, o sostienen sus cuerpos, en formas particularmente estilizadas. (Featherstone, 2007, p. 75)

La respuesta a este interrogante, entendemos, está en aquellas observaciones de Simmel que lograron abrir un cierto campo de estudio en torno a la relación entre la estética y la

\footnotetext{
${ }^{51}$ Algunos de los términos que Simmel emplea y que están emparentados con la idea de estetización son "Stilisierung" y "Schaufenster-Qualität".
} 
sociedad. En efecto, en consonancia con los desarrollos sociológicos de su época, y como menciona Barbara Aulinger (2017), el enfoque que Simmel imprimió al estudio del arte se diferenció del tipicamente estético y de la teoría del arte en las preguntas que supo formular: "La pregunta por la belleza fue reemplazada por preguntas nuevas: ¿cómo se crean los estilos? ¿hay un desarrollo del arte? ¿cómo está localizado en la sociedad?” (2017, p. 101) $)^{52}$. Se trata, en efecto, de preguntas que sientan las bases para la configuración de lo que hoy se conoce como sociología del arte o estudios sociales del arte ${ }^{53}$. Sin embargo, se trata también de preguntas que indican un camino para la investigación filosófica, en tanto abordan uno de los temas más clásicos de la filosofía, a saber, el de la experiencia, en tanto concepto que ha articulado tradicionalmente las teorizaciones sobre la relación del hombre con el mundo.

En nuestro caso, nos interesa centrarnos en cómo, al intentar comprender el fenómeno del arte como un fenómeno social complejo, Simmel hizo mucho más, logrando entrever algunos rasgos de la complejidad de nuestra experiencia del mundo a través del prisma que le ofreció el arte. Así, Simmel resulta un antecedente importante para la tematización de la estetización en tanto fue capaz de reconocer una dimensión estética en aspectos de la vida que suponían ser, en principio, ajenos al arte. En palabras de Frisby: "Simmel extiende, en efecto, dramáticamente el análisis del mundo cotidiano de la circulación (en la metrópolis) y del intercambio (en la economía monetaria) a través de revelar su dimensión estética” (Frisby, 1992a, p. 143).

\footnotetext{
${ }^{52}$ Como menciona la autora, y aunque la Sociología del arte, como disciplina, es posterior a la muerte de Simmel, Simmel puede ser considerado un precursor de los Estudios sociales del arte. Él mismo, consciente de sus aportes a la disciplina y del modo en que corre sus límites, escribe ya en 1899: "Mi sociología es una especialidad bien especial, para la cual no hay en Alemania otro representante más que yo mismo" (citado en Aulinger, 2017, 101. La cita es de GSG 11: 892). Benjamin también es un autor que fue considerado precursor de la Sociología del arte. Ver, al respecto, Hieber (2017).

53 Para una introducción a la sociología del arte como campo de estudios, recomendamos consultar Capasso, Bugnone y Fernández (Coords.) (2020).
} 


\subsection{El componente estético de la experiencia}

La relación de Simmel, y específicamente del proyecto sociológico y filosófico que él encarnó, con el componente estético que fue su marca distintiva, ha sido interpretada de múltiples maneras de las que sería excesivo dar cuenta en este capítulo. Sin embargo, resulta importante mencionar algunas, dado que aparecerán a lo largo de nuestra reconstrucción. En principio, sin gran polémica, Simmel es reconocido como raíz de algunas tradiciones que son muy relevantes en las discusiones actuales y que tienen en común una cierta transdisciplinariedad que reconocen como necesaria para el estudio de fenómenos culturales complejos, como los estudios culturales (fundamentalmente lo que se llamó Kulturwissenschaft en Alemania, pero también los Cultural Studies de la tradición norteamericana) y la sociología del arte (o estudios sociales del arte).

Ahora bien, algunos autores han tendido a ver en la atención al arte y, más allá de él, a las configuraciones estéticas por parte de Simmel una caída en una visión "estetizante" del mundo, como si él mismo no hubiese podido evitar quedarse fascinado ante la apariencia de la superficie de su propio objeto de estudio. Sobre el final del capítulo nos referiremos a esta postura para distanciarnos de ella. Por ahora, nos interesa insistir en el modo en que la relación de Simmel con la estética resulta relevante para nuestro estudio: en la interpretación que proponemos, sus consideraciones aparecen como antecedentes atendibles del diagnóstico benjaminiano de una crisis de la experiencia y de una estetización de la política en manos del fascismo que es su punto más álgido y en el que se advierten los mayores peligros.

En este marco, y si bien encontrar en Simmel una denuncia similar implicaría forzar sus palabras, defenderemos la idea de que este autor sentó las bases para que un diagnóstico como el benjaminiano fuera posible, al poner en el foco de atención el modo en que la dimensión estética de nuestra vida cotidiana fue acrecentando, gradualmente, su importancia 
hasta impregnar e informar una gran parte de nuestras actividades y de los aspectos de nuestra vida $^{54}$. En palabras de Simmel, tal aspecto impregna

desde la arquitectura de las viviendas a la impresión de libros, desde las esculturas a los jardines y la decoración de habitaciones, en las cuales se acumulan, al mismo tiempo, el Renacimiento y el orientalismo, el barroco y el estilo imperio, el prerrafaelismo y la regularidad del realismo. (Simmel, 1976, pp. 581-582)

Consecuentemente, intentaremos en primer lugar dar cuenta de este interés en revelar una dimensión estética propia de todas las interacciones sociales, dimensión que no percibimos inmediatamente en nuestra vida cotidiana (Frisby, 1992a, pp. 135-136) con ayuda de tres textos de Simmel, a saber, "Exposición comercial de Berlín" [1896], "Sociología de la comida" [1910] y "Filosofía del paisaje" [1913]. Buscaremos dar cuenta, con estos tres trabajos, del modo en que Simmel es capaz, no sólo de descubrir este componente estético de nuestra experiencia, sino también de percibir el acrecentamiento de su importancia alrededor del despuntar del siglo.

Principalmente, como señala Kösser, Simmel “tematiza una estetización en relación al mundo de las mercancías" (Kösser, 2006, p. 456), como el mobiliario o los productos de la moda, y señala, aporta Featherstone, un "proceso de introducción de la estética en áreas no estéticas" (2007, p. 73). Aun así, el análisis se extiende a mucho más que el simple aspecto llamativo que los bienes adquieren para atraer al público a su consumo. Los productos de consumo fueron también en otras épocas embellecidos: típicamente, los productos de lujo, el mobiliario y el vestido propio de las monarquías, pero también los espectáculos dirigidos a las

\footnotetext{
${ }^{54}$ De la Fuente, siguiendo en esto a Jeremy Tanner, ha llamado la atención acerca del riesgo que implica, para la evaluación valorativa de la filosofía y la sociología de Simmel, centrar su recepción en este aspecto, como en su opinión realiza Featherstone (2008, p. 346). Ahora bien, y dado que el objetivo de nuestra investigación no es, ni implica, una reconstrucción de las ideas de Simmel ni una evaluación de su trayectoria o de su importancia, creemos que el énfasis en este aspecto de su obra está justificado. Si bien compartimos las ideas de De la Fuente, en el caso de una investigación de corte problemático como la nuestra es menester hacer ajustes y recortes en obras de pensadores que, obviamente, exceden el lugar que ocupan aquí.
} 
masas, como los desfiles militares. Aun así, algo de la dimensión estética que Simmel percibe, y a la que nos referiremos a lo largo de este capítulo, no se limita ni se agota en el eje de la belleza, sino que explora más profundamente el modo en que lo estético impone, en el contexto de la configuración de las ciudades, un cierto régimen, en la medida en que organiza la experiencia de una manera específica ${ }^{55}$.

Asimismo, Simmel observa que la prelación del consumo -en el sentido de que el embellecimiento del producto busca fomentarlo y está, así, puesto a su merced- no es tan clara como se esperaría. Los productos de la industria, los logros del capitalismo, la grandeza del dinero, son también objetos de exposición, y así se presentan en un evento de la envergadura de la Exposición Industrial de Berlín de 1896. Este evento, de dimensiones difíciles de imaginar $^{56}$ reunió por 168 días no sólo productos industriales, sino también alimentos, espectáculos y hasta una representación de la vida en las colonias alemanas en África para la cual fueron llevados a Berlín habitantes de dichos territorios, en el marco de la Exposición colonial alemana [Deutsche Kolonialausstellung] que formó parte del evento.

En el texto que le dedica a esta exhibición del poderío de la Alemania que hace su entrada en la edad moderna ${ }^{57}$, titulado simplemente "Berliner Gewerbe-Ausstellung", Simmel pone en juego varios elementos que son útiles para comenzar a delinear el concepto de estetización: por un lado, la observación de que, debido a la competencia, "la producción de

\footnotetext{
${ }^{55}$ Aquí, y si bien no estamos usando un vocabulario propiamente simmeliano, en tanto el objetivo del capítulo es dar cuenta del modo en que Simmel se constituye en un antecedente relevante de aquellos que hicieron un diagnóstico específico de procesos estetizantes, es posible notar como en sus ideas pueden encontrarse antecedentes también para otros desarrollos teóricos actuales. Entre ellos, la relación con las ideas de Rancière es digna de destacar. En su libro "Aisthesis. Escenas del régimen estético del arte", por ejemplo, el filósofo se refiere a las reflexiones de Simmel sobre el estilo y, más generalmente, el influjo de Simmel puede ser visto en el proyecto general de Rancière y en su preocupación por comprender el tejido mismo de la experiencia sensible y sus modificaciones. Para algunos aspectos específicos de esta relación, ver Mallamaci (2018) y Ferrer Rey (2020).

${ }^{56}$ Sobre la exposición, resulta interesante el análisis de Rowe (1995), así como el libro de 1997 Die Berliner Gewerbeausstellung 1896 in Bildern, editado en 1997 por la Bezirksamt Treptow von Berlin.

${ }^{57}$ Como indicamos en el sexto capítulo de esta investigación en torno a la filosofía de Heidegger y a partir del análisis de la técnica que desarrolla Parente (2010a), el proceso de modernización de Alemania, diferente del de otros países europeos, es muy relevante para la tematización de la técnica, la vida en las ciudades y en general la experiencia alrededor del comienzo del siglo XX.
} 
bienes debe dar a las cosas, más allá de su utilidad, un exterior tentador” (2005, pp. 36-37), por el otro, el señalamiento de la importancia del modo en que están dispuestos, con la lógica y el estilo propios de la exposición (2005, p. 35).

Como Simmel deja en claro, se privilegia, más que el valor de uso o la calidad de las cosas, el atractivo que poseen en la vidriera [Schaufenster-Qualität] (2005, p. 36), cuya exaltación es la lógica misma de la exhibición y de su productividad estética [ästhetische Produktivität] (2005, p. 36). El modo en que detecta esa cierta cualidad de los bienes de resultar atractivos en los escaparates es, para Kösser, una de las formas en las que Simmel se refiere, efectivamente, a la estetización sin utilizar este concepto (2006, p. 456).

Dorothy Rowe (1995), en el marco de su interpretación del texto de Simmel, dice sobre la exposición:

Esto fue, en efecto, precisamente aquello de lo cual se trató la exhibición -el espectáculo del trabajo y la industria en el emplazamiento de un parque de atracciones para los ciudadanos $[\text { Bürgers }]^{58}$ de clase media de Berlín; la representación del trabajo industrial se convirtió aquí en una centrada en el placer de la producción y el consumo, en el que el trabajo se convirtió en el tema de un discurso primordialmente estético por sobre uno socioeconómico. (1995, p. 222)

Específicamente, Simmel se centra en dos aspectos de la exposición. En primer lugar, se refiere al carácter de entretenimiento del evento y específicamente a la sensación general de que allí uno debería divertirse [die Vorstellung, dass man sich hier amüsieren soll] (Simmel, 2005, p. 33), acercando el mirar productos con un espectáculo, y dejando de lado, o al menos quitándole preeminencia, a la compra. Queda en evidencia una forma de consumo de los productos industriales, de los productos que dan testimonio del poderío económico del país, que se acerca al modo de consumo del arte: la distancia contemplativa con los objetos de la

\footnotetext{
${ }^{58} \mathrm{Si}$ bien el texto está en inglés, la palabra "ciudadanos" aparece en alemán en el original.
} 
industria, sumada a la estilización de la que son objeto y al cuidado trabajo de curaduría y montaje los convierte, casi, en obras de arte. Lo que resulta fundamental de la observación que Simmel realiza en este sentido es que revela el valor de exposición, de exhibición, de los objetos más allá de su valor de uso y su valor de cambio. El consumo, como es evidente hoy en día, no responde simplemente a la relación entre estos valores, sino que se encuentra fetichizado, en la medida en que los objetos de consumo presentan rasgos auráticos ${ }^{59}$. En palabras de Rowe:

\begin{abstract}
Simmel nota que "el estilo específico de exhibición se ve en su forma más clara en los edificios", y en efecto, el estilo arquitectónico de esta exhibición fue diseñado deliberadamente para evocar una fantasía oriental en la que los productos de la industria de Berlín resultaran estetizados en un entorno que destaca el espectáculo que conformaba lo allí dispuesto en lugar de la función del 'trabajo productivo'.
\end{abstract} (1995, p. 223)

En segundo lugar, Simmel se refiere a la experiencia de confusión y fascinación que la cantidad impresionante de estímulos y novedades producía en los visitantes. El arsenal conceptual que Simmel despliega en este corto texto para referirse a esta sensación es una muestra de esa capacidad de mostrar que caracterizó también a los textos de Benjamin: habla de una "parálisis de la percepción" [Paralyse des Wahrnehmungsvermögens] (2005, p. 33) y de una "verdadera hipnosis" (2005, p. 33), que recuerda al concepto de Anästhetisierung que analizamos en el primer capítulo de esta investigación. A su vez, se refiere a que

toda sensibilidad delicada y sensible se sentirá violentada y trastornada por el efecto masivo [Massenwirkung] de lo que se ofrece aquí, pero, por otro lado, no se puede negar que la plenitud y la variedad de las impresiones pasajeras es apropiada para

\footnotetext{
59 El concepto de "aura" resulta, como expondremos en los capítulos referidos a Benjamin, central en su producción, y algunos de sus rasgos se pueden encontrar prefigurados en las reflexiones simmelianas. Si bien Benjamin presenta más de una caracterización del aura, la más célebre reza que se trata del "aparecimiento único de una lejanía, por cercana que pueda estar [einmalige Erscheinung einer Ferne, so nah sie sein mag]" (Benjamin, 2015b, p. 31; GS I 440).
} 
la necesidad de excitación de los nervios estresados y cansados [überreizter und ermatteter Nerven]. $(2005, \text { p. } 34)^{60}$

Lo estetizado, en la Exposición de Berlín, no son solo los productos industriales, expuestos de modo tal que adquieran un valor nuevo o el valor de exposición que supo tener otro tipo de bienes, sino la experiencia en sí, organizada de manera tal que el sujeto no logre involucrarse de manera práctica ni crítica con lo que ve: su vivencia se ve moldeada por la fascinación confundida, alienada, hipnótica, que lo aleja de aquello que está allí para él pero con lo que no entra en contacto. En su enormidad, la exposición se impone dominando al paseante que no es capaz de abarcarla ni de comprenderla. Como mecanismo de defensa, este se adormece y simplemente recorre el paisaje industrial que el capital le ofrece.

No casualmente habla Simmel de lo allí reunido, heterogéneo, en términos de imagen, cuando dice que lo característico de este tipo de eventos es la impresión de que "el trabajo de todo el mundo se ha reunido aquí, como en una imagen, en este espacio estrecho y limitado" (2005, p. 35. Las cursivas son nuestras). El sujeto, sobresaturado por los estímulos, los recibe sólo como imágenes y se deja entretener. Los productos del trabajo alienado, del trabajo mal pago, de la división en clases, e incluso los productos del avance de Alemania sobre el mundo encarnados en los 103 habitantes de las colonias africanas puestos a disposición del hombre blanco para ser observados, todo esto, que podría implicar una experiencia política, un despertar de la conciencia social o de la solidaridad con los oprimidos, no genera ninguna de estas reacciones: la experiencia social o política posible es cancelada a base de

\footnotetext{
${ }^{60} \mathrm{El}$ análisis del exceso de estímulos a los que la técnica somete al hombre es analizado también, como recuerda Melamed (2010) por Proust. En la novela se anticipan preguntas que, como sostiene la autora, se relacionan muy directamente con problemas actuales, en tanto hoy cabría preguntarse "¿Qué capacidad reflexiva no se anula cuando puede presenciar en primera fila, y de la mano del control remoto, la guerra, el dolor, la destrucción, la muerte? ¿qué sensibilidad no se ve superada por el efecto devastador de lo hiperreal dentro de su propio living?" (p. 150). Sobre la relación entre Benjamin y Proust puede consultarse también Melamed (2013).
} 
sobreestimulación y apariencia agradable ${ }^{61}$. El pequeño mundo que es la exposición se presenta como imagen muda, como paisaje o como escenografía, como aquello que no tiene agencia.

Simmel no limita su análisis estético a hechos que posean carácter de cosa, sino que lo extiende más allá del mundo de la mercancía, haciendo evidente que de lo que se trata es de una modificación profunda en el modo de relación con el mundo.

En "Sociología de la comida" ["Soziologie der Mahlzeit"], de 1910, Simmel se refiere al procedimiento mediante el cual la comida dejó de representar simplemente la satisfacción de una necesidad orgánica y se convirtió en una práctica social reglada y estetizada. En el nivel más básico, entonces, el ensayo permite ejemplificar este hallazgo propio de Simmel, a saber, que nuestra vida se ve atravesada por una dimensión estética que no es exclusiva del arte, y que entonces el comer "exige además del fin de saciar el apetito también una satisfacción estética" (2001b, p. 403).

No obstante, dos elementos convierten a este texto en una pieza cuyo alcance sería injusto limitar a simple ejemplo de una regla más o menos general. En primer lugar, la estetización de la comida, lejos de ser un mero ejemplo, funciona como indicador de una tendencia: "Simmel ve la comida como el microcosmos de un orden social estetizante" (De la Fuente, citado por Sabido Ramos, 2016, p. 157), a pesar de que, a diferencia de lo que ocurre con respecto al paisaje -como veremos a continuación-, en el caso de la comida el rango posible de alejamiento es menor, ya que la función de la comida, esto es, el entrelazamiento práctico con ella, se mantiene. En este sentido, dice que "la estética de la comida no puede olvidar nunca qué es lo que realmente tiene que estilizar: una satisfacción de necesidades situada en las profundidades de la vida orgánica" (Simmel, 2001b, p. 406). Este punto es importante en la medida en que, si bien mediante este proceso de estilización la comida se nos

\footnotetext{
${ }^{61}$ Como veremos algo más adelante, Simmel da cuenta, en otro texto, de la imposibilidad de volver mera imagen la presencia de otros sujetos, lo que deja en evidencia el sesgo racista que se pone en juego a la hora de lograr este alejamiento de los otros cuando se trata de sujetos esclavizados y presentados en su carácter de posesiones exóticas.
} 
aleja (hay tiempos para comer y hay modos y criterios que exceden la satisfacción simple de una necesidad) mantiene siempre un anclaje en su valor de uso ${ }^{62}$.

En segundo lugar, Simmel compara en su texto el componente estético de la comida con el de una obra de arte y, al hacerlo, da claves para comprender mejor su concepción del arte, que confirman la importancia de la distancia: "Mientras que la belleza de la obra de arte tiene su esencia en la intangibilidad que nos mantiene a distancia, el refinamiento de la mesa consiste en que su belleza nos invite a sentarnos en ella" $(2001 \mathrm{~b}, 407)^{63}$.

La belleza, y en este sentido la estilización de un producto, puede operar entonces en dos sentidos contrarios: acercando o alejando. En el caso de la comida, como en el de la mercancía, la belleza cumple el fin de atraer. En el arte, la belleza es lo que vuelve a la obra intocable, esto es, es un elemento que indica que aquella pieza está, usando la terminología de Agamben, retirada del uso. Esta diferencia, no obstante, se manifiesta de un modo no tan lineal en el proceso de refinamiento de los platos: si bien la estilización atrae (haciendo a la comida más deseable), todo el ensayo es una explicación acerca de cómo el acto de comer se vio cada vez más mediado y la relación con la comida se tornó más distante. Del mismo modo, en el texto sobre la Exposición de Berlín, la manera de hacer atractivos los productos es alejarlos y retirarlos de la esfera de lo práctico o de lo útil.

\footnotetext{
${ }^{62}$ Los textos que Benjamin escribe sobre experiencias con comida resultan en este punto muy relevantes, aunque centrarnos en dicho tema excede los límites de esta investigación. En "Higos frescos", por ejemplo, Benjamin narra el modo en que compra y come desaforadamente esta fruta, y escribe: "Quien siempre comió con moderación, nunca experimentó lo que es una comida, nunca sufrió una comida. Así, a lo sumo se conoce el placer de comer pero no la voracidad, el desvío desde la llana avenida del apetito hacia la selva de la gula" $(2011 \mathrm{c}, \mathrm{p}$. 95). El relato está unido al envío de una carta que el autor está aplazando, y recuerda más a la experiencia proustiana que al alejamiento de la comida en una relación estetizante con ella a la que refiere Simmel. Aun así, esa relación está problematizada, en este y otros textos, como lo que quiere evitarse en busca de una experiencia más enriquecedora.

${ }^{63} \mathrm{La}$ forma en que Simmel entiende nuestra relación con la obra de arte como estando ligada a la distancia recuerda a la idea kantiana de desinterés estético. En efecto, y si bien no nos centraremos en ello, la de Kant es una de las influencias más importantes en la formación del pensamiento de Simmel. Según Werner Jung, "El desarrollo intelectual de Georg Simmel comenzó con una discusión sobre Kant, así como unos pocos años después, siguió con consideraciones metodológicas fundamentales respectivas a la ética, centralmente, luego también se abocó a cuestiones de filosofía de la historia y problemas de una teoría general de la comprensión” (Jung, 2016, p. 109).
} 
A su vez, este texto resulta relevante, como adelantamos, porque Simmel utiliza en él el concepto de estetización. Sobre el final de su análisis, y en alguna medida anticipando objeciones respecto del tema elegido, considerado algo primitivo y de rango poco filosófico, el autor sostiene que, si la comida "no fuera algo tan bajo, no habría encontrado, pues, este puente, atravesando el cual asciende hacia la significatividad de la comida sacrificial, hacia la estilización y estetización de sus últimas formas [Stilisierung und Ästhetisierung seiner schließlichen Formen]" (2001b, 409-410. El enfatizado es nuestro). El trasfondo de la relación estetizante con el mundo es otro tipo de relación de índole práctica que está, como queda claro en el ensayo sobre el paisaje que analizaremos a continuación, en crisis. Como veremos en el sexto capítulo, Heidegger será autor de un diagnóstico similar.

El texto más paradigmático del modo en que Simmel comienza a percibir que un cierto componente de lo estético empieza a configurar nuestra experiencia del mundo es justamente el ensayo breve de 1913 titulado "Filosofía del paisaje". Allí, Simmel realiza una cierta ontología del paisaje: se pregunta por su ser propio, por aquello que lo determina como tal, y comienza dando cuenta del carácter moderno del paisaje como configuración. En sus palabras:

Precisamente, las religiones de los tiempos más primitivos me parece que manifiestan un sentimiento especialmente profundo hacia la 'naturaleza'. Sólo la sensación de la imagen [Gebilde] específica 'paisaje' ha nacido posteriormente, y en verdad porque su creación exige un despegarse de aquel sentir unitario de la naturaleza en su totalidad. (2001c, pp. 267-268. El enfatizado es nuestro)

\section{Asimismo, agrega que}

no hay que sorprenderse de que ni la Antigüedad ni la Edad Media tuvieran sentimiento alguno del paisaje ${ }^{64}$; precisamente el objeto mismo aún no existía en

\footnotetext{
${ }^{64}$ Este pasaje de Simmel y, en general, el texto, recuerdan en su estructura argumentativa a "La época de la imagen del mundo". Allí y como detallaremos en el capítulo 6, Heidegger da cuenta de que no hay una imagen medieval
} 
aquella firmeza anímica y transformabilidad autónoma, cuyo logro final confirmó entonces y, por así decirlo, capitalizó el surgimiento de la pintura paisajista. (2001c, p. 268. Enfatizado en el original)

Estos pasajes merecen una lectura atenta. Lejos de estar corroborando, meramente, el proceso de separación del hombre de la naturaleza, el desplazamiento de la vida humana hacia un centro que no refiere ya al eje de las necesidades que podríamos denominar naturales ${ }^{65}$, Simmel está haciendo mucho más: está ligando ese proceso a una operación estética. En este sentido, no resulta casual que, como en el caso de la Exposición de Berlín, utilice el concepto de imagen. La naturaleza aparece, a lo sumo, como una cierta condición de posibilidad para que se configure aquello que entendemos como paisaje, pero no es suficiente, en tanto "paisaje" es una categoría estética, un tipo de imagen que necesita de una cierta autonomía y de un despegarse por parte del sujeto de aquello que podría ser percibido como el entorno. El paisaje, para existir, debe ser organizado y percibido como tal. La naturaleza, en esa operación, se nos aleja.

En este sentido, en su Filosofía del dinero se referirá Simmel a

aquello que es la naturaleza para nosotros, esto es, una imagen espiritual remota que, incluso en los momentos de proximidad corporal, se encuentra frente a nosotros como algo íntimamente inalcanzable, como una promesa jamás realizada, como algo que respondiera a nuestra entrega más apasionada con un rechazo y una extrañeza ligeras. (1976, p. 604)

ni una antigua del mundo, sino solo una imagen moderna del mundo porque la modernidad es la época en la que el mundo se configura como imagen.

${ }^{65}$ Aun así, la postulación de este proceso de separación no es ajena a Simmel. Como menciona Simonis, Simmel tiene esto en común con Max Weber, en tanto comparten la experiencia de la diferenciación y el distanciamiento propios de la época moderna, así como la experiencia de la racionalización y del avance de la técnica (1999, p. 613). 
Cuando se pregunta qué es lo que configura, finalmente, un paisaje, Simmel afirma que para comprenderlo debemos referirnos al artista, en tanto la operación que este realiza y la que realiza cualquier persona cuando observa un paisaje son una y la misma. En sus palabras:

Precisamente esto, lo que el artista hace: delimitar un trozo a partir de la caótica corriente e infinitud del mundo inmediatamente dado [chaotischen Strömung und Endlosigkeit der unmittelbar gegebenen Welt], aprehenderlo y conformarlo como una unidad [eine Einheit] que encuentra su sentido en sí misma y que ha cortado los hilos que lo unen con el mundo [die weltverbindenden Fäden abgeschnitten hat] y que ha anudado de nuevo en el propio punto central, precisamente esto hacemos nosotros en menos medida, menos fundamental, de forma fragmentaria $\mathrm{y}$ de contornos inseguros [in fragmentarischer, grenzunsichrerer Art], tan pronto como en lugar de una pradera y una casa y un arroyo y el paso de las nubes, contemplamos un 'paisaje'. (2001c, p. 270. Las cursivas son nuestras)

\section{Para Simmel,}

el arte proviene de la vida, pero sólo porque y en la medida en que la vida, tal y como es vivida cotidianamente en todas partes, contiene aquella fuerza configuradora [Formungskräfte] cuya consecuencia pura, que se ha tornado autónoma, que determina su objeto por sí, se denomina entonces arte. (2001c, p. 273. Las cursivas son nuestras)

La operación del arte, entonces, no tiene que ver, o no centralmente, o no solamente, con la belleza (Müller, 2018, p. 58), sino con una cierta forma de organización. Así lo entiende, entre otros, Michel Maffesoli, cuyas ideas recupera Eduardo De la Fuente para pensar el fenómeno de la estetización en el contexto de las sociedades contemporáneas, en tanto sostiene que "el modo estético de existencia social característico de las sociedades posmodernas (...) tiene muy poco que ver con las 'bellas artes' y más que ver con la 'estética como una manera de sentir y experimentar en común"” (en De La Fuente, 2008, p. 346). Este punto resultará 
central para nuestro análisis, en la medida en que permite situar las reflexiones de Simmel como las predecesoras de la forma de entender la estetización que defendimos en el capítulo 1, esto es, como una operación organizadora de la experiencia.

Otro aspecto de este corto escrito que resulta muy relevante para nuestro estudio es el modo en que Simmel analiza las razones para que este proceso -que proponemos entender como una cierta operación de estetización de la naturaleza- se de con más facilidad en torno al paisaje que a otros estímulos a los que estamos expuestos.

La comparación que articula la argumentación es entre los elementos con los que conformamos el paisaje y la visión de otra persona. Simmel encuentra que, cuando estamos frente a otra persona, no somos capaces de realizar la misma operación que ponemos en marcha frente a, por ejemplo, árboles, una casa y una pradera. Y es que el paisaje, explica, se coloca a "una distancia [Distanz] frente a la objetividad que favorece el comportamiento artístico [dem künstlerischen Verhalten] y que no es alcanzable ni fácil ni inmediatamente respecto de la visión de otro hombre" (2001c, p. 274). A continuación, buscando las razones por las que nos es difícil ver, en el otro, una imagen, un paisaje humano, agrega: "aquí nos estorban en esto las desviaciones subjetivas en virtud de la simpatía y la antipatía, los entrelazamientos prácticos [die praktischen Verflochtenheiten]" (2001c, p. 274).

Recapitulando, aquello que nos permite ver el paisaje es nuestro alejamiento de la naturaleza, el hecho de que nuestra vida se haya apartado de ella, de que tengamos con ella cada vez menos "entrelazamientos prácticos". Por su parte, los otros hombres ${ }^{66}$ son, para Simmel, todavía algo que no podemos transformar, tan simplemente, en objeto y en imagen. Este impedimento se pone en cuestión a medida que la estetización se empieza a percibir como un problema social y político que alcanza a los otros e incluso a la relación que el sujeto entabla

\footnotetext{
${ }^{66}$ Se trata, claro, de los otros cuando son considerados pares, como muestra el ejemplo de la Exposición Colonial al que nos referimos más arriba. Allí, y si bien los sujetos esclavizados eran exhibidos y exotizados en una operación que sin dudas es de estetización, esta operación es posible allí en tanto se trata de sujetos a los que se les niega el reconocimiento como tales.
} 
consigo mismo. Aun así, nos interesa hacer especial hincapié en cómo Simmel es capaz, en este ensayo, de iluminar el hecho fundamental de que la operación artística implica una cierta manera de mirar que toma distancia y que pone entre paréntesis las implicaciones prácticas con aquello que convierte en objeto.

El texto sobre el paisaje revela una realidad de los procesos estetizantes, y es que no se sitúan solamente en el mundo, esto es, en algo dispuesto a propósito para nuestro deleite visual o en aquello que busca convertirse en el objeto de nuestro goce estético o de nuestro entretenimiento - como en el caso de la Exposición de Berlín y en general de las mercancías que se presentan enfatizando su valor estético, o incluso en el caso de la puesta en escena propia del nacionalsocialismo--. No se trata siempre del embellecimiento o la estilización del mundo: también algo que ya estaba ahí (la pradera, la casa) puede ser convertido por nosotros, en una operación que habita del todo en nuestra propia subjetividad, en objeto estético. Lejos de montar el paisaje, lo encontramos ahí, donde siempre estuvo, pero lo configuramos en la percepción como paisaje. La estetización habita ya en nuestra mirada: son nuestros ojos los que buscan la imagen donde antes estaba el mundo.

Como muestra Simmel, este proceso mediante el cual juzgamos estéticamente aquello que percibimos, reduciéndolo a la imagen que proyecta, tiene lugar también con respecto a fenómenos sociales y cotidianos de diferentes índoles. El ensayo "Estética sociológica" resulta en este sentido de suma importancia. La tesis central, que no desarrollaremos aquí, es que: "La cuestión social no es sólo una cuestión ética, sino también estética” (Simmel, 1992, p. 220), y en este sentido, "no nos guía solo la racionalidad" (Müller, 2018), y aun si lo hiciera, "ella también tiene un componente estético" (Müller, 2018).

Una forma de organización política, dirá Simmel en este ensayo, puede ser apreciada estéticamente, en relación al tipo de configuración que propone. Entre la estética y la política, el autor encuentra sugerentes concordancias de formas o estructuras. La influencia de las 
fuerzas estéticas sobre los hechos sociales - dirá- se torna visible de la forma más resuelta en el moderno conflicto entre las tendencias socialistas e individualistas (Castillo, 1998, p. 314).

En efecto, en este ensayo de 1896 Simmel se refiere a lo que él llama "cosmovisión estética" [ästhetische Weltanschauung] y sostiene:

La esencia de la contemplación [Betrachtung] y la representación [Darstellung] estéticas reside, para nosotros, en el hecho de que descubre, en el individuo, el tipo; en lo contingente, la ley, y en lo aparente y fugaz el ser y el significado de las cosas. (1992, p. 64)

Simmel observa entonces, por un lado, un componente estético de nuestra experiencia que es parte de nuestra vida y que tiene un impacto relevante en nuestras decisiones. Sin embargo, lejos de considerar este aspecto de nuestra percepción como algo dado, logra dar cuenta de su aspecto histórico y del modo en que esta dimensión estética en nuestra apreciación del mundo cobra, ya desde finales del siglo XIX y más aún a principios del siglo XX, una importancia cada vez mayor.

En este contexto, el arte no sólo cambia la forma en que vemos el mundo (como en el caso de nuestra percepción de un paisaje mediada por el conocimiento de las pinturas de paisajes) sino que traspasa, a su vez, las fronteras de la obra para dar lugar a objetos de uso cotidiano estetizados, de modo tal que la diferencia entre la obra de arte y ciertos objetos de uso se hace un poco más borrosa. En este sentido, “Simmel observa la estetización del mundo de la vida tal y como se da en el Jugendstil, en tanto los productos de uso cotidiano poseen diseños inconfundibles y las artes aplicadas reclaman ser consideradas 'arte'” (Müller, 2018, p. 56).

Asimismo, y como mencionamos, los cambios en los modos de vida propios del acrecentamiento de los estímulos en la vida urbana resultan centrales para comprender los procesos estetizantes: "el fundamento psicológico sobre el que se alza el tipo de 
individualidades urbanitas”, dirá Simmel en "Las grandes urbes y la vida del espíritu”, "es el acrecentamiento de la vida nerviosa, que tiene su origen en el rápido e ininterrumpido intercambio de impresiones internas y externas" (2001d, p. 376). En efecto y como menciona Ingo Meyer (2018) Simmel anticipa el concepto de shock de Benjamin (p. 132), y trabaja, como él, con una batería terminológica relativa a los nervios. Así como Benjamin basa su comprensión de la experiencia en un análisis neurológico con centro en el shock-como detallaremos en el capítulo 5 y como observó Susan Buck-Morss (2015, p. 174)- en Simmel el análisis del impacto fisiológico de los estímulos es asimismo central. Las modificaciones en la capacidad de percepción, el modo en que el organismo se defiende de la sobreestimulación y la referencia a la neurastenia son solo algunos ejemplos de la manera en que este impacto modifica la vida en las ciudades.

Por otro lado, Simmel es capaz, como desarrollaremos en el próximo apartado, de iluminar el proceso de estetización como una tendencia que comienza a formar parte de nuestra configuración como sujetos. Aun así, no puede obviarse el hecho de que su postura frente a la estetización ha sido ambivalente, en tanto confió, en alguna medida y como sostiene De la Fuente, en la posibilidad de que la estilización y la estetización de las formas sociales actuaran haciendo efectivos los pactos sociales. En efecto, "en la sociología de Simmel, el paralelismo entre las formas sociales y las formas estéticas es por momentos tan fuerte que da la impresión de que los factores estéticos, en efecto, fortalecen los lazos sociales" (De la Fuente, 2008, p. 344).

Como desarrollaremos en el próximo capítulo, Benjamin, algunos años más tarde, ya sin ambigüedades, observa el proceso estetizante como un peligro. Aun así, sus observaciones no están tan lejos de las de Simmel. La función social de las formas estéticas se mantiene; sin embargo, en un momento histórico en el que la configuración social que se propone es una amenaza para la humanidad, el juicio necesario no es estético sino político. Antes de abocarnos 
a ello, no obstante, es importante delinear más precisamente la concepción de la estetización que puede desprenderse de los escritos de Simmel, en la que la prelación de la distancia resulta central.

\subsection{Estetización y distancia: experiencia, arte, dinero}

Para continuar precisando los contornos de aquello que nombramos cuando nos referimos a procesos de estetización, y habiendo realizado un cierto recorrido por aquellos ámbitos que Simmel encuentra afectados por la prelación de lo estético, cabe ahora preguntarnos qué es lo que el arte aporta, traslada o contagia a estos ámbitos, o, con otras palabras, qué es en este contexto lo estético. En el caso del paisaje, en la exposición industrial y en la comida, como hemos intentado mostrar, se descubre que la distancia, como parte fundamental de una forma especial de mirar, configura una experiencia específica que, despegándose de la acción que las cosas tienen o podrían tener sobre nosotros, las transfigura en imagen. En los tres casos, también, aparece el arte indicando que esa distancia está marcada por lo estético -y no por lo dinerario o lo religioso, como ejemplos de otras fuerzas que operan distanciamientos-: en la exposición industrial, los objetos se exhiben, como las obras, y se relacionan con el sujeto más como paseante en una galería que como comprador potencial; en la comida, la satisfacción que se busca es explícitamente estética, y el atractivo del plato es comparado por el mismo Simmel con el de una obra de arte; en el paisaje, una forma artística concreta, un cierta imagen producida por el arte, ayuda a configurar una experiencia de la naturaleza típicamente moderna, en tanto "cada arte va determinando lentamente la forma en que vemos la naturaleza" (Simmel, 1976, p. 559).

Nos interesa especialmente destacar el modo en que Simmel interpreta al arte como operando no sólo una representación del mundo sino también una modificación del sujeto, o 
cumpliendo una función en alguna medida conformadora de lo que percibimos. En sus propias palabras, en las que los lectores de Benjamin encontrarán sus ecos: "Todo arte transforma la perspectiva en la que, originaria y naturalmente, nos situamos frente a la realidad" (1976, p. 597), en la medida en que "ordena y transforma la inmediatez de la impresión merced a determinados presupuestos y exigencias" (1976, p. 597. El enfatizado es nuestro). El arte aquel al que Benjamin se referirá como arte aurático- organiza la experiencia, mediatizándola, de un modo específico que pone a lo que es visto más allá del uso, quebrando la relación originaria de implicación con el objeto y distanciándolo. Esta organización propia del arte, el modo en que configura su objeto, supone operaciones en el espectro de lo espacial de las que Simmel da cuenta con el bagaje conceptual que pone en marcha, con palabras como "perspectiva", "situarse" e "inmediatez".

En esa operación espacial, el mundo no sólo se aleja, sino que, al hacerlo, cambia de naturaleza: mientras que los elementos naturales, en la cercanía, pueden ser percibidos en su carácter de refugio, o como amenaza, fuente de calor, de frío, de humedad, de comida, abrigo o consuelo, en la distancia sólo pueden configurar un paisaje, esto es, una imagen. En su Filosofía del dinero dirá Simmel en este sentido:

lo alejado origina muchas representaciones, vivaces o de carácter oscilante $\mathrm{y}$, de este modo, satisface a nuestra necesidad de estímulos; sin embargo, debido a su falta de relación con nuestros intereses más inmediatos y personales, estas representaciones extrañas y alejadas tienen poca resonancia y, por este motivo, únicamente suponen una excitación agradable para una recepción nerviosa debilitada. (1976, p. 598)

Jakob Schultz y Steven Sello (2018), responsables de la entrada sobre la distancia [Distanz] en el Handbuch de Simmel se refieren a ella como una cierta figura del pensamiento [Denkfigur] del sociólogo y filósofo alemán que, sin ser un concepto, atraviesa y estructura sus 
ideas con un carácter propio. La referencia a la distancia aparece en su obra estructurando la relación entre sujeto y objeto, así como también el análisis del dinero, del arte, del conocimiento y fundamentalmente de la vida en las ciudades, donde una cierta separación aparece como necesaria para que el sujeto se resguarde de los estímulos que lo acechan.

Refiriéndose a la vida en las ciudades, por ejemplo, dirá Simmel en “Die Großstädte und das Geistesleben":

La concentración tan alta de hombres y cosas estimula el sistema nervioso del individuo hasta sus máximos grados de excitación. Por medio de la mera intensificación cualitativa de los mismos factores condicionantes esta excitación se transforma en su opuesto y desemboca en el hastío tan peculiar en la actitud blasée (Simmel, 1995, p. 122) ${ }^{67}$,

y en formas patológicas de miedo al contacto con el mundo, como "la hiperestesia ${ }^{68}$ para la cual todo contacto, inmediato y enérgico, constituye un dolor" (Simmel, 1976, p. 598) y las diferentes formas de aislamiento [Vereinzelung] a las que puede arrojar (Schultz y Sello, 2018, p. 170).

La transformación de la formas de vida en el despuntar del siglo es un tema central en la obra de Simmel, así como en la de Benjamin, donde los peligros propios de una crisis de sentido, o de lo que se ha dado en llamar una ruptura de la tradición, se ponen en relación con las violencias propias del período de entreguerras y, ya en la década del 30, con el análisis de las formas de ejercer poder propias del fascismo, para cuya comprensión se hace urgente un análisis de las nuevas subjetividades y del modo en que se relacionan con su entorno.

\footnotetext{
${ }^{67}$ Una cita similar a ésta, en tanto refiere también a la necesidad de resguardo y protección que experimenta el individuo ante los estímulos de la gran ciudad, pero perteneciente a la Filosofía del dinero, es recogida por Benjamin en la Obra de los pasajes (2013, p. 720).

${ }^{68}$ Como afirma Frisby (1992b, p. 80), la neurastenia fue clasificada como condición en la década de 1850.
} 
El hecho de que "lo estético" juegue un rol en esta transformación del mundo, mediante la cual el propio entorno deja de ser un objeto inmediato con el que nos implicamos para transformarse en algo lejano que observamos, podríamos decir, implica una primera forma de estetización. El arte no sólo es estético, sino que expresa una experiencia específica, un modo de organizar la relación con el entorno, ofreciéndonos una forma de mirar que, de las obras, se traslada a otros objetos ${ }^{69}$. A este respecto, en un pasaje que, nuevamente, resuena en algunas frases de Benjamin, dice Simmel:

Todo arte implica un alejamiento de la inmediatez de las cosas, hace que se reduzca el carácter concreto de los atractivos e interpone una especie de velo entre éste y nosotros, de modo similar a aquel aire azulado y fino que rodea a las montañas lejanas. $(1976, \text { p. } 597)^{70}$

La mirada artística, entonces, como en el caso del paisaje, desenfoca el carácter de útil o amenaza de lo que tenemos enfrente y nos lo ofrece velado, protegido por aquello que impide que nos afecte. De la misma manera, propondremos pensar el proceso de estetización, en Benjamin, como un proceso en el que aquello que nos afecta o debería afectarnos en su carácter de fenómeno concreto aparece, distanciado, como mera imagen.

Es por eso que comprender el modo en que el arte transforma nuestra forma de situarnos frente a la realidad resulta central para comprender la potencia y el peligro que encierran los procesos estetizantes. Y una parte esencial de estos procesos es la operación a través de la cual el mundo se nos coloca a una determinada distancia.

\footnotetext{
${ }^{69}$ Como veremos en el capítulo 7 en torno a la obra del artista conceptual Joseph Koruth, el arte y los artistas se alejarán también, en el siglo XX, de esta forma de comprender su actividad.

${ }^{70}$ En su célebre ensayo sobre la obra de arte, Benjamin utilizará el ejemplo de la montaña para hablar del aura. Esta coincidencia fue advertida ya por Krymanski (1990): "Además, el paisaje simmeliano puede haber jugado un rol en la construcción del concepto benjaminiano de aura" (citado por Amat, 2018, p. 352).
} 
Otro ámbito de su producción en el que Simmel se refiere a la distancia son sus reflexiones sobre la economía dineraria. En efecto, la distancia se revela como el puente que une la lógica propia del intercambio económico con la estética:

\begin{abstract}
El conjunto de nuestra vida está caracterizado por el alejamiento de la naturaleza, que impone la economía monetaria y la vida urbana, de ella dependiente. En todo caso, sólo a su través resulta posible la apreciación estética y romántica de la naturaleza. El que no conoce otra cosa que su contacto inmediato, podrá disfrutar de sus encantos de modo subjetivo, pero carece de aquella distancia que es la que posibilita una consideración estética de la misma y a través de la cual surge esa tristeza tranquila, ese sentimiento de extrañeza nostálgica y de paraíso perdido, que caracterizan al sentimiento romántico de la naturaleza. (1976, p. 604)
\end{abstract}

Esta "distancia respecto al objeto" (1976, p. 604) y la "ruptura de la unidad natural con él” (1976, p. 604), que forman parte, como Simmel explica en su gran obra, del modo en que el dinero, en la forma de valor de cambio, obtiene prelación con respecto al valor de uso, son también los elementos que posibilitan la mirada estética, ya que, como explica Frisby, "los juicios estéticos requieren la tensión entre cercanía y distancia, y sus expresiones más modernas están basadas, básicamente, en la distancia” (Frisby, 1992a, p. 138) ${ }^{71}$.

En efecto, la distancia juega un rol crucial en la Sociología del dinero desde el primer capítulo. Allí, Simmel se refiere a la prefiguración de la relación estética en los casos en los que la sola visión de un objeto con el que supimos tener una relación de implicación práctica que nos resultaba beneficiosa nos genera una sensación placentera. En sus palabras:

En lugar de la relación concreta que antes nos unía con él, aparece la mera contemplación como origen de la sensación agradable. (...) En resumen, el objeto nos resultaba valioso la primera vez para nuestros fines prácticos (...), mientras que,

\footnotetext{
${ }^{71}$ Como veremos en el capítulo 6, en Heidegger esta suspensión de la relación de implicación práctica con el mundo es la que ocurre en el trato técnico científico con el mundo.
} 
ahora, es su mera presencia la que nos procura alegría, sin que nosotros, reservados y distantes, lleguemos a tocarla. Aquí aparecen ya prefigurados los rasgos decisivos de lo estético. (Simmel, 1976, p. 37)

Central resulta también el último capítulo, "El estilo de vida", en el cual Simmel logra dar cuenta de las formas de vida que genera y favorece la economía monetaria, con centro en el intercambio y el dinero. Allí, se centra en cómo el dinero, como mero medio, privilegia lo intelectual sobre lo sentimental y lo mediato sobre lo inmediato, imponiendo distancia entre el hombre y las cosas. El incremento de lo medible, pesable y calculable (1976, p. 557) determina para Simmel tanto el crecimiento de ciertos rasgos psicológicos en detrimento de otros como el surgimiento de una cierta cultura propia de las sociedades estructuradas en torno al dinero. En este marco, despliega su teoría de la diferencia entre la cultura objetiva y la cultura subjetiva, que no desarrollaremos aquí pero cuyo centro resumen estos fragmentos de su texto:

Si se compara la época contemporánea con la de hace cien años, se puede decir con ciertas excepciones- que las cosas que llenan y rodean objetivamente nuestra vida: aparatos, medios de circulación, productos de la ciencia, de la técnica y del arte, están increíblemente cultivados, pero la cultura de los individuos (...) no está igualmente avanzada e, incluso en muchos casos, hasta se encuentra en retroceso. (Simmel, 1976, p. 563)

El mundo de la cultura, entonces, se presenta para el individuo como algo lejano, inabarcable. Los avances científicos y técnicos son, como los estímulos de la ciudad, demasiado para el sujeto. La distancia se hace presente también aquí, en el mundo estructurado por la economía dineraria y las lógicas que le son propias, en la forma de una falta de capacidad de acercarse a aquello que teóricamente representa los logros de la humanidad. Como consecuencia, los avances técnicos no se corresponden -siempre desde la posición de Simmelcon avances observables en la cultura de las personas, como queda claro en este fragmento: 
Por supuesto, hoy tenemos acetileno y luz eléctrica, en lugar de las lámparas de aceite; no obstante, el entusiasmo acerca de los adelantos de la iluminación hace olvidar, a veces, que lo importante no es ésta, sino aquello que hace más visible; el delirio en que el triunfo de la telegrafía y la telefonía ha sumergido a los hombres hace que éstos olviden a menudo que lo importante es lo que se ha de comunicar. (1976, p. 609)

En su interpretación, Frisby reconoce la importancia de la distancia, que interpreta como una clave en torno al motivo de la estetización, que, como mencionamos, atraviesa la obra de Simmel sin ser puntualmente tematizado:

En su ensayo sobre la "Estética sociológica" (1896) y en su Filosofía del dinero (1900) (...) Simmel relaciona el esteticismo contemporáneo con la tendencia a distanciarse uno mismo de la realidad. Simmel sugiere que el interés distintivo en ver las cosas desde la distancia parece ser un signo distintivo de los tiempos modernos. Simmel se inclina a relacionar esta distancia con la economía monetaria moderna y la vida urbana que, por un lado, objetiva todas las relaciones sociales, mientras que, al mismo tiempo, crea la necesidad de preservar una distancia estética. (Frisby, 1992b, p. 87)

Teniendo en cuenta las utilizaciones posteriores del término, y típicamente la benjaminiana, la importancia de las ideas de Simmel para teorizar la estetización se descubre en esta intersección entre la economía dineraria y la estructura de la contemplación. Los elementos que forman parte del diagnóstico benjaminiano de una crisis de la experiencia y de la estetización de la política que resulta su punto más peligroso están prefigurados en las ideas de Simmel que hemos presentado aquí. Específicamente, la referencia a una experiencia empobrecida por la distancia a la que el sujeto se coloca del mundo, cuya agencia niega, tiene mucho que ver con el diagnóstico benjaminiano. Esta cerrazón, este aislamiento y el intento por mantener al mundo bajo control, aunque para hacerlo haya que reducirlo a una mera imagen 
de lo que supo ser, involucra una distancia que se caracteriza por una marcada orientación estética, en tanto el entorno, para dejar de ser amenazante, se configura como mero paisaje, en consonancia con "el interés estético de los últimos tiempos [que] se orienta hacia el aumento de la distancia frente a las cosas, ocasionada por la elaboración artística de éstas" (Simmel, 1976, p. 598).

Simmel mismo percibe este retirarse del mundo como una operación que implica la búsqueda de lugares seguros. Al comparar esta "estetización" con la actitud del avaro, que encuentra un goce en simplemente atesorar aquello que podría usar, comenta:

También aquí, sin embargo, tiene que hallarse presente el encanto emparentado con el de carácter estético: la dominación de las formas y las ideas puras de las cosas o los actos, frente a la cual todo avance hacia la realidad, con sus obstáculos, contratiempos e insuficiencias, únicamente puede suponer un descenso y una limitación del sentimiento de dominar absolutamente a los objetos por medio del poder. (Simmel, 1976, p. 397. El enfatizado es nuestro)

Es importante destacar que, en diagnósticos posteriores -en Vattimo, Debord, Lipovetsky y Serroy, entre otros-, esta relación entre distancia y dominio (o ilusión de dominio) se mantiene: en la relación estetizante con el mundo, la facticidad es transfigurada en imagen, en una medida tal que su amenaza se percibe como menor y es subestimada: las masas, dirá Benjamin, fascinadas por la imagen que el fascismo le devuelve de sí misma, se encaminan a su propia destrucción. Ya en Simmel, esta percepción que no dimensiona el poder agente de las cosas es atendida: "Las cosas (...) nos hablan como desde lejos y la realidad se da en ellas no con seguridad inmediata, sino como entrevelada (...) Aquí aumenta todavía más la distancia que el arte, como tal, establece entre las cosas y nosotros" (1976, pp. 598-599). 


\subsection{Consideraciones finales: el aporte de Simmel}

Habiendo analizado la forma en que la problemática del crecimiento de la dimensión estética en nuestras vidas aparece en algunos de los escritos de Simmel, y dado que estamos pensando a Simmel como un antecesor del diagnóstico benjaminiano de una estetización de la política en manos del fascismo, analizaremos ahora la valoración de Simmel de este proceso y el aporte que puede ofrecer en el marco de nuestro estudio.

Nos interesa apartarnos, en primer lugar, de las interpretaciones que sostienen que Simmel cae víctima, él mismo, del proceso estetizante, estructurando su propia relación con la sociedad -en tanto pensador- en función de criterios estéticos. En este sentido, si bien compartimos con Frisby, como hemos argumentado, que la cuestión de la distancia está entre las preocupaciones sociológicas centrales de Simmel (Frisby, 1992b, p. 84), consideramos innecesario interpretar esta distancia como "parte de una distancia mucho mayor que Simmel mismo mantiene con su objeto" (Frisby, 1992b, p. 84). De igual manera, y si bien compartimos con este autor que la distancia que Simmel vislumbra es "la postura de la estetización de la realidad" (Frisby, 1992b, p. 84), no lo seguimos cuando afirma que esa distancia estetizante haya formado parte de la mirada de Simmel.

Frisby mismo, en el marco del "debate que rodea el esteticismo de Simmel” (1992b, p. 85), se posiciona en alguna medida entre aquellos que creen que su metodología "concuerda totalmente con la estetización de la realidad" (1992b, p. 88). Contrariamente, y si bien este debate no resulta central para nuestra argumentación, creemos que, si bien no hay en su obra un diagnóstico como el benjaminiano, el sociólogo y filósofo alemán observa muy agudamente el proceso que años más tarde denunciará Benjamin y está lejos de caer él mismo en una estetización del mundo social. Es posible, incluso, encontrar elementos en sus escritos que 
permiten observar una crítica del modo moderno de relación con el entorno y de su deriva contemplativa.

Lejos que tener una "concepción estética de la realidad" (Frisby, 1992b, p. 73), Simmel despliega su análisis muchas veces en la dirección del descubrimiento de configuraciones estéticas, en cuanto está convencido de la importancia de relevarlas, y permite, con el tipo de estudio que le es propio, delinear los contornos de este problema, mostrándolo. Este mérito no es menor, en tanto la filosofía ha lidiado y lidia aun con la búsqueda de formas que le permitan dar cuenta de los modos de experiencia que le son contemporáneos ${ }^{72}$, y el aporte de Simmel es, en este sentido, muy valioso, no sólo en lo que respecta al modo de exposición o el estilo, sino también, y como ya hemos mencionado, con respecto al recorte de los temas y los problemas. En este marco, el énfasis de Simmel en lo estético se justifica, en tanto es la vía que le permite mostrar modos típicamente modernos de configuración de la percepción y la atención, cuyo derrotero llega hasta nuestros días y cuyos peligros y potencialidades se siguen discutiendo. El mismo Frisby sostiene, en otro lado, que Simmel fue capaz de revelar y analizar constelaciones y configuraciones estéticas que existen -y se ocultan- en la superficie de la vida cotidiana (Frisby, 1992a, p. 136).

En este sentido, si bien su atención a la exposición -que une su estilo con el benjaminiano- puede pensarse como una forma de estilizar o embellecer en algún sentido el discurso científico, que se acerca por momentos a géneros más literarios, por otro lado, un rasgo de su modo de operar lo mantiene, a nuestros ojos, a salvo de la acusación de poner en marcha una estetización del mundo: al no tener una visión global de la realidad, Simmel no ve al mundo desde una posición de exterioridad, distanciado, como un mero paisaje. Como profundizaremos en el capítulo 7, lejos de un mecanismo estetizante, esta aproximación a los fenómenos es una forma de oposición al discurso totalizante de lo social.

${ }^{72}$ Volveremos sobre este tema en el capítulo 7. 
Mientras que otros sociólogos -y filósofos- trataron de aprehender el todo y de pintarlo en su obra, "lo que le interesó a él son los aspectos particulares de la totalidad de la sociedad y nunca esa totalidad en sí misma" (Frisby, 1992b, p. 93). Al fragmentar la realidad de un modo nuevo, iluminando y ampliando partes y aspectos hasta el momento invisibles, el pensador deconstruye la visión totalitaria que hace de la sociedad un todo cerrado que puede captarse en una imagen completa y llega incluso a afirmar que no hay algo así como la sociedad como tal, planteando que es un error tratar a una mera abstracción como si fuera algo real (De la Fuente, 2008, p. 347). Además, en su carácter de “pensador del quizás” [Vielleichtdenker] como lo llamó Bloch (citado por Frisby, 1992b, p. 99), evitó presentar un cuadro acabado de lo social o una teoría terminada que explicara el todo social sin grietas ni saltos, y eligió, como Benjamin, el sinuoso camino del mostrar. En este sentido se expresa también Lukács, para quien el impresionismo de Simmel (citado por Frisby, 1992b, p. 94) late siempre en ese trabajar con fragmentos - con la lógica del montaje- en lugar de ofrecer una representación acabada del mundo. Asimismo, es más matizada la tesis de Meyer (2018, p. 136), para quien lo que Simmel realiza es una sociología guiada estéticamente.

De todos modos, como cualquier autor que escriba acerca de su propia época, Simmel fue a la vez un observador y un participante de los fenómenos que registró. La distancia a la que se refiere, y que es parte del modo de vida que se configura en la economía dineraria, no puede ser sorteada simplemente por la voluntad de hacerlo. El caso del arte naturalista es, en este sentido, un buen ejemplo. En palabras de Simmel, su "sentido exclusivo parecería ser la abolición de la distancia que media entre nosotros y la realidad” (1976, p. 597), pero olvidó que "él también es un estilo, es decir, que también él ordena y transforma la inmediatez de la impresión merced a determinados presupuestos y exigencias" (1976, p. 597). Finalmente, en esa tensión, 
fue un intento desesperado por superar la distancia, por atrapar la cercanía y la inmediatez de las cosas. Pero tan pronto como uno se acerca, los nervios sensibles ya no pueden soportar el contacto y se alejan, como si hubieran agarrado brasas al rojo vivo. (Frisby, 1992b, p. 91)

Como desarrollaremos para el caso de Benjamin, oponerse a la tendencia estetizante no es fácil, y el arte debe tener la fuerza necesaria para romper esa distancia, impactando en el espectador de modo que éste no logre activar el mecanismo defensivo, pero evitando asimismo sensibilizar recurriendo al morbo (Melamed, 2005, p. 173). Este último punto es muy relevante, sobre todo teniendo en cuenta tentativas como de la estética de lo hiperreal, que siguiendo a Melamed, "anula toda sensibilidad y toda capacidad reflexiva, es un mazazo para el espectador y sencillamente constituye una forma sofisticada del fascismo contemporáneo: la pretensión de conmover a los golpes” (2010, p. 154). En Benjamin, la metáfora del arte como proyectil, que usa para hablar del surrealismo, da cuenta de esta acción que el arte debe poner en marcha y que es, como argumentaremos, su politización.

Por último, cabe observar que, salvando distancias históricas, esta imagen, tan potente, del arte como proyectil, aparece prefigurada en la obra de Simmel: "los nervios agotados, oscilando entre la hipersensibilidad y la indiferencia, solo pueden ser nuevamente excitados por la forma más ofuscada y la proximidad más terrenal, por los estímulos más sensibles y crudos" (Simmel, citado por Frisby, 1992b, p. 91).

En el marco de nuestro estudio, y si bien Simmel, como se mencionó, no se refiere específicamente a una "estetización de la política" ni a una "estetización de la vida cotidiana" ni, mucho menos, a un capitalismo creativo, sus ideas aportan dos elementos que nos interesa destacar a modo de conclusión.

En primer lugar, Simmel describió el cambio de época que significó el cambio de siglo de una manera brillante, y sus observaciones tienen la capacidad de dar cuenta de aquello que en una teoría de la sociedad como tal no emerge. Dado que esta época es la que ve nacer a 
Walter Benjamin -y a Martin Heidegger-y en la que se prefiguran algunos aspectos del capitalismo y de las nuevas subjetividades que tematizará el berlinés en sus escritos, estas observaciones resultan de suma importancia para contextualizar y complementar las de Benjamin. A su vez, como mencionamos y como sostuvo Richter,

la combinación de artículos, ensayos y libros; la combinación de notas, aforismos y trabajos enciclopédicos ocasionales; la inclusión de formas literarias en el espectro de medios de presentación y el uso de medios literarios acorde con los objetivos en contextos teórico-filosóficos fue una expresión del intento de combinar un espectro sensorial ampliamente abierto a una experiencia contemporánea con un pensamiento filosófico y teórico que se resiste a la osificación. (Richter, 2007, pp. 4-5, citado por Castillo)

En segundo lugar, y dado que en nuestro caso el concepto de estetización será analizado en su alcance político, como una forma no inocente de organizar la experiencia que, en conexión con una cierta invitación a una postura anestesiada de los colectivos, se presenta como una forma de despolitización, Simmel resulta un antecedente relevante. Si bien no enuncia las cosas de este modo, presenta varios elementos fundamentales para la comprensión del fenómeno que nos ocupa: en sus escritos da cuenta de cómo el sujeto se torna pasivo, las cosas se distancian y la realidad comienza a ser percibida como imagen. Simmel vislumbra la potencialidad del arte como aparato que moldea nuestra subjetividad y nuestra forma de ver el mundo y, lejos de entender este hecho de manera inocente, lo liga con un proceso en el que el mundo se nos aleja y se convierte en imagen, en el cual el valor de uso de las cosas deja de tener prelación y el valor de cambio -en la economía dineraria- y el valor de exposición resultan centrales. Por todo esto y como menciona Brett Wheeler, con Simmel emerge "un grupo de sociólogos y críticos sociales que estaban entre los observadores más agudos y los críticos más perspicaces del rol de la estética en 'reencantar el mundo"” (Wheeler, 2002, 114). 


\section{Capítulo 3}

\section{El problema de la estetización en Walter Benjamin ${ }^{73}$}

\subsection{Introducción}

En el epílogo de su célebre ensayo sobre la obra de arte, Benjamin observa:

La humanidad, que fue una vez, en Homero, un objeto de contemplación [Schauobjekt] para los dioses olímpicos, se ha vuelto ahora objeto de contemplación para sí misma. Su autoenajenación [Selbstentfremdung] ha alcanzado un grado tal que le permite vivir su propia aniquilación [Vernichtung] como un goce estético de primer orden [ästhetischen Genuß ersten Ranges]. (Benjamin, 2015b, p. 67)

Así describe el fenómeno de la estetización de la política [̈̈sthetisierung der Politik], al cual, según sus propias palabras, “el comunismo le responde con la politización del arte [Politisierung der Kunst]" (Benjamin, 2015b, p. 67) ${ }^{74}$.

En este capítulo, después de haber reconstruido en los precedentes algunos usos y sentidos posibles del concepto de estetización - por un lado, con énfasis en los debates actuales $y$, por el otro, en la prefiguración de la estetización como motivo en Simmel- nos centraremos en la filosofía de Benjamin, e intentaremos dar cuenta del modo en que el diagnóstico de una relación estetizante con el mundo impregna sus reflexiones más allá del ensayo sobre la obra de arte.

\footnotetext{
${ }^{73}$ Una versión previa de este capítulo (Staroselsky, 2018) fue publicada en la Dianoia. Revista de Filosofía.

${ }^{74}$ Steiner (2001) ha sostenido que este pasaje podría ser leído como indicando, no tanto un antagonismo teóricamente convincente, sino más bien una proximidad entre estas dos operaciones, que indicaría la necesidad de evitarlas a ambas (p. 87). En nuestro caso, nos alejaremos de esta lectura.
} 
En el universo de las recepciones e interpretaciones de la obra de Benjamin, el concepto de estetización no ha sido objeto, por lo general, de un tratamiento exhaustivo, más allá de las lecturas, vastas y variadas, del ensayo sobre la obra de arte. Aun así, y como sostendremos, este concepto, y especialmente su articulación en torno a la denuncia de una estetización de la política en el nazismo, merece un lugar central en la reconstrucción del pensamiento del autor, junto a conceptos como el de experiencia o el de aura, cuya importancia es ampliamente reconocida. Entre los comentadores que han destacado la importancia de la idea de estetización, cabe destacar a Koepnick, para quien este motivo "podría, de hecho, terminar resultando, hoy y en el futuro, uno de los legados más perdurables de la teoría crítica alemana" (Koepnick, 1999, p. 26).

En nuestro caso, argumentaremos que el concepto de estetización es central por dos motivos de diferente naturaleza. Por un lado, por su actualidad: a partir de la formulación de Benjamin han surgido múltiples debates acerca de la estetización como problema, y sus aportes resultan, aún hoy, productivos para pensar nuestra relación con el mundo. Por otro lado, porque el concepto de estetización, en tanto puede ser comprendido, en la obra de Benjamin y como argumentaremos, como la contracara del concepto de experiencia -en el sentido de Erfahrung, se encuentra en el corazón de sus reflexiones sobre el arte y la historia, pero es relevante, también, para comprender cómo pensó la tarea de la filosofía y en general el rol de los intelectuales y artistas.

El objetivo de este capítulo, en este marco, es ofrecer una reconstrucción de la concepción benjaminiana de la estetización. Para eso, organizaremos la exposición en torno a dos apartados: en el primero, reconstruiremos la crítica de Benjamin a la estetización de la política presente en "La obra de arte en la época de su reproductibilidad técnica"; en el segundo, sostendremos que el diagnóstico de una estetización no es exclusivo, en el marco de la filosofía de Benjamin, del ámbito del arte y de su relación con la política, sino que encuentra arraigo 
también en el ámbito de la historia, en la forma de una estetización del pasado a la que Benjamin, sobre todo en las Tesis "Sobre el concepto de historia", propone responder con la politización de la historia (Naishtat, 2008) $)^{75}$. En las dos exposiciones nos remitiremos al concepto de experiencia [Erfahrung], en la medida en que resulta una clave interpretativa fructífera para comprender y acercar las propuestas de Benjamin en ambos contextos: en efecto, la oposición a la estetización de la política será, como es sabido, la politización del arte, como tarea que implica hacer una experiencia con las nuevas manifestaciones artísticas tras el derrumbe del arte aurático; por su parte, la relación estetizante con el pasado será evitada, en el materialismo histórico que propone Benjamin, mediante la tarea explícitamente enunciada de hacer una experiencia con el pasado. En ambos casos, la mera contemplación pasiva ${ }^{76}$ se contrapone a la necesidad de hacer una experiencia, esto es, de elaborar de manera activa y colectiva la relación con el pasado, así como la relación con el arte y los bienes culturales.

\subsection{Estetización de la política o politización del arte}

Pero también había algo en esa técnica abocetada que se fundía a la perfección con el tema: como si el artista hubiese sido interrumpido por un terremoto en medio del trabajo, como si en un mundo precario terminar algo ya no tuviera sentido.

María Gainza, 2017, p. 73

\footnotetext{
${ }^{75}$ Esta problematización del motivo de la estetización en torno al pasado se gestó en diversos diálogos con el Dr. Francisco Naishtat, quien trabajó acerca del primado de la política sobre la historia en la Obra de los pasajes (Naishtat, 2008) y a quien agradezco por sus valiosos comentarios al respecto. Tuve oportunidad de discutir sobre este tema con Francisco en varias oportunidades, y centralmente durante el seminario que dictó en la UBA junto a la Dra. Florencia Abadi en el 2014 centrado en la filosofía de Benjamin.

${ }^{76}$ La pasividad de la contemplación se ha puesto en duda en la filosofía contemporánea (por ejemplo, por Rancière, 2010). Asimismo, la estética de la recepción, que Benjamin en alguna medida anticipa (cfr. Presas, 2013; Jauss, 1986), ha atribuido ya desde los años sesenta del siglo XX un papel activo de cocreación al espectador o receptor de la obra. Aun así, la redefinición que Benjamin elabora del concepto de experiencia y su desplazamiento radical del par sujeto-objeto para pensar la relación del hombre con el mundo excede a sus reflexiones sobre el arte y las enmarca en un cuestionamiento del modo de pensar de la filosofía tradicional.
} 
La célebre expresión "estetización de la política" aparece en el epílogo de "La obra de arte en la época de su reproductibilidad técnica", donde Benjamin analiza el impacto de los medios técnicos de reproducción, en especial, de la fotografía y del cine, en el arte y en la percepción, y se propone de manera explícita dejar de lado las concepciones estéticas heredadas para introducir en la teoría del arte conceptos "completamente inutilizables para los fines del fascismo [für die Zwecke des Faschismus vollkommen unbrauchbar]" (Benjamin, 2015b, p. 26), en tanto "son, en cambio, utilizables en la formulación de exigencias revolucionarias en la política artística [zur Formulierung revolutionärer Forderungen in der Kunstpolitik brauchbar]" (Benjamin, 2015b, p. 26).

Detengámonos en este ensayo $\mathrm{y}$, específicamente, en uno de los conceptos más relevantes para su interpretación: el de aura. Benjamin da cuenta en este texto de cómo los rasgos que caracterizaban a la obra de arte en su forma tradicional, la unicidad [das Hier und Jetzt] y la autenticidad [Echtheit] que ella compone, se encuentran amenazados por la reproductibilidad propia de las nuevas producciones artísticas, cuyas copias cancelan todo sentido de la pregunta por el original. En efecto, y si bien siempre hubo reproducciones de las obras de arte, en la época de la reproductibilidad técnica las mismas no se encuentran ya degradadas con respecto a un original, pues este, la obra de arte aurática que mantenía "su plena autoridad frente [seine volle Autorität] a la reproducción” (Benjamin, 2015b, p. 29), está ausente.

El concepto de aura es, como muchos -si no todos- los conceptos que pueblan la producción benjaminiana, muy difícil de definir ${ }^{77}$. No es casual que tanto Josef Fürnkäs, autor de la entrada "Aura" del estudio Conceptos de Walter Benjamin (2014), como Miriam Hansen (2007), quien le dedica un muy interesante artículo, den cuenta de este rasgo: para el primero,

\footnotetext{
${ }^{77}$ Berti (2015) caracteriza al aura benjaminiana como "una categoría multivalente que orienta los análisis de diversos objetos y fenómenos culturales en su obra teórica" y sostiene que es por eso "sumamente discutible, cuando no imposible, aspirar a una síntesis definitoria y unívoca" (p. 206).
} 
"los conceptos de Benjamin no aclaran nada. Se encuentran, antes bien, altamente necesitados de esclarecimiento" (Fürnkäs, 2014, pp. 88-89). Fürnkäs sostiene, sin embargo y específicamente sobre el concepto de aura, que "hay que descartar el argumento según el cual, con el concepto impreciso de aura, se corresponde la imprecisión del concepto designado" (2014, p. 84). En efecto, no es la precisión lo que está en juego: los conceptos en Benjamin no son esquivos por estar mal delimitados, sino, en muchos casos, porque son habitados por complejidades y tensiones que se resisten a ser incorporados en una definición taxativa. Para Hansen, en esta línea, el concepto de aura, lejos de ser estable y delimitable, "describe un grupo de significados y relaciones que aparecen en los escritos de Benjamin en varias configuraciones y no siempre bajo su propio nombre" (2007, p. 339), pero es justamente, aclara la autora, "esta fluidez conceptual la que permite que el aura se convierta en un punto nodal tan productivo en el pensamiento de Benjamin” (2007, p. 339).

Las caracterizaciones del aura que surgen de los textos de Benjamin son dos. Por un lado, en el texto que nos ocupa y en su "Pequeña historia de la fotografía", el berlinés presenta al aura como "aparecimiento único de una lejanía, por cercana que pueda estar [einmalige Erscheinung einer Ferne, so nah sie sein mag]" (Benjamin, 2015b, p. 31; GS I 440) ${ }^{78}$. Por el otro, la definición que se esboza en "Sobre algunos motivos en Baudelaire" apunta al modo en que el ser humano dota a un fenómeno de la capacidad de alzar la vista y devolver la mirada: "Experimentar el aura de una aparición [Die Aura einer Erscheinung erfahren]" -dirá Benjamin- "significa investirla con la capacidad de ese alzar la mirada [heißt, sie mit dem

\footnotetext{
${ }^{78}$ La definición presenta diferencias menores entre la primera y la segunda redacción, por un lado, y la tercera versión del ensayo, por otro. En la primera y segunda redacción, la definición completa caracteriza al aura como "un entretejido muy especial de espacio y tiempo: aparecimiento único de una lejanía, por cercana que pueda estar" [Ein sonderbares Gespinst aus Raum und Zeit: einmalige Erscheinung einer Ferne, so nah sie sein mag] (GS I 440; GS VII 355). En la tercera versión, la primera parte no aparece y Benjamin solo escribe "aparecimiento único de una lejanía, por cercana que pueda estar" (GS I 479). A su vez, la definición completa de la primera redacción del ensayo sobre la obra de arte reaparece en "Kleine Geschichte der Photographie" (GS II 378).
} 
Vermögen belehnen, den Blick aufzuschlagen]" (2008c, p. 253; GS I 646-647). Se trata, en todos los casos, de textos que ven la luz en la década del 30.

Cabe destacar que, como menciona Fürnkäs, si bien "por un lado, la expresión 'aura' solo a partir de Benjamin alcanza una importancia filosófica; por otro, no representa una creación conceptual de Benjamin, sino que funciona como cita de la tradición mística" (2014, p. 94). Hansen da cuenta de que, más allá de las definiciones, que aparecerán algo después, el primer uso de esta noción en la obra de Benjamin se da en "un reporte no publicado sobre uno de sus experimentos con el hachís datado en marzo de 1930” (2012, p. 336). Allí, Benjamin entabla una polémica con los teósofos, y sostiene que "el aura auténtica viene a aparecer en toda cosa [erscheint die echte Aura an allen Dingen], y no sólo en algunas, como la gente suele imaginar [nicht nur an bestimmten, wie die Leute sich einbilden]" (Benjamin, 2017a, p. 774; GS VI 588). Hansen observa a raíz de este reporte que

esta afirmación contrasta fuertemente con la comprensión habitual del aura en Benjamin como una categoría principalmente estética, como abreviatura de las cualidades particulares del arte tradicional que él observó menguando en la modernidad, asociadas con el estado singular de la obra de arte: su autoridad, autenticidad e inalcanzabilidad, resumidas por la idea de la bella apariencia. (Hansen, 2012, p. 336)

Consideramos que las interpretaciones de Hansen y Fürnkäs en este sentido son apropiadas: Benjamin no utiliza el concepto de aura en la década del 20 para no acercarse demasiado al uso oscurantista de los teósofos y para "evitar una afinidad demasiado ostentosa con el grupo de cósmicos de Múnich" (Fürnkäs, 2014, p. 97), de quienes lo separaban diferencias importantes. Estas formas de la mística representan -Benjamin lo pondrá en palabras en los 30, especialmente en "Experiencia y pobreza"-, intentos desesperados de 
reencantar un mundo en descomposición, en una clara negación del presente y las posibilidades que le son propias.

Este debate, que no recuperaremos aquí, es de todos modos importante en tanto revela un hecho:

Las grandes dificultades para captar el concepto benjaminiano de aura deben remontarse a que pertenece esencialmente a dicho término -tanto en el aspecto del signo como también en el de lo designado- el hecho de sustraerse a la claridad filosófica esperada. (Fürnkäs, p. 95)

El uso, por parte de Benjamin, de un concepto usado por aquella "ciencia oculta que se dispone a unir en forma monista teología y estética" (Fürnkäs, 2014, p. 97) supone y hasta asume una complejidad conceptual que sería imposible resolver por la vía analítica.

En la polémica contra los teósofos tal y como aparece en el texto de marzo de 1930, Benjamin enfatiza tres cosas acerca del aura. En primer lugar, el hecho de que aparece en todas las cosas, como ya mencionamos. Sin embargo, eso no es todo, y si bien Benjamin mismo anota que lo que dijo en aquella ocasión sobre el aura "poseía un polémico vértice dirigido a los teósofos" (2017a, p. 773) y no estaba planteado "ciertamente de una manera exacta y esquemática" (2017a, p. 773), es interesante atender a sus palabras:

En segundo lugar, el aura viene a modificarse por entero y bien a fondo a cada movimiento de la cosa cuya aura es [ändert sich die Aura durchaus und von Grund auf mit jeder Bewegung, die das Ding macht, dessen Aura sie ist]. En tercer lugar, el aura auténtica [die echte Aura] no se puede pensar en modo alguno como ese nimbo espiritualista tan relamido [geleckte spiritualistische Strahlenzauber] que se nos describe en los libros místicos vulgares. Lo que más bien distingue al aura auténtica es precisamente el ornamento [das Ornament], halo ornamental donde la cosa o esencia está hundida como estando instalada dentro de una funda [eine 
ornamentale Umzirkung in der das Ding oder Wesen fest wie in einem Futteral eingesenkt liegt]. (Benjamin, 2017a, p. 774; GS VI 588)

Al hablar del aura, en efecto, Benjamin no se refiere a algo en sí que sale de los objetos, sino siempre, más bien, al producto de una experiencia, esto es, de una interacción. El arte aurático, así, es un arte caracterizado por un tipo específico de experiencia que está dejando de ser posible dadas las nuevas condiciones materiales de la producción y la recepción de arte. Es así que la crisis de la experiencia y la crisis del arte aurático están emparentadas en tanto formas de constatar el fin de una misma forma de relacionarse con el mundo, que en un caso se presenta en el análisis de la obra de arte, y en otro se observa en contextos más amplios.

El diagnóstico que Benjamin presenta en "Pequeña historia de la fotografía" es en este sentido relevante. Allí, Benjamin constata la presencia de un aura artificial, en tanto los fotógrafos vieron como su tare a simular el aura por medio del retoque ["diese Aura durch alle Künste der Retusche (...) vorzutäuschen”] (GS II 733), lo que revela un síntoma: la desaparición de aquello a lo que la fotografía se aferra de modo artificial. Es así que "esta aura (...) da indirectamente testimonio de la decadencia de aquella aura" (Fürnkäs, 2014, p. 109). Contra ese gesto conservador de los fotógrafos, Benjamin celebra la actitud de Atget, quien liquida el aura, libera a los objetos de ella, y asume así las pobrezas propias de su tiempo.

Si bien mucho se ha discutido sobre el concepto de aura y su alcance en la obra de Benjamin, el rasgo del arte aurático que nunca se pone en duda es el de la irrepetibilidad. Bolívar Echeverría lo explica bien cuando dice que:

El aura de una obra humana consiste en el carácter irrepetible y perenne de su unicidad o singularidad, carácter que proviene del hecho de que lo valioso en ella reside en que fue el lugar en el que, en un momento único, aconteció una epifanía o revelación de lo sobrenatural que perdura metonímicamente en ella y a la que es posible acercarse mediante un ritual determinado. Por esta razón la obra de arte aurática, en la que prevalece el "valor para el culto", sólo puede ser una obra 
auténtica; no admite copia alguna de sí misma. Toda reproducción de ella es una profanación $^{79}$. (2003, p. 16)

Con la aparición de manifestaciones como la fotografía, donde la reproducción, lejos de ser una profanación, es constitutiva de la obra, la experiencia estética tal y como resultaba familiar, es decir, ligada fuertemente al carácter aurático de la obra y atada al valor de culto del original que emanaba de su presencia irrepetible, deja de ser posible. La nueva técnica reproductiva, "al multiplicar sus reproducciones pone, en lugar de su aparecimiento único, su aparecimiento masivo [setzt sie an die Stelle seines einmaligen Vorkommens sein massenweises]" (Benjamin, 2015b, p. 30; GS I 477). Con este movimiento, la reproducción mecanizada de la obra de arte modifica la relación de las masas con el arte al ampliar el círculo de difusión de las obras, aun al costo de hacer peligrar la experiencia estética tradicional ${ }^{80}$.

Ahora bien, ante el proceso de desvanecimiento histórico del aura, y como se constata ya en algunas fotografías y en el renacer de ciertos espiritismos, surge una reacción nostálgica de restauración, que Benjamin encuentra en la teoría del arte por el arte y en la que es interesante detenerse. Fürnkäs se refiere a dos movimientos que Benjamin pone en juego respecto del aura: por un lado, la constatación y la descripción de su decadencia histórica y,

\footnotetext{
79 En Profanaciones (2005), Agamben define "sacralizar" como sustraer "al libre uso y al comercio de los hombres" (p. 97), y entiende que esta operación es propia de la sociedad actual en tanto museificada. El opuesto que propone es la operación de profanación, en tanto restitución de las cosas "al libre uso de los hombres" (p. 97). A su vez, el mismo Benjamin refiere, en un fragmento no publicado que dataría de 1931 o 1932, unas palabras de Franz Glück sobre Adolf Loos, en torno a los barcos en botellas. Allí, Glück narra: "Mientras iba leyendo las palabras de Goethe en que se reprueba la manera en la que igualmente los incultos, como muchos expertos en el arte, palpan aguafuertes y relieves, vino a entender que lo que hay que tocar no puede ser una obra de arte, y que lo que es obra de arte ha de sustraerse a ese contacto" (citado por Benjamin, 2017e, p. 164). Benjamin, tras la cita, comenta: "Los objetos que guarda la botella, ¿son por tanto quizá obras de arte al sustraerlas a la manipulación?" (2017e, p. 165).

${ }^{80} \mathrm{La}$ mirada por momentos ambivalente de Benjamin ante el fin del arte aurático ha sido ampliamente señalada. En efecto, y como sucede con todas las constataciones benjaminianas de una ruptura de la tradición, el recibimiento de lo nuevo no es siempre alegre, y está marcado por la conciencia de las potencialidades y los peligros que entrañan las profundas modificaciones que trae el nuevo siglo. En este sentido, por momentos pareciera que "Benjamin trata de convencerse a sí mismo y de convencer a sus lectores de que la manera en que la experiencia estética se ha alcanzado gracias a la obra de arte aurática está por ser sustituida por una manera mejor, más libre, de hacerlo, una manera capaz incluso de redefinir la noción misma de lo estético" (Echeverría, 2003, p. 17). Hansen refiere también al modo en que Benjamin se debatía entre "los extremos del vanguardismo revolucionario y el duelo elegíaco por la bella apariencia" (2007, p. 338).
} 
por el otro, el llamado a la acción, la "profesión vanguardista de la necesidad de su demolición" (Fürnkäs, 2014, p. 87), que responde justamente a la "tentativa para conservar el aura de manera sentimental" (Fürnkäs, 2014, p. 151) que los cambios históricos despiertan. Fürnkäs utiliza el concepto de "pseudoaura" para hablar de la restauración del aura y explica lo irreversible de su decadencia en Benjamin como hecho histórico ${ }^{81}$. Hansen, por su parte, y si bien comparte con Fürnkäs que Benjamin parece distinguir entre el aura que desaparece y aquella que llama a destruir, considera "que la fuerza de esta llamada no puede sino golpear, también, al aura 'genuina'” (Hansen, 2007, p. 356).

En efecto, los intentos por conservar el aura parecen ignorar algo que para Benjamin resulta claro: que auratizar o desauratizar la obra de arte no son decisiones estéticas que el artista tenga a la mano. Tras las profundas transformaciones en la experiencia y en los modos de vida, las opciones se limitan a aceptar la ruptura con la tradición ${ }^{82}$ y trabajar con este desvanecimiento de la experiencia aurática de la obra de arte o, de una manera conservadora, aferrarse a ella a costa de su falsificación. El llamado de Benjamin a evitar la caída en esta nostalgia conservadora, su llamado a la acción y a la destrucción, conecta este texto con "Experiencia y pobreza". Al respecto sostiene Hansen:

en ese sentido, el ensayo sobre la obra de arte debería ser visto como un experimento desesperado, una apuesta existencial comparable con la tabula rasa propuesta en "Experiencia y pobreza" tres años antes, habiendo aumentado exponencialmente los riesgos con el oscurecimiento de la situación política $-\mathrm{y}$ de la situación personal de Benjamin-. (2007, p. 356)

\footnotetext{
${ }^{81}$ También Hansen se refiere a "la simulación de los efectos auráticos" como por ejemplo en el "culto a las estrellas [star cult] de Hollywood" (2007, p. 336).

${ }^{82}$ Tomamos la expresión de Amengual: "Lo que queda claro es que con la pérdida de la experiencia se pierde, no un elemento cognitivo cualquiera, sino la capacidad de percibir lo que se vive, la capacidad de integrarlo en la vida, de compartirlo con los demás y de transmitirlo. La pérdida de la experiencia apunta, entonces [. . .] a la ruptura con las formas de vida y de pensar practicadas a lo largo de los siglos, ruptura, por tanto, de una forma de vida histórica; señala una ruptura de la tradición" (Amengual, 2008, p. 57).
} 
En efecto, el paralelismo con los postulados de "Experiencia y pobreza"83 es claro: allí, Benjamin celebra a aquellos, como Brecht o Loos, como Klee o Scheerbart, cuyo "rasgo más característico es la total falta de ilusiones sobre nuestra época y, junto con ello, su entera aceptación, sin abrigar reservas frente a ella [gänzliche Illusionslosigkeit über das Zeitalter und dennoch ein rückhaltloses Bekenntnis zu ihm ist ihr Kennzeichen]" (Benjamin, 2007a, p. 219; GS II 216) y se aleja, citando la proclama de Loos, de las "personas que se consumen en el anhelo del Renacimiento o el rococó [Menschen, die sich in Sehnsucht nach der Renaissance oder dem Rokoko verzehren]" (Benjamin, 2007a, p. 219; GS II 216). De lo que se trata no es de una fetichización de la técnica ni de la modernidad, de un ensalzar la velocidad de los cambios y de lo nuevo ni del desprecio de lo pasado. Contrariamente, lo que Benjamin está pidiendo con respecto a la época es su aceptación como momento ineludible para su análisis, su lectura, su crítica. El escape a formas premodernas de sentir y de percibir representa, para el autor, un peligro.

El núcleo de este texto de 1933 -en el que nos centraremos en el próximo capítulo- es la pobreza de experiencia y la miseria enteramente nueva que se precipitó sobre los hombres tras la guerra y el despliegue formidable de la técnica. Esta peculiar situación social y cultural implica una ruptura abrupta con la tradición y con los sentidos hasta el momento compartidos, que pierden el poder que supieron tener de mantener unido el tejido social. El reverso de esta pobreza, la reacción ante ella, de la que Benjamin se aleja, será su no aceptación, que impide trabajar con ella como realidad histórica y que se manifiesta, por caso, en la proliferación de nuevos modos de espiritismo, respecto de los cuales dice Benjamin: "aquí no ha tenido lugar una verdadera reanimación [echte Wiederbelebung], sino una forma de galvanización [Galvanisierung]” (Benjamin, 2007a, p. 218; GS II 215).

\footnotetext{
${ }^{83}$ Abordaremos en profundidad este texto, y el concepto de experiencia, en el capítulo 4.
} 
La galvanización, que en biología y en medicina se refiere a un proceso de estimulación artificial de los músculos o nervios mediante corrientes eléctricas, supone la reactivación súbita $\mathrm{y}$ artificial de alguna actividad o sentimiento humano. En el caso del arte, y aunque Benjamin no vuelve a recurrir a este término, también es posible observar una reactivación nostálgica de algo perdido, que contrasta con la aceptación de su final. Los intentos de reauratización del arte, de galvanización del misterio que otrora anidaba en la obra y que la abandonó, son estériles para Benjamin, y acarrean incluso peligros en el ámbito político: al no aceptar la democratización del arte ni los cambios en sus modos de producción, circulación y recepción, la actitud nostálgica se posiciona a favor de un mundo en descomposición y puja por revivir un orden en crisis que está muy lejos de identificarse con un pasado feliz.

La estetización de la política será resultado, en parte, de esa reacción conservadora ante los cambios que atraviesa el arte, encarnada en quienes defienden un "concepto fetichista y antitécnico de arte" [fetischistische, von Grund auf antitechnische Begriff von Kunst]"84 (Benjamin, 2007e, p. 380; GS II 269) al que Benjamin se refiere y del que se aleja en su "Pequeña historia de la fotografía" $"$. Koepnick, en este mismo sentido, señala que

la estetización intenta, precariamente, conciliar aquello que parece haberse roto en pedazos en la modernidad. Emprende una restauración de la autenticidad emocional y la experiencia no alienada, y al hacerlo espera contrarrestar la desintegración de la sociedad moderna en un campo minado de conflictos sociales, económicos y políticos. (Koepnick, 1999, p. 33)

\footnotetext{
${ }^{84}$ Como hemos mencionado en la Introducción a esta sección, un representante de la idea antitécnica del arte es Baudelaire, quien en su breve texto "El público moderno y la fotografía" sostiene: "De día en día el arte disminuye el respeto a sí mismo (...) y el pintor se inclina más y más a pintar, no lo que sueña, sino lo que ve. Sin embargo, es una felicidad soñar, y era una gloria expresar lo que se soñaba; pero, ¡qué digo! ¿sigue conociendo esa felicidad? ¿Afirmará el observador de buena fe que la invasión de la fotografía y la gran locura industrial son por completo ajenas a ese deplorable resultado?" (1976, p. 279). Benjamin se refiere a este escrito en su propio trabajo sobre Baudelaire (2008c, pp. 250-251).

${ }^{85}$ Allí, Benjamin compara la invención de la fotografía con la de la imprenta. Compartimos con Carrasco que "un posible intento de aclarar esta relación nos lo proporciona La Galaxia Gutenberg, de Marshall McLuhan. En su brillante análisis de la incidencia histórica que supone la aparición y el desarrollo de la imprenta, McLuhan señala la importancia de la técnica como un agente decisivo en los procesos de reforma del entendimiento humano" (Carrasco, 2017, p. 159).
} 
Por su parte, respecto de la relación entre los intentos de restauración del arte aurático y la política, sostiene Federico Galende:

[E]n la época de la reproductibilidad técnica, es la reproducción misma lo que se eleva como una amenaza destructiva respecto de la modelación política obrada por esta fusión entre una 'teología del arte' y una autonomía estética que insiste en preservar el arte en la pureza de su esfera. (Galende, 2009, pp. 180-181)

Lejos de extinguirse de manera natural, entonces, los valores ligados por tradición al arte se resisten y encuentran sitio en otra práctica: la distancia contemplativa, el recogimiento y el valor cultual propios de la experiencia estética tradicional se mudan a la política y se convierten en su supuesto no político (Galende, 2009, p. 178). Como señala Benjamin, los conceptos heredados de la teoría del arte, "como creatividad y genialidad, valor imperecedero y misterio [wie Schöpfertum und Genialität, Ewigkeitswert und Geheimnis]" (Benjamin, 2015b, p. 26; GS I 473) ${ }^{86}$, así como el recogimiento y el sometimiento ante la obra de arte, resultan al fin, en su distorsión y su extrapolación a otros ámbitos, funcionales al fascismo.

En el contexto de la estetización de la política, es decir, en la transformación de la política en objeto de contemplación y goce, en algo que se valora con criterios estéticos -“la guerra es bella", dirá el futurista Filippo Tommaso Marinetti-, las masas se encuentran desdobladas. Susan Buck-Morss entiende la estetización de la política que lleva a cabo el fascismo como una nueva forma de alienación y observa:

\footnotetext{
${ }^{86}$ Esta es la enumeración que realiza Benjamin en el prefacio a la tercera versión del texto - que aparece ya en la segunda versión (GS VII 350)-, y que presenta diferencias respecto a la que plantea en la primera redacción. En esta incluye, además de la creatividad, la genialidad y el valor imperecedero [Schöpfertum und Genialität, Ewigkeitswert], el estilo, la forma y el contenido [Stil, Form und Inhalt] (GS VII 435), elementos que luego omite, y no se refiere al misterio o secreto que anida en la obra [Geheimnis], que suma a partir de la segunda versión y en la tercera (Benjamin, GS VII 350; GS I 473).
} 
[L]a propaganda fascista tuvo la genialidad de dar a las masas un papel doble: el de observador tanto como el de la masa inerte que es moldeada y configurada. Y sin embargo, debido a un desplazamiento del lugar del dolor, debido al consecuente falso (re)conocimiento, la masa-como-público no es perturbada por el espectáculo de su propia manipulación. (2015, p. 200)

Benjamin analiza varios aspectos de la estetización de la política algunos años antes de enunciarla como tal, en "Teorías del fascismo alemán" ["Theorien des deutschen Faschismus"], de $1930^{87}$. Se trata de una reseña crítica de Guerra y guerreros [Krieg und Krieger], una compilación de textos sobre la Primera Guerra Mundial coordinada por Ernst Jünger ese mismo año. Allí, Benjamin afirma que la exaltación de la guerra expresada en los textos del libro, más que una mera curiosidad, es un hecho que "revela un síntoma" (Benjamin, 2001a, p. 49; GS III 240). En consonancia con lo que dirá algunos años después en el ensayo sobre la obra de arte, Benjamin sostiene en este texto que "esta nueva teoría de la guerra, que tiene su origen rabiosamente decadente inscrito en la frente, no es más que una transposición descarada de la tesis de L'Art pour l'Art a la guerra [eine hemmungslose Übertragung der Thesen des L'Art pour l'Art auf den Krieg]" (Benjamin, 2001a, p. 49; GS III 240).

La estetización de la política es así, al mismo tiempo, su despolitización y se presenta como parte de una reacción nostálgica ante los cambios en los modos de vida, entre los cuales resultan esenciales las modificaciones en la percepción sobre las que Benjamin insiste más de una vez. En esta reacción conservadora -en palabras de Jürgen Habermas-, el arte fascista

se presenta con la pretensión de ser un arte político (...) Pero tras el velo de la politización, queda en realidad al servicio de una estetización de la pura violencia política (...) La magia cultual queda rota tan sólo para ser renovada sintéticamente. (Habermas, 1975, p. 302. El enfatizado es nuestro)

\footnotetext{
${ }^{87}$ Para una interpretación más exhaustiva del texto de Benjamin puede consultarse Hillach (1979).
} 
La respuesta de Benjamin a la estetización de la política será justamente la politización ${ }^{88}$ del arte, es decir, una modificación de la relación entre el público y los objetos artísticos que, como veremos, implica cambios no sólo en el sujeto, sino también en el modo de comprender el objeto mismo ${ }^{89}$. Y es que, como señala Didi-Huberman, "Benjamin descubre de inmediato que el componente fascista de este volumen va de la mano con una especie de estetización recurrente (...). Y, sin embargo -o por eso mismo- no dejará el arte y la imagen en manos de sus enemigos políticos" (2012b, p. 23). La politización del arte, el arrancar al arte de las manos de esos enemigos, implica aceptar la pérdida del aura y liquidar los valores ligados a ella, en un alejamiento radical de los intentos de restauración.

Un impulso claro en ese sentido se da con el dadaísmo, en el marco del cual los artistas construyen sus obras de arte asegurándose de su "inutilidad como objetos de recogimiento contemplativo [Unverwertbarkeit als Gegenstände kontemplativer Versenkung]" (Benjamin, 2015b, p. 62; GS I 501-502). “Con los dadaístas”-dirá el berlinés- "la obra de arte dejó de ser una visión cautivadora [einem lockenden Augenschein] o un conjunto de sonidos convincente [einem überredenden Klanggebilde], y se convirtió en un proyectil [Geschoß] que impactaba sobre el espectador [Es stieß dem Betrachter zu]. Alcanzó una cualidad táctil [eine taktile Qualität]" (Benjamin, 2015b, p. 62; GS I 502). La obra de arte se despoja de su aura que es también su envoltura y sale al encuentro del espectador, transformándolo y viéndose

\footnotetext{
${ }^{88}$ En torno al concepto benjaminiano de politización cabe mencionar el aporte de Ana Lanfranconi (2017) en su tesis doctoral, en la que recorre la obra de Benjamin y reconstruye la relación que se teje en su obra entre la infancia y la politización.

${ }^{89}$ Sobre la respuesta a la estetización de la política, Peter Fenves (2010) ha argumentado que, de hecho, no hay en Benjamin una tal respuesta. El autor sostiene que el ensayo de Benjamin toma su punto de partida del prefacio a la Crítica de la economía política de Marx, donde este autor argumenta que "la humanidad solo se plantea tareas que es capaz de resolver" (Marx, citado por Fenves, 2010, p. 76). Sobre esta base, Fenves considera que el texto de Benjamin se pregunta fundamentalmente si la humanidad puede resolver sus tareas autoasignadas, y retrotrae este problema a Kant y el motivo de la tarea infinita [unendliche Aufgabe]. "Toda respuesta definitiva a la estetización de la política" - argumenta Fenves- "confunde la tarea con un problema que puede resolverse de manera definitiva" (2010, p. 77), razón por la que no sería posible afirmar que hay una respuesta a ese problema. Por nuestra parte, no compartimos esta interpretación, en tanto en Benjamin ningún problema encuentra el tipo de respuesta definitiva que plantea Fenves. La politización del arte, lejos de ser una tarea de esa naturaleza, implica modificaciones -más o menos profundas- en la estructura de nuestra experiencia.
} 
transformada por él, mientras que hasta entonces lo que llamábamos arte sólo empezaba “a dos metros del cuerpo [Was wir Kunst nannten, beginnt erst zwei Meter vom Körper entfernt]" (Benjamin, 1998, p. 114; GS II 622).

Como es evidente en el fragmento sobre el dadaísmo, se elimina la distancia necesaria para la mirada contemplativa -esa que notaba ya Simmel-, y no de una manera metafórica, sino en términos físicos, pues la obra se traslada efectivamente y logra un impacto en el espectador, de manera que queda cancelada la barrera entre un sujeto fuerte y un objeto bien consolidado que aquél puede observar.

La importancia de las categorías espaciales en el ensayo sobre la obra de arte es en efecto, cabe mencionarlo, uno de los puntos en los que es posible encontrar la influencia de Simmel. Asimismo, y como recuerda Hansen, Benjamin retoma aportes de Riegl,

en particular la oposición entre distancia contemplativa y cercanía táctil, a lo largo del ensayo sobre la obra de arte, para revelar el carácter táctil del arte y el cine de vanguardia del siglo XX contra la fenomenal distancia del arte tradicional, aurático. (Hansen, 2007, pp. 352-353)

La politización del arte en Benjamin, por su parte, no se refiere al contenido de las obras y se aleja decididamente de un arte político de carácter propagandístico o pedagógico (Galende, 2009, p. 200). En cambio, se presenta como la modificación de la relación entre el espectador y la obra. La propuesta de que el arte sea un proyectil, de que salga de su emplazamiento y vaya al encuentro del espectador coincide con la idea de hacer del arte una experiencia. Como menciona Echeverría, Benjamin estaba "convencido de que, en la dimensión discursiva, lo político se juega —y de manera a veces incluso más decisiva — en escenarios aparentemente ajenos al de la política propiamente dicha” (Echeverría, 2003, p. 9), que proponemos tratar de hacer visibles apelando al concepto de experiencia. 
Si bien la palabra experiencia [Erfahrung] no aparece en el ensayo sobre la obra de arte, este concepto resulta fructífero para pensar las modificaciones en el mundo del arte y en la percepción que Benjamin describe allí, así como también, como veremos más adelante, para comprender la crítica benjaminiana al historicismo.

En este punto, coincidimos con la lectura de Habermas, quien afirma que "la teoría del arte de Benjamin es una teoría de la experiencia” (Habermas, 1975, p. 317). Hacer una experiencia con la obra es lo opuesto a consumirla en el más puro recogimiento e implica sumergir la obra en la vida y dejar que la transforme, como ocurre con la recepción en la dispersión propia de la arquitectura y del cine (Gandesha, 2017, p. 48). "Las tareas [die Aufgaben] que se le plantean al aparato de la percepción humana [dem menschlichen Wahrnehmungsapparat] en épocas de inflexión histórica" -dirá Benjamin- "no pueden cumplirse por la vía de la simple óptica, es decir, de la contemplación [sind auf dem Wege der bloßen Optik, also der Kontemplation, gar nicht zu lösen]” (Benjamin, 2015b, p. 65; GS I 505). Allí, el autor deja claro el tipo de relación con el arte -y, agregamos- con el mundo, que no encuentra fructífera para su presente.

Howard Caygill analiza estos dos modos de relación con la obra de arte en términos de su apertura o cerrazón. La obra aurática es cerrada:

la experiencia de una obra de ese tipo es contemplativa, y dado que los bordes de la obra de arte son inviolables, permanece igual sea cual sea la mirada a la que se encuentre sometida. Esa experiencia contrasta fuertemente con aquella de una obra de arte cuyos bordes están abiertos o son permeables, que cambia según el uso. (Caygill, 1995, p. 93)

Esa apertura es la propia de la fotografía, que para Benjamin puede "acercarse al receptor [dem Aufnehmenden entgegenzukommen]" (Benjamin, 2015b, p. 29; GS I 477) en respuesta a la demanda de las masas que quieren "acercarse las cosas [die Dinge sich 
näherzubringen]" (Benjamin, 2015b, p. 31; GS I 440) ${ }^{90}$ y, más aún, de la necesidad de "la extracción del objeto fuera de su cobertura, la demolición del aura [die Entschälung des Gegenstandes aus seiner Hülle, die Zertrümmerung der Aura]" (Benjamin, 2015b, p. 32; GS I 440).

Si bien Caygill distingue dos tipos de experiencia, no resulta tan evidente que para Benjamin pueda considerarse propiamente una "experiencia" el caso de un sujeto que se limita a contemplar. Tanto en "Sobre el programa de la filosofía venidera", uno de sus primeros escritos, como más tarde en "Experiencia y pobreza" y "El narrador", Benjamin delinea su concepto de experiencia como implicando una cierta agencia de parte del sujeto ${ }^{91}$. La diferencia fundamental del concepto de experiencia [Erfahrung] con el de vivencia [Erlebnis] es, en efecto, el carácter de elaboración que necesariamente tiene la primera. Tomando en cuenta ese rasgo de la experiencia, quizá sería posible trazar una oposición entre contemplación y experiencia como formas de vinculación con el entorno que implicarían, respectivamente, un sujeto pasivo y uno activo. Ahora bien, esto resulta problemático, puesto que el sujeto de la experiencia es, en la filosofía de Benjamin, aquel que, si bien realiza cierta elaboración de lo que vivencia, es a su vez capaz de dejar de ejercer dominio sobre las cosas -lo que implicaría mantenerlas a una distancia prudente- y permitir que éstas lo impacten. Al respecto, resultan ilustrativos tres textos breves de Benjamin. En primer lugar, un pequeño fragmento no publicado, en el que el autor da cuenta de que "el gran arte hace que las cosas se hagan más estrechas en la Tierra" (2017f, p. 283). Allí, Benjamin compara este poder del arte con el del recuerdo, que también produce "la cercanía [Nähe]" (2017f, p. 284; GS VI 203), y una forma de relación con los lugares y las cosas de la cual "el romántico distante [der distanzierte Romantiker] sabe tan poco como el positivista" (2017f, p. 284; GS VI 203).

\footnotetext{
${ }^{90}$ Esta expresión presenta diferencias en la primera y la tercera versión del escrito. En la tercera redacción se suma "espacial y humanamente" [räumlich und menschlich] (GS I 479)-

${ }^{91}$ Volveremos sobre el concepto de experiencia, indiscutiblemente central en la filosofía de Benjamin, en el próximo capítulo.
} 
En segundo lugar, resulta interesante remitir a "Hacia el planetario" [Zum Planetarium], donde Benjamin diferencia la experiencia cósmica [kosmische Erfahrung] con el universo que se desarrolla en el éxtasis y que el hombre moderno "casi no conoce" (2014, p. 122)- de la experiencia que se configura con "el florecimiento de la astrología a pricipios de la edad moderna" (2014, p. 122) y que se estructura en torno a "una conexión óptica con el universo [einer optischen Verbundenheit mit dem Weltall]" (2014, p. 122. GS IV 146). La prelación de esta conexión, para Benjamin, "implica un presagio de lo que debía venir" (2014, p. 122), que no es más que el primado de la relación meramente contemplativa -o examinadora- con el mundo: "a fin de cuentas" -dirá Benjamin sobre el tipo de experiencia que se encuentra amenazado- "el éxtasis [Rausch] es la experiencia en la que nos aseguramos lo más cercano y lo más lejano, y nunca lo uno sin lo otro [die Erfahrung, in welcher wir allein des Allernächsten und des Allerfernsten, und nie des einen ohne des andern, uns versichern]" (2014, p. 122; GS IV 146).

En tercer lugar, resulta relevante el texto "Productos chinos" [Chinawaren], incluido en Calle de mano única. Allí, Benjamin compara la relación entre leer y copiar un texto con la relación entre sobrevolar y transitar una carretera. A diferencia de la mera acción de leer o sobrevolar, que mantienen distancia respecto del objeto del que se ocupan, en los casos de copiar y de transitar por la ruta habría experiencia, pues una mayor cercanía respecto del objeto permite que el sujeto deje de tener dominio total de la situación:

Sólo el texto copiado comanda el alma de quien se ocupa de él, mientras que el mero lector nunca conoce las nuevas vistas de su ser interior, tal como las abre el texto, esa ruta que atraviesa un bosque interno que vuelve una y otra vez a cerrarse sobre ella: porque el lector obedece al movimiento de su propio yo en la zona aérea libre de la ensoñación [weil der Leser der Bewegung seines Ich im freien Luftbereich der Träumerei gehorcht], mientras que el copista deja que lo comanden. (Benjamin, 2014, p. 50; GS IV 90. Las cursivas son nuestras) 
De ese fragmento, y de las potentes imágenes que moviliza, pueden desprenderse algunas apreciaciones fructíferas para nuestro planteo, ya que una de las diferencias fundamentales de las que da cuenta Benjamin en su ensayo sobre la obra de arte es aquella entre un arte aurático, marcado por la lejanía -que es un rasgo definitorio del concepto de aura en cuanto que "aparecimiento único de una lejanía, por cercana que pueda estar" (Benjamin, 2015b, p. 31)"92-, y uno postaurático, caracterizado por la cercanía que la obra logra respecto del espectador. En "Productos chinos", por otra parte, se comparan dos situaciones donde la diferencia principal es, de nuevo, la distancia. En la experiencia de transitar la carretera o de copiar el libro hay sin duda un sujeto activo, opuesto radical del sujeto que contempla desde lejos, pero en esa actividad del sujeto hay también un dejarse comandar o impactar por el objeto. En ese sentido, en la filosofía de Benjamin también se da un reconocimiento de cierta agencialidad que nace de $\operatorname{los} \operatorname{objetos}^{93}$ y en la que conviene detenerse. En una nota al ensayo sobre la obra de arte, Benjamin plantea:

Compárese el lienzo de la pantalla sobre el que se proyecta la película con aquel sobre el que se encuentra una pintura. Sobre la una, la imagen se transforma [verändert sich]; sobre la otra, no. Esta última invita a la contemplación [Kontemplation] a quien la mira; ante ella, este puede entregarse a su deriva de asociaciones [Assoziationsablauf]. Ante una toma cinematográfica no puede hacerlo. Apenas la ha captado con el ojo, cuando ella ya se ha transformado. (Benjamin, 2015b, p. 76, n. 16; GS VII 379-380. El enfatizado es nuestro)

La oposición es clara en dos sentidos. Por un lado, con respecto a la obra: una obra se transforma, la otra no. Por el otro, y consecuentemente, con respecto al espectador: uno

\footnotetext{
${ }^{92}$ Sobre el origen de la idea de aura y la posibilidad de que el concepto en Benjamin esté inspirado en ideas de Klages, puede consultarse Echeverría (2003, p. 15) y Moretti (2013).

${ }^{93}$ Sobre la agencia de los objetos en Benjamin, un tema poco explorado y que abordaremos en mayor profundidad en la segunda sección de esta investigación, ver Ng (2011).
} 
contempla y el otro no puede hacerlo, y este cambio en la actitud no está analizado con la centralidad en la voluntad del sujeto sino haciendo hincapié en la propuesta que emana de la obra. Al reconocer la existencia de tal agencialidad que emerge de los objetos artísticos, Benjamin cuestiona el mito moderno del sujeto autoafirmado tal y como aparece en Descartes, y su "ilusión narcisista de control absoluto" (Buck-Morss, 2015, p. 165) ${ }^{94}$. Esto ocurre también respecto de los sueños y los recuerdos, que en la filosofía de Benjamin se consideran capaces de aparecer e irrumpir, por lo que exigen una elaboración por parte del sujeto. Algo similar sucede en el ámbito de la historia, como veremos en el siguiente apartado.

Al cuestionar desde lo más profundo la concepción del hombre y de su relación con el mundo, para desmontar así los mitos que implica, la teoría benjaminiana de la experiencia es capaz de adquirir una potencialidad política que está ausente en otras concepciones de la experiencia. Al respecto, es interesante el punto de vista de Habermas, quien, si bien interpreta el llamado a politizar el arte como no estando imbricado con la batería de conceptos de Benjamin, da a su vez algunas indicaciones para interpretar lo contrario. En sus palabras,

la politización del arte es un concepto que Benjamin se encontró ahí. Pudo tener muy buenas razones para hacerlo suyo, pero no guarda ninguna relación sistemática con su propia teoría del arte y de la historia. Al adoptarlo tan sin reservas Benjamin está confesando tácitamente que de su propia teoría de la experiencia no es posible obtener una relación inmanente con la praxis política. (Habermas, 1975, p. 327)

Si bien no estamos de acuerdo con la tesis principal que Habermas esboza aquí, creemos que es importante destacar algunos de los lazos que establece. En primer lugar, entre la teoría de la experiencia y el concepto de politización -y con él, podemos pensar, como su opuesto, el

\footnotetext{
${ }^{94}$ Asimismo, y como sostiene Abadi (2015) la politización del arte en Benajmin "arranca a la imagen de la distancia contemplativa y la fusiona con el cuerpo y con la acción (...) El "espacio de la imagen" debe funcionar como "inervación" del cuerpo colectivo: de los estímulos de este tejido nervioso provendría la acción política" (p. $65)$.
} 
de estetización-. En segundo lugar, entre el concepto de politización y las teorías del arte y de la historia.

De acuerdo con nuestra interpretación, el llamado a politizar el arte es una conclusión que se desprende de repensar los cambios en los modos de producción, circulación y recepción de las obras de arte como parte de cambios mayores en la estructura y en las posibilidades mismas de la experiencia en el siglo XX. En efecto, y recuperando la interpretación de Koepnick,

al conceptualizar la estetización fascista principalmente como una orquestación políticamente efectiva de la percepción sensorial, en lugar de simplemente verla como la gestión escénica de la política, Benjamin sitúa su crítica del fascismo en el contexto de una historia materialista de la experiencia individual y colectiva. (Koepnick, 1999, p. 12)

Y si bien es cierto que la teoría de la experiencia de Benjamin no permite deducir un programa político, no lo es menos que es una herramienta productiva para pensar algunas prácticas que rigen la vida contemporánea y para indicar algunas tareas, como lo hace Benjamin: la politización del arte, lejos de estar desconectada de esta teoría, es una de ellas y la politización de la historia podría ser otra, como veremos a continuación.

\subsection{Estetización del pasado o politización de la historia}

Mira al pasado sin nostalgia, casi con intriga: para ella es un paisaje que debe contemplarse fríamente.

María Gainza, 2017, p. 227

Nos enfocaremos ahora en el ámbito de las reflexiones sobre la historia, donde aparece la crítica a "la contemplación [Beschaulichkeit], tan característica del historicismo" (Benjamin, 
2009c p. 71; GS II 468) o a aquello que denominaremos, tomando la expresión de Elizabeth Collingwood-Selby, una "relación contemplativa y estetizante con el pasado" (2012, p. 131).

Como es sabido - en tanto se trata, en efecto, de uno de los puntos más revisados de su pensamiento- Benjamin realiza una crítica radical al historicismo ${ }^{95}$, el cual propone, respecto de la relación con el pasado, "la supresión, la suspensión, de toda inclinación biográfica singular, de toda experiencia, de toda pasión, de toda creencia presente que pueda distorsionar la verdad objetiva y siempre igual a sí misma del acontecimiento histórico" (CollingwoodSelby, 2012, p. 94). En su concepción del conocimiento histórico, el historicismo da muestras de varios tópicos epistemológicos de los que Benjamin quiere alejarse. Como señala Manuel Reyes Mate (2009, p. 19), las Tesis benjaminianas "Sobre el concepto de historia" están vertebradas tanto por una propuesta epistemológica como por una de orden político que incorpora en su centro algunos postulados del mesianismo judío. Para los fines de este capítulo, nos interesa indagar en algunos aspectos de la epistemología que Benjamin esboza en sus escritos sobre historia, ya que allí ofrece algunas críticas a la matriz moderna de la representación y al dualismo entre sujeto y objeto que resultan relevantes para abordar la problemática de la estetización, como ha notado Naishtat (2008).

Benjamin caracteriza el enfoque historicista a raíz de la tríada que componen sus concepciones de la historia, del pasado y del tiempo, como partes de una misma “ideología del progreso"96, ante la cual sucumben no sólo las posturas conservadoras, sino también algunas versiones del marxismo. Puesto que el historicismo parte de entender la historia como la ciencia que representa el pasado "como verdaderamente ha sido [wie es denn eigentlich gewesen ist]" (Benjamin, 2009, p. 113; GS I 695), deja entrever su concepción del pasado como algo acabado,

\footnotetext{
95 Acerca de a qué se refiere Benjamin con "historicismo", recomendamos consultar Kittsteiner (1986). Allí, la autora repone la información que Benjamin omite en sus por momentos crípticas tesis, analizando para ello no sólo este escrito sino también la Obra de los pasajes.

${ }^{96}$ Vargas da cuenta de que, para Benjamin, y mientras que en el siglo XIX tenía potencialidad crítica, "en el siglo XX el concepto de progreso encubría regresiones económicas, políticas y sociales” (2018, p. 39).
} 
algo que ha sido de una determinada manera y que se puede observar analíticamente desde el presente, pero cuya modificación resulta imposible. Ese pasado es aquel del que hay documentos y monumentos, esto es, el pasado memorable o, como dice Benjamin, el pasado de la tradición de los vencedores; y lo es en tal medida que no resulta necesario formular "la pregunta de con quién entra en empatía el historiador historicista. La respuesta es que, innegablemente, con el vencedor" (Benjamin, 2009, p. 129).

En efecto, la historia tal y como la conocemos encadena en un sentido causal los momentos memorables de la historia de los vencedores, con lo cual traza una continuidad ininterrumpida de sucesos que conforman cierta tradición. Collingwood-Selby pone el foco de atención en esta empatía medular del historicismo con los vencedores y en el carácter problemático de incorporar la empatía al proceso de rememoración, en la medida en que el historiador, desde su posición que considera neutral, "se ve inevitablemente determinado por aquello que, habiendo vencido, se impone en el presente como la matriz naturalizada e invisible" (Collingwood-Selby, 2012, p. 30) que estructura el modo en que se considera el pasado. Quienes emplean la empatía como procedimiento se suponen capaces de revivir una época pasada y poner entre paréntesis el transcurso ulterior de la historia en lugar de elaborarlo críticamente, pero con ello no hacen más que dejar que aquello que ha vencido, esto es, "las categorías y los mecanismos de percepción, de interpretación y de clasificación que, inadvertidos ellos mismos, determinan y organizan epocalmente el régimen general de la representación, del conocimiento y de la tipificación de lo histórico" (Collingwood-Selby, 2012, p. 31), determine la visión y la valoración del presente sobre el pasado, al aportar las categorías con las que se aborda.

Una idea que se corresponde con esta manera de comprender la historia como cadena de causas y efectos observables es la idea de que la humanidad progresa o avanza en ella. Como 
menciona Reyes Mate (2009, p. 14), esta lógica del progreso, que compartían comunistas y fascistas, era lo que sobre todo debía ser desarticulado. Benjamin lo deja claro en la Tesis VIII:

No tiene nada de filosófico asombrarse de que las cosas que estamos viviendo sean "todavía" posibles en pleno siglo XX. Es un asombro que no nace de un conocimiento [Es steht nicht am Anfang einer Erkenntnis], conocimiento que de serlo tendría que ser éste: la idea de historia [die Vorstellung von Geschichte] que provoca ese asombro no se sostiene. (Benjamin, 2009, p. 143; GS I 697)

Benjamin "asume el riesgo de disputar a los conservadores la crítica al progreso" (Reyes Mate, 2009, p. 162) y equipara el progreso con la catástrofe, de manera que "la catástrofe misma, en cuanto tal, es el que esto 'se siga produciendo' [Daß es 'so weiter' geht, ist die Katastrophe]" (Benjamin, 2013, p. 762; GS V 592). El concepto de progreso, como afirma en la Tesis XIII, "no se atenía a la realidad, sino que tenía una pretensión dogmática [dogmatischen Anspruch]" (Benjamin, 2009, p. 211; GS I 700), ya que se trataba del progreso de la humanidad misma, inacabable e imparable. Benjamin considera la idea de que la humanidad en su conjunto progresa en la historia como algo absolutamente insostenible a la luz de los acontecimientos que marcan el siglo XX, pero también como una idea peligrosa en el ámbito político, pues, al poner la mirada fija en el futuro ${ }^{97}$, no presta atención al cúmulo de ruinas y de muertos que el "progreso" amontona. Nuestro autor trata así de desactivar el mito del progreso para echar luz sobre todo aquello que esa matriz de pensamiento no logra explicar.

Por último, hay que mencionar algo primordial por su importancia y por los efectos que produce: el historicismo se caracteriza en función de su concepción del tiempo como algo homogéneo y vacío, como un telón de fondo donde se posan los acontecimientos que en línea recta se transforman de futuro o proyecto en presente y de presente en pasado, para luego

\footnotetext{
${ }^{97}$ Como detallaremos en el capítulo 5 en torno a la noción de experiencia, el desentendimiento respecto del pasado y la ilusión plasmada en el porvenir que se augura floreciente es un rasgo que la burguesía compartirá, para Benjamin, con los adictos a los juegos de azar.
} 
quedar sepultados por el tiempo y perder su relevancia. En la Tesis XIII se expone esta complicidad de la ideología del progreso con cierta concepción del tiempo:

La idea de un progreso del género humano en la historia es inseparable de la idea según la cual la historia procede recorriendo un tiempo homogéneo y vacío [eine homogene und leere Zeit]. La crítica a la idea de un tal proceso tiene que constituir la base de la crítica a la idea de progreso. (Benjamin, 2009, p. 211; GS I 701)

Así, Benjamin no ataca sólo una de las tesis del historicismo, sino todo su andamiaje teórico y, al poner el foco de atención en su concepción de la historia, del pasado y del tiempo, cuestiona sus supuestos epistemológicos básicos y la funcionalidad política que se desprende de su necesaria empatía con los vencedores.

A partir de esta crítica, Benjamin planteará como contrapropuesta otro modo de comprender la tarea de la historia, el pasado y el tiempo. En primer lugar, la historia ya no será el acopio de los logros de la humanidad y su encadenamiento causal, porque en su filosofía el conocimiento no estará ligado a la representación de lo dado.

La diferencia radical entre ambos enfoques se expresa con toda claridad en esta afirmación: “el historicismo postula una imagen 'eterna' del pasado [das 'ewige' Bild der Vergangenheit]; el materialismo histórico, en cambio, una experiencia [Erfahrung] con ese pasado, que es única” (Benjamin, 2009, p. 249; GS I 702). Al respecto, cabe recordar el carácter práctico de la experiencia en la filosofía de Benjamin al ser una elaboración, como explicamos en el apartado anterior: la tarea de hacer una experiencia con el pasado implica emprender un trabajo sobre lo heredado, una crítica de la tradición, un rescate de lo no representado en la historia y una actualización de las luchas políticas frustradas. Tal y como aparece en la filosofía de Benjamin -y como especificaremos en el próximo capítulo- la experiencia en sentido estricto es "una forma socioindividual de apropiación, en la cual la relación consigo mismo y la relación con el mundo están articuladas entre sí, y transforma por igual a lo apropiado y al 
apropiador" (Weber, 2014, p. 505). Hacer una experiencia con el pasado es, al mismo tiempo y como siempre que se trata de hacer una experiencia tal y como Benjamin la entiende, emprender un trabajo de destrucción o desarticulación y uno de construcción, pues en efecto, "la historia es objeto de una construcción [die Geschichte ist Gegenstand einer Konstruktion]" (Benjamin, 2009, p. 223; GS I 701).

En este punto resulta interesante remitir a una de las Denkbilder de Calle de mano única, titulada “Obra en construcción” [Baustelle] (Benjamin, 2014, pp. 53-54; GS IV 92-93). Allí Benjamin se refiere al juego infantil como una construcción o un montaje armado a partir de desechos o ruinas, de manera que lo distingue de cualquier forma de creación a partir de la nada, pero también de la mera utilización apropiada de objetos diseñados con un papel específico. Los niños, según Benjamin, construyen su pequeño mundo de objetos a partir de los materiales que encuentran en el mundo y, como el historiador materialista, no se limitan a quedarse boquiabiertos ante los objetos en una relación contemplativa con ellos, sino que elaboran esa relación mediante la construcción.

Del mismo modo, la experiencia con el pasado implica entablar una relación con él que no se limite al plano cognoscitivo. Al respecto, resulta crucial el debate epistolar con Horkheimer de 1937, en el marco del cual Benjamin explica que:

La historia no es sólo una ciencia sino también y no menos una forma de recordación [Eingedenken]. La recordación puede modificar lo que la ciencia da por definitivamente establecido. La recordación puede convertir lo no clausurado (la felicidad) en algo clausurado y lo clausurado (el sufrimiento) en algo no clausurado. Eso es teología. Ahora bien, en la recordación hacemos una experiencia que nos prohíbe comprender la historia de una manera fundamentalmente ateológica, de la misma manera que no nos es permitido escribirla con conceptos estrictamente teológicos. (Benjamin, 2009, p. 75) 
Si bien analizar la relación de Benjamin con la teología excede los límites y los objetivos de nuestra investigación ${ }^{98}$, nos interesa retomar de ese debate el papel de la rememoración en la consideración de la historia y el modo en que Benjamin se desplaza de la comprensión tradicional de la historia para incluir en ella a la experiencia y, en particular, a la experiencia singular que proporciona "la memoria de las injusticias pasadas" (Reyes Mate, 2009, p. 74), la cual "no nos permite cerrar los oídos a los gritos de las víctimas que claman por su derechos" (Reyes Mate, 2009, p. 74).

En el marco de esta nueva forma de comprender la historia como una actividad eminentemente política, "el historiador conoce [...] en tanto en cuanto ha hecho la experiencia de la lucha y de la opresión” dice Reyes Mate 2009 (p. 201) y agrega, en discusión con Gerhard Kaiser, que "no se trata de conciencia (que remite a conocimiento teórico) sino de experiencia (que es de entrada conocimiento práctico)" (Reyes Mate, 2009, p. 201, n. 3. Las cursivas son nuestras). Y es que, como sostiene Habermas, "Benjamin concibió (...) la filosofía de la historia como teoría de la experiencia” (Habermas, 1975, p. 312) o al menos relacionó estrechamente la primera con la segunda, al preguntarse por los modos en que nos relacionamos con el pasado y en que el pasado se presenta en el presente.

Hansen, por su parte, también observa esta relación entre experiencia y memoria desde el prisma de la crisis de la experiencia, en el que nos centraremos en el próximo capítulo. Y es que

el declive de la experiencia, Erfahrung en el sentido enfático que le da Benjamin, es inseparable del de la memoria, la facultad que conecta las percepciones sensoriales del presente con las del pasado y que, por lo tanto, nos permite recordar tanto los sufrimientos pasados como los futuros olvidados. (Hansen, 2012, p. 81)

\footnotetext{
${ }^{98}$ Para una reconstrucción y una interpretación en torno a dicho debate y sobre el papel de la teología en la filosofía de Benjamin, cfr. Reyes Mate (2009, pp. 73-75) y Naishtat (2016).
} 
Así, la relación con el pasado en Benjamin no es contemplativa ni implica una mirada neutral, sino que se da en forma de acción y, específicamente, de acción política, en la medida en que supone la recuperación de las luchas de los vencidos de la historia y su actualización, en cuanto que "el historiador materialista no hace historia por erudición, sino con el fin práctico de cambiar las cosas" (Reyes Mate, 2009, p. 255).

La propuesta consiste en responder a la estetización del pasado y a la relación meramente contemplativa con los sucesos históricos, concebidos como hechos acabados y cerrados. Koepnick, crítico de esta forma de comprender los acontecimientos históricos -aún vigente- $-{ }^{99}$, sostiene, en el marco de su crítica a Goldhagen ${ }^{100}$ :

Dado que Goldhagen les aseguró que el presente y el pasado no tienen relación entre sí, los lectores alemanes podrían reconocer el período nazi como un depósito del mal absoluto, pero también de una distancia absoluta. Viajar al pasado de esta manera resultó no ser muy diferente de viajar a una isla remota, un parque temático de maravillas espeluznantes. Los verdugos alemanes complacientes de Goldhagen y los monstruos jurásicos de Spielberg acaban siendo como criaturas de la misma era. (Koepnick, 1999, p. 11. Las cursivas son nuestras)

Para Benjamin, contrariamente, la historia no será un viaje al pasado que nos muestre escenarios fijos que den cuenta del estado del mundo en tiempos y lugares remotos. Muy por el contrario,

la historia, para Benjamin, no es ni la historia del pensamiento ni la historia de los líderes políticos, sino la historia de la experiencia, una historia que trae al primer

\footnotetext{
${ }^{99}$ Por ejemplo, fue la postura de Martin Broszat, historiador que supo estar afiliado al partido Nazi (lo que ocultó dirante su vida y se supo en 2003, tras su muerte) y ha sostenido que el período del nacionalsocialismo debería estudiarse en Alemania con la distancia propia de un acontecimento que ya no guarda una relación relevante con el presente. Al respecto puede consultarse Frei (2007).

${ }^{100}$ Daniel Jonah Goldhagen es un escritor estadounidense y ex profesor asociado de ciencias políticas y sociología de la Universidad de Harvard. Goldhagen fue conocido internacionalmente por haber escrito dos libros controvertidos sobre el Holocausto: Los verdugos voluntarios de Hitler (1996) y La Iglesia católica y el Holocausto (2002). También ha escrito Peor que la guerra, un libro de 2009 que examina el fenómeno del genocidio.
} 
plano las formas contingentes en las que nos apropiamos del material cultural dentro del entramado de la vida cotidiana para construir identidades y tomar posición en tiempo y espacio (Koepnick, 1999, p. 12).

De lo que se trata, como sostenemos, es de un proyecto que se opone a cualquier caracterización museificada del pasado. Y en esta tarea, creemos, es posible encontrar una fuerte afinidad con el llamado a politizar el arte, ya que "el interés histórico, al que le concierne lo pasado — pero, en este y a través de este, el presente más actual— resulta ser un interés político" (Weidmann, 2014, p. 310). A fin de cuentas, de lo que se trata es de politizar la historia o, como dirá el mismo Benjamin, de "cambiar la mirada histórica al pasado por otra política [der Auswechslung des historischen Blicks aufs Gewesene gegen den politischen]" (Benjamin, 2007b, p. 306; GS II 300).

De nuevo, estetización y experiencia se oponen como modos radicalmente distintos de relación con el mundo y se presentan como relaciones entre términos que son también diferentes. En el historicismo, el objeto histórico son los hechos pasados plasmados en documentos y el sujeto que hace historia es el investigador que repasa esos hechos. En la propuesta benjaminiana la clave está en dejar de entender el pasado como algo concluido y abrazar la posibilidad de su apertura: el pasado tiene aún vigencia y actualidad, los muertos están en cierto sentido entre nosotros en tal medida que "ni siquiera los muertos estarán seguros si el enemigo vence" (Benjamin, 2009, p. 113). Asimismo, el pasado con el que se entabla la relación no es el de la tradición de los vencedores, de la que sobran monumentos y documentos, sino el de la tradición de los vencidos, de la que sólo hay ruinas.

Como en el arte, el objeto que en otras consideraciones aparece pasivo y cerrado tiene un doble movimiento. Por un lado, abre sus límites; por el otro, se convierte en agente. En las Tesis de Benjamin, el pasado no está emplazado en un compartimento específico de la ciencia en forma de hechos y documentos, sino que irrumpe, aparece, se presenta, exige y reclama: 
¿Y el objeto? No es algo que esté ahí, inerte, sino algo que "sale al encuentro como una mónada", es decir, es un momento del pasado que se desprende de su contexto, que sale de la órbita en el que lo ha colocado la lógica de la historia, que se planta, que desafía a la lógica histórica del progreso y también al sujeto que quiera conocerlo porque no se va a dejar tratar como un objeto pasivo. (Reyes Mate, 2009, p. 268)

Benjamin plantea la agencialidad del pasado, su papel activo y su resistencia a ser reducido a un mero objeto de conocimiento en la Tesis VI, donde la imagen del pasado "se presenta sin avisar al sujeto histórico en el instante de peligro [Augenblick der Gefahr]" (Benjamin, 2009, p. 113; GS I 695) ${ }^{101}$. Así lo entiende también Galende: para el autor, la iluminación profana tiene que ver, no con un método, sino con la treta [Trick] (GS II 300) a la que refiere Benjamin en el texto sobre el surrealismo ${ }^{102}$, que consistiría en ese corrimiento de la mirada al pasado. Galende recupera esta idea y sostiene:

La treta que Benjamin menciona consiste en un desplazamiento "político" de la mirada histórica del historicismo. Este desplazamiento no alude a lo político como una estrategia reconstructiva, alude a lo político como una disrupción. La treta política es así a la mirada histórica del historicismo, lo mismo que la destrucción a la reconstrucción historiográfica del pasado. En este caso, la destrucción es concebida como la inesperada irrupción del objeto anacrónico que, liberándose a sí mismo del curso temporal, libera también al propio instante de percepción de la coraza que a las huellas mnémicas le impone el sistema-consciencia. (Galende, 2009, p. 196)

\footnotetext{
${ }^{101}$ En este fragmento, pero no sólo en él, se constata la influencia de Marcel Proust en la obra de Benjamin. Específicamente, la manera de abordar el pasado y la memoria involuntaria a lo largo de En busca del tiempo perdido resulta un antecedente claro de la crítica benjaminiana a la concepción lineal del tiempo, cfr. Melamed (2012) y Weber (2014).

102 Sobre la importancia del surrealismo en el pensamiento de Benjamin puede consultarse Ibarlucía (2020).
} 
Como el historiador materialista entiende radicalmente que el pasado tiene esa potencia disruptiva, no se contentará con inventariar hechos, pues "la inventarización es una forma de la trasmisión que 'impermeabiliza' el contenido de lo transmitido respecto de la experiencia de los hombres" (Weber, 2014, p. 517), sino que deberá asumir la tarea de redimir ese pasado y actualizar las luchas que han fracasado en él, ya que "necesitamos historia, pero la necesitamos de una manera distinta a como la necesita el holgazán malcriado en el jardín del saber [der verwöhnte Müßiggänger im Garten des Wissens]" (Nietzsche, en Benjamin, 2009, p. 197; GS I 700).

En este contexto, los intentos por inventariar los hechos pasados aparecen como formas de quitarle al pasado poder sobre el presente en la medida en que lo convierten en objeto de contemplación. A su vez, el sujeto mantiene la ilusión de tener el control sobre esos hechos pasados al inventariarlos y opera con ellos, dominándolos y disponíéndolos. Así, esta operación resulta un intento por despolitizar la relación con el pasado. La escritura historiográfica de Benjamin, por el contrario, y como sostiene Naishtat,

asume (...) la forma de una prosa performativamente afín a la dislocación de la temporalidad lineal, y que presupone otros dispositivos de composición, vinculados a la capacidad de muestra del discurso, en una performatividad política característica de ciertas figuras benjaminianas como la constelación saturada, la alegoría y la imagen dialéctica. (2008, p. 3)

Como apunta Weidmann, el giro copernicano que Benjamin imprime al pensamiento histórico implica pensar "un presente que es restablecido por completo a través del pasado" (Weidmann, 2014, p. 308), para dejar de considerar el pasado y el presente como dos esferas separadas entre sí por completo y para no caer tampoco en la consideración progresiva del tiempo, que los liga como puntos sucesivos de una línea temporal (Kuffer, 2015). El pasado se comprende de un modo nuevo, pero también el sujeto que hace la experiencia con el pasado 
está lejos de ser el sujeto que la tradición de la Modernidad le legó a la filosofía. En primer lugar, el sujeto de la historia, aun cuando es difícil de establecer, es colectivo. En la Tesis XII Benjamin dice que "el sujeto del conocimiento histórico es, por supuesto, la clase oprimida que lucha [das Subjekt historischer Erkenntnis ist die kämpfende, unterdrückte Klasse selsbt]" (Benjamin, 2009, p. 197; GS I 700). Al respecto, Reyes Mate sostiene que Benjamin no está pensando en el proletariado de la lucha de clases, aquel que tenía en Marx el poder de cambiar la historia, sino en un sujeto que se caracteriza por su debilidad y por ser parte de la tradición de los vencidos. "Cuando él piensa en un sujeto capaz de comprender lo que debe ser comprendido" - continúa Reyes Mate- "no está pensando en ese ser moderno que ha llegado a la edad adulta al hacer un uso público, crítico y autocrítico de la razón” (Reyes Mate, 2009, p. 20), sino que está tratando de indagar en el potencial de la capacidad cognitiva del sujeto que sufre, esto es, priorizando la experiencia ante el conocimiento. Así, se plantea un saber del oprimido, que nace de la conciencia de que para él el estado de excepción es la norma, como se sostiene en la Tesis VIII.

Asimismo, tal sujeto es activo, pues "hace historia no para prorrogar la existente, sino con la intención de introducir nuevos elementos que interrumpan el curso fatal de los acontecimientos" (Reyes Mate, 2009, p. 240). Aun así, como en el caso del arte, no se trata del sujeto moderno que domina el mundo, que ordena y narra el pasado colocándose como punto de llegada en la carrera teleológica hacia la perfección, sino de un sujeto abierto a la escucha y permeable, con "una débil fuerza mesiánica [eine schwache messianische Kraft] sobre la que el pasado tiene derechos" (Benjamin, 2009, p. 67; GS I 694).

Por último, esa relación entre el pasado y el presente, o entre lo que ha sido y el ahora, sólo se puede pensar si dejamos de entender el tiempo como una mera sucesión de momentos. El tiempo que es necesario para hacer historia en un sentido benjaminiano es un tiempo cualitativo, un tiempo repleto de ahora -tiempo-ahora o Jetztzeit-. En ese sentido, el tiempo- 
ahora no se limita al presente, sino que es una característica que puede tener un hecho del pasado: se trata de la actualidad. Ir hacia ese pasado cargado de ahora es justamente lo que corresponde a la acción revolucionaria.

Lo interesante de la posición benjaminiana es que recupera el pasado como instancia significativa, en contra de la actitud moderna de dejarlo atrás como algo que ya no es y ya no sirve -a la que volveremos en el capítulo 5-, pero lo logra sin caer en una posición conservadora: su mirada al pasado no quiere volver a un estadio anterior ni afirma que todo tiempo pasado fue mejor. Benjamin no centra su atención en los triunfos de ese pasado, sino en sus fracasos y en sus víctimas, para actualizar sus luchas y generar una situación que les haga justicia en el tiempo presente: en contra de "esta historia monumental, Benjamin rastrea las capas ocultas tras la aureola gloriosa y el brillo de la historia consagrada" (Naishtat, 2008, p. 15). En ese sentido, Benjamin presenta un "materialismo histórico que en sí justamente ha aniquilado por completo la idea de progreso [der die Idee des Fortschritts in sich annihiliert hat]" (Benjamin, 2013, p. 739; GS V 575) y, en este marco, propone como operación opuesta a la idea de progreso la actualización. Mientras que el progreso deja víctimas a su paso y avanza victorioso, mirando siempre hacia adelante, en dirección al futuro, la actualización alude a un movimiento contrario, que consiste en mirar hacia atrás y volver a la vida aquello que agoniza, que no es nunca nada parecido a un hecho histórico ni mucho menos a un bien cultural, sino siempre algo vivo, una lucha, una víctima, o bien alguna de esas cosas "finas y espirituales [feinen und spirituellen]" a las que se refiere Benjamin en la Tesis IV (Benjamin, 2009, p. 95; GS I 694). A su vez, y en tanto "la creencia en el progreso conducía (...) a una crisis de la praxis política" (Vargas, 2018, p. 40), la desconfianza en este avance nos activa, aun cuando nos mueva hacia la detención, como queda claro en la metáfora de la locomotora que emplea Benjamin al indicar la tarea de activar los frenos de emergencia. 
De la misma manera en que el pasado no es ese hecho clausurado por conocer, sino que "se mueve (...) y no está petrificado" (Naishtat, 2008, p. 23), así el presente no es ese mero tiempo de tránsito que se escurre como arena entre nuestros dedos, sino un tiempo denso: el potencial revolucionario del ahora surge del hecho de que no se limita a ser un estado dado de cosas, sino que es "el momento de constante posibilidad revolucionaria" (Buck-Morss, 2005, p. 24). Este cambio de paradigma es esencial para la filosofía de la historia que Benjamin propone: el cambio, la revolución y, en fin, la justicia y la felicidad no se encuentran en un futuro más o menos lejano, sino que son posibilidades del presente, en la medida en que este sea un tiempo creativo en su relación con el pasado.

\subsection{Consideraciones finales: estetización o experiencia}

No contemplación, sino política; no fascinación, sino interpelación.

Manuel Reyes Mate, 2009, p. 160

Como hemos mostrado a lo largo del capítulo, es posible encontrar en la filosofía de Benjamin interesantes continuidades entre las reflexiones sobre el arte y aquellas sobre la historia. En especial, hemos rastreado como un posible vaso comunicante la tematización del problema de la estetización, que se presenta en la forma de una crítica explícita a la estetización de la política en manos del fascismo, más explorada, pero también como un cuestionamiento a la relación estetizante con el pasado que propone el historicismo.

En efecto, como supo señalar también Fürnkäs (2014), existe una continuidad entre el ensayo sobre la obra de arte y el escrito sobre la historia, que son quizá los dos textos más estudiados y citados de Benjamin. Ambos textos poseen, como tantos otros escritos del autor, un aspecto destructivo -liquidar el aura, interrumpir la historia-, pero también un aspecto constructivo que indica una tarea u orienta una acción: la politización del arte o la actualización 
de las luchas de los antepasados oprimidos como politización de la historia (Andersson, 2014, p. 363; Galende, 2009).

En la lectura que proponemos, el extremo de aquello que Benjamin intenta desarticular se acerca a la contemplación pasiva de un objeto que se presenta como algo acabado, sea la obra de arte protegida por el aura que irradia y en la que se envuelve, sea el acontecimiento histórico concebido como algo clausurado y sin posibilidad de verse modificado, impermeabilizado por el modo de su trasmisión. En ambos casos, la contrapropuesta benjaminiana implica entablar una relación a todas luces activa con el pasado y con el mundo: un pasado y un mundo que se caracterizan, en su filosofía, por no ser nunca hechos consumados y fijos que el hombre meramente contempla o conoce. Tras la redefinición de la experiencia, a la que volveremos más adelante, este concepto desempeña un papel clave como posible articulador de la relación del hombre con el arte y con el pasado en un sentido opuesto al de la estetización y cargado de potencialidad política.

En torno a esta relación entre estetización y experiencia, Koepnick, cuya interpretación compartimos, ha sostenido que "la piedra angular de la tesis sobre la estetización" (Koepnick, 1999, p. 12) es ni más ni menos que "la teoría benjaminiana de la experiencia histórica y la percepción sensorial" (Koepnick, 1999, p. 12), esto es, coloca en el centro mismo de la teoría de la estetización los dos problemas que abordamos aquí y que tienen por eje la experiencia: la experiencia del pasado y los cambios en la percepción que, en el ámbito del arte y más allá de él, conmocionan nuestra manera de experimentar el mundo.

En ese sentido, resulta importante recordar que "el pensamiento filosófico de Benjamin está centrado en una teoría de la experiencia, sobre la cual se ha llamado la atención ya tempranamente como ‘el centro de ningún modo oculto’ de todas sus preocupaciones” (Steiner, 2014, p. 243), en la medida en que el concepto de experiencia es "un concepto articulatorio" (Weber, 2014, p. 489) que implica siempre la modificación de la realidad y no sólo su 
descripción. En la historia y en el arte, Benjamin rechaza de plano la relación contemplativa que deja que las cosas sean lo que siempre han sido y las conserva en el marco de una tradición cerrada y continua. Esto queda claro en "El carácter destructivo", cuando Benjamin critica a aquellos que "transmiten las cosas en tanto que las hacen intocables y las conservan [überliefern die Dinge, indem sie sie unantastbar machen und konservieren]" (Benjamin, 1989b, p. 160; GS IV 398).

En ese sentido, cuando Benjamin se pregunta, en "Experiencia y pobreza”, “¿qué valor tiene toda la cultura si la experiencia no nos conecta con ella? [Denn was ist das ganze Bildungsgut wert, wenn uns nicht eben Erfahrung mit ihm verbindet?]" (Benjamin, 2007a, p. 218; GS II 215), se opone rotundamente a la inventarización de la cultura y a la estetización de los bienes culturales y de la historia, para buscar en ambos ámbitos por igual "una experiencia auténtica, esto es, política [echte, d. i. politische Erfahrung]” (Benjamin, 2009c, p. 81. Traducción levemente modificada; GS II 477). Al respecto, compartimos la observación de Kang en el sentido de que, para Benjamin, lo político se refiere no tanto a cuestiones ideológicas o institucionales, sino más bien a los modos de organizar la experiencia (Kang, 2014, p. 130).

Para concluir, nos interesa destacar la importancia que adquiere en esta articulación modificar la concepción del sujeto y del objeto que toman parte en la relación no estetizante que no se configuran, estrictamente, como sujeto y objeto-. En la filosofía de Benjamin, la relación del hombre con el mundo aparece modificada en su estructura misma. Como mencionamos algunos párrafos antes, el sujeto de la experiencia es aquel que se deja comandar -como el copista en "Productos chinos"-, que se deja impactar por el cine o por los shocks de la ciudad -como Baudelaire o como las masas que tienen una recepción de la obra en la disipación-, que recuerda y escucha sus sueños - como el mismo Benjamin tenía costumbre de hacer-, que permite que el pasado vuelva y acude a la cita con él -como el historiador 
materialista en las Tesis, como el héroe en la novela proustiana-. Alejado de aquel poderoso sujeto que se constituye en el cogito y que luego sale al encuentro de un mundo que controla, mide, conoce y del que se apropia, pero también alejado de un sujeto pasivo que meramente observa o consume, el sujeto que delinea Benjamin tiene la tarea de hacer un trabajo con todo aquello que no es él mismo -la obra de arte, el pasado, el mundo- pero que lo constituye de forma radical. Es en ese sentido que el concepto de experiencia cumple una tarea articulatoria: entre el individuo y el colectivo, entre el sujeto y el objeto, entre la actividad y la pasividad, entre la cercanía y la distancia.

En la historia y en el arte, la tarea a la que invita el autor implica entablar una relación con la obra de arte o con el pasado que deja de concebirlos como "objetos frente a sí" [sich gegenüber] (Benjamin, 2007d, p. 166; GS II 161). A su vez, la contemplación de objetos externos deja de resultar adecuada en tanto las cosas se han acercado. Al respecto, resulta relevante recordar el texto "Espacios en alquiler" [Diese Flächen sind zu vermieten], de Calle de mano única, donde Benjamin postula que ya ha pasado la hora de la crítica, ya que:

La crítica es una cuestión de adecuada distancia [Kritik ist eine Sache des rechten Abstands]. Está en casa en un mundo donde lo que importa son las perspectivas y las proyecciones, y donde aún era posible asumir un punto de vista. Entretanto, las cosas han arremetido con demasiada fuerza contra la sociedad humana [Die Dinge sind indessen viel zu brennend der menschlichen Gesellschaft auf den Leib gerückt]. La imparcialidad, la mirada independiente, se han vuelto mentira, cuando no expresión completamente ingenua de llana incompetencia. (Benjamin, 2014, p. 103; GS IV 131. El enfatizado es nuestro) ${ }^{103}$

Este diagnóstico es aplicable tanto al ámbito artístico -y, en general, al de la sensibilidad- como al de la historia. En ambos casos el objeto aparece como algo abierto,

\footnotetext{
${ }^{103}$ A su vez, aquí Benjamin reniega, como veremos en el capítulo 7, de todos los intentos de estetización del mundo, como conceptualización del mismo que lo postula como algo acabado y externo al sujeto, que puede observarse cabalmente.
} 
cercano y agente. Abierto, pues sus bordes son borrosos: la obra de arte sale del marco que le imponía el aura y se convierte en un proyectil; el pasado no está ya concluido. Cercano, en la medida en que se cancela la distancia que lo separa del sujeto. La obra de arte se acerca al receptor gracias a su carácter de reproducible, al tiempo que abandona su emplazamiento; el pasado se acerca en la medida en que los muertos están aún entre nosotros. Por último, el objeto es agente ${ }^{104}$ en la medida en que deja de estar a disposición del sujeto y condiciona la relación que éste puede entablar con él; cuando la obra sale y choca, el espectador debe responder y elaborar una vivencia de shock; cuando el pasado emerge, se impone y exige, es una tarea del presente acudir a su encuentro.

\footnotetext{
${ }^{104} \mathrm{Si}$ bien en este punto las ideas de Benjamin se acercan a-o pueden comprenderse como antecedentes relevantes de- algunos postulados de Bruno Latour, este autor no solo no estaría de acuerdo con esta afirmación, sino que ha escrito incluso un artículo criticando muy duramente el ensayo sobre la obra de arte. Allí, junto a Antoine Hennion (Hennion y Latour, 2003), critica el concepto de aura por ambivalente, califica las reflexiones benjaminianas sobre la técnica como incorrectas y valora el texto en su totalidad como equivocado y reduccionista. Finalmente, y quizá sin notarlo, los autores otorgan de todos modos un reconocimiento a Benjamin, al sostener que es necesario un nuevo tipo de análisis de la obra de arte en la época de su reproductibilidad técnica, y valorar así aquel objeto de estudio que es, sin dudas, parte de su legado.
} 
Segunda sección

La crisis de la experiencia en la filosofía de Walter Benjamin: diagnósticos y redefiniciones 


\title{
Introducción
}

\author{
El dolor es constitutivo de la experiencia. Una vida que consistiera \\ únicamente en emociones positivas o vivencias óptimas no sería humana.
}

Byung-Chal Han, 2014, p. 49

El concepto de experiencia recorre, como es sabido, gran parte de la historia de la filosofía y, tomado en múltiples sentidos y por diversas tradiciones, ha sido invocado para dar respuesta a un amplio espectro de problemas filosóficos. Martin Jay, en Cantos de experiencia. Variaciones modernas de un tema universal (2009), realiza una reconstrucción histórica de los usos y las transformaciones de este concepto, fundamentalmente en la modernidad y hasta fines del siglo XX. Como allí se menciona, dicho concepto "ha desempeñado un rol en virtualmente todo cuerpo sistemático de pensamiento, proporcionando una rica veta de indagación filosófica desde la época de los griegos” (2009, pp. 17-18) ${ }^{105}$. En efecto, y limitándonos sólo a aquellas corrientes contemporáneas que tienen más relevancia para nuestra investigación, cabe recordar que el concepto de experiencia ha jugado un rol importante en la fenomenología, la hermenéutica y la teoría crítica ${ }^{106}$. Husserl propone una vuelta a ese mundo de las experiencias (mundo de la vida o Lebenswelt) que es la base no sólo de todo conocimiento sino también de toda praxis. Asimismo, Gadamer recupera las experiencias extra científicas, no controladas metódicamente, que son capaces aún así de proporcionar conocimiento, en la medida en que expresan una verdad, aun cuando no se trate de una verdad verificable (Karczmarczyk, 2007).

\footnotetext{
105 Jay se centra, en su estudio, en la filosofía occidental. Aun así, sostiene que "podría ser tentador proporcionar un análisis comparativo de la manera en que el término ha operado en los léxicos de los pensadores no occidentales" (Jay, 2009, p. 18), entre los que menciona a Kitaro Nishida.

$106 \mathrm{Si}$ bien excede el campo de esta investigación, cabe mencionar la centralidad de la experiencia en el pragmatismo norteamericano clásico. Sobre la concepción pragmatista de la experiencia, cfr. Di Gregori y López (2014).
} 
En la Escuela de Frankfurt nos encontramos con lo que Jay (2009) llamará un lamento por la crisis ${ }^{107}$ de la experiencia. En efecto, y como sostiene Detlev Claussen,

la experiencia de la pérdida de la experiencia es uno de los motivos más antiguos de la Teoría Crítica, un tema que fue introducido en la década de 1920 por Kracauer y Benjamin, pensadores independientes próximos al círculo de Max Horkheimer. (Claussen, 2006, p. 21)

En opinión de Jay, los protagonistas de este lamento serían, principalmente, Adorno y Benjamin. Por nuestra parte, y como desarrollaremos en el capítulo 4, sin negar los paralelos existentes con el pensamiento de Adorno ni la ambigüedad propia del diagnóstico benjaminiano, preferimos hablar, en el caso de Benjamin, de la especificidad de su consideración de una reconfiguración de la experiencia y no del mero lamento por su imposibilidad. En este sentido, nos posicionamos también críticamente en relación con la interpretación de Agamben (2011) respecto del fin de la experiencia, como ampliaremos en el capítulo 4.

Sin pretender hacer una historia del concepto, cabe hacer mención, por último, de aquellos filósofos que se han manifestado en contra de seguir usando este término en filosofía, dada justamente su polisemia. En palabras de Jay:

Durante las últimas décadas del siglo XX hubo, en efecto, una difundida tendencia, especialmente entre quienes se rotulaban analistas postestructuralistas del discurso y de los aparatos de poder, a recusar la "experiencia" (sobre todo la "vivencia") como un fundamento simplista de la inmediatez, incapaz de registrar la naturaleza siempre ya mediada de las relaciones culturales y la inestabilidad del sujeto, el cual se supone es el portador de las experiencias. (2009, p. 17)

${ }^{107}$ Sobre la noción de crisis y sus variaciones en el marco de la filosofía de Benjamin, ver Vargas (2018). 
Jay cita el caso de Joan Wallach Scott (1991), quien advierte sobre el supuesto esencialista del sujeto portador de la experiencia y se expresa sobre esta palabra como sigue: "tomando en cuenta su utilización para esencializar la identidad y reificar al sujeto, resulta tentador abandonarla por completo" (Scott, citada por Jay, 2009, p. 17).

El giro lingüístico marca en este sentido un cierto hito, en tanto un concepto de experiencia que la entienda como "aquello que excede los conceptos y hasta el lenguaje mismo" (Jay, 2009, p. 19) sería incompatible con la pretensión de poner en cuestión toda supuesta instancia prelingüística.

Richard Rorty, en este sentido, sostuvo que habría una incompatibilidad entre la apelación a la experiencia y el giro lingüístico que caracteriza a parte de la filosofía del siglo XX (Rorty, 1998, p. 164). Incluso, como recuerda Bernstein, Rorty ha llegado a sostener que “estaríamos mejor si simplemente abandonamos toda referencia a la 'experiencia' - un término que él piensa que es excesivamente vago y confuso" (2012, p. 127). Por nuestra parte, creemos, con Jay (2009) y Bernstein (2012), que el concepto de experiencia, lejos de resultar obsoleto, es aún fructífero en los debates contemporáneos, y que es necesario asumir la tarea de delinear las redefiniciones del concepto y reevaluar su potencialidad a la luz de los problemas y planteamientos recientes ${ }^{108}$.

En lugar de contraponer "experiencia" a "lenguaje", Jay sostiene que "la 'experiencia' (...) se halla en el punto nodal de la intersección entre el lenguaje público y la subjetividad privada, entre los rasgos comunes expresables y el carácter inefable de la interioridad individual" (Jay, 2009, p. 20). Además, este divorcio entre lenguaje y experiencia puede ser evitado teniendo en cuenta la perspectiva pragmática del giro lingüístico (Naishtat, 2005 y

\footnotetext{
${ }^{108}$ En este sentido, no sólo son importantes los trabajos que recuperan concepciones contemporáneas de la experiencia, sino también aquellos que reconstruyen y permiten valorar nuevamente las concepciones modernas de la experiencia, muchas veces simplificadas desde la filosofía del siglo XX. Sobre la concepción de la experiencia de Hume, por ejemplo, central para la historia de la filosofía, ver Calvente (2017). Allí, la autora da cuenta de que en Hume la experiencia tiene, además de la función cognoscitiva que tradicionalmente se le reconoce, una importante función en la vida social y en la toma de decisiones.
} 
2010), que comprende al lenguaje como una forma de la acción, acercándolo así a la experiencia. En este mismo sentido se posiciona Scott, para quien habría que "insistir en cambio en la cualidad productiva del discurso" (citada por Jay, 2009, p. 20).

Por otra parte, Lyotard coloca al concepto de experiencia en el pasado de la filosofía cuando afirma que "la experiencia es una figura moderna: necesita ante todo un sujeto, la instancia de un yo, alguien que hable en primera persona" (citado por Jay, 2009, p. 419). En esta afirmación, creemos, Lyotard está equiparando la experiencia al modo usualmente calificado como moderno de comprenderla, para el cual es innegable la necesidad de un sujeto fuerte que funcione de núcleo de la experiencia. En Benjamin, en cambio y como detallaremos en el capítulo 5, se operan desplazamientos en el seno del concepto de experiencia que permiten comprenderla más allá del "yo" y, de hecho, como siendo imposible a instancias de un mero “yo", en tanto en su filosofía la experiencia es entendida como una elaboración colectiva.

Este carácter colectivo de la experiencia, así como el reconocimiento por parte de Benjamin de que la experiencia se elabora en el lenguaje, son dos de los puntos de principal alejamiento de su concepción de la experiencia del modo de comprenderla que, creemos, tienen en mente tanto Rorty como Lyotard, esto es, la experiencia considerada meramente en el marco del problema del conocimiento, ya sea como recolección del material por parte de un sujeto empírico, individual, como es el caso del Hume y el empirismo ${ }^{109}$, o como resultado de la actividad de un sujeto trascendental en el caso de Kant. Para Rorty, la apelación a la experiencia es incompatible con el giro lingüístico; para Lyotard, es incompatible con el cuestionamiento contemporáneo al sujeto cartesiano. Sin embargo, en Benjamin -así como también, como intentaremos mostrar en la última sección de esta investigación, en Heidegger-puede rastrearse

\footnotetext{
${ }^{109}$ La historiografía filosófica que opone racionalismo a empirismo y coloca en segundo plano otras corrientes de la filosofía moderna ha sido ampliamente cuestionada. Si bien centrarnos en estas discusiones excede los objetivos de esta investigación, consideramos que es importante tenerlas en cuenta. Para una aproximación a este debate, y a los planteos alternativos de la historiografía francesa, recomendamos ver Manzo (2016). Allí, tras dar cuenta del origen neokantiano de la historia de la filosofía que habitualmente puebla los manuales y programas, la autora presenta el análisis de Degérando, que agrupa y relaciona a los filósofos modernos con otro criterio.
} 
un concepto de experiencia que se relaciona con los sentidos compartidos acerca del mundo, y que se acerca a la acción y al lenguaje, superando la limitación moderna de la experiencia a la experiencia cognoscitiva, en tanto reconoce que otras experiencias tienen lugar en la construcción colectiva de la significación.

Agamben, en su estudio Infancia e historia. Destrucción de la experiencia y origen de la historia, al que volveremos en el capítulo 4, sostiene que "la expropiación de la experiencia estaba implícita en el proyecto fundamental de la ciencia moderna" (2011, p. 13), en tanto es desplazada por la experimentación controlada propia de la ciencia, que monopoliza todo el ámbito del saber. En este sentido, recupera una caracterización de la experiencia "común" de Francis Bacon, que es interesante reproducir:

La experiencia común no es más que una escoba rota, un proceder a tientas como quien de noche fuera merodeando aquí y allá con la esperanza de acertar el camino justo, cuando sería mucho más útil y prudente esperar el día, encender una luz y luego dar con la calle. El verdadero orden de la experiencia comienza al encender la luz; después se alumbra el camino, empezando por la experiencia ordenada y madura, y no por aquella discontinua y enrevesada; primero deduce los axiomas y luego procede con nuevos experimentos. (Agamben, 2011, p. 13)

En Benjamin, como veremos en esta sección, algo de este proceder a tientas que Bacon coloca como la experiencia común que debe ser superada por una experimentación guiada es recuperado y encuentra una valoración positiva tras el fracaso que se percibe como resultado del proyecto moderno y sus formas propias de racionalidad. Y es que en el período que nos ocupa -primera mitad del siglo XX-, la reflexión sobre la experiencia aparece ligada al análisis de los importantes cambios ocurridos en Europa, fundamentalmente a los avances de la técnica, a la vida en las ciudades y al impacto destructivo de las dos guerras mundiales. En este escenario, la pregunta por el estado concreto e incluso sobre la posibilidad misma de la experiencia se vio fuertemente incentivada, en reflexiones que anticipan la pregunta, central 
para la filosofía europea del siglo XX, acerca de la posibilidad de la experiencia en los campos de concentración.

En esta sección de nuestra investigación, y habiendo planteado ya el problema de la estetización en la filosofía de Benjamin como el diagnóstico de un cierto déficit en la implicación práctica con el mundo $\mathrm{y}$, en este sentido, como manifestación de la crisis de los sentidos compartidos, nos concentraremos en analizar esa experiencia en crisis. Partiendo, entonces, del modo en que la experiencia se alza, en el ámbito del arte, pero también en el de la historia, como la contracara posible de la estetización, tal y como sostuvimos en el capítulo 3, nos centraremos ahora, en primer lugar, en el capítulo 4, en el diagnóstico benjaminiano de una crisis de la experiencia y, en segundo lugar -en el capítulo 5-, rastreamos en la obra de Benjamin los modos en que el concepto de experiencia es redefinido y abandona los supuestos modernos que tradicionalmente cargaba para convertirse en una herramienta productiva para pensar nuestra relación con el mundo. 


\section{Capítulo 4}

\section{Una experiencia en crisis $^{110}$}

No quiero dinero. ;Quiero una vida que tenga sentido!

Miranda July, 2018, p. 165

\subsection{Introducción}

El concepto de experiencia es central en la obra de Benjamin, como atestigua la multiplicidad de trabajos académicos que intentan esclarecerlo. Así, la crítica benjaminiana al concepto kantiano de experiencia, la articulación de la posibilidad de hacer una experiencia con el pasado que interrumpa el curso de la historia, la potencialidad de la experiencia estética en el marco de la crisis de sus soportes tradicionales y el reconocimiento de la experiencia religiosa son algunos de los ámbitos problemáticos en los que la apelación al concepto de experiencia resulta ineludible. Este tópico atraviesa, además, la obra de Benjamin en toda su extensión, desde el artículo "Experiencia" [Erfahrung], que redacta en 1913, a sus 21 años, hasta su último escrito, las Tesis "Sobre el concepto de historia", de 1940, el año de su muerte.

En este marco, la crisis o el empobrecimiento de la experiencia en el siglo XX, que se relaciona de manera muy profunda con los procesos de estetización a los que nos referimos en el capítulo 3, es uno de los problemas centrales de los que es necesario dar cuenta para intentar esclarecer qué entiende Benjamin por experiencia.

\footnotetext{
${ }^{110}$ Una versión previa de este capítulo (Staroselsky, 2020b) fue publicada en Resistances. Journal of the Philosophy of History.
} 
En este capítulo, por lo tanto, nos centraremos en el diagnóstico benjaminiano de una crisis de la experiencia, trabajando, en primer lugar, con aquellos textos en los que Benjamin se refiere más explícitamente a este fenómeno, a saber, "Experiencia y pobreza”, de 1933, "El narrador", de 1936 y “Sobre algunos motivos en Baudelaire”, de 1939. Asimismo, evaluaremos algunas interpretaciones del diagnóstico benjaminiano deteniéndonos en el debate acerca de si la crisis diagnosticada por Benjamin permite vislumbrar una cierta reconfiguración de la experiencia o nos condena a pensar en su absoluta imposibilidad. Este debate, creemos, nos invita a enfocarnos en la pregunta acerca de la actualidad de Benjamin, que tan bien ha planteado Hansen. En sus palabras:

Benjamin está hoy en pleno apogeo, pero ¿tiene todavía actualidad? Esta pregunta es inevitable en una época en la que nuestra vida personal, social y política parece estar, más que nunca, impulsada por el desarrollo de la tecnología de medios y, por lo tanto, por una transformación, desintegración y reconfiguración aceleradas de las estructuras de la experiencia. (Hansen, 2012, p. 75)

La pregunta por la actualidad de Benjamin no es, cabe aclararlo, la mera pregunta por la vigencia de su pensamiento para pensar el presente. Más allá de la productividad de las ideas del autor y como expone Luis García, "lo que aquella pregunta activa es la interrogación por la historicidad, por la transmisibilidad, de una obra en la que las concepciones tradicionales de historia y transmisión estallaron por los aires" (2013, p. 1).

A partir, entonces, del diagnóstico benjaminiano, y entendiéndolo como la advertencia de algunos peligros que hace falta atender más que como la constatación nostálgica del fin de una era, nos proponemos pensar en las posibilidades de supervivencia de la experiencia tras su crisis y en los modos en que esta nueva experiencia podría tener lugar. Siguiendo a Collingwood-Selby, nos centraremos en la potencialidad del arte y de la escritura de la historia como dos ámbitos donde las experiencias deben ser elaboradas y pueden serlo, para Benjamin, 
de un modo crítico. En efecto, y contrariamente a lo que los discursos ligados a la representación han sostenido, el arte y la historia no reflejan la realidad, sino que funcionan generando dispositivos o aparatos que dan forma a nuestra relación con el pasado y con el mundo que nos rodea, moldeando nuestra sensibilidad.

\subsection{El diagnóstico benjaminiano}

Toda atrofia que nos disminuya, aun con la mejor excusa evolutiva, nos inquieta. Y quizá tenemos un motivo serio de preocupación.

César Aira, 2001, p. 4

Benjamin da cuenta de la crisis o el empobrecimiento de nuestra experiencia más de una vez a lo largo de su producción, y en todos los casos, más o menos explícitamente, es a partir de la descripción de aquello que se encuentra amenazado o, al menos, en un proceso de profunda modificación, que podemos encontrar algunas pistas que nos permitan reconstruirlo. La crisis de la experiencia se convierte así en un punto de acceso privilegiado para desentrañar la estructura misma de aquella relación con el mundo que se desvanece y para vislumbrar sus potencialidades y sus límites, a la vez que abre una perspectiva para comprender lo que se alza tras ese declive. Déotte lo expresa bien cuando sostiene que en Benjamin la "filosofía de la ciudad se establece a partir de aquello que no es ella: el mundo de los campesinos, artesanos y marinos, mundo del aura, de la transmisión real de la profundidad de los acontecimientos" (2013, p. 57). Nos adentraremos también, con los lentes de nuestra época, en el estudio benjaminiano de aquello cuya posibilidad está puesta en duda ya en la década del 30. 
El diagnóstico más explícito de una crisis de la experiencia se encuentra en "Experiencia y pobreza"111, de 1933. Allí, lo que textualmente postula Benjamin es que "la cotización de la experiencia se ha venido abajo [die Erfahrung ist im Kurse gefallen]" (Benjamin, 2007a, p. 217). Los hombres que volvieron de la guerra -se refiere a la Primera Guerra Mundial, sostiene, no lo hicieron enriquecidos por los acontecimientos que presenciaron y de los que formaron parte sino devastados, empobrecidos y sin capacidad de compartir lo vivido con su comunidad. No parecen haber aprendido nada.

El modo en que este hecho se expresa, el síntoma del que parte Benjamin, es la incapacidad de estos hombres de comunicar sus experiencias, esto es, su mudez. Se revela así que, para Benjamin, una experiencia no es cualquier vivencia subjetiva, ni cualquier encuentro con el mundo, sino que implica una elaboración de ese material en la forma de un relato significativo para otros. La crisis de la experiencia es, en realidad, la constatación del hecho de que "una facultad que nos parecía inalienable, la más segura entre las seguras, nos fuese arrebatada. Tal, la facultad de intercambiar experiencias [das Vermögen, Erfahrungen auszutauschen]" (Benjamin, 2008, p. 60; GS II 439).

El nexo entre experiencia y narración, que ha sido ya ampliamente destacado (Di Pego, 2015, 2018; Honold, 2014; Weber, 2014) se hace aquí evidente, y nos permite, analizándolo, comprender que lo que para Benjamin hará falta para que puede hablarse de experiencia será, más que un acontecimiento memorable, dos de los elementos que configuran una tradición, a saber, lenguaje y comunidad. La mudez de los soldados no es una mudez individual, sino colectiva: expresa que no hay un lenguaje en el que elaborar lo vivido y que, sin este lenguaje común, sin herramientas para la transmisión y la comunicación, no hay comunidad posible.

\footnotetext{
${ }^{111} \mathrm{El}$ artículo (cuyo título original es "Erfahrung und Armut") fue publicado en diciembre de 1933 en la revista Die Welt im Wort.
} 
Volviendo al texto, cabe detenerse en primer lugar en el modo en que está construido: "Experiencia y pobreza" comienza con la fábula de Esopo "El labrador y sus hijos", en la que un anciano les lega a sus hijos, en su lecho de muerte, una experiencia, a saber, que "la riqueza no está en el oro, sino en el esfuerzo [Nicht im Golde steckt der Segen sondern im Fleiß]" (Benjamin, 2007a, p. 217; GS II 213-214). Sin embargo, esto no es dicho por el moribundo, sino que sus palabras motivan una acción a través de la cual los hijos lo descubren por sí mismos: como narra Benjamin, lo que hace el anciano es asegurarles a sus hijos que hay un tesoro enterrado en la viña, lo que los incita a poner todo su esfuerzo en excavar para encontrarlo. Tras remover la tierra, los herederos no encuentran tesoro alguno, pero logran una muy buena cosecha por el buen estado de la tierra; al ver que el viñedo era el más productivo del país, comprenden que "su padre les había legado una experiencia [der Vater gab ihnen eine Erfahrung mit]" (Benjamin, 2007a, p. 217; GS II 213).

Aparece entonces una primera caracterización de la experiencia, aunque en pasado: “ahí estaba muy claro qué representaba la experiencia: los mayores se la daban a los jóvenes [immer hatten die älteren Leute sie an die jüngeren gegeben]" (2007a, p. 217; GS II 214), "las han ido esgrimiendo ante nosotros, amenazándonos o tranquilizándonos, mientras crecíamos [hat man uns, drohend oder begütigend, so lange wir heranwuchsen entgegengehalten]" (2007a, p. 217; GS II 214). El modo en que se opera la transmisión de esa experiencia, ligado a la tradición y a las instituciones que le son propias, se hace evidente: es necesario un lenguaje común entre las generaciones, un marco de sentido compartido que permita la circulación de relatos y refranes "junto a la chimenea, delante de los hijos y los nietos" (2007a, p. 217), y es necesaria también una cierta autoridad ${ }^{112}$ de los ancianos y los saberes que portan, fundada en la certeza de que resultan aún fructíferos para sus hijos y sus nietos. Para esto, el mundo debe ser, al

\footnotetext{
${ }^{112}$ Benjamin se refiere críticamente a esta autoridad de la edad en su breve texto temprano "Experiencia" [Erfahrung].
} 
menos en alguna medida, el mismo ${ }^{113}$. De una forma similar, ya en "Panorama imperial" [Keiserpanorama], un texto incluido en Calle de mano única, se refiere Benjamin a los refranes de este tipo como "esos refranes [Sprüchlein] que alguna vez se pudo dar por válido, pero cuya fecha de vencimiento [Verfalltag] expiró hace tiempo"114 (2014, p. 58; GS IV 96).

Volviendo a "Experiencia y pobreza", habiendo presentado este fenómeno, se pregunta Benjamin:

¿Qué fue de todo eso? ¿Dónde podemos encontrar a alguien que sepa aún relatar bien algo? [Wer trifft noch auf Leute, die rechtschaffen etwas erzählen können?] ¿Dónde hay moribundos que digan frases que pasen de generación en generación, al modo de un anillo? ¿Quién se acuerda ahora de un refrán? ¿Y quién intentará despachar a la juventud apelando así a la experiencia? [Wer wird auch nur versuchen, mit der Jugend unter Hinweis auf seine Erfahrung fertig zu werden?]. (2007a, p. 217; GS II 214)

Recién en ese momento del texto viene el diagnóstico que mencionábamos anteriormente: "la cotización de la experiencia se ha venido abajo, y ello además en una generación que, entre 1914 y 1918, ha hecho una de las experiencias más tremendas de la historia [eine der ungeheuersten Erfahrungen der Weltgeschichte gemacht hat]" (2007a, p. 217). La paradoja es evidente: para la forma tradicional de comprender la experiencia, o mejor, teniendo en cuenta su cotización tradicional, protagonizar un acontecimiento de la envergadura de la Primera Guerra Mundial debería venir aparejado de un sinfín de historias para contar y otros tantos consejos para dar sobre la vida, la muerte, el sacrificio y otros tópicos heroicos.

\footnotetext{
${ }^{113}$ En este punto, las reflexiones de Benjamin se cruzan con las de Wittgenstein. Algunas de estas afinidades, en las que no nos centraremos aquí, fueron exploradas por Stanley Cavell (1999) y Blair Ogden (2010). Particularmente relevante es el estudio de Alexander Stern, The Fall of Language: Benjamin and Wittgenstein on Meaning (2019).

${ }^{114}$ El refrán al que refiere específicamente Benjamin en este texto es "Pobreza no es vileza". En un pasaje que impacta por su actualidad, reflexiona sobre el impacto de la pobreza estructural que "cae como una una sombra gigantesca" (2014, p. 58) sobre pueblos y hogares, y la distingue de la pobreza propia de una mala racha o un infortunio, aquella de "cuando había trabajo que alimentaba al hombre" (2014, p. 58).
} 
Sin embargo, no es el caso: la autoridad de los combatientes se ve ensombrecida por su incapacidad de narrar lo vivido, ya que "ninguna experiencia fue desmentida con más rotundidad que las experiencias estratégicas por la guerra de trincheras" (Benjamin, 2007a, p. 217). Y es que el "despliegue formidable de la técnica [ungeheuren Entfaltung der Technik]" (2007a, p. 217; GS II 214) al que se refiere Benjamin en el texto se manifiesta, en la gran guerra, tanto en las novedades armamentísticas como en la estrategia, volviendo al acontecimiento imposible de narrar.

Gabrielle Rosenthal, en un estudio de 1990, da cuenta del fenómeno de la ausencia de relatos típicamente bélicos en el discurso de los ex combatientes de la Primera Guerra. En sus palabras:

en la República Federal Alemana de hoy, la Segunda Guerra Mundial es un tema actual que se discute con entusiasmo tanto en privado como en público. En nuestras entrevistas con veteranos de la Primera Guerra Mundial, sin embargo, hubo una notable falta de narración sobre el tiempo pasado en las trincheras. (1990, p. 119)

La mudez de los soldados alemanes que combatieron en la Primera Guerra Mundial, como observa Benjamin en "El narrador", fue cubierta por "la marea de los libros de la guerra" (2008, p. 60) que apareció a diez años de su fin y que contenía "todo lo contrario de una experiencia que se transmite de boca en boca" (2008, p. 60). Se trata, otra vez, de aquella galvanización a la que nos referíamos en el capítulo anterior: en el contexto de una crisis significativa que cuestiona aquello que se creyó incuestionable, los vacíos se cubren y las interferencias se ocultan detrás de una fingida plenitud. Aun así, debajo del grueso manto de información y análisis sobre la guerra, la voz de los combatientes se siguió articulando con dificultad hasta su muerte, como demuestra Rosenthal a partir de su serie de entrevistas: 
El ejemplo más excepcional de la no narrabilidad de este periodo lo hallé en la narración de un hombre que había descrito en detalle su instrucción básica y sus primeros días en el cuartel, pero en cuanto quiso empezar a explicarme la época que pasó en las trincheras, la mente se le quedó totalmente en blanco, no conseguía recordar nada. Mis preguntas fueron en vano. Solo fue capaz de continuar su narración cuando le pedí que me hablara sobre el final de la guerra. (1990, p. 120)

En efecto y como constata la investigadora, "el relato que falta sobre el periodo de las trincheras es un fenómeno generalizado en las entrevistas que llevamos a cabo con hombres, la mayoría de los cuales habían servido como soldados en ambas guerras" (Rosenthal, 1990, p. 120). Las narraciones de tono épico y plagadas de acontecimientos dramáticos que aparecen en los relatos de la Segunda Guerra están ausentes, según Rosenthal, en los recuerdos de la Primera. A diferencia de la Segunda Guerra Mundial (una guerra de movilidad), la "de la Primera Guerra Mundial fue una experiencia de la vida en las trincheras donde era imposible orientarse en base al tiempo, o estructurar los días de acuerdo con las secuencias de un dia normal" (1990, p. 122) $)^{115}$, en tanto los soldados pasaban, en ocasiones, meses y hasta años inmóviles en estos pequeños y precarios espacios (1990, p. 122), alejados de cualquier tipo de enfrentamiento o batalla, esto es, de cualquier experiencia bélica esperable.

Más allá de este rasgo estratégico que la convierte en una guerra de espera y desgaste, la Primera Guerra se caracterizó también por el despliegue técnico de armamento, fundamentalmente el de ametralladoras, que le confirió un poder destructivo difícil de dimensionar. Con respecto a este fenómeno, dice Benjamin en "Experiencia y pobreza":

Una generación que fue al colegio todavía en tranvía de caballos se encontraba ahora a la intemperie y en una región donde lo único que no había cambiado eran las nubes; y ahí, en medio de ella, en un campo de fuerzas de explosiones y torrentes

\footnotetext{
${ }^{115}$ Como menciona Rosenthal, Ernest Hemingway también da cuenta de esta particular experiencia de guerra en su novela Adiós a las armas, de 1929.
} 
destructivos, el diminuto y frágil cuerpo humano [winzige gebrechliche Menschenkörper]. (2007a, p. 217; GS II 214)

En este pasaje no sólo está en juego la caracterización del tipo específico de vivencia que significó la guerra -y su carácter de shock, como señala Weber (2014)-, sino también la desmesura entre el acontecimiento y el sujeto que lo vivencia o mejor, lo que queda de aquel sujeto: incapaz de elaborar lo que allí sucede, enmudecido y empequeñecido, reducido a su sola corporalidad $^{116}$, el ser humano se encuentra en el seno de un escenario que no logra comprender.

Lo que aquí se manifiesta como uno de los temas que articulan el escrito es la cuestión de la técnica, que en "Experiencia y pobreza" excede a la guerra, aunque esta se plantea como el ejemplo más claro de su poder destructivo. Las innovaciones técnicas se exponen, en efecto, como uno de los motivos de la pobreza de experiencias que caracteriza a la época.

“Benjamin, tecnófilo o tecnófobo?” (Déotte, 2013, p. 155) es una pregunta que, como tantas otras de similar estructura, intenta, no tanto esclarecer, sino más bien etiquetar la filosofía de Benjamin en función de una dicotomía preestablecida. La valoración benjaminiana de la técnica es muchas veces ambivalente (Hansen, 2012, p. 79), e incluso qué se define como un aparato técnico y qué no en el contexto de la filosofía de Benjamin daría lugar a una discusión. Aun así, podemos afirmar que lo que resulta problemático en el contexto de este escrito es fundamentalmente la relación que el hombre entabla con la técnica, en la medida en que no está integrada a su experiencia, que tiene aún los marcos de lo artesanal. El modo de hacer experiencia que está en crisis, el único conocido, el de la narración y la tradición oral, no puede contener en sus marcos los nuevos acontecimientos a los que el hombre (ese que fue al colegio

\footnotetext{
${ }^{116}$ Benjamin usa dos palabras para nombrar aquello que en español denominamos cuerpo: Leib y Körper. Como repone Barbisan (2017), la diferencia se remonta a la tradición fenomenológica, para la cual Leib representa al cuerpo vivido, mientras que Körper se refiere al cuerpo en tanto que objeto que interactúa con el mundo y que es visto y sentido por otros. Max Scheler se refiere a esta distinción en 1916, y Husserl la toma en 1918. Benjamin, por su parte, ya en un fragmento de 1918 parece dar cuenta de dos sentidos de la corporalidad en sus propios términos. En este fragmento de "Experiencia y pobreza" Benjamin utiliza el término Körper. Sobre la importancia del cuerpo en Benjamin, recomendamos consultar el clásico estudio de Weigel (1999) y Steiner (2001).
} 
en tranvía de caballos) se enfrenta, en un mundo estructurado violentamente por aparatos técnicos.

“La experiencia”, dirá Benjamin algunos años más tarde, “es cosa de la tradición, lo mismo en la vida colectiva que en el interior de la vida privada [In der Tat ist die Erfahrung eine Sache der Tradition, im kollektiven wie im privaten Leben]" (2008c, p. 209; GS I 608). Y lo que está en juego en esta época es, en fin, el fenómeno que Amengual denomina como "ruptura de la tradición”, en el que los cambios técnicos adquieren una importancia enorme. Nos permitiremos citarlo extensamente:

Lo que queda claro es que con la pérdida de la experiencia se pierde, no un elemento cognitivo cualquiera, sino la capacidad de percibir lo que se vive, la capacidad de integrarlo en la vida, de compartirlo con los demás y de transmitirlo. La pérdida de la experiencia apunta, entonces (...) a la ruptura con las formas de vida y de pensar practicadas a lo largo de los siglos, ruptura, por tanto, de una forma de vida histórica; señala una ruptura de la tradición. (...) Esta ruptura se vive como un empobrecimiento de la realidad y del sujeto: la realidad misma parece haber perdido densidad, dimensiones que le eran propias; la realidad se ha reducido a rango mínimo. El sujeto no sólo ha perdido consejo, orientación en la vida, sino incluso la capacidad de percepción, de compresión, de apertura a nuevas experiencias, como si su órgano sensorial y mental se hubiera reducido o incluso atrofiado. (2008, p. 57)

En esta pérdida de la capacidad de percepción, en la atrofia de la capacidad de experimentar, aparece ese rasgo anestésico característico de los diagnósticos de una relación estetizada con el entorno que trabajamos en la primera sección de esta investigación.

En efecto, la ruptura de la tradición implica un quiebre en las formas de vida que, lejos de ser externas al sujeto, le son constitutivas y en las que el estado de la técnica es decisivo. Déotte, en su estudio La ciudad porosa. Walter Benjamin y la arquitectura, propone una definición de "contemporáneo" que creemos ayuda a ilustrar este fenómeno. Basándose en la 
idea benjaminiana de que la ciudad está configurada por aparatos, y en su análisis de cómo nuestra experiencia y percepción se ven modificadas en las diferentes épocas históricas, Déotte propone pensar que contemporáneos serán aquellos cuya experiencia se encuentre estructurada por los mismos aparatos. Debatiendo con Agamben, sostiene:

Si cada aparato hace época y hace mundo, es él el que hace a los hombres contemporáneos. Nos separamos aquí de la concepción que desarrolla Agamben de la contemporaneidad, para el cual serán contemporáneos los hombres que critican el mismo estado de la sociedad. (2013, pp. 98-99) ${ }^{117}$

Y es que para Déotte, con quien coincidimos, "Benjamin ha sido un pensador de la técnica (...) de una manera no anecdótica, sino esencial" (2013, p. 103), en tanto percibió la importancia de los aparatos técnicos y ópticos entre los que nos movemos como piezas fundamentales de nuestra formación y nuestra experiencia del mundo. A su vez, la técnica adquiere una relevancia particular en su pensamiento acerca de la tradición y de las formas de transmisión que caracterizan a cada época.

Como destaca Weber, "Benjamin responsabiliza del hecho de que estas experiencias ya no pudieran ser comunicadas no solo a su contenido ('shockeante'), sino también a la transformación de las formas de comunicación" (Weber, 2014, p. 511). En efecto, la crisis de la experiencia hace alusión, como vimos para el caso de los soldados, a la imposibilidad de que las vivencias individuales sean elaboradas colectivamente por los sujetos en la narración. Es así que la incapacidad de intercambiar experiencias, como síntoma principal de la crisis de la experiencia, pone en evidencia la centralidad de las formas de comunicación y elaboración de lo vivido en la crisis que se constata. Los soportes de esas experiencias que supieron ser

\footnotetext{
${ }^{117}$ La evaluación de la lectura que Déotte hace de Agamben excede el alcance de esta investigación. Sobre ella, Didi-Huberman tiene una lectura muy diferente, y sostiene que para Agamben "ser contemporáneo sería (...) oscurecer el espectáculo del siglo presente con el fin de percibir, en esa oscuridad misma, la 'luz que trata de alcanzarnos y no puede"” (2012a, p. 53).
} 
transmitidas de generación en generación están en crisis. Déotte los denomina, en diálogo con el concepto de "superficie de inscripción" que desarrolló Lyotard, "superficies de (re)producción” (2013, p. 99).

La narración, entendida también como técnica, en tanto "hay verdaderamente una técnica de la narración, si no todos los narradores tendrían el mismo valor" (Déotte, 2013, p. 103), es entendida como una superficie de reproducción, como lo será luego el periódico, la radio y el cine. Pero en la crisis de la experiencia, dirá Déotte:

el habitante de las ciudades modernas sabe que no puede contar las huellas en su memoria y que no se conservará ninguna huella de su existencia, puesto que en la ausencia de narración, es decir en la ausencia del aparato comunitario que hace posible la experiencia en el sentido de la tradición, ya no hay más superficie de inscripción de huella. (2013, p. 57)

Los pobres en experiencia, o los nuevos bárbaros, como los llama Benjamin en "Experiencia y pobreza", "no son siempre ignorantes o inexpertos [unerfahren] y a menudo se puede decir todo lo contrario: ellos han 'devorado' todo eso [sie haben das alles 'gefressen'], 'la cultura' y, con ella, el 'ser humano', y están ahítos y cansados [sie sind übersatt daran geworden und müde]" (2007a, p. 221; GS II 218). La falta no está en la información ni en la vivencia, sino en la forma específica de elaboración de lo vivido y lo percibido que Benjamin llama experiencia [Erfahrung].

Tanto aquello que se percibe o se vivencia como aquello que se lee o se ve pierde espesura y significación para la comunidad cuando no logra ser elaborado en la experiencia, como queda claro en la pregunta retórica que lanza Benjamin acerca del carácter poco productivo de la cultura "cuando la experiencia no nos conecta con ella" (2007a, p. 218), y a la que nos referimos en el capítulo 3. Esa cultura se degrada a mero acervo, se museifica o se convierte en mera información, distanciándose de la experiencia y del cuerpo de los hombres. 
El narrador y "Sobre algunos motivos en Baudelaire" 118 son dos textos que dialogan con "Experiencia y pobreza", en tanto replican el diagnóstico principal que Benjamin realiza allí y suman elementos que enriquecen el análisis. En ambos, el autor pone mucho énfasis en separar la experiencia de la información; separación en la que nos interesa detenernos en tanto es relevante no sólo para una descripción de la crisis de la experiencia, sino también para comprender cómo algunos rasgos que resultan clave en la caracterización de los procesos estetizantes aparecen en este contexto, en tanto la información delimita una forma precisa de elaboración de los acontecimientos radicalmente diferente de la manera en que los hila la narración.

En "Sobre algunos motivos en Baudelaire"119, Benjamin da cuenta de cómo el trabajo de la prensa se ocupa de "impermeabilizar los acontecimientos frente al ámbito en el que pudieran afectar a la real experiencia del lector [die Ereignisse gegen den Bereich abzudichten, in dem sie die Erfahrung des Lesers betreffen könnten]" (2008c, p. 211; GS I 610) ${ }^{120}$. Los "principios de la información periodística" que Benjamin enumera, "novedad, brevedad, comprensibilidad y ante todo desconexión de unas y otras noticias entre sí [Neuigkeit, Kürze, Verständlichkeit und vor allem Zusammenhanglosigkeit der einzelnen Nachrichten untereinander]" (2008c, pp. 211-212; GS I 610), colaboran para poner a los acontecimientos a una distancia que los haga inaccesibles para la experiencia, ya que en la información, como señala Oyarzún, no se busca proporcionar elementos de orientación en el mundo: su matriz es cognitiva y no pragmática $(2008$, p. 24).

\footnotetext{
118 Este escrito no se centra solamente en Baudelaire, sino que analiza y se nutre también de otras figuras, fundamentalmente de las de Bergson, Proust y Freud.

${ }^{119}$ Si bien aquí no nos centraremos en la recepción benjaminiana de Baudelaire, cabe destacar que su importancia desborda por mucho la temática a la que aquí nos ceñimos. En efecto, Baudelaire aparece en la correspondencia de Benjamin ya en 1915, y a partir de allí Benjamin le dedica varios escritos además del que aquí citamos, a saber, "Das Paris des Second Empire bei Baudelaire", "Notes sur les Tableaux parisiens de Baudelaire" y "Zentralpark", así como muchísimas menciones en su Obra de los pasajes, fundamentalmente en el convoluto J. Sobre los textos de Benjamin sobre Baudelaire véase Schmider y Werner (2011).

${ }^{120}$ También en la Obra de los pasajes se replica esta crítica a la prensa. Sobre ella, dirá Benjamin que "viene siempre presentando un incesante exceso informativo cuyo estímulo es tanto más intenso cuanto más se sustrae a cualquier tipo de real y concreta utilidad" (2013, p. 718).
} 
Al referirse a Karl Kraus, Benjamin recuerda en esta misma línea que "no se cansó de señalar hasta qué punto el hábito lingüístico propio de los periódicos paraliza la imaginación de sus lectores" (2008c, p. 212), en tanto entrega el material ya procesado. La cerrazón de la pieza periodística impide que el lector trabaje con ella de la misma forma en que elaboraba el material de la narración en la escucha. Mediante la explicación, la información cumple un ciclo tras el que queda obsoleta sin dejar huella. Asimismo, "la impermeabilización de la información frente a la experiencia [die Abdichtung der Information gegen die Erfahrung] también depende del hecho de que la primera no entra en la 'tradición' [nicht in die 'Tradition' eingeht]" (Benjamin, 2008c p. 212; GS I 611). En efecto, mientras que la experiencia se teje en el entramado social y depende de relaciones intersubjetivas e intergeneracionales, la información se maneja en una esfera separada del todo social.

En este mismo sentido, Thomas Weber, en su estudio sobre la experiencia, comparándola con la información, sostiene que "la información, conforme a su estructura, permanece ajena a la experiencia del receptor, cuanto más se le impone en la forma de explicaciones respecto de la cosa" (2014, p. 513), y agrega: “el efecto de la información es, por ende, volver pasivo; el de la narración, activar al receptor” (2014, p. 514). Y es la narración y la experiencia suponen un tipo de elaboración del material de la vivencia que dista mucho del tipo de proceso que se da en la información.

La "nueva forma de la comunicación”, que es ya la información (Benjamin, 2008, p. 67) tiene en su centro a la matriz de la explicación, de la que la narración prescinde. Como explica Honold en su estudio, "Benjamin sitúa históricamente la narración al comienzo de una serie evolutiva de formas de comunicación (...) en cuyo curso el contenido de la experiencia es reemplazado, en forma creciente, por el valor de la vivencia" (2014, p. 797). Volveremos sobre el concepto de vivencia [Erlebnis] en el próximo capítulo. Por ahora, nos interesa destacar cómo la experiencia aparece ligada a la narración como aquello que la hace posible. 
En este punto aporta claridad un pequeño apartado del texto "Breves malabarismos artísticos" [Kleine Kunst-stücke], que Benjamin titula "El arte de narrar" [Kunst zur erzählen]. Allí, observa que "ya no nos llega ningún acontecimiento que esté libre de datos explicativos [die nicht schon mit Erklärungen durchsetzt ist]" (2011b, p. 163; GS IV 436) y dice sobre la narración, oponiéndola fundamentalmente al discurso informativo de la prensa:

El mérito de la información pasa, en cuanto esta deja de ser novedad. Ella sólo vive en ese momento. Debe entregarse a él y explicarse sin perder tiempo. Pero con el relato sucede otra cosa: no se agota, sino que almacena la fuerza reunida en su interior y puede volver a desplegarla después de largo tiempo [sie verausgabt sich nicht. Sie bewahrt ihre Kraft gesammelt im Innern und ist nach langer Zeit der Entfaltung fähig]. (2011b, p. 163; GS IV 437)

Resulta clave, en este punto, el caso de la historia del rey egipcio Samético, de Heródoto, que trae Benjamin a colación para ilustrar este punto. De ella dice:

de lo que no cabe duda es de que todos los periodistas la explicarían en un abrir y cerrar de ojos. Heródoto no la explica ni con una palabra [Herodot erklärt sie mit keinem Wort]. Su relato es el más seco. Por eso esta historia del antiguo Egipto puede provocar asombro y reflexión [Staunen und Nachdenken] aún hoy, después de milenios. (2011b, p. 164, GS IV 438)

Crisis de la experiencia y crisis de la narración se revelan como dos caras de la misma moneda, en tanto la narración funcionó, como mencionamos, como el aparato que tradicionalmente articuló y moldeó la experiencia. Teniendo en cuenta que "una época se define no por los acontecimientos, sino por el modo de aprehender esos acontecimientos" (Déotte, 2013), El narrador se articula en torno a la compleja relación entre la crisis de la narración y la crisis de la experiencia. Allí, "la narración no es considerada a partir de su condición de 
objeto literario autónomo (...), sino como la instancia en que puede ser ejemplarmente examinada la catástrofe de la experiencia en el mundo moderno" (Oyarzún, 2008, p. 9).

La temática del texto, en tanto analiza aquello que en el presente se difumina, traza una peculiar relación con el ensayo sobre la obra de arte y su tematización de la crisis del arte aurático. Benjamin describe, una vez más, un paisaje en ruinas que a la vez habita.

Las ruinas, como productos de la devastación, pero también de una destrucción que Benjamin oscila en celebrar o temer, tienen un lugar privilegiado en la filosofía de Benjamin, de manera más o menos explícita. En "Experiencia y pobreza", conforman el escenario de una nueva barbarie, que encarna la posibilidad de comenzar de cero. “¿Barbarie? En efecto. Pero lo decimos para introducir un concepto nuevo de barbarie, positivo [einen neuen, positiven Begriff des Barbarentums]" (2007a, p. 218; GS II 215), dirá Benjamin. Con este concepto positivo de barbarie Benjamin parece alejarse de una posición nostálgica que sueña con retornar a un pasado de mayor significatividad. Sobre la pobreza de experiencias, plantea:

esto no hay que entenderlo en el sentido de que la gente desee una experiencia nueva. No, bien al contrario: quieren librarse de las experiencias [sich von Erfahrungen freizukommen], desean un entorno en el que puedan manifestar sin más, pura y claramente, su pobreza (exterior e interior), es decir, que surja algo decente [etwas Anständiges]. (2007a, p. 221; GS II 218)

La actitud que Benjamin describe en este fragmento, y que identifica con artistas como el arquitecto Adolf Loos y el escritor Paul Scheerbart, entre otros, se caracteriza no tanto por celebrar la pobreza de experiencias, sino más bien por darle lugar, para en todo caso darle respuesta.

Lo que se evita con esta actitud es la galvanización. Como indicamos en el capítulo 3, Benjamin usa este término para dar cuenta de la falsedad que implica fingir que aquello que agoniza goza todavía de buena salud. En "Experiencia y pobreza", Benjamin hace dos 
referencias en este sentido: en primer lugar, anota, al hablar de la miseria que sobrevino a la guerra y al despliegue de la técnica, que

el reverso de dicha miseria es la sofocante riqueza de ideas que se ha difundido entre la gente (o que, más bien, se le vino encima) con la consiguiente reanimación de la astrología y el yoga, de la christian science y la quiromancia, del vegetarianismo y la gnosis, de la escolástica y el espiritismo. (2007a, pp. 217-218)

Allí, en un pasaje que creemos muy actual -y al que nos referimos brevemente en el capítulo 3- se refiere a la puesta en marcha de estrategias que buscan dar sentido en un contexto de crisis en el que las formas mismas de significar se tambalean, y las caracteriza como galvanizaciones y no verdaderas reanimaciones. La emergencia súbita, mezclada y confusa de actividades y creencias que buscan cubrir el vacío que deja la pobreza de experiencias, al mostrar el esforzado intento por dotar de sentido un mundo en el que ya no se sabe producir sentidos, da cuenta del alcance de la crisis de la experiencia.

En segundo lugar, y más explícitamente, dice Benjamin: "Adónde conduce simular experiencias nos lo ha dejado demasiado claro esa horrible mezcla de varios estilos y cosmovisiones del pasado siglo [das grauenhafte Mischmasch der Stile und der Weltanschauungen im vorigen Jahrhundert], como para que no consideremos honorable admitir nuestra pobreza" (2007a, p. 218; GS II 215). La posición del autor es, en este punto, clara: se asociará, al menos en la dicotomía que postula este texto, entre la galvanización nostálgica y la aceptación de la nueva barbarie, con la tradición de aquellos "grandes creadores" [großen Schöpfern] (Benjamin, 2007a, p. 218; GS II 215) que ha habido en todas las épocas y que "han hecho tabla rasa" (2007a, p. 218), entre los que se cuentan figuras tan disímiles como Descartes, Einstein y Klee. La actitud por la que se interesa Benjamin no es específicamente la de la fundación de lo nuevo, sino aquella ligada a la honestidad que implica dejar de sostener 
con el propio trabajo el orden existente y dar lugar a lo nuevo, aun cuando deba surgir de los puros desechos. Quienes pugnan por este salto al vacío

se apartan de la imagen propia del hombre tradicional, siempre solemne y noble, adornado con todas las diversas ofrendas del pasado, para dirigirse por su parte al contemporáneo desnudo que, gritando como un recién nacido, se encuentra en los sucios pañales de esta época [stoßen vom hergebrachten, feierlichen, edlen, mit allen Opfergaben der Vergangenheit geschmückten Menschenbilde ab, um sich dem nackten Zeitgenossen zuzuwenden, der schreiend wie ein Neugeborenes in den schmutzigen Windeln dieser Epoche liegt]. (2007a, p. 219; GS II 216)

Tal y como con el arte aurático, la mirada de Benjamin no escapa necesariamente de la nostalgia, pero se aparta de la "reacción restauradora" (Galende, 2009, p. 178) ligada tradicionalmente a ella, a saber, la de quien se rehúsa a elaborar el duelo por el estado de cosas perdido $^{121}$. Los artistas a los que se refiere Benjamin apuntan, no a reponer lo perdido a cualquier costo, sino a comprender el proceso mismo de reconfiguración de lo humano del que son testigos y protagonistas. En este sentido, refiriéndose a Scheerbart, dice Benjamin: "se interesa por la cuestión de en qué criaturas completamente nuevas, dignas sin duda alguna de estudio y de amor [gänzlich neue sehens- und liebenswerte Geschöpfe], han convertido nuestros telescopios, nuestros aviones y nuestros cohetes a los seres humanos anteriores [den ehemaligen Menschen]" (2007a, p. 219; GS II 216).

En este contexto, otra figura relevante es la de Proust. En el texto sobre Baudelaire, Benjamin reconoce en Proust un intento de producir un tipo de experiencia que está en crisis pero que, lejos de identificarse con un proceso galvanizante o de mera falsificación, saca su fuerza de la conciencia de esa artificialidad que lo signa. En su novela, Proust intentó, "bajo

\footnotetext{
${ }^{121}$ En este sentido, Cabot (2008) sostiene que Benjamin es un "anti-tradicionalista" (p. 66) y define al tradicionalismo como la postura de quien "toma una configuración concreta de la tradición, dada en un momento y situación histórica concretos, como definitiva, canónica y, por lo tanto, inamovible; después de lo cual se aferra a su defensa a ultranza" (p. 66).
} 
las presentes condiciones sociales, producir la experiencia por una vía sintética justamente tal como Bergson la concibe [die Erfahrung (...) unter den heutigen gesellschaftlichen Bedingungen auf synthetischem Wege herzustellen], pues cada vez podemos contar menos con su génesis por la vía natural” (2008c, p. 210; GS I 609). Benjamin se refiere en este pasaje específicamente a la cuestión de la memoria, en torno a la cual compara las posiciones de Bergson $^{122}$ y de Proust en tanto ambos reflexionaron sobre la relación entre la experiencia y la memoria. En el caso de Bergson, Benjamin será crítico del modo en que define la memoria pura sin atender a los cambios históricos que la época de la gran industria imprime a la estructura misma de nuestra experiencia (Schmider y Werner, 2011, p. 575). Sobre Proust, cuya exploración de la memoria involuntaria ejerció una gran influencia en su filosofía, dirá Benjamin que, si bien intenta producir con su escritura una experiencia de un tipo que ya no es posible que se de naturalmente, "en su obra no se sustrae a debatir esta cuestión. Incluso pone en juego un nuevo momento, que encierra en sí una crítica inmanente a las formulaciones bergsonianas" (2008c, p. 210) ${ }^{123}$. Asimismo, en la preeminencia que da Proust a la memoria involuntaria (y la debilidad que reconoce en la memoria voluntaria, ligada a la inteligencia), es posible encontrar una crítica a la subjetividad moderna a la vez que el reconocimiento de la agencia de los objetos, que pueden retrotraernos a los viejos tiempos.

La crisis de la experiencia tiene, como queda claro, un gran alcance: en el arte y en la literatura, se manifiesta en la crisis de la experiencia estética tradicional y de los soportes en los que se asentaba; políticamente, da lugar a movimientos conservadores que prometen el retorno de aquel pasado que despierta nostalgia y que moviliza estas emociones para ponerlas al servicio de la más extrema violencia; antropológicamente, abre la pregunta acerca de en qué

\footnotetext{
${ }^{122}$ En Infancia e historia, Agamben se refiere críticamente a los intentos de Bergson de "aprehender la 'vida' en una 'experiencia pura'", que lo hacen desembocar en "la espera profética de una 'intuición mística difusa' y de una "visión de más allá en una experiencia científica ampliada" (Agamben, 2011, p. 45).

123 Sobre algunas diferencias relevantes entre las concepciones de la memoria de Proust y de Bergson recomendamos consultar Melamed (2018).
} 
se han convertido los seres humanos anteriores, dejando vislumbrar destellos de un cierto posthumanismo que se prefigura en las ideas de Benjamin (Di Pego, 2017).

Y es que la experiencia, como Benjamin deja claro también en "Sobre algunos motivos en Baudelaire" al referirse a los lectores, "se ha modificado en su estructura [in ihrer Struktur verändert hat]" (2008c, p. 208; GS I 608). Ahora bien, y como se pregunta Oyarzún,

¿Es acaso un tipo de experiencia lo que la modernidad tecnológica arrasa, aquel que está vinculado al modo de producción artesanal? ¿O Benjamin sugiere que es la experiencia como tal la que sucumbe? Y si es así, ¿qué es lo que propiamente sucumbe con la destrucción de la experiencia? En fin, ¿a qué se llama experiencia aquí, cuál es su índice esencial? (2008, p. 8)

Exploraremos la primera de estas preguntas en el siguiente apartado, y la última de ellas en el próximo capítulo de esta investigación.

\section{3. ¿Imposibilidad o reconfiguración?}

En este punto, habiendo delineado el diagnóstico benjaminiano y su relación con la narración y la técnica, cabe preguntarse, en torno a la cuestión de la actualidad de la filosofía de Benjamin, si el empobrecimiento de la experiencia es un problema actual. ¿Es posible dar cuenta, desde la filosofía de Benjamin, de los cambios que afectan nuestro modo de relacionarnos con la tradición, con el pasado, con el entorno y en fin, con el mundo? Si nuestra capacidad de hacer o de tener experiencias se vio, como propone pensar Benjamin, afectada por los acontecimientos y los modos de comunicación que marcaron el siglo XX, lo que cabe preguntarse es si esta capacidad de experimentar puede verse modificada para albergar experiencias de un tipo nuevo o si hay que anunciar ya la muerte de toda experiencia. 
Entre los lectores actuales de Benjamin hay interpretaciones encontradas. En Infancia e historia, cuyo subtítulo programático es Ensayo sobre la destrucción de la experiencia, Agamben comienza su exposición de la siguiente manera:

En la actualidad, cualquier discurso sobre la experiencia debe partir de la constatación de que ya no es algo realizable. Pues así como fue privado de su biografía, al hombre contemporáneo se le ha expropiado su experiencia: más bien la incapacidad de tener y transmitir experiencias quizá sea uno de los pocos datos ciertos de que dispone sobre sí mismo. (2011, p. 7)

Agamben da cuenta, acto seguido, no solo de la pobreza de experiencias que sobrevino tras la gran guerra, a la que ya nos referimos, sino también de la dificultad de que la experiencia tenga lugar en el contexto de la gran ciudad,

pues la jornada del hombre contemporáneo ya casi no contiene nada que todavía pueda traducirse en experiencia (...). El hombre moderno vuelve a la noche a su casa extenuado por un fárrago de acontecimientos -divertidos o tediosos, insólitos o comunes, atroces o placenteros- sin que ninguno de ellos se haya convertido en experiencia. (Agamben, 2011, p. 8)

Basado, por un lado, en la relación entre experiencia y narración y, por el otro, en la importancia de la autoridad en la figura del narrador (ambas presentes, como vimos, en el análisis benjaminiano), Agamben concluye que, dado que "actualmente ya nadie parece disponer de autoridad suficiente para garantizar una experiencia" (2011, p. 9), la humanidad "ha perdido la experiencia" (2011, p. 10).

Ahora bien, y si bien la posición de Agamben puede parecer muy definitiva, alberga también algunas dudas, en parte porque, como sostiene García, su programa intelectual, si bien incluye una cierta "“recepción' de la obra benjaminiana” (2013, p. 6) se centra más bien en "una operación de actualización" (2013, p. 6), es decir, un intento de "movilizar ese trozo del 
pasado para iluminar zonas especialmente oscuras de nuestras problemáticas actuales" (2013, p. 6). Acerca del estado de la experiencia, Agamben sostendrá, por un lado, la existencia de experiencias en el presente, pero afirmará, por el otro, que "curiosamente el hombre se queda contemplándolas con alivio" (2011, p. 10). En lo que creemos que es una observación algo sesgada ${ }^{124}$, sostiene que "frente a las mayores maravillas de la tierra (por ejemplo, el Patio de los leones de la Alhambra), la aplastante mayoría de la humanidad se niega a adquirir una experiencia: prefiere que la experiencia sea capturada por la máquina de fotos" (2011, p. 10). Ahora bien, sería injusto no dar cuenta de que, tras reconocer el cadáver de la experiencia, el filósofo realiza dos movimientos interesantes: por un lado, se plantea como tarea, "recogiendo la herencia del programa benjaminiano 'de la filosofía venidera"' $(2011$, p. 10), preparar el lugar lógico donde "la semilla de hibernación de una experiencia futura" (2011, p. 10) pueda alcanzar su maduración; por el otro, atiende también que

en un momento en que se le quisiera imponer a una humanidad a la que de hecho le ha sido expropiada la experiencia una experiencia manipulada y guiada como en un laberinto para ratas, cuando la única experiencia posible es horror o mentira, el rechazo a la experiencia puede entonces constituir - provisoriamente- una defensa legítima. (2011, p. 12)

Y es que el pensador italiano reconoce que "quien se propusiera actualmente recuperar la experiencia tradicional se encontraría en una situación paradójica (...). El viejo sujeto de la experiencia de hecho ya no existe" (2011, p. 23). Dado este hecho, y en torno a si es posible una experiencia de tipo nuevo, se pregunta: “ ¿existe una experiencia muda, existe una in-fancia de la experiencia? Y si existe, ¿cuál es su relación con el lenguaje?” (2011, p. 47). Pero, como

\footnotetext{
${ }^{124}$ Por un lado, la observación de Agamben parece involucrar alguna medida de sesgo tecnófobo, en tanto interponer una cámara de fotos como parte de aquello con que miramos parece ser, ante sus ojos, casi una falta de respeto. Por otro lado, creemos que en la filosofía de Benjamin no hay elementos que permitan afirmar que algo es en sí una maravilla del mundo. Todo monumento, toda pieza de museo, todo edificio que podamos visitar, es una mezcla compleja documento de cultura y documento de barbarie.
} 
el siglo XX se encargó de señalar una y otra vez ${ }^{125}$, "la idea de una infancia como una 'sustancia psíquica' pre-subjetiva se revela (...) como un mito similar al de un sujeto pre-lingüístico" (Agamben, 2011, p. 64).

Agamben, finalmente, y si bien parece inclinarse por la negativa, no responde la pregunta por la posibilidad de la experiencia. En su lugar, abre de la mano de los muchos autores que incluye en su estudio -Hegel, Heidegger, Wittgenstein, entre otros- algunos interrogantes.

Por su parte, Didi-Huberman, en “Supervivencia de las luciérnagas”, critica la posición de Agamben y, al hacerlo, la simplifica un poco. Si bien, como reconoce también García en su lectura de este debate, Agamben fuerza a Benjamin, en su interpretación, "a formular una tesis no dialéctica, definitiva, a sancionar el fin y la «destrucción» de la experiencia allí donde en realidad se diagnosticaba un declive, una crisis, y se planteaba la pregunta por nuevas formas de experiencia" (2012a, p. 10), es importante tener en cuenta también los matices de la posición agambeniana, para no hacer con su texto lo mismo que se le acusa de hacer con los textos de Benjamin.

En discusión entonces con Agamben, Didi-Huberman propone pensar en cierta supervivencia de la experiencia, haciendo hincapié en el "vocabulario procesual" (2012a, p. 94) que despliega Benjamin para hablar de la narración ${ }^{126}$ y de la experiencia como tendiendo a perderse o marchando a su fin, en lugar de apresurarse a dar por muerto aquello que se debilita o, en todo caso, agoniza. Trabajando con la potencia de la debilidad, Didi-Huberman explora la supervivencia. En este sentido, frente a las luces cegadoras propias de "los reflectores de la

\footnotetext{
${ }^{125}$ Agamben mismo lo deja claro cuando plantea: "Solamente si pudiéramos encontrar un momento en que ya estuviese el hombre, pero todavía no hubiera lenguaje, podríamos decir que tenemos entre manos la 'experiencia pura y muda', una infancia humana e independiente del lenguaje. Pero tal concepción del origen del lenguaje es algo cuya fatuidad demostró la ciencia del lenguaje ya en la época de Humboldt" (2011, p. 65).

${ }^{126}$ Sobre el diagnóstico ligado a la narración, Di Pego (2015) sostiene que, en Benjamin, no se trata del fin de la narración sino de una cierta reconfiguración que habilita formas novedosas de narrar que tienen potencialidad crítica, como el teatro épico de Brecht.
} 
propaganda rodeando al dictador fascista" (2012a, p. 11), las luciérnagas que "erran débilmente" (2012a, p. 8) con su tenue luz intermitente le sirven para imaginar una cierta resistencia de lo amenazado. Frente a la gloria luminosa de los vencedores, reivindica a las luciérnagas que "tratan de escapar como pueden a la amenaza, a la condena que sacude ahora su existencia" (2012a, p. 12).

Evitando la "desesperación no dialéctica” (Didi-Huberman, 2012a, p. 51) que le cuestiona a Agamben, el autor se centra en volver a pensar la situación de la experiencia como una crisis en lugar de entenderla como una "falta radical, en la que toda transformación será pensada como destrucción" (2012a, p. 59). Frente a "las visiones apocalípticas" (2012a, p. 61) como la agambeniana, que "nos proponen el grandioso paisaje de una destrucción radical para que advenga la revelación de una verdad superior y no menos radical" (2012a, p. 61) y que juzga ligadas a una mirada metafísica de la historia, el autor se inclina por los "pequeños 'resplandores de verdad' -que son fatalmente provisionales, empíricos, intermitentes, frágiles, dispares, fugaces como luciérnagas-" (Didi-Huberman, 2012a, pp. 61-62).

En su lectura de Benjamin, quien textualmente escribe "die Erfahrung ist im Kurse gefallen", hace hincapié en que "el participio gefallen, 'caído', 'derrumbado', indica, ciertamente, un movimiento terrible. Pero sigue siendo un movimiento" (2012a, p. 94). En torno a la narración, al aura y a la experiencia, Benjamin muestra aquello que cae pero "no forzosamente desaparece" (2012a, p. 94), sino que sobrevive en la extrema precariedad. Y es justamente en el declive que se abre la posibilidad de la invención de una forma nueva.

Oyarzún no esquiva la pregunta. En el texto que acompaña a su traducción de $E l$ narrador sostiene, haciendo referencia al diagnóstico tal y como aparece en "Experiencia y pobreza", que

Benjamin no se limita a consignar una transformación de los modos en que se realiza la experiencia humana, debida a trastornos históricos de gran envergadura; 
pero tampoco habla, en sentido propio, de una conmoción meramente fáctica del contenido de verdad de la experiencia común y comunitaria. No; el factum histórico al que se refiere Benjamin lleva consigo un efecto trascendental: es la posibilidad misma de la experiencia la que queda puesta radicalmente en entredicho, en la medida en que aquellas transformaciones le sustraen las condiciones de verdad, participación, pertenencia e identidad que la determinan como tal. (2008, pp. 1112)

De esta lectura nos interesa destacar que, si bien da cuenta de la radicalidad del diagnóstico benjaminiano, no cae en una posición tan tajante como la que por momentos representa Agamben con respecto a la imposibilidad de la novedad. En su interpretación, no deja de tener en cuenta el tono nostálgico que caracteriza por momentos al texto de Benjamin, aunque se aleja de interpretar dicha nostalgia como un signo de derrota, atendiendo también a los momentos propositivos y hasta entusiastas del escrito.

En este marco de debates, encontramos a partir de la lectura de Jean-Louis Déotte una nueva forma de encarar el fenómeno, a partir de la introducción del concepto de "aparato" que, si bien es tomado de Benjamin, es reinterpretado más allá de él y puesto en diálogo con las consideraciones en torno a los dispositivos de Foucault, Deleuze y el mismo Agamben.

En La ciudad porosa. Walter Benjamin y la arquitectura, Déotte sostiene que puede rastrearse en Benjamin una filosofía de la técnica, influenciada por la lectura del historiador y teórico de la arquitectura moderna Sigfried Giedion. En efecto, Benjamin leyó parte del trabajo de Giedion y le escribió en 1929 una elogiosa carta en la que destaca: "Es usted capaz de esclarecer la tradición (die Tradition) a partir del presente (der Gegenwart), o más bien de hacer descubrir la primera a partir del segundo" (Déotte, 2013, p. 30). Nos interesa señalar aquí el vínculo que Benjamin establece entre el esclarecimiento de los modos tradicionales de vida y el presente, en tanto puede rastrearse extensamente en su propia obra como un cierto patrón. 
El punto de partida de la interpretación que Déotte desarrolla será “La obra de arte en la época de su reproductibilidad técnica". Allí, Benjamin plantea, como es sabido y mencionamos más arriba, que la percepción sensorial se ve modificada históricamente.

Integrando esta reflexión con los análisis más específicos sobre el cine presentes en el texto, Déotte propone pensar a estos medios que hacen posible la percepción como "aparatos". A partir de este concepto, propone entender las modificaciones de la percepción como modificaciones de los diferentes aparatos que hacen época. En su hipótesis, el aparecer mismo de los objetos requiere de un aparato que lo configure, lo que significa rechazar de plano toda posibilidad de que las cosas se nos den "desnudas" o despojadas a nuestra experiencia. Así, la experiencia, que es siempre experiencia de una época, es "experiencia de los efectos de un aparato dominante que habrá hecho época" (Déotte, 2013, p. 26) y está mediada por dicho aparato.

En "La obra de arte en la época de su reproductibilidad técnica” el término "Apparatur" aparece ligado al análisis de los medios técnicos que despliega el cine. Se analiza allí cómo el actor actúa para el aparato, en la medida en que este ocupa el lugar del público. La escena que resulta del montaje, a su vez, si bien se presenta al espectador como carente de aparatos, es en realidad el producto de los aparatos, inconcebible sin ellos. En palabras de Benjamin: "la presencia de la realidad en tanto que libre respecto del aparato [der apparatfreie Aspekt der Realität $]$ se ha vuelto aquí su presencia más artificial, y la visión de la realidad inmediata [der Anblick der unmittelbaren Wirklichkeit] una flor azul en el país de la técnica" ${ }^{127}$ (2015b, p. 55; GS I 458. Traducción levemente modificada).

Y es que, en la realidad de la reproductibilidad técnica, efectivamente, y como expone Benjamin en su trabajo sobre Baudelaire,

\footnotetext{
${ }^{127}$ La referencia benjaminiana a una "flor azul" ["blaue Blume"], está tomada de la novela Heinrich von Oflerding, de Novalis. La flor azul es asimismo un símbolo del romanticismo. Para más precisiones, ver Hansen (1987) y Hiebel (1951).
} 
la crisis de la reproducción artística que así se delinea puede representarse como parte integrante de una crisis dentro de la misma percepción [einer Krise in der Wahrnehmung selbst]. Lo que hace implacable al placer de lo bello es aquella imagen del mundo anterior [das Bild der Vorwelt] que Baudelaire consideró velada por las lágrimas que llora la añoranza (Benjamin, 2008c, p. 251; GS I 465).

En este contexto, el cine y su despliegue de aparatos técnicos adquieren el lugar de mediadores entre el público y aquello que éste visualiza. En efecto, Benjamin sostiene que el cine no sólo se caracteriza por "la manera en que el hombre se representa ante el sistema de aparato de filmación sino además por la manera en que, con ayuda de éste, se hace una representación del mundo circundante [die Umwelt sich darstellt]" (2015b, p. 58; GS I 461) y da cuenta de que el cine ha enriquecido nuestro mundo perceptivo.

Para comprender este rol que se le asigna al cine resulta muy esclarecedor recurrir a la analogía que Benjamin construye entre el psicoanálisis y el cine, que plantea que de la misma manera que la psicología de Freud ha hecho posible para el hombre percibir un lapsus, aislándolo y haciéndolo analizable, convirtiéndolo en algo existente mientras que antes pasaba inadvertido como un error banal, el cine "ha tenido como consecuencia una profundización parecida de la percepción en toda la amplitud del mundo de lo significativo" (2015b, p. 58) en la medida en que aparecen en él "conformaciones estructurales completamente nuevas" (2015b, p. 59).

La operación de Déotte consiste en tomar el concepto de aparato, que Benjamin emplea para hablar del cine, y convertirlo en la clave interpretativa para entender todo aquello que configure o haga posible la experiencia. De este modo, el concepto de "aparato" aparece ligado, en su análisis, a cuestiones que pueden parecer, a primera vista, de categorías muy diversas: la perspectiva, los pasajes, la pintura, la cámara oscura, el museo, la fotografía, el psicoanálisis y 
el cine. Tanto unos como otros configuran nuestra experiencia haciendo posible o imposibilitando la percepción de ciertos fenómenos.

En este marco, que proponemos entender como una ampliación del campo de aplicación del concepto de aparato por parte de Déotte, se inscribe también su comprensión de la narración, central para la problemática de la crisis de la experiencia, como un aparato. Esta aplicación del concepto de aparato también a las formas tradicionales de estructurar la experiencia resulta interesante, en la medida en que se propone hacer aquello que Benjamin valoraba en Giedion, esto es, "hacer descubrir la tradición a partir del presente" (Déotte, 2013, p. 30). El mismo Benjamin daría elementos para conceptualizar las formas tradicionales de la experiencia, como la narración, a partir de su estudio de las configuraciones técnicas que las hacen peligrar, como el cine.

La narración es caracterizada por Benjamin como el arte de intercambiar experiencias, de elaborar las vivencias en un relato que se transmite de boca en boca. En "El narrador" y como se expuso, Benjamin da cuenta de cómo la narración se constituye como el medio de la experiencia, en tanto allí se elaboran las vivencias y se tejen los sentidos compartidos intersubjetivamente. En este sentido, en la medida en que configura la experiencia haciendo comprensible o asimilable lo que sucede, la narración puede entenderse también como un “aparato" en el sentido que Déotte asigna al término, esto es, como configuración técnica del aparecer.

Como observa Benjamin, esta actividad artesanal en la que se elaboran las experiencias, propia de un determinado modo de vida, está llegando a su fin. Ahora bien, si pensamos, con Déotte, a la narración como un aparato histórico que configuró la experiencia y el aparecer de los objetos y los acontecimientos en una época determinada, es posible entender la crisis de la experiencia tal y como aparece en Benjamin como una crisis de la narración en tanto aparato que la configuraba. En este sentido, la crisis de la experiencia no equivaldría a su irremediable 
declive, sino que daría lugar a la posibilidad de su reconfiguración en la clave de nuevas experiencias configuradas por aparatos nuevos.

\section{4. ¿Una experiencia nueva?}

Aquí, todo lo técnico es sagrado: no hay nada que se tome más en serio que la técnica.

Walter Benjamin, 2015c, p. 94

En este contexto, y ante la opción nostálgica que lamenta que los modos de vida pasados estén acabados, cabe preguntarse cuáles serían, más específicamente, los aparatos capaces de albergar hoy una experiencia comunitariamente enriquecedora como la que Benjamin ve en crisis en el siglo XX. Nuestra hipótesis apunta, en esta búsqueda, a dos ámbitos muy visitados por el berlinés y que podemos pensar que laten también en la narración, en tanto es caracterizada como "el arte de contar historias" (Benjamin, 2010b, p. 172), a saber, por un lado, el arte y por otro la historia.

Si un aparato es, siguiendo a Déotte, aquello que configura el aparecer de las cosas ante nosotros, lo que permite que percibamos el mundo y que nos relacionemos con él, podemos pensar que tanto el arte como la escritura de la historia implican y ponen en marcha aparatos. El arte, como Benjamin deja claro, es capaz de modificar nuestra percepción y señalarnos objetos y aspectos del mundo que hasta el momento éramos incapaces de experimentar ${ }^{128}$. La fotografía y el cine serán, en este sentido, paradigmáticos. La historia, por su parte, nos plantea una relación con el pasado - en términos ya sea de glorificación, de continuidad, de ruptura, de

\footnotetext{
${ }^{128}$ En este sentido y como mencionamos en el capítulo 3, la influencia de Proust es evidente. Asimismo, el modo en que Simmel se detiene en las formas en que la pintura modifica y configura el aparecer de, por ejemplo, un paisaje, resulta clave.
} 
crítica, de salvación- que nos forma y estructura el modo en que percibimos los acontecimientos y los hacemos parte de nuestro presente.

En este contexto, resulta muy relevante el libro de Collingwood-Selby, El filo fotográfico de la historia. Walter Benjamin y el olvido de lo inolvidable. Allí, la autora entreteje la historia de la fotografía en el momento de su surgimiento con la de la historia misma como disciplina y, especialmente, con el historicismo, y encuentra interesantes conexiones, al punto de afirmar que "entre los postulados elementales del historicismo (...) y los del discurso predominante sobre la fotografía en el siglo XIX y XX existe un vínculo que podríamos llamar estructural, una básica y tenaz -aunque también secreta o inconsciente- complicidad” (2012, p. 5).

El punto de partida de Collingwood-Selby es el análisis del período en el que ambas disciplinas ingenuamente creen reflejar las cosas tal y como son, o tal y como han sido y, en este sentido, se comprometen con una noción específica de verdad: en efecto, la historia pretende diferenciarse del mito, la fábula o la ficción porque lo que narra realmente ocurrió y, en un sentido muy similar, la fotografía se distancia de la pintura por ser capaz finalmente de reflejar el mundo tal y como es, sin operar distorsiones. En este sentido, tanto la historiografía como la fotografía hacen jugar, para su autocomprensión, el dualismo entre el orden de los acontecimientos y el orden de su representación, y se entienden como posibilitando que la conexión entre ambos órdenes esté guiada por la fidelidad.

Collingwood-Selby entiende a la representación como uno de los pilares sobre los que se sostiene la soberanía del sujeto moderno cuya preeminencia se consolida con la filosofía de Descartes. En su filosofía, en palabras de la autora, "la representación ${ }^{129}(\ldots)$ se propone (...) como dispositivo fundamental de composición del mundo. El mundo es, necesariamente y

\footnotetext{
${ }^{129}$ Como veremos en el capítulo 6, el diagnóstico heideggeriano, fundamentalmente el que presenta en La época de la imagen del mundo, es en este contexto muy relevante.
} 
antes que nada, mundo representado" (2009, p. 40). En efecto, la matriz de la representación moldea la comprensión moderna de la relación del hombre con el mundo, a tal punto que, como denunciará Benjamin en "Sobre el programa de la filosofía venidera" ${ }^{30}$, la experiencia es reducida sólo a su aspecto cognoscitivo.

Otro rasgo que comparten la fotografía y la historia es que ambas creen tener el poder de capturar para siempre aquello que ya no es pero que debe ser conservado: en el caso de la historia, su consigna no es otra que "no olvidar lo que debe ser recordado" (Collingwood-Selby, 2012, p. 15).

Este rasgo, a diferencia de la supuesta neutralidad que caracterizaría a la fidelidad a la realidad que idealmente encarnan ambas disciplinas, da cuenta claramente del carácter eminentemente ético y político de estos registros de la realidad, y facilita las preguntas acerca de qué es lo que debe ser conservado o recordado, y qué o quién debe ser retratado. Según Baudelaire y como menciona Benjamin, "la fotografía (...) puede adueñarse sin obstáculo de todas esas cosas pasajeras que tienen el derecho 'a un sitio en los archivos de nuestra memoria"” (Benjamin, 2008c, p. 250). Asimismo, y al dar cuenta del inevitable recorte de la realidad que ambas disciplinas realizan para representarla, el carácter político de todo registro de la realidad abre una pregunta de gran importancia, a saber, ¿qué ocurre con aquello que queda por fuera del relato o fuera de la fotografía? Más aún, y más allá de la pregunta, más transparente, por aquello que fue sistemáticamente ocultado, resuena una pregunta más radical: ya que aceptamos que nuestro mundo perceptivo y nuestra experiencia están configuradas por aparatos, ¿qué sucede con aquello que ellos no son capaces de captar y que, en consecuencia, no somos capaces de percibir?

\footnotetext{
${ }^{130}$ En dicho texto y como veremos en el próximo capítulo, Benjamin critica la concepción kantiana de la experiencia, dando importantes indicios de qué concepto de experiencia encuentra fructífero para la filosofía, operando una ampliación del concepto que ha sido ya ampliamente reconocida (Fenves, 2011; Abadi, 2015).
} 
En este contexto cobra importancia la tradición como estructuradora de nuestra percepción y de nuestra experiencia. Nos enfrentamos con el hecho de que "lo radicalmente vencido sería aquello que inevitablemente se sustrae a la posibilidad de ser voluntaria y conscientemente percibido, identificado, representado, preservado e incorporado a la trama narrativa de la historia y del conocimiento" (Collingwood-Selby, 2012, p. 35). Resulta central preguntarse dónde puede habitar aquello que no fue narrado, ni fotografiado ni, en fin, percibido por nadie, o como lo formula Collingwood-Selby: “Cómo percibir en el pasado aquello que desde los hábitos de percepción del presente se ha vuelto imperceptible?” (2012, p. 35).

El historicismo deja que los valores y las formas de significar que han vencido, formando parte del presente y de los aparatos que configuran el modo en que el presente percibe y experimenta, impidan que el presente emprenda una tarea radical de crítica. El historiador que intenta vaciarse de valoraciones para ir a la historia a encontrarse con lo que realmente ocurrió, y que parece postular, en palabras de Benjamin, "una imagen 'eterna' del pasado" (2009, p. 249), es él mismo, en su modo de experimentar el mundo, al menos en parte, un producto de aquello que ha vencido en el pasado. Así,

lo que ha vencido es, en su momento más álgido, precisamente aquello que, con independencia de su voluntaria aceptación, y más allá de la posibilidad de ser cabal y conscientemente asumido, determina irrecusablemente la visión y valoración histórica de cada época y por tanto, la relación que el presente puede y quiere establecer con el pasado. (Collingwood-Selby, 2012, p. 31)

El propio Benjamin sostiene algo similar en "Parque central", como parte de su estudio sobre Baudelaire: "los conceptos de los que dominan han sido sin duda los espejos gracias a los cuales ha nacido la imagen de un 'orden' [das Bild einer 'Ordnung']. El caleidoscopio debe ser destruido" (2008c, p. 266; GS I 660). 
En este punto, es importante hacer hincapié en el problema teórico al que hemos arribado, ya que, por un lado, afirmamos que el mundo, y específicamente el pasado, no se da en sí mudo y desnudo, sino que se nos presenta mediado por aparatos, configurado por ellos. Así, lo que queda fuera del marco de los aparatos, aquello que no puede ser narrado, lo que queda en los márgenes del registro fotográfico o lo que no es contado por la historia encuentra dificultades para aparecer. Por otro lado, coincidimos con Benjamin acerca de la necesidad de emprender, desde la historia, la tarea de una crítica de la tradición y de los marcos que propone para nuestra experiencia. A su vez, y contrariamente al modelo contemplativo que propone el historicismo, y como se expuso en el capítulo 3, destacamos la importancia de hacer "una experiencia [Erfahrung] con ese pasado, que es única" (Benjamin, 2009, p. 249), rescatando en él aquello que ha sido vencido. Sin embargo, no queda claro cómo sería posible hacer una experiencia con aquello que, por haber sido vencido, no encuentra lugar en la representación y no logra ser percibido por nosotros desde el presente.

Frente a este problema, y ante la tentación de afirmar ingenuamente que el pasado está ahí para que el historiador vaya a buscar unos hechos u otros para contar (eligiendo entre los acontecimientos que narrarían la historia de los vencidos y aquellos que contarían la historia de los vencedores), Collingwood-Selby encuentra, con Benjamin, una salida: aquello que no encuentra lugar en la historia como representación, y que tampoco existe en sí -pues “el pasado no puede ni podrá nunca manifestarse en la historia en y por sí mismo" (Collingwood-Selby, 2012, p. 47)-, se hace presente aún "como huella, como marca, como traza de su desaparición" (Collingwood-Selby, 2012, p. 47).

Sobre la huella, en la Obra de los pasajes dice Benjamin, haciendo un paralelismo con la definición de aura y distanciando ambos conceptos: "La huella viene a ser aparición de una determinada cercanía, por más lejos que ahora pueda estar eso que la ha dejado a sus espaldas" (2013, p. 719). Aquello que fue vencido, que no forma parte de la historia oficial y que no se 
ve representado en monumentos ni en documentos, deja una huella de su existencia que lo sobrevive en el presente.

Lo crucial de la propuesta de Collingwood-Selby es que, con Benjamin, deja de pensar a la representación como única inscripción posible de un acontecimiento, y se centra en los restos o los márgenes de esa representación. Para esto, y como deja claro Benjamin en su trabajo sobre Baudelaire, la pista está tanto en la teoría de Freud ${ }^{131}$ como en Proust: para el primero, la huella de un acontecimiento en el inconsciente es más fuerte y más poderosa que la representación de un acontecimiento pasado que el sujeto registra conscientemente, en tanto estas inscripciones inconscientes tienen el poder de irrumpir en la vida psíquica. El concepto de huella aparece ya aquí en tanto, para Freud, "devenir consciente y dejar una huella en la memoria son incompatibles totalmente para el mismo sistema" (Freud, citado por Benjamin, 2008c, p. 214). Para el segundo, que compone el relato de su infancia a partir de una cierta investigación de las huellas en la que interviene siempre el azar, "sólo puede convertirse en componente de la mémoire involontaire lo que no ha sido 'vivenciado' con conciencia y explícitamente, es decir, aquello que al sujeto no le sucedió como 'vivencia' [was dem Subjekt nicht als 'Erlebnis' widerfahren ist]” (Benjamin, 2008c, p. 214; GS I 613). Volveremos sobre esta reelaboración benjaminiana de Freud y Proust en el próximo capítulo, en tanto resulta central para la conformación del concepto de experiencia de Benjamin.

Volviendo a la importancia de la huella como posible inscripción, y si bien no nos detendremos en ella, resulta interesante la discusión que se plantea en torno a aquello que no se inscribe en absoluto, esto es, que no sólo no es representado sino que tampoco deja tras de sí una huella de su existencia ${ }^{132}$. Creemos, con Collingwood-Selby, que difícilmente pueda

\footnotetext{
${ }^{131}$ Benjamin se refiere aquí al ensayo Más allá del principio de placer, de 1921.

${ }^{132}$ Para ilustrar este punto, Collingwood-Selby utiliza un ejemplo que toma de Déotte, acerca de un huracán que con su fuerza arrasa con una estación de control meteorológico destruyendo los instrumentos de medición. "¿Qué ocurriría, sin embargo, con un acontecimiento no inscriptible, irrepetible, como estos huracanes que dejan pasmados a los instrumentos de control meteorológicos? ¿Acaso el físico podría sostener razonablemente que, después del terremoto, nada ha tenido lugar si nada ha sido inscrito en sus aparatos, cuando todo a su alrededor
} 
pensarse en un acontecimiento privado totalmente de inscripción, aun cuando, con Benjamin, podamos pensar que su huella encontrará “el ahora de la cognoscibilidad” (Benjamin, 2013, p. 744) en otro momento. Con respecto a los acontecimientos no registrados por la historia, la autora se pregunta:

¿se trata aquí realmente de acontecimientos que han sido completa $y$ definitivamente privados de cualquier forma y superficie de inscripción, o más bien de acontecimientos cuyas formas y superficies de inscripción permanecen, más allá o más acá de su voluntaria manipulación, todavía ilegibles e irreconocibles para un presente cuya percepción, cuya receptividad, han sido técnica, política, cultural e institucionalmente adiestradas? (Collingwood-Selby, 2012, p. 54)

Es este modo de comprender la inscripción de los acontecimientos el que, creemos, permite abrir un camino para hacer de la historia un ámbito capaz de estructurar una experiencia enriquecedora que pueda, no ya restituir los sentidos perdidos tras la crisis de la experiencia y la ruptura de la tradición que esta significa, sino encontrar sentidos nuevos en la experiencia misma de la ruptura y de la interrupción. Frente al historicismo, la contemplación y la representación del pasado, Benjamin propone su actualización, que "desarticula toda relación contemplativa y estetizante" (Collingwood-Selby, 2012, p. 131).

Así como es posible identificar dos modos de comprender la historia, y de hacer historia, radicalmente diferentes, que posibilitan dos maneras diferentes de relacionarse con el pasado, así también es posible, de la mano de Benjamin, encontrar en la fotografía esta doble cara, en tanto, entendida como aparato, abre un abanico de posibilidades en lo que respecta a la relación del hombre con su entorno: en la capacidad de la fotografía de modificar nuestra percepción habita una potencialidad transformadora capaz de enriquecer nuestra experiencia.

no es más que ruina y devastación?” (citado por Collingwood-Selby, 2012, p. 50). La autora se pregunta: “¿No son acaso los aparatos destruidos y en ruinas un modo de inscripción, una huella, una marca de la catástrofe?" (p. 52). 
Como mencionamos, la fotografía, en el momento de su surgimiento, que podemos caracterizar con Dubois como el momento del "discurso de la mímesis" (citado por Collingwood-Selby, 2012, p. 181), se pensó como “espejo de lo real”, coincidiendo así con algunos de los postulados del historicismo. Tanto es así que esta nueva tecnología, comprendida como capaz de reproducir fielmente la realidad, fue convertida por el historicismo en una herramienta suya, en tanto

hasta la invención de la fotografía, ningún medio de registro -visual o escrito- de la realidad había logrado erradicar hasta tal punto la intervención de la mano, de la voluntad, del pensamiento, de las pasiones e inclinaciones humanas del proceso de su producción. (Collingwood-Selby, 2012, p. 97) ${ }^{133}$

Como expone la autora, la reproducción fotográfica presenta, en relación a las tecnologías disponibles en el momento, tres novedades, que se acercan al ideal mismo de la reproducción, a saber, mecanicismo, exactitud e instantaneidad. Con el primero, quedaría garantizada la neutralidad, dado el borramiento de la subjetividad que estaría implicado en la eliminación del carácter artesanal del proceso de reproducción; mientras que con la exactitud y la instantaneidad se lograría acortar la distancia, temporal pero también cualitativa, que tradicionalmente se imponía entre el original y su reproducción ${ }^{134}$. Así, "la empatía como método encuentra en la fotografía como procedimiento mecánico la lúcida y tangible evidencia de su posibilidad: la posibilidad de un conocimiento totalmente objetivo de la realidad" (Collingwood Selby, 2012, p. 98). Esta objetividad es postulada a un punto tal que varios

\footnotetext{
133 'Dicho muy escuetamente, el novedoso mecanismo fotográfico de inscripción, de registro y de 'reproducción' de la realidad visible, tal como fue entendido por los discursos predominantes del siglo XIX y sus herederos del siglo XX, habría proporcionado -bajo cuerda- a la razón historicista, un modelo muchísimo más adecuado que el de la escritura, a partir del cual pensar y postular el tipo de relación que el presente historiador podía y debía, según dicha razón, establecer con el pasado" (Collingwood Selby, 2012, p. 86).

${ }^{134}$ María Gainza escribe, en torno a esta distancia cualitativa: "La gente no se cansa de decir: hasta que no ves un Rothko en vivo no ves ni la mitad. A mí me sorprende todo lo que se puede ver en una reproducción" (2017, p. 149).
} 
pensadores entienden a las fotografías como resultado de la posibilidad que la cámara le otorga a la naturaleza de registrarse a sí misma: "la fotografía se revelaba como la lengua y el arte de la propia realidad" (Collingwood Selby, 2012, p. 102).

Ahora bien, así que como la comprensión benjaminiana de la tarea de la historia se aleja radicalmente de la razón historicista, de su concepción del tiempo y de la forma en que conceptualiza el pasado, también en el caso de la fotografía Benjamin otorga herramientas para pensarla, no ya como un medio de registro neutral de la realidad, sino como un aparato capaz de modificar nuestra percepción y con ella nuestra experiencia.

Además de la potencialidad de la reproductibilidad técnica como portadora de la masificación del arte, también habita en las nuevas manifestaciones artísticas la posibilidad de una restitución de la experiencia, aun cuando implica siempre su transmutación. Lo resume muy atinadamente Buck Morss cuando sostiene que "la reproducción tecnológica restituye a la humanidad aquella capacidad de experiencia que la producción tecnológica amenaza arrebatarle" (1995, p. 295). En efecto, y si bien los avances técnicos y la aceleración de la vida en las ciudades aparecen como causantes de la crisis de la experiencia, esta experiencia en crisis puede encontrar en las nuevas posibilidades técnicas medios que, si bien no la restituyen en sus modos tradicionales, le permiten operar una reconfiguración. Volviendo a la terminología de Déotte, con el surgimiento de nuevos aparatos, la percepción y la experiencia se ven modificadas, en tanto son estructuradas por medios nuevos.

En este contexto, la fotografía resulta central, en tanto la cámara le permite a la visión humana centrarse en aquellos detalles que no se logran alcanzar con el ojo desnudo. En palabras de Benjamin:

Ella puede, por ejemplo, resaltar en la fotografía aspectos del original que son asequibles a la lente, con su capacidad de elegir arbitrariamente un punto de vista, y que no lo son al ojo humano; puede igualmente, con ayuda de ciertos 
procedimientos, como la ampliación o el uso del retardador, atrapar imágenes que escapan completamente a la óptica natural [die sich der natürlichen Optik schlechtweg entziehen]. (Benjamin, 2015b, p. 29; GS I 476)

En la medida en que "la naturaleza que habla a la cámara no es la misma que habla al ojo" (2015b, p. 48) aparecen en las fotografías "formaciones estructurales del todo nuevas" (2015b, p. 48). Asimismo, tanto la fotografía como el cine son capaces de mostrarnos escenas con las que estamos familiarizados, pero con respecto a las cuales no tomamos distancia crítica, así como es capaz de hacernos notar movimientos que en la cotidianidad no logramos percibir. En este sentido, y si bien está lejos de celebrar alegremente todo avance técnico, Benjamin se aleja también de la posición conservadora que clama por la restitución de la experiencia estética tradicional. Esto lo deja claro en "Pequeña historia de la fotografía", de 1931, donde, como analizamos en el capítulo 3, se aleja decididamente del concepto fetichista del arte, que impide vislumbrar las potencialidades transformadoras de los nuevos medios artísticos que, lejos de ayudar al hombre a plasmar, finalmente, el mundo tal y como es, le muestran un mundo antes desconocido y le ofrecen nuevos modos de experimentar y registrar la realidad.

Tanto como en la historia, en el ámbito del arte la experiencia enriquecedora que Benjamin vislumbra es una experiencia con potencialidad política, en tanto, por un lado, el fin del arte aurático y el acercamiento de la obra a las masas "conducen a un enorme trastorno del contenido de la tradición [einer gewaltigen Erschütterung des Tradierten] -un trastorno de la tradición que es la otra cara de la crisis y renovación contemporáneas de la humanidad [die Kehrseite der gegenwärtigen Krise und Erneuerung der Menschheit]" (Benjamin, 2015b, p. 30; GS I 477) y, por otro lado, la fotografía es capaz de hacernos configurar lo que percibimos de un modo nuevo, distanciarnos de la mirada que naturaliza lo dado y elaborar nuestra experiencia en un sentido crítico. 


\subsection{Consideraciones finales}

Tanto en el marco de la crisis de la experiencia como en el de la estetización de la política o del pasado es característica la incapacidad de dar respuesta. En efecto, la insensibilización, como producto del shock y como reacción ante la ruptura de la tradición, tiene un efecto despolitizador. En el fascismo y como explica Galende, "la progresiva anestesización de la vida humana ya no se limita sólo al plan jurídico de retrotraer esa vida al umbral de su mera condición biológica: ahora la torna indolora e insensible a su propia aniquilación" (2009, p. 176). La estetización de la vida que atendimos en la primera sección de esta investigación es así el punto más peligroso del empobrecimiento de la capacidad de experimentar, en tanto obtura las posibilidades de transformación. La recuperación de alguna forma de experiencia se convierte, así, en una necesidad: por eso Benjamin indica como tareas tanto hacer una experiencia con el pasado como politizar el arte.

En alguna medida, y como adelantamos, la crisis de la experiencia preanuncia el problema de la estetización sin nombrarlo aún: el mundo se nos aparece meramente como algo colocado en frente, y la implicación con el entorno se hace difícil de tramitar sin los marcos de la tradición informando nuestro accionar y nuestra percepción.

En la interpretación de Galende, la puesta en marcha fascista de mecanismos estetizantes y de la técnica al servicio de la destrucción encuentra también continuidades con el contexto que la precede. En sus palabras: "lo que a Benjamin le interesa, más bien, es mostrar que fascismo es el nombre para la gestión más brutal de algo que ya se encuentra dispuesto en el hombre" (Galende, 2009, p. 179). Eso que ya está dispuesto es lo que, ya en 1933, Benjamin encuentra en la crisis general de la experiencia y, varios años antes, delinea como problema a partir de su crítica al concepto kantiano de experiencia. 
Ahora bien, y como intentamos mostrar en este capítulo, es posible encontrar, en algunas lecturas actuales de Benjamin, como las de Agamben, Didi-Huberman, Déotte y Collingwood-Selby, las herramientas para apoyar la lectura de dicha crisis como una reconfiguración. En este sentido, nos interesa rescatar un fragmento que desliza Benjamin en el convoluto M de la Obra de los pasajes:

Hoy se están intentando dominar las nuevas experiencias ciudadanas [die neuen Erfahrungen von der Stadt] recurriendo a incluirlas en el marco de lo que son las viejas y heredadas experiencias de la naturaleza, aplicando para ello los esquemas de los mares y el bosque primitivo. (2013, p. 719; GS V 560)

Creemos que en su propuesta late la posibilidad de aprovechar la pobreza de experiencias para alojar y explorar las experiencias que nuestro tiempo histórico hace posibles. En efecto, si pensamos la crisis como crisis del aparato y no ya de la experiencia en sí misma -en tanto no hay algo así como una experiencia despojada de aparatos- ${ }^{135}$, y si entendemos a su vez la crisis como un proceso que, en su marcha, motiva reacciones valiosas, algo de la experiencia encontraría una salvación. Aun así, y si la experiencia es tal en tanto está configurada por un aparato, entonces debemos aceptar que la experiencia que los nuevos aparatos hacen posible no es aquella cuya pérdida se constata sino otra distinta. En este sentido, la condición para no sucumbir a un lamento por la imposibilidad actual de la experiencia será, por un lado, el abandono de ciertos presupuestos metafísicos que buscan eternidad en aquello que no es más que un constructo histórico y, por otro, la redefinición de lo que la experiencia misma sea. Es allí donde se encuentra, creemos, la mayor actualidad de la filosofía de Benjamin, por lo que en el próximo capítulo nos centraremos en esta redefinición.

\footnotetext{
${ }^{135}$ Cabot (2008) también propone pensar en el diagnóstico benjaminiano como la constatación de "una crisis de una forma (particular) de construcción y transmisión de la experiencia” (p. 61).
} 


\section{Capítulo 5}

\section{Redefinir la experiencia}

Mientras tanto, todo lo que sucede, sucede en su reverso. Una batalla sobre lo sensible en la que se juega su suerte: la de conquistar su nuevo concepto.

Diego Sztulwark, 2019, p. 184

\subsection{Introducción}

Como mencionamos en la introducción a esta sección, el concepto de experiencia se asocia, en algunas lecturas, de manera simplista al proyecto filosófico de la modernidad. En efecto, es un hecho que el motivo adquiere centralidad en los planteos de Bacon, Locke, Hume y Kant. Aun así, cabe destacar que, si bien en la modernidad la filosofía trabajó en la delimitación de un concepto de experiencia, de la misma manera puede decirse que trabajó en pos de dejar atrás otros conceptos de experiencia posibles. La ciencia moderna, y paradigmáticamente la revolución copernicana en el ámbito de la astronomía, puso en marcha un proceso de refutación de la experiencia ligada al sentido común: aquella que, en el ámbito filosófico, se corresponde con la que se expone en el ensayo "De la experiencia" de Montaigne (2003). Este modo de articular la experiencia, que "discurre disgresivamente combinando anécdotas y aperçus con argumentos y citas, retomando temas y enfocándolos desde diferentes ángulos" (Jay, 2009, p. 39), es rechazado en su forma y su contenido por quienes "querían salir al mundo e investigarlo con la esperanza de hallar un conocimiento nuevo y fiable, un 
conocimiento que les permitiera dominar lo que hasta entonces había estado fuera del control humano" (Jay, 2009, p. 42) ${ }^{136}$.

Más allá de que tomemos el ejemplo de Montaigne o cualquier otro, lo que es claro es que la experiencia que se identifica con el proyecto moderno -que es, a su vez, en alguna medida, una construcción teórica posterior a los planteos filosóficos que supone englobar- es una forma específica de experiencia (o más de una). Asumiendo este hecho, se abre la posibilidad de rechazar algunos aspectos del proyecto filosófico moderno o, más específicamente, criticar por ejemplo la teoría del conocimiento kantiana y el marco metafísico que la sustenta, sin necesidad de abandonar en el camino el concepto de experiencia, como propusieron, según vimos, Rorty y Lyotard.

En este sentido, compartimos la afirmación de Scott en torno a que, en lugar de abandonar la referencia a la experiencia, “dada la ubicuidad del término, (...) sería más útil trabajar con él, analizar sus operaciones y redefinir sus significados" (Scott, citada por Jay, 2009, p. 17). En efecto, es exactamente eso lo que realizó Benjamin, en tanto "tuvo que despojar al término de su connotación negativa a fin de aplicarlo a sus propósitos más radicales" (Jay, 2009, p. 35) ${ }^{137}$.

En este contexto, en el presente capítulo intentaremos mostrar que, en la filosofía de Benjamin, el concepto de experiencia es sometido a una serie de modificaciones que le permiten operar de un modo novedoso que lo habilita, no sólo a articular una manera actual de comprender la relación del hombre con el mundo, sino también a asumir una tradición y trabajar con ella en lugar de evadirla. Como Benjamin sostiene en la Tesis VI de "Sobre el concepto de

\footnotetext{
${ }^{136}$ Jay se refiere a su vez al desinterés en la experiencia religiosa que dominó las reflexiones en la Edad Media y buena parte de la modernidad: "El escolasticismo estaba más interesado en demostrar la existencia de Dios mediante argumentos racionales que en investigar la experiencia religiosa del creyente" (Jay, 2009, p. 33). Aun así, destaca como "excepción a este desprecio general por la experiencia, al menos en una de sus variedades" a "la obra de San Agustín, cuyas reflexiones confesionales sobre su viaje espiritual han constituido frecuentemente el punto de partida de las ulteriores elaboraciones de la "experiencia interior"' (p. 34).

${ }_{137}$ Jay se refiere aquí específicamente al texto Erfahrung que escribe Benjamin en 1913 y al que volveremos más adelante. Aun así, sus palabras alcanzan, creemos, a gran parte de su producción.
} 
historia", "en cada época hay que esforzarse por arrancar de nuevo la tradición al conformismo que pretende avasallarla [die Überlieferung von neuem dem Konformismus abzugewinnen" (Benjamin, 2009, p. 113; GS I 695).

A su vez, y si bien la filosofía benjaminiana no se abre tanto a través de conceptos como de imágenes e intervenciones puntuales (Adorno, 2001, p. 29; Weidner, 2019, pp. 177-178) ${ }^{138}$, el motivo de la experiencia es capaz de ofrecer una forma de transitar por los diferentes momentos y preocupaciones que recorren su obra, desde los inicios mismos de sus reflexiones en el marco de su militancia en el Movimiento Juvenil [Jugendbewegung] que lideraba Gustav Wyneken hasta sus últimos días de trabajo en las Tesis "Sobre el concepto de historia" y en su monumental e inconclusa Obra de los pasajes.

Lejos de limitarse al diagnóstico que atendimos en el capítulo 4, la experiencia recorre en efecto toda la producción del berlinés, dando cuenta no tanto de la continuidad de una concepción o de una idea específica de experiencia, sino más bien de la permanencia de una pregunta, o de una preocupación, por el estado y el estatus de la experiencia en su tiempo. Compartimos en este sentido parcialmente la idea de Peter Krumme que recupera Uwe Steiner, a saber, que "el pensamiento filosófico de Benjamin está centrado en una teoría de la experiencia, sobre la cual se ha llamado la atención ya tempranamente como 'el centro de ningún modo oculto' de todas sus concepciones" (Steiner, 2014, p. 243. Las cursivas son nuestras). La experiencia es sin dudas uno de los motivos benjaminianos más relevantes y más usuales (Simonis, 1996), pero lo que Benjamin trama en torno a este concepto no es pasible de ser abordado como una teoría acabada que opera como centro de sus concepciones, sino más bien como una multiplicidad de abordajes que señalan a este concepto como un punto muy conectado del entramado complejo que es su producción, carente estrictamente de centro.

${ }^{138}$ Nos centraremos en este aspecto de la filosofía de Benjamin en el capítulo 7 de esta investigación. 
Asimismo, y dado que no es posible encontrar en Benjamin propiamente un sistema, no tendría sentido intentar una definición estática de la cual derivar aplicaciones prácticas. Será mejor proceder mediante una aproximación $-\mathrm{o}$ un rodeo- que haga justicia a las curvas y las tensiones propias de la obra del autor. En este sentido, será necesario trabajar conjuntamente con dos hechos: por un lado, que, como sostiene Déotte, Benjamin fue efectivamente un "pensador de las grandes formas de la experiencia" (2013, p. 53); por el otro, que, como expresan Opitz y Wizisla, en Benjamin los conceptos “no tienen nada de estático, experimentan cambios de significado" (2014, p. 10) y que, por eso, hablar de "“el concepto benjaminiano de experiencia' (...) se revela problemático" $(2014$, p. 11).

Si bien sostenemos que es en la problematización de su crisis y en la puesta en duda de su posibilidad, en la década del 30, donde se encuentra el momento de mayor potencia para delinear la concepción de la experiencia de Benjamin, y por eso volveremos sobre algunos textos claves de esta constelación, también resultan muy relevantes escritos que abordan otras problemáticas, así como algunos ensayos y artículos tempranos, especialmente "Sobre el programa de la filosofía venidera" [Über das Programm der kommenden Philosophie], de 1918, y “Destino y carácter” [Schicksal und Charakter], de 1921, que dan cuenta de aspectos específicos de la crítica benjaminiana del concepto de experiencia heredado de la tradición filosófica.

En esta reconstrucción, no obstante, en lugar de guiarnos cronológicamente, preferimos trazar los contornos de la redefinición de la experiencia en torno a ejes. Aun así, es importante reconocer algunas líneas en el desarrollo del concepto. En palabras de Jay:

Benjamin pudo enriquecer su concepto de experiencia trascendiendo el ámbito de las similitudes miméticas y de la doctrina religiosa para incluir complicadas exploraciones de la temporalidad, la narrativa, la memoria, la tradición, la destrucción, la tecnología, la cultura de masas y la distinción categórica entre las dos versiones de experiencia: la Erlebnis y la Erfahrung. Como resultado de ello 
sus reflexiones cobraron una textura política e histórica notoriamente ausente en sus primeros trabajos. (Jay, 2009, p. 379)

Si bien coincidimos en general con la idea que se expresa aquí, creemos a su vez que es posible operar cruces entre diferentes momentos de la producción de Benjamin, en tanto algunos motivos tempranos vuelven a aparecer tardíamente, reivindicando quizá para sí la textura política que Jay les niega. En este sentido se pronuncia Hansen, cuando se refiere a la forma en que Benjamin transforma algunos impulsos teóricos de su juventud en "su esfuerzo por reimaginar (algo como) la experiencia bajo las condiciones de la cultura mediada por la tecnología” (Hansen, 2007, p. 339).

En torno a la periodización de las ideas de Benjamin, y sin negar la productividad de los trabajos que la abordan, es importante tener presentes las observaciones de Wohlfarth (2015), quien cuestiona ciertas narrativas que trazan períodos definidos en su producción, y afirma que

al menos desde finales de los años veinte en adelante, los escritos de Benjamin constituyen una serie ininterrumpida de pequeñas improvisaciones, estrategias pensadas para apaciguar la desesperación, medidas preventivas y antídotos calculados para lidiar con situaciones en las que todo puede salir mal. (2015, p. 137)

Dimópulos, a su vez, si bien reconoce devenires en la producción benjaminiana, se opone a aquellos que encuentran allí rupturas que dejan lo pasado atrás y prefiere pensar en capas geológicas que subsisten como sustratos: la del movimiento juvenil, la de la teología, la de la sensibilidad surrealista y una última -urgente-marxista (2017, p. 189). La autora sostiene que, a través de esas capas, ocurren también mutaciones en torno a ciertas ideas núcleo que reaparecen modificadas, reconvertidas en torno a conceptos nuevos, en contextos diferentes, en constelaciones antes impensadas y sostiene: "si se quisiera, se podrían postular devenires y progresos. No así superaciones ni abandonos” (Dimópulos, 2017, p. 189). En efecto, forzar a 
la producción de Benjamin a desarrollarse recorriendo una línea progresiva implicaría un olvido del peso que tiene en su obra la crítica a la ideología del progreso, que para nada se limita a la historiografía.

En este capítulo analizaremos entonces cómo la idea benjaminiana de experiencia abandona uno a uno los anclajes tradicionales, operando corrimientos significativos en función de dar respuesta a diferentes problemas. Así, el concepto se corre de la vivencia en la pasividad a la experiencia como una elaboración en la que son innegables el rol de la tradición y la importancia del lenguaje; a su vez, el sujeto de la experiencia se resignifica en lo colectivo, y la experiencia del mundo se reconfigura en una experiencia con y en un mundo de objetos, tiempos y espacios que no son ya ni tan externos, ni tan mudos.

Intentaremos mostrar, con este mapa de desplazamientos, los alcances y la potencialidad de una rehabilitación contemporánea de la idea de experiencia ${ }^{139}$. Con este fin, comenzaremos en el próximo apartado explorando la diferencia entre los conceptos de vivencia [Erlebnis] y experiencia [Erfahrung], luego de lo cual reconstruiremos las observaciones de Benjamin sobre las formas mecanizadas del trabajo y el juego, en tanto este análisis resulta central para esclarecer de un modo más preciso dicha diferencia.

\subsection{De la vivencia a la experiencia}

El primer dato que hay que tener en cuenta para delimitar el concepto de experiencia de Benjamin es la distinción, ya ampliamente explorada, entre las ideas de Erlebnis $^{140}$ [vivencia o experiencia vivida] y Erfahrung [experiencia], como dos posibles sentidos de experiencia.

\footnotetext{
${ }^{139}$ La recuperación del concepto benjaminiano de experiencia fue defendida, entre otros, por Elsaesser (2009). En su caso, propone introducir la idea benjaminiana de experiencia en los debates actuales sobre cine, y ponerla en diálogo con los desarrollos de la teoría de las emociones, los estudios culturales y el psicoanálisis.

${ }^{140}$ Como apunta Weber (2014), Erlebnis es el término que elige Dilthey para la experiencia auténtica. No se trata de un detalle menor, dado que la polémica con Dilthey es importante para el desarrollo de la filosofía de Benjamin, especialmente para su filosofía de la historia.
} 
Jay da cuenta de esta diferencia terminológica haciendo hincapié en los equivalentes en inglés, ya que tanto Erfahrung como Erlebnis se vuelcan por lo general como experience. En ese contexto, y comenzando por el concepto de Erlebnis, explica que:

contiene la raíz de la palabra Leben (vida) y a veces se traduce como experiencia vivida $^{141}$ ["vivencia" en castellano]. Aunque erleben es un verbo transitivo e indica la experiencia de algo, Erlebnis suele implicar una unidad primitiva, previa a cualquier diferenciación u objetivación. Normalmente localizada en el "mundo cotidiano" (el Lebenswelt) del lugar común y de las prácticas no teorizadas, puede sugerir, asimismo, una intensa y vital ruptura en la trama de la rutina cotidiana. Pese a que Leben indica también la totalidad de una vida, Erlebnis generalmente connota una variante de la experiencia más inmediata, prerreflexiva y personal que Erfahrung. (2009, p. 27)

Si bien parte de lo que aquí explica Jay resulta útil para comprender la distinción que traza Benjamin, y como veremos al analizar sus escritos, el eje de la "vida cotidiana" tal y como atraviesa la distinción terminológica que aporta la etimología de los conceptos y su uso habitual no resulta del todo productivo para el caso específico de Benjamin. Su filosofía se caracteriza -como la de Simmel- por otorgar dignidad filosófica a los más diversos fenómenos de la vida cotidiana, como puede observarse en sus textos acerca del juego infantil o de diversas comidas y ciudades, o en su recuperación, por ejemplo, de recuerdos infantiles y de fábulas para pensar problemas complejos.

Acerca de la Erfahrung, y luego de mencionar el caso de Kant y el kantismo, en cuya tradición Erfahrung se refiere a los juicios cognitivos acerca de las impresiones sensoriales (Jay, 2009, p. 27), expone Jay que

${ }^{141}$ En inglés, la forma a la que se refiere Jay es "lived experience". 
también ha llegado a significar una noción de experiencia temporalmente más amplia, basada en un proceso de aprendizaje, en la integración de momentos discretos de la experiencia en un todo narrativo o en una aventura. Esta última visión, llamada en ocasiones una noción dialéctica de la experiencia, connota un movimiento progresivo, no siempre sin asperezas, a lo largo del tiempo, implicado por el Fahrt (viaje) insertado en Erfahrung, y por la conexión con la palabra "peligro" (Gefahr). (2009, p. 27)

De nuevo, si bien en alguna medida la definición hace justicia a la que atraviesa la filosofía de Benjamin, la progresión que se indica como parte de la experiencia debería ser matizada para dar cuenta de la especificidad de la concepción del tiempo del autor. Si bien Jay aclara que la progresión puede atravesar asperezas, la salvedad no alcanza a dar cuenta de que, en el marco de la filosofía de la historia de Benjamin y como vimos en el capítulo 3, la experiencia puede estar ligada tanto a rodeos que esquivan el camino recto como a a saltos temporales abruptos y a encuentros inesperados con el pasado.

Delimitadas entonces, en sentido general, las formas de funcionamientos de los conceptos de Erlebnis y Erfahrung, y realizadas algunas aclaraciones, seguiremos explorando esta distinción de la mano de los textos del propio Benjamin.

En su obra, este binomio terminológico es delineado especialmente en "Sobre algunos motivos en Baudelaire" y en algunos convolutos de la Obra de los pasajes. En el primero de estos textos, Benjamin comienza realizando una crítica a la filosofía de la vida. Partiendo del hecho, que se expresa en los nuevos hábitos de lectura, de que la experiencia del lector se ha modificado de modo estructural (2008c, p. 208) $)^{142}$, repudia que cuando "se interroga a la filosofía" (2008c, p. 208),

\footnotetext{
${ }^{142}$ Volveremos sobre la experiencia de la lectura y la importancia de repensar los formatos literarios y los soportes de la lectura en el capítulo 7 de esta investigación.
} 
se encuentra uno con un hecho peculiar. Desde los finales del siglo pasado, ésta ha realizado una serie de intentos por apoderarse de la experiencia 'verdadera' [der 'wahren' Erfahrung], en contraposición a esa experiencia que se sedimenta en la existencia, normalizada y desnaturalizada, de las masas ya civilizadas [einer Erfahrung (...), welche sich im genormten, denaturierten Dasein der zivilisierten Massen niederschlägt]. Unos tanteos que suelen encuadrarse bajo el concepto de filosofía de la vida [Lebensphilosophie]. Como es comprensible fácilmente, tales tanteos nunca habían partido de la existencia del hombre en sociedad. (2008c, p. 208. El enfatizado es nuestro; GS I 608)

Benjamin se refiere en este pasaje a Dilthey, Klages y Jung. En efecto, y como recuerda Weber, “en lugar de proceder a partir de 'la existencia del hombre en la sociedad', estas tentativas, que invocan la 'literatura'. la 'naturaleza', la 'edad mítica', constituyeron una línea filosófica que (...) desembocó (...) en el fascismo" (Weber, 2014, p. 488). Weber lee asimismo el pasaje como una autocrítica en la que Benjamin podría referirse a su propio Programm, en el que nos centraremos más adelante en este mismo capítulo.

Acerca de Dilthey, es importante recordar que éste coloca en el centro de su filosofía el concepto de Erlebnis ${ }^{143}$, que Benjamin tomará como contracara de su concepto de experiencia, pero con el que Dilthey buscaba también, por su parte, diferenciarse del concepto de experiencia heredado, esto es, la Erfahrung kantiana: "por las venas del sujeto cognoscente que construyeron Locke, Hume y Kant", dirá el autor, "no corre verdadera sangre, sino el diluido jugo de la razón como mera actividad mental” (Dilthey, citado por Jay, 2009, p. 266). En efecto, la crítica a la tradición, y específicamente el cuestionamiento a la filosofía centrada en el sujeto, como rasgo propio de la época, genera parentescos entre autores que luego se diferencian fuertemente en sus propuestas propias, como será posible explorar en relación a la filosofía de Heidegger en la próxima sección de esta investigación.

\footnotetext{
${ }^{143}$ La figura de Dilthey resulta muy relevante en tanto comparte con Benjamin el objetivo de incluir la experiencia histórica en los análisis filosóficos sobre la experiencia, objetivo que Benjamin deja claro ya en su texto sobre la filosofía kantiana de 1918.
} 
Volvamos al texto de Benjamin: allí, en el marco de su lectura de Dilthey, Bergson ${ }^{144}$, Proust y Freud ${ }^{145}$, aparece la oposición mencionada entre Erfahrung y Erlebnis en dos contextos. El concepto de vivencia, sin embargo, es utilizado antes, cuando Benjamin pone así lo presenta él mismo- en términos proustianos una idea de la teoría freudiana. Allí, argumenta que sólo podrá dejar huella en la memoria [Gedachtnisspur] lo que no fue vivenciado conscientemente (2008c, p. 214; GS I 613). Se delinea entonces ya cierta conexión entre la vivencia y los procesos conscientes del sujeto, que deja a la memoria involuntaria y a aquello que imprime una huella significativa fuera de los mecanismos propios del sistema de la conciencia. Ésta, a su vez, es caracterizada, con Freud, como cumpliendo la función de proteger al organismo contra los estímulos amenazantes del exterior, como los shocks (Benjamin, 2008c, p. 215), es decir que se le adjudica la función defensiva de frenar el impacto de aquello que podría resultar traumático para el sujeto. ${ }^{146}$

Vista esta primera explicitación del concepto de vivencia, atendamos ahora sí a los dos pasajes que delinean la diferencia con la experiencia en sentido estricto. En primer lugar, en un pasaje sobre el shock, se lee:

Que el shock sea atajado de tal modo, detenido así por la conciencia, le daría al suceso que nos lo ocasiona carácter de vivencia en sentido eminente. Y esterilizaría ese suceso (al incorporarlo de manera inmediata al registro consciente del recuerdo) para toda posible experiencia poética [dichterische Erfahrung]. (Benjamin, 2008c, p. 216; GS I 614. El enfatizado es nuestro)

\footnotetext{
${ }^{144}$ Benjamin se refiere a Matière et mémoire, publicado en 1896.

145 Tal y como Benjamin aclara, tomará algunas ideas de Más allá del principio de placer, de 1921, así como algunos desarrollos posteriores a Freud, particularmente los de su discípulo Theodor Reik [1888-1969], de quien cita el texto Der überraschte Psychologe: Über Erraten und Verstehen unbewusster Vorgänge [El psicólogo sorprendido: Sobre la conjetura y la comprensión de procesos inconscientes].

${ }^{146}$ Benjamin menciona también en este punto a Paul Valéry, quien plantea algunas ideas similares a las freudianas que Benjamin recoge también en otros escritos, entre ellos en su pequeño texto "Paul Valéry" que publica en Die literarische Welt en 1931 (Benjamin, 2008d).
} 
Otra vez, la vivencia se asocia a la conciencia y su función protectora, como si la significación de los acontecimientos se empequeñeciera cuando su impacto es controlado por esta barrera. La experiencia -que, en este caso, en el marco del estudio sobre Baudelaire, es específicamente la experiencia poética- requeriría que la potencia de lo vivido atravesara esa barrera e impactara más allá de lo consciente. La relación con la memoria es central: darle un lugar al acontecimiento en el plano consciente de los recuerdos lo esterilizaría para una experiencia más significativa. $\mathrm{Y}$ es que, como en Proust, el pasado que tiene potencialidad transformadora no es el de los recuerdos una y otra vez revisitados, que tienen su sitio en el museo de la historia personal y familiar, sino esos otros cuyo descubrimiento depende del azar.

En segundo lugar, en un pasaje similar, Benjamin vuelve a oponer vivencia y experiencia, esta vez sin referirse a la poesía. En sus palabras:

Cuanto mayor es la participación del momento de shock en las impresiones individuales, cuanto más incansablemente tiene que mantenerse la conciencia alerta en interés de la protección contra los estímulos, cuanto mayor es el éxito con que opera, tanto menos aquéllas lograrán penetrar en la experiencia [gehen sie in die Erfahrung ein], y así también tanto mejor realizarán el concepto de vivencia [erfüllen sie den Begriff des Erlebnisses]. (Benjamin, 2008c, p. 217; GS I 615)

Ya más explícitamente, la conciencia es presentada como una barrera que administra los estímulos y controla el ingreso al organismo, generando, con el material de dichos estímulos, vivencias. La experiencia, por su parte, aparece ligada a aquello que, escapando de esa instancia, se realiza en algún nivel diferente en el que el sujeto tiene menos control. El carácter de pérdida que supone la mera elaboración de lo sucedido como vivencia queda claro cuando Benjamin sostiene que "asignar al suceso, a costa de la integridad de su contenido [auf Kosten der Integrität seines Inhalts], un exacto punto temporal en el interior de la conciencia (...) sería un logro extraordinario de la reflexión en cuanto tal, haciendo del suceso una vivencia 
[den Vorfall zu einem Erlebnis machen]" (2008c, p. 217; GS I 615. El enfatizado es nuestro).

Pasar lo vivido por el tamiz de la conciencia para asignarle un tranquilizador punto fijo en la memoria voluntaria tiene, como costo, el empobrecimiento de la potencia que el acontecimiento reviste, es decir, implica una renuncia a la intensidad y a la transformación y una entrega a la existencia anestesiada y automática. Contra dicha actitud es que Benjamin alza la figura de Baudelaire, y entiende de su mano a la producción artística como un proceso de duelo de esgrima ${ }^{147}$ "en el que el artista grita de espanto" (2008c, p. 217). Y es que, en lugar de neutralizar el shock para preservar la conciencia, Baudelaire "colocó (...) la experiencia del shock [Chockerfahrung] en el corazón de su trabajo", e "hizo causa de detener con toda su persona, espiritual y física, cualquier shock, da igual de qué viniera” (2008c, p. 218; GS I 616) ${ }^{148}$. Como detallaremos más adelante, el rol de la multitud o la masa es en el caso de Baudelaire tan importante como el de la ciudad misma, en tanto ambos propinan shocks al artista, y lo será a través suyo en la filosofía de Benjamin ${ }^{149}$. Pero volvamos a la distinción entre vivencia y experiencia.

En el texto que de momento nos ocupa quedan por reseñar dos aspectos relevantes para esta distinción, en tanto, por un lado, se hace más clara en relación con el eje del trabajo y la alienación y, por el otro, mediante un análisis de algunas dinámicas propias del juego de azar.

\footnotetext{
${ }^{147}$ Es el propio Baudelaire, en Le soleil, quien se retrata a sí mismo entregado a su trabajo poético practicando una "fantástica esgrima" [fastasque escrime] y "tropezando en las palabras como en los adoquines" [trébuchant sur les mots commes sur les pavés]. En Las clases de Hebe Uhart, Villanueva se refiere al modo en que Chéjov en realidad el fragmento, de 1928, sería del sobrino del escritor- hablaba de su propio proceso de escritura, que recuerda al baudelairiano: "Yo me cansaba de la multitud de impresiones exteriores a las que permitía influir en mí sin control alguno. Yo estaba materialmente despedazado por las impresiones más variadas e inarmónicas" (2015, p. 31).

${ }^{148}$ Muchos y muchas son los y las artistas que, en este mismo sentido, hacen del cuerpo propio el lugar de la experimentación artística. El caso de Marina Abramović es particularmente interesante. Sobre el proceso de producción de su obra, dice la artista: "Voy tan lejos que duele tanto que ya no puedo sentir nada" [Ich gehe so weit, dass es so weh tut, dass ich nichts mehr spüre] (en Fischer, 2018, p. 25).

${ }^{149}$ En torno a la interpretación benjaminiana de la poesía de Baudelaire, ver Gallegos (2015). Allí, el autor da cuenta del modo en que Benjamin es capaz de iluminar las implicancias políticas de dicha poesía, que se concentra en lo olvidado, en los restos y las ruinas del progreso, y es capaz por ello de convertirse en una praxis disruptiva y en una forma de intervención política. A su vez, actualizando el pensamiento de Benjamin, Gallegos lanza el desafío de pensar en las posibilidades del arte en la actualidad y se pregunta: ¿puede el arte hoy politizar la experiencia?
} 
En ambos casos, y en general en todo el texto, es importante atender al papel del tiempo y a los diferentes modos de experimentarlo.

\subsection{El ritmo y el tiempo de la experiencia: trabajo y juegos de azar}

El capitalismo, precisamente por esta condición intrínseca de carácter permanente, escapa hacia el futuro.

Byung-Chul Han, 2014, p. 16

En torno al trabajo y como señala Thomas Weber, "Benjamin asocia primero el concepto de experiencia al modo de producción artesanal” (2014, p. 500). En efecto, y refiriéndose a Marx ${ }^{150}$, compara la forma de trabajo artesanal con el modo reificado de trabajo que supone la cadena de montaje en la fábrica (Benjamin, 2008c, p. 235). En la producción capitalista, el obrero aprende a coordinar su movimiento con el de la máquina, mientras que en la manufactura tenía lugar aún lo que Benjamin llama ejercicio [el término alemán es Übung, que podría traducirse también como práctica], a través del cual cristaliza la experiencia en cada rama de la producción. Esta experiencia, ligada a la tradición del oficio y a la repetición no mecánica de una actividad, se ha perdido en la fábrica, que obliga al obrero no calificado a reproducir mecánicamente los mismos movimientos corporales. En palabras de Benjamin: "su trabajo es impermeable a la experiencia [gegen Erfahrung abgedichtet]" (2008c, p. 236; GS I $632)^{151}$, cuando por otro lado la experiencia debería darse como "fruto del trabajo" (Benjamin, 2013, p. 1228) en el contexto del trabajo no alienado.

\footnotetext{
${ }^{150}$ Benjamin cita en este caso El capital. Cabe destacar que la relación de Benjamin con la tradición marxista y los escritos de Marx es profunda e intrincada. Entre los trabajos que la abordan, desde perspectivas y con conclusiones bien diferentes, recomendamos consultar Kittsteiner (1986), Löwy (2005) y el apartado "Marxismus" en la historia de la recepción de Benjamin que Küpper y Skrandies (2011) realizan en el Handbuch de Benjamin, que recorre, a su vez, la bibliografía clásica sobre el tema.

${ }^{151}$ En el convoluto D de la Obra de los pasajes Benjamin reitera este motivo. En dicho marco, anota una cita de Engels que aparece citada también en el primer tomo de El capital: "La penosa rutina de un daño laboral interminable, en la que siempre, una vez y otra, se repite un idéntico proceso mecánico al modo del viejo trabajo
} 
Este tipo de movimiento y de conducta, además de ser propios del trabajo alienado, son los propios de las masas anestesiadas de transeúntes que circulan por la ciudad, y que "se comportan como si, adaptados al autómata, sólo se pudieran todavía seguir expresando automáticamente. Su conducta, en efecto, es sin duda reacción al shock” (Benjamin, 2008c, p. 236). Nuevamente, lo hecho y lo vivido no logran transformar al sujeto, sino que los estímulos son incorporados automáticamente a la conciencia y respondidos de modo automatizado. Benjamin ilustra esta existencia mecanizada y confusa con una muy expresiva imagen de Poe ${ }^{152}$ : "Cuando les empujaban, saludaban muy efusivamente al mismo que les diera el empellón” (Poe, citado por Benjamín, 2008c, p. 236).

Tanto en el ámbito del trabajo como en el entorno de la gran ciudad, la experiencia es difícil de encontrar y todo cuanto acontece da lugar a la mera vivencia. En este contexto, los ritmos de las diferentes esferas de la vida se acompasan en una medida tal que "a la vivencia del shock [Chockerlebnis] que el transeúnte tiene en la multitud corresponde la 'vivencia' del obrero con la maquinaria [das 'Erlebnis' des Arbeiters an der Maschinerie]' (Benjamin. 2008c, p. 236; GS I 632). Asimismo, y como mencionamos, este mecanismo alienado y de relación mecanizada con el mundo se repite en otro entorno que, contrario al trabajo en su sentido tradicional, se espeja a su vez en él, a saber, el juego.

El análisis benjaminiano del juego y de los juguetes, cargados de potencialidad política y creativa ${ }^{153}$, deja lugar en este caso a un fenómeno bien diferente: los juegos de azar, como forma de ocio que queda atrapada en la lógica del trabajo que imprime el capital. En su ensayo sobre Baudelaire, Benjamin se centrará en la figura del jugador dando cuenta del modo en que

\footnotetext{
de Sísifo: pues ahí el peso del trabajo, al igual que la roca, cae sin descanso, una vez y otra, sobre los mismos obreros agotados" (Benjamin, 2013, p. 203).

${ }^{152}$ Finalmente, Benjamin se aleja en este texto de la forma en que Poe se relaciona con la multitud de la ciudad, y reivindica el modo baudelairiano de estar con las masas. Volveremos sobre este punto más adelante.

${ }^{153}$ Chausovsky (2015) advierte cómo la atención benjaminiana a los juguetes supone el reconocimiento de su capacidad para enriquecer el mundo perceptivo y para la crítica de la relación con el objeto en términos puramente instrumentales.
} 
se comporta y se relaciona con el pasado y con el entorno, modo que se presenta como el propio de la vivencia. En efecto, y a partir de algunas ideas de Alain ${ }^{154}$, señala el parecido de la estructura temporal, de la peculiar secuencia de comenzar cada vez de nuevo, de la que caen víctimas tanto el jugador como el trabajador asalariado: como el obrero no calificado, el jugador repite una y otra vez el mismo movimiento, y obtiene una y otra vez el mismo resultado: "el trabajo de ambos se halla por igual, en consecuencia, libre de contenido como tal [von Inhalt (...) sehr befreit]" (Benjamin, 2008c, p. 238; GS I 633).

El tiempo que caracteriza a la experiencia no es el tiempo lineal del historicismo, sino un tiempo plagado de sentido, alejado del tiempo vacío, en una medida tal que es la experiencia la que lo "llena y articula" (Benjamin, 2008c, p. 239). En una nota que Benjamin no publicó en vida, pero que habría escrito entre 1931 y 1932 y que lleva por título “Zur Erfahrung” [Sobre la experiencia], es posible encontrar ya la idea de que el jugador se encuentra lejos de realizar el concepto de experiencia. Allí escribe Benjamin, categórico: "El tipo de hombre que experimenta es el contrario al del jugador" (Benjamin, 2017d, p. 113).

También en el Passagen-Werk se refiere Benjamin a la figura del jugador y a su relación con el tiempo. Allí, comparando las actitudes adoptadas frente al tiempo por el flâneur, aquel que aguarda y el jugador, dice sobre este último: "Dejar pasar el tiempo -rechazarlo, expulsarlo-" (2013, p. 205).

En la vivencia, y específicamente en la de los juegos de azar y el trabajo asalariado, “el empezar-de-nuevo-siempre-desde-el-principio [Immer-wieder-von-vorn-anfangen] constituye la idea regulativa" (Benjamin, 2008c, p. 240; GS I 636). Esta forma de experimentar el tiempo tiene efectos narcóticos, que lejos de manifestarse sólo en el juego configuran formas de estar

\footnotetext{
${ }^{154}$ Alain es el pseudónimo de Émile-Auguste Chartier [1868-1951], un filósofo y escritor francés entre cuyos ensayos se encuentra Les idées et les âges, de 1927, que Benjamin cita aquí.
} 
en el mundo que lo exceden. En este sentido, resulta muy relevante una nota que agrega Benjamin en el texto sobre Baudelaire:

Este curioso modo de pensar se ve favorecido por la apuesta, que constituye un medio de dar a los acontecimientos un carácter de shock, desligándolos de contextos de experiencia [sie aus Erfahrungszusammenhängen herauszulösen]. Para la burguesía, los acontecimientos políticos adoptan de igual modo fácilmente la forma de incidentes en la mesa de juego. (Benjamin, 2008c, p. 239, nota XIV; GS I 635. El enfatizado es nuestro)

Esta percepción del tiempo es característica, entonces, no sólo del jugador y del obrero mientras trabaja con y para la máquina, sino también de la clase burguesa en tanto no realiza el trabajo de memoria necesario para comprender las dinámicas en las que se inserta su propia vida. En su caso, la vivencia es el lugar de la negación, que implica refugiarse en la sorpresa como una forma de evadir la responsabilidad de su propia clase en el estado de las cosas. Esta evasión es característica también, como desarrollamos en el capítulo 3, de las relaciones estetizadas, marcadas por la exterioridad y la distancia con la que se percibe lo que ocurre. La burguesía que se asombra ante los acontecimientos políticos los coloca en el lugar de objetos de contemplación ante los que se maravilla o se espanta. El motivo se reitera en la Tesis VIII, en la que, como señalamos también en el capítulo 3, Benjamin critica a quienes se asombran de que el grado de violencia y terror del que fue testigo el siglo XX sea "“todavía' posible" (2009, p. 143) y escribe: "la idea de historia que provoca ese asombro no se sostiene" (2009, p. 143).

En "Panorama imperial", asimismo, de 1929, nuestro autor se refiere de una manera similar a la actitud burguesa frente a la situación política. Allí, alude al "tesoro de frases hechas en las que a diario se revela el estilo de vida del burgués alemán, esa fusión de estupidez y cobardía” (2014, p. 55), y presenta este pensamiento reduccionista como sigue: 
El aire está tan lleno de teorías sobre la vida y de cosmovisiones, que en este país dan la impresión de ser tan arrogantes porque casi siempre sólo valen para autorizar alguna situación privada sin importancia. Y precisamente porque cada cual se compromete con las ilusiones ópticas de su aislado punto de vista es que el aire también está tan lleno de quimeras y espejismos de un futuro cultural que, pese a todo, irrumpe floreciente de la noche a la mañana [einer trotz allem über Nacht blühend hereinbrechenden kulturellen Zukunft]. (2014, pp. 60-61; GS IV 98. El enfatizado es nuestro)

Los rasgos comunes, entonces, entre el jugador y el burgués serán al menos dos: por un lado, la incapacidad de "reconocer las oscuras fuerzas a las que se ha terminado sometiendo su vida" (Benjamin, 2014, p. 59), o el intento más o menos deliberado de evitarlo; por el otro, la confianza injustificada en un futuro en pos del que, por una u otra razón, no se trabaja o no se lucha, pero en cuya llegada se deposita la fe.

Al respecto, y basándose en las ideas de Koselleck ${ }^{155}$, Jay sostiene que en la modernidad la relación tradicional de continuidad con el pasado "fue reemplazada (...) por una alternativa temporal en la cual el horizonte de expectativa encuentra su legitimidad en un futuro imaginario que ya no está en deuda con el pasado" $(2009, \text { p. } 35)^{156}$. La ideología del progreso ${ }^{157}$, a la que nos referimos en el capítulo 3, se inscribe en este proceso. ${ }^{158}$

\footnotetext{
${ }^{155}$ Sobre la relación de Benjamin con Koselleck resulta muy relevante el texto de Habermas "La modernidad: su conciencia del tiempo y su necesidad de autocercioramiento" junto con el "Excurso sobre las tesis de Filosofía de la Historia de Benjamin", ambos incluídos en El discurso filosófico de la modernidad (1993). Asimismo, Carlos López (2018) explora esta afinidad sumando a su vez la perspectiva de de Rancière.

${ }^{156}$ En la segunda mitad del siglo XX, sin embargo, y específicamente "después de 1968 (...) el futurismo (el proveniente de la Ilustración) retrocede con fuerza y el presente (en el espacio que queda libre) se impone progresivamente como la categoría dominante, mientras que el pasado se oscurece" (Hartog, 2013, p. 65).

${ }^{157}$ Cabe mencionar en este punto el texto de Adorno "En recuerdo de Eichendorff", quien dirige una crítica similar a este escape de la tradición simplemente basado en "el gesto de "Eso ya no vale" (2003b, p. 68) propio de quien se opone al tradicionalismo y la nostalgia conservadora, pero de una manera acrítica y superficial. Asimismo, la forma en que el arraigo de la ideología del progreso se manifiesta en la forma de percibir y comprender la propia vida, que Benjamin detecta muy tempranamente, es especialmente actual. En el marco de lo que se conoce como "el giro afectivo", trabajan este tema Sara Ahmed (2019) y Lauren Berlant (2020).

${ }^{158}$ Vargas también retoma a Koselleck y da cuenta del "protagonismo del futuro y la pérdida del valor ejemplar del pasado" (2018, p. 37) en la modernidad clásica alemana.
} 
A partir de las formas mecanizadas del trabajo y del juego, como configuraciones que se replican a su vez en otros ámbitos, es posible delinear algunas precisiones más acerca de la diferencia entre la vivencia y la experiencia. Particularmente, es preciso dar cuenta del carácter de elaboración de la segunda, ausente en la primera en dos sentidos: en tanto la respuesta mecanizada no transforma, condenándose así a comenzar y terminar siempre en los mismos puntos, y en tanto se deslinda de todo marco histórico. En la Erlebnis tal y como aparece en el ensayo sobre Baudelaire, el pasado desaparece como instancia dadora de sentido en tanto el cuerpo funciona de forma refleja, sin ninguna elaboración que medie entre el estímulo y la respuesta. Benjamin lo deja claro en su descripción de una litografía de Senefelder:

el mecanismo al que se han entregado los jugadores en el juego de azar se apodera de ellos en cuerpo y alma, de modo que también en su esfera privada, por apasionadamente que se muevan, ya no son capaces de funcionar sino de forma refleja [nicht mehr anders als reflektorisch fungieren können]. Así, se comportan como los transeúntes en el cuento de Poe. Viven su existencia como autómatas [Sie leben ihr Dasein als Automaten]. (2008c, p. 238; GS I 634)

En efecto, Benjamin utiliza la palabra "estupefaciente" [Rauschgift $]$ para caracterizar esta actitud en los jugadores, que apuestan tratando de acallar sus pensamientos y embriagar su conciencia. Refiriéndose a la naturaleza cíclica de la relación con el juego, observa que quien participa en juegos de azar "está en tal disposición en la que no puede sacar mucho de sus experiencias [nicht viel Aufhebens von der Erfahrung machen kann]" (2008c, p. 239; GS I 635), y coloca el afán o el empeño del jugador, o incluso su codicia (Benjamin usa las palabras Bestreben y Gier y la forma finstere Entschlossenheit, haciendo alusión a una determinación oscura) separados del "deseo [Wunsch] en el sentido auténtico de esa palabra” (2008c, p. 239; GS I 635), que pertenece al orden de la experiencia y no al de la vivencia (2008c, p. 239). 
En dicho contexto, la figura de Baudelaire encarna a aquel que logra hacer una experiencia en el contexto de la crisis de la experiencia y donde todo beneficia a la mera vivencia. A diferencia de los jugadores,

[e]l poeta no toma su parte en el juego. Se encuentra callado, en un rincón, no más feliz que los jugadores. También él es un hombre defraudado en su experiencia, un moderno [ein um seine Erfahrung betrogener Mann, ein Moderner]. Pero el poeta rechaza el estupefaciente con el cual los jugadores tratan de sofocar al fin esa conciencia que los ha abandonado al paso que les marca el segundero. (Benjamin, 2008c, p. 241; GS I 636)

El punto de partida de Baudelaire no es diferente al de los jugadores, y lejos de retratarlo como alguien que no tiene nada en común con ellos, Benjamin se centra en la actitud de rechazo del estupefaciente que ellos aceptan sólo tras dar cuenta del dolor común que los emparenta. Al posicionar a Baudelaire como un moderno, Benjamin lo coloca en el centro mismo de la crisis de la experiencia: allí, no sin dolor y no sin practicar su agotadora esgrima, Baudelaire hace, contra todo pronóstico, una experiencia, evitando la posición resignada de quien se entrega a una existencia automatizada.

Benjamin señala, a su vez, la diferencia entre Baudelaire y Bergson en torno a su relación con el tiempo histórico que habitan: mientras que el primero "sostiene entre sus manos los pedazos dispersos de una auténtica experiencia histórica [die auseinandergesprengten Bestandstücke echter historischer Erfahrung]" (2008c, p. 249; GS I 633) y “expone por su parte la vivencia en total desnudez [das Erlebnis in seiner Blöße]” (2008c, p. 249; GS I 63), la durée de Bergson ${ }^{159}$ "es la quintaesencia de una vivencia que se pavonea con el prestado traje de aquella experiencia [im erborgten Kleide der Erfahrung einherstolziert]" (2008c, p. 249; GS I 643), galvanizando formas de experiencia pasadas como si fueran atemporales.

${ }^{159}$ Sobre la durée y en general la concepción del tiempo de Bergson, consultar Cherniavsky (2006). 
En cuanto a la actitud frente al tiempo, Baudelaire aparece distanciado de la nostalgia conservadora que Benjamin había criticado ya en "Experiencia y pobreza", y alejado también de la ideología del progreso y la fe infundada en el futuro. De hecho, Benjamin señala en "Parque central" que en Baudelaire hay un "tabú respecto del futuro [Tabu auf der Zukunft]" (2008c, p. 263; GS I 657) que explica la ausencia de pesimismo en el poeta: "En él no hay reflexión de ningún tipo sobre el futuro de la sociedad burguesa" (2008c, p. 263) ${ }^{160}$.

La experiencia del tiempo en Baudelaire delinea varios aspectos de la crítica a la ideología del progreso que Benjamin desarrolla en sus Tesis, en la que nos centramos ya en el capítulo 3. En efecto, Benjamin anota que "el interrumpir el curso del mundo [den Weltlauf zu unterbrechen] era la más profunda voluntad en Baudelaire" (2008c, p. 274; GS I 667), lo cual coincide con la imagen que puede encontrarse entre los materiales para el escrito "Sobre el concepto de historia”. Allí, Benjamin escribe:

Marx dice que las revoluciones son las locomotoras de la historia universal [die Lokomotive der Weltgeschichte]. Pero quizá sean las cosas de otra manera. Quizá consistan las revoluciones en el gesto, ejecutado por la humanidad que viaja en ese tren, de tirar del freno de emergencia [der Griff des in diesem Zuge reisenden Menschengeschlechts nach der Notbremse]. (Benjamin, 2009, p. 307; GS I, 1232)

El carácter de elaboración de la experiencia, como el accionar en el ámbito de la historia, puede consistir en una detención o un cambio de estado que esquiva el avance lineal y progresivo. Benjamin mismo da un ejemplo crucial. En sus palabras:

\footnotetext{
${ }^{160}$ La reticencia a referirse al futuro, propia también de Benjamin, aparece en el Fragmento B incluido en las tesis "Sobre el concepto de historia". Allí se lee: "sabido es que a los judíos les estaba prohibido escudriñar el futuro. La Torá y la oración les instruyen, por el contrario, en la recordación. Ésta desencantaba el futuro, al que sucumbían cuantos buscaban respuestas en los adivinos" (Benjami, 2009, p. 297). Si bien luego el futuro aparece como pura potencialidad revolucionaria, en tanto "cada segundo era la pequeña puerta por la que podía entrar el Mesías" (2009, p. 297), aparece por lo general como una instancia menos explorada que el presente y el pasado, "la constelación propia del judaísmo", como apunta Reyes Maye (2009, p. 298).
} 
Hay una experiencia absolutamente única de la dialéctica. La experiencia compulsiva, drástica, que refuta toda "progresividad" del devenir y muestra todo aparente "desarrollo" [alle scheinbare "Entwicklung”] como un vuelco dialéctico sumamente complejo, es el despertar de los sueños [das Erwachen aus dem Traume] (2013, p. 491; GS V 491)

El motivo del despertar es relevante en la filosofía de Benjamin en varios sentidos: siguiendo a Weidmann, cabe apuntar el importante rol que cumple el par sueño/despertar como punto de contacto con Proust en torno a la narración y la experiencia, en la filosofía de la historia y en relación con Marx, en torno a Freud y al modo en que el propio Benjamin anotaba cuidadosamente sus sueños, y en relación con el surrealismo y la teorización de la modernidad $^{161}$. A su vez, el despertar, en tanto no se distingue de manera tajante y radical del sueño, posibilita una experiencia de umbral. Volveremos sobre este motivo más adelante. Por ahora, nos interesa dejarlo presentado como un ejemplo que da cuenta de la posibilidad de una transformación que escapa de la progresión y la linealidad, que implica una elaboración y que presenta ya a un sujeto en menor control de sí que aquel que se había despertado de una vez y para siempre de su sueño dogmático.

A continuación, analizaremos algunas otras claves relevantes del concepto de experiencia que se va delineando a lo largo de los escritos de Benjamin. En su delimitación respecto del concepto de vivencia, la experiencia mostró tener un componente de mayor elaboración, y será ese rasgo el que explique también, en parte, cómo la noción de experiencia de Benjamin es capaz de dejar de lado, por un lado, al sujeto como punto de partida de la teorización y, por el otro, la separación entre el hombre y el mundo, supuesta en la forma tradicional de comprender la experiencia, que queda puesta en entredicho. Nos centraremos a continuación en estos dos aspectos.

${ }^{161}$ En torno al motivo del despertar en Benjamin, ver McCracken (2002, p. 152 y ss.). 


\subsection{Del sujeto de la experiencia al colectivo}

En las imágenes que aportan el jugador y el trabajador asalariado es posible rastrear ya la relación compleja que se articula entre experiencia, tradición, pasado y memoria en el contexto de la filosofía de Benjamin. En efecto, la delimitación misma de la Erfahrung con respecto a la Erlebnis involucra ya la dimensión de la temporalidad, y evita una comprensión deshistorizada de la forma en que nos relacionamos con el entorno. Michael Löwy describe a la Erfahrung como una "experiencia auténtica (...) -fundada en la memoria de una tradición cultural e histórica-" (2005, p. 29). Si bien la idea de autenticidad no es propia de la batería terminológica de Benjamin, sí es importante dar cuenta de cómo, mientras la Erlebnis es ubicada en la órbita de la existencia anestesiada, la evasión, los procesos de estetización y el historicismo, la Erfahrung se asocia a una elaboración de la tradición y a una valoración no conservadora del pasado a las que se apunta como tareas. En efecto, la Erlebnis, como vivencia inmediata y subjetiva, se limita a una relación del sujeto con el mundo aún no articulada, mientras que la Erfahrung implica ya un marco de sentido que excede al sujeto y en el que es ineludible el lenguaje en el que este se mueve.

La delimitación de un concepto de experiencia que no se base en la figura de un sujeto es una meta que Benjamin plantea ya en 1917 y que, tras muchos virajes en su pensamiento, nunca abandona del todo. El carácter compartido de la experiencia reviste una importancia central en su filosofía, y ayuda a comprender cuán alejado está su concepto de experiencia del kantiano, y en general de la conceptualización moderna. Es así que el "sujeto" de la experiencia no puede ser en Benjamin un sujeto individual, ni tampoco un sujeto trascendental universal y ahistórico, al que sólo le queda vivenciar, en todo caso, el mundo, pero que no puede hacer de él una experiencia si no cuenta con los elementos de una cierta tradición que dote su vivencia 
de sentido y la inscriba en un marco comunitario que la excede a la vez que hace posible su elaboración.

Detengámonos brevemente en el análisis del concepto de experiencia kantiano que desarrolla Benjamin en "Sobre el programa de la filosofía venidera"162, redactado entre noviembre de 1917 y marzo de 1918. Allí, se refiere a "la experiencia temporal" (2007d, p. 163) de Kant y plantea que "los filósofos (Kant incluído) no tuvieron conciencia de esta experiencia en toda su estructura como una experiencia singular temporal" (2007d, p. 163. El enfatizado es nuestro). La crítica que a continuación le dirige conviene citarla extensamente:

Kant quiso, sobre todo en los Prolegómenos, extraer los principios de la experiencia de las ciencias, y en especial de la física matemática, si bien en la Crítica de la razón pura la experiencia no era por cierto idéntica al mundo de objetos propios de esa ciencia; y aunque hubiera llegado a serlo para él, como ha sucedido con los neokantianos, el concepto de experiencia así identificado y determinado aún seguiría siendo el mismo viejo concepto de experiencia [alte Erfahrungsbegriff], cuyo rasgo más característico viene a ser así su relación no solamente con la consciencia pura, sino, al mismo tiempo, también con la consciencia empírica. Pero se trata precisamente de eso: de la noción de experiencia desnuda primitiva y obvia [nackten primitiven und selbstverständlichen Erfahrung] que a Kant, que compartía el horizonte de su época, le parecía ser la única dada e, incluso, la única posible. Y, sin embargo, esa experiencia era, tal como ya hemos indicado, una experiencia singular y temporalmente limitada; y, más allá de esta forma (que en cierto modo es propia para todos los tipos de experiencia), era una experiencia a la que, en sentido enfático, se podría llamar cosmovisión [Weltanschauung], que fue la propia de la Ilustración. Y, en los rasgos que aquí son esenciales, no se diferenciaba grandemente de la experiencia de los otros siglos correspondientes a la Edad Moderna. Esta fue una de las experiencias o visiones más bajas del mundo. (Benjamin, 2007d, p. 163; GS II 158-159. El enfatizado es nuestro)

\footnotetext{
${ }^{162}$ En defensa del carácter de programa del escrito, dice Benjamin que allí "no se trata de demostrar ninguna cosa, sino de presentar un programa de investigación" (2007d, p. 169). Como menciona Florencia Abadi, Benjamin opone las ideas de programa [Programm] y dogma [Dogma] en una carta que escribe en 1912 a Ludwig Strauss en relación al modo de leer a Hegel propio del círculo de Wyneken (Abadi, 2015, p. 53).
} 
Benjamin caracteriza entonces la noción kantiana de experiencia como limitada, y no tanto porque esté basada en la experiencia propia de una época, lo cual parece inevitable, sino porque pretende referirse a los principios de toda experiencia, sin ser consciente de su carácter epocal. Asimismo, la época es valorada como teniendo "una de las experiencias o visiones más bajas del mundo" (Benjamin, 2007d, p. 163) 163 " “cuya quintaesencia era la física de Newton" (Benjamin, 2007d, p. 163).

En su estudio sobre la crítica, Steiner sostiene que es este "concepto insuficiente de experiencia" (2014, p. 244) el que "habría despojado de eficacia la crítica del conocimiento de Kant" (2014, p. 244). Y es que para Benjamin, Kant acaba reduciendo "toda la experiencia a la experiencia científica" (Benjamin, 2007d, p. 168) o "experiencia mecánica” (2007d, p. 168).

Una de las objeciones más fuertes de Benjamin a Kant se basa en que en su teoría del conocimiento,

desempeña una función fundamental la noción, aun sublimada, de un yo individual corporal-espiritual [eines individuellen leibgeistigen Ich] que recibe las sensaciones mediante los sentidos y forma sus representaciones a partir de esa base. Pero esta noción es mitología; y por su contenido de verdad es equiparable a cualquier otra mitología del conocimiento [Erkenntnismythologie]. (Benjamin, 2007d, p. 166; GS II 161)

Para Benjamin, una concepción del conocimiento más productiva ${ }^{164}$ será aquella en la que "este concepto ya no se refiera en modo alguno a la relación entre dos entidades metafísicas [zwischen zwei metaphysischen Entitäten]" (Benjamin, 2007d, p. 167; GS I 163) habiendo encontrado una "esfera de total neutralidad en relación con los conceptos de objeto y sujeto"

\footnotetext{
${ }^{163}$ T. Weber interpreta este texto como parte de un abandono de la empiria por parte de Benjamin (2014, p. 487), en tanto entiende la crítica al kantismo como una crítica a toda forma de empirismo.

${ }^{164}$ Sobre la concepción benjaminiana del conocimiento, ver Abadi (2014).
} 
(Benjamin, 2007d, p. 167). En este sentido, su búsqueda se orientará a un concepto de experiencia en el que no adquieran prelación ni el sujeto ni el objeto al que este se enfrenta.

En el Programm se delimita, en efecto, más allá de un programa específico que es abandonado después, a saber, "acometer, bajo la típica que se corresponde al pensamiento kantiano, la fundamentación epistemológica de un concepto superior de la experiencia" (Benjamin, 2007d, p. 164), un "un posicionamiento frente a la metafísica" (Abadi, 2015, p. 55), en tanto "tal como se colige de este programa, una experiencia de grado inferior implica una realidad [Wirklichkeit] de grado inferior" (Abadi, 2015, p. 55). Dicho posicionamiento, y el programa de redefinición y ampliación de la experiencia (Abadi, 2015) que está a la base del escrito, lejos de ser abandonado junto con las pretensiones de acometerlo bajo la influencia de Kant, atraviesa como tarea toda la producción de Benjamin, aun cuando aquello que en cada caso se privilegie en el análisis cambie en función de cada texto, su contexto específico de producción y sus objetivos.

Esta crítica a la concepción kantiana de la experiencia y el conocimiento, y la búsqueda de un nuevo concepto de experiencia que sea capaz de dar cuenta, entre otras, de la experiencia histórica y de la experiencia religiosa (Benjamin, 2007d, p. 164; Amengual, 2008, p. 34), están, creemos, a la base de la concepción de la experiencia que desarrolla Benjamin posteriormente y que mantiene siempre estos dos ejes: por un lado, no limitar la experiencia a un solo aspecto de la vida humana; por el otro, no pensar a la experiencia como antesala del conocimiento sino como siendo ya, en algún sentido, conocimiento. En este punto seguimos a Amengual cuando afirma que el carácter de elaboración de la experiencia, que destacamos en el apartado anterior, está presente ya en este escrito temprano: la experiencia se aleja de ser un mero material (Amengual, 2008, p. 35), y mantendrá este rasgo en los escritos de los años 30.

Peter Fenves da cuenta de la operación algo paradojal que pone en marcha Benjamin, en tanto moviéndose en el terreno de Nietzsche y Feuerbach, en la medida en que "también su 
escrito busca desarrollar un concepto de experiencia que no se parezca a ninguna consideración previa" (Fenves, 2011, p. 134), elige comenzar con Kant. Y es que tanto para Benjamin como para Kant la tarea de delinear un concepto de experiencia reviste una importancia central. A su vez, la crítica a Kant esclarece la posición de Benjamin, en tanto quiere alejarse de una filosofía de la subjetividad y de la conciencia, y no sólo de la conciencia empírica sino también de la conciencia en general (Fenves, 2011).

El sistema kantiano da cuenta, paradójicamente, tanto de la centralidad de la experiencia cuanto de la "la pérdida de fe en la posibilidad de esa experiencia integrada, equilibrada, holística, aunque siempre flexible y provisoria, tan celebrada en los Ensayos de Montaigne" (Jay, 2009, p. 43). La experiencia en la que se basa Kant, bajo el influjo de la "ceguera religiosa e histórica de la Ilustración [religiöse und historische Blindheit der Aufklärung]" (Benjamin, 2007d, p. 164; GS II 159), “carecía prácticamente de valor en su sentido propio” (Benjamin, 2007d, p. 163) y "solamente hubiera podido obtener un significado (diríamos que triste) mediante su certeza" (Benjamin, 2007d, p. 163), mientras que en Benjamin la experiencia tiene un potencial desestabilizador de toda certeza.

Una filosofía que renuncie a todo camino que no sea el recto no será capaz, para Benjamin, de dar cuenta de la textura de nuestra experiencia en un sentido cabal, integrando sus diferentes posibilidades y dando cuenta de su carácter situado, de su relación con la tradición y de la importancia que revisten para su configuración el pasado y la rememoración.

Nos interesa entonces recuperar dos aspectos del texto sobre Kant: por un lado, la crítica a la reducción de la experiencia a la esfera del conocimiento científico y el reconocimiento de su carácter integral e histórico; por el otro, la crítica al sujeto en que dicha experiencia y dicho conocimiento encuentran inscripción.

En torno al primer punto, en Infancia e historia, Agamben realiza una actualización de esa crítica a una noción cientificista de experiencia, y piensa en la potencialidad de recuperar 
algo del tipo de saber del "sentido común" (2011, p. 15) como lo propio de la experiencia, y separarlo del conocimiento en el sentido en que lo entiende la ciencia.

Benjamin mismo, en la Obra de los pasajes, se refiere al método del materialismo histórico y sostiene: "El materialismo histórico se apoya en su proceder en la experiencia, en el sano criterio que deviene de lo que conocemos por el nombre de sentido común [den gesunden Menschenverstand]" (2013, p. 767; GS V 596). A su vez, al pensar en el sujeto propio del sentido común es imposible mantener la referencia a un sujeto ahistórico: el sentido común está necesariamente informado históricamente y es propio, no de un individuo, sino siempre de una comunidad concreta.

La idea de una "experiencia separada del conocimiento" (Agamben, 2011, p. 15), que retoma aquella experiencia de los Essais de Montaigne, recupera el sentido práctico de elaboración de la concepción benjaminiana de la experiencia tanto como su carácter colectivo e histórico. La ciencia moderna, dirá Agamben, “en su búsqueda de la certeza (...) hace de la experiencia el lugar -el 'método', es decir, el camino- del conocimiento" (2011, p. 17), y desdobla a su paso al "viejo sujeto de la experiencia" (2011, p. 23).

Asimismo, Agamben reconoce en Proust a uno de los principales objetores del “concepto moderno de experiencia" (2011, p. 55), en tanto su obra sacude las bases de las condiciones que la hacen posible en el universo conceptual kantiano, a saber, por un lado, el tiempo y el espacio y, por el otro, la figura misma del sujeto que experimenta, que en la Recherche se diluye dando lugar a la figura, paradójica para quienes anclan el concepto de experiencia en las arenas del yo, de "una experiencia sin sujeto" (Jay, 2009; Melamed, 2012) que se hila, enrevesada, en el "complejo ensamblarse de las frases de Proust" (Benjamin, 2007c, p. 321) y se vive como "una infinita deriva y un casual entrechocarse de objetos y sensaciones" (Agamben, 2011, p. 56). 
Otro aspecto del Programm que cabe atender como parte de la redefinición de la experiencia como algo colectivo, y que es a su vez una constante en la producción benjaminiana, es el rol del lenguaje.

Allí, escribe Benjamin: “La gran transformación y corrección que hay que llevar a cabo en el concepto de conocimiento de unilateral orientación matemático-mecánica sólo puede obtenerse desde luego al ponerse el conocimiento en la relación con el lenguaje [eine Beziehung der Erkenntnis auf die Sprache]" (2007d, p. 172; GS II 168). La reinserción de la filosofía entre las reflexiones que se articulan en el lenguaje, que Benjamin llevó a cabo también poniéndola en diálogo siempre con la literatura, las artes, la política y la escritura de la historia, y que vuelve en su obra en la importancia de la narración, en la exploración de los géneros literarios, en la conferencia sobre el autor como productor y en las reflexiones sobre la traducción, se hace presente ya aquí en este aspecto de la crítica a Kant, de quien se señala que habría olvidado "que todo conocimiento filosófico tiene su única expresión en el lenguaje, y no en las fórmulas ni en los números [die Tatsache daß alle philosophische Erkenntnis ihren einzigen Ausdruck in der Sprache und nicht in Formeln und Zahlen]" (Benjamin, 2007d, p. 172; GS II 168. El enfatizado es nuestro) ${ }^{165}$.

La experiencia se da ya siempre en el lenguaje, y no es una instancia muda que se expresa simplemente en él. En este sentido, cabe traer a colación lo que Benjamin sostiene en una de sus Denkbilder: “el decir no es sólo la expresión, sino la realización del pensamiento. De la misma forma el andar no es sólo la expresión del deseo de alcanzar una meta sino su realización” (Benjamin, 2011a, p. 153).

\footnotetext{
${ }^{165}$ Como escribe Agamben recuperando ideas de Johann Georg Hamann, "Haber orientado el conocimiento sobre el modelo de la matemática le impidió a Kant, al igual que a Husserl, advertir la situación original de la subjetividad trascendental en el lenguaje y trazar por ende con claridad los límites que separan lo trascendental de lo lingüístico. Esa omisión hace pues que en la Crítica la apercepción natural se presente, como si fuera natural, como un 'yo pienso', como un 'sujeto lingüístico' (2011, p. 58).
} 
En el fondo de esta idea y como comentaremos más ampliamente en el capítulo 7 de esta investigación, resuenan otra vez motivos proustianos. Melamed se refiere, en este sentido, al "papel crucial del lenguaje en la conformación de la experiencia, del carácter eminentemente lingüístico de la experiencia” (2018) que se manifiesta en la En busca del tiempo perdido. Ello, continúa la autora,

resulta confirmado en diferentes niveles: en el recorrido de los personajes, en las experiencias suscitadas en el lector a lo largo de la lectura, y también en la capacidad de la novela de proporcionar condiciones para conformar experiencias en un plano extraliterario. Por dar un ejemplo obvio, que un sencillo sabor de una galleta transporte al mundo de la infancia se convierte en una experiencia luego de que Proust lo iluminara, al reconstruirlo poéticamente y convertirlo en un motor de la narración. (Melamed, 2018, p. 3)

La articulación entre experiencia y formas de narrar, que abordamos ya en el capítulo 4, es aquí muy relevante. En el seno de dicha relación, el diagnóstico de Benjamin determina una crisis en la experiencia cuando la capacidad de compartir lo vivido se encuentra en retirada, lo que genera una ruptura de los lazos generacionales y la tradición en un sentido tal que adquiere relevancia política.

No obstante, es importante atender a los matices de la posición benjaminiana respecto de la tradición y la autoridad que están implicadas en figuras como la del narrador. En este contexto, un antecedente relevante es el texto de juventud "Experiencia" ["Erfahrung"].

Allí, un joven Benjamin escribe bajo el pseudónimo de "Ardor" que "la máscara del adulto se llama 'experiencia'. Siempre igual, inexpresiva, impenetrable [ausdruckslos, undurchdringlich, die immer gleiche]" (2007f, p. 54; GS II 54). La experiencia es, en el contexto de este escrito, aquello que alegan tener los adultos para desmerecer las ideas de los jóvenes; la experiencia que ostenta una generación que ya ha aprendido que de la juventud se sale y que, al hacerlo, se percibe que los adultos siempre habían tenido razón. El adulto que 
piensa así desvaloriza, en palabras de Benjamin, “de antemano los años que nosotros estamos viviendo, los convierte en la época de los dulces disparates juveniles, en la embriaguez infantil [kindlichen Rausch] ante la larga sobriedad de la vida seria" (2007f, p. 54; GS II 54). Ahora bien, cuando interrogan qué es lo que han experimentado los adultos, los jóvenes se encuentran con que se trata de "la falta de sentido de la vida" (2007f, p. 55): las ilusiones y los anhelos de la "breve noche" (2007f, p. 54) de la juventud serán irremediablemente aplastados por "la pobreza de ideas y la falta de brío" (2007f, p. 54) que acompañan al despertar de la vida adulta. Frente a esa experiencia que ofrece el mundo de sus padres, Benjamin propone recuperar los valores inexperimentables de la verdad y la lealtad. Al hacerlo, pone el énfasis en la importancia de que el mundo no se limite a una eterna repetición de lo mismo, esto es, de la posibilidad de que surja la novedad. En este sentido, la experiencia que aporta la juventud en nombre de la cual escribe Benjamin es "que existe la verdad, aunque todo lo que se haya pensado hasta ahora resultara un error. O que hay que ser leal, aunque nadie lo haya sido nunca hasta ahora" (2007f, p. 55). Así, el texto termina con una apelación a "otra experiencia" (2007f, p. 56) que conocen los jóvenes que no se dejarán adormecer por el ritmo de aquel para quien la vida está limitada a ser lo que siempre fue.

Aun cuando se trata de un texto escrito por un Benjamin joven y bajo el influjo del círculo de Wyneken, del que luego se alejará, es posible encontrar un cierto eco de algunos de sus postulados en textos posteriores, como "Experiencia y pobreza". El breve texto suele ser considerado, en los estudios académicos sobre la experiencia en Benjamin, a lo sumo como un antecedente que pone de relevancia cierta continuidad en el motivo, pero que muestra grandes cambios en el enfoque. Weber, por ejemplo, sostiene que "la aspiración metafísica de Benjamin se transforma progresivamente en una 'pasión dialéctica' por lo histórico-concreto" (2014, p. 479). 
En nuestro caso, creemos que su significación es mayor ${ }^{166}$. En el texto de 1913, sin referirse a lo histórico-concreto -retomando la expresión de Weber-, Benjamin lo analiza en la figura de los adultos cansados y derrotados que le ofrece su paisaje epocal. La experiencia que describe en este texto representa ya una autoridad en crisis, y es ya de algún modo una muestra de galvanización y una forma de evasión. En efecto, es la destrucción de esta forma autoritaria de trasmisión y la construcción de otras formas de elaboración de la tradición lo que posibilita pensar en la supervivencia de algún tipo de experiencia.

En torno a la relación de la experiencia con la tradición, es importante recordar que Benjamin sostiene, ya en la década del 30, que la experiencia es cosa de la tradición (2008c, p. 210). En su crítica a Bergson y a cómo éste "rechaza toda clase de determinación histórica de la experiencia” (Benjamin, 2008c, p. 210), así como en el cuestionamiento a Kant, el berlinés da cuenta de la importancia de no negar la experiencia histórica de la que surge la propia filosofía.

En este sentido, y si bien Benjamin coincide con Bergson en torno a la relevancia de la memoria "para la estructura filosófica de la experiencia" (Benjamin, 2008c, p. 209), la memoria a la que apelará, por un lado, tendrá siempre un anclaje histórico concreto y, por otro, se acercará más a la memoria involuntaria tal y como aparece en Proust ${ }^{167}$ que a la memoria pura bergsoniana.

Benjamin pone todos sus esfuerzos filosóficos en no entregarse a los relatos cegadores de la tradición filosófica, que ocultan su carácter normativo en descripciones pretendidamente universales del hombre y del mundo. Su filosofía no esconde su carácter situado tras la máscara

\footnotetext{
${ }^{166}$ El estatuto de los escritos tempranos y su relación con la obra más tardía de Benjamin son temas de debate. Hay autores que prefieren marcar un viraje más radical en el pensamiento de Benjamin por la época en la que redacta Calle de dirección única, en 1929, y otros que hacen mayor hincapié en las continuidades. Entre los segundos, Steiner sostiene que "el giro hacia el pensamiento político" es "menos sorprendente de lo que se suele exponer" (2014, p. 249).

${ }^{167}$ Sobre Proust, dirá Benjamin "La obra de Proust, À la recherche du temps perdu (...) encierra en sí una crítica inmanente de las formulaciones bergsonianas" (Benjamin, 2008c, p. 210).
} 
de lo universal, ni se subleva, como la de Bergson, a la experiencia de la que surge, sino que, como Baudelaire, la "pone a la vista indeformada" (2008c, p. 210).

Refiriéndose al concepto de Erfahrung, dirá Jay en este sentido que

activa el vínculo entre memoria y experiencia, un vínculo que subyace a la creencia de que la experiencia acumulativa es capaz de producir un tipo de sabiduría que solamente se alcanza al final del viaje. Si bien no siempre es el caso, Erlebnis a menudo indica la condición inefable del individuo, mientras que Erfahrung puede tener un carácter más público, colectivo. (2009, p. 28)

El autor, en efecto, al oponer "inefable" a "público", da cuenta de cómo el vínculo entre experiencia y comunidad -o experiencia y tradición- está ligado al carácter comunicable de la experiencia. La narración, por ejemplo, no aparece en Benjamin como "expresión” de las experiencias que se dan fuera de ella, en el seno de la interioridad del sujeto, sino como el espacio para su configuración misma como experiencias.

Pablo Oyarzún se ha ocupado de este vínculo en su introducción a El narrador (2010). Allí, sostiene que la matriz de este texto benjaminiano es justamente "la relación entre narración y experiencia" (2010,p. 9), en tanto la narración no se estudia como objeto literario, sino más bien como instancia donde encontrar la experiencia y su crisis. La comunicabilidad de la experiencia a la que se refiere Benjamin es interpretada por Oyarzún como parte esencial de la experiencia misma que, lejos de ser el mero material que se comunica, deviene experiencia al devenir común en la comunicación. Asimismo, en su artículo "Indagaciones sobre el concepto de experiencia" (1998), Oyarzún ofrece importantes claves para comprender el fenómeno de la crisis a la que nos referimos en el capítulo 4, al caracterizar a la experiencia como intransferible a la vez que como comunicable, esto es, como necesariamente articulada en el lenguaje, pero como irreductible a él. La experiencia, en su concepción, no es anterior al lenguaje ni está separada de él, sino que encuentra en el lenguaje el medio que la hace posible, 
en tal medida que la mudez de los soldados que vuelven del frente es sinónimo, en "Experiencia y pobreza", de una incapacidad para hacer experiencia. En este mismo sentido, Benjamin afirma acerca del narrador que su tarea [Aufgabe] consiste, como la del artesano, en "elaborar la materia prima de las experiencias -ajenas y propias- de forma sólida, útil y única [den Rohstoff der Erfahrungen -fremder und eigener-auf eine solide, nützliche und einmalige Art zu bearbeiten]" (2008, p. 95; GS II 464). El contenido que se "encierra" en la narración, como recupera Honold, "no puede ser disociado del así-y-no-de-otro-modo del proceso narrativo" (2014, p. 815).

Las referencias a la importancia de la tradición y del lenguaje, así como el análisis de la narración y de los vínculos generacionales y comunitarios que vehiculiza, son algunos de los indicios que permiten comprender el carácter eminentemente colectivo de la experiencia en Benjamin, que no puede ser pensada como la experiencia de un sujeto. De igual modo, la experiencia histórica potencialmente revolucionaria será la experiencia de un colectivo, que se relaciona a su vez con la agencia de aquellos que lo precedieron. El pasado y la tradición no implican nunca en Benjamin referencias conservadoras, sino siempre de reelaboración colectiva de la historia y de las tradiciones en que los colectivos se insertan, incluidas la filosofía y la misma lengua. En este sentido, su concepción se refleja en las siguientes palabras de Adorno: "La experiencia sería la unidad de la tradición y el abierto anhelo de lo extraño" (Adorno, 2003, p. 68).

El cuestionamiento de la figura de un sujeto, a su vez, excede al mero cuestionamiento de las características, capacidades o modos de interactuar de ese sujeto: el foco en la experiencia implica un corrimiento del motivo de la subjetividad ${ }^{168}$ que se abre a una exploración de esos encuentros con lo otro que ponen en duda la categoría misma de sujeto.

\footnotetext{
${ }^{168}$ En este sentido, es relevante también la exploración de la embriaguez [Rausch] que pone en marcha Benjamin. Para Abadi (2015), la embriaguez surrealista es central en el proyecto de ampliación de la experiencia que lleva a cabo Benjamin.
} 


\subsection{De la experiencia del mundo a la experiencia con él}

Parto del confuso registro de la experiencia, del despliegue de los cuerpos en los mundos y de lo que denomino "el drama de la contingencia"; es decir, de qué manera nos ofecta aquello que aparece a nuestro alrededor.

Sara Ahmed, 2019, p. 62

Por último, y como mencionamos en el capítulo 3, el alejamiento de la concepción tradicional de la experiencia y del sujeto moderno que la encarna que pone en marcha Benjamin estaría incompleto si no nos detenemos también en la forma en que el mundo es redefinido. Y es que, en efecto, la potencialidad de desarmar el binomio sujeto-objeto habita ya en el concepto mismo de experiencia. Jay lo expresa de la siguiente manera: "dado que se refiere tanto a lo que se está experimentando cuanto al proceso subjetivo de experimentarlo ${ }^{169}$, la palabra suele operar como un 'término paraguas' para superar la escisión epistemológica entre sujeto y objeto" ${ }^{170}$ (Jay, 2009, p. 28).

En ese mismo sentido lo entiende Thomas Weber, para quien

el de experiencia es un concepto articulatorio, en el cual la articulación ha de entenderse en el doble sentido, como vinculación y como expresión. La experiencia es una dimensión de la praxis humana en la que la relación con uno mismo y la relación con el mundo están articuladas de tal manera que la relación con el mundo se vuelve articulable como relación con uno mismo y viceversa. (Weber, 2014, p. 489)

\footnotetext{
${ }^{169}$ En este mismo sentido, cabe señalar, se expresa en alguna medida Vargas sobre el concepto de "crisis", que acompaña a la experiencia en la filosofía de Benjamin y sus recepciones, como vimos en el capítulo 4. En sus palabras: "El término crisis permite expresar tanto el estado anímico que acompaña a la incertidumbre sobre el desenlace de los acontecimientos, es decir, la experiencia subjetiva y la forma de denominarla, como los cambios objetivos que abren paso a lo incalculable" (Vargas, 2018, p. 34).

${ }^{170}$ En este punto, Jay agrega que "los pragmatistas norteamericanos eran especialmente proclives a usarlo de esta manera" (2009, p. 28). En efecto, entre Benjamin y el pragmatismo, especialmente algunas ideas de Dewey, hay algunas cercanías que es interesante explorar. Leopoldo Rueda y yo hemos trabajado sobre algunos paralelismos en las concepciones del arte de ambos pensadores en "Hacia otra comprensión de lo social en el arte: Dewey y Benjamin" (Rueda y Staroselsky, 2020).
} 
Como mencionamos, Benjamin critica desde los escritos tempranos la matriz de la representación de la que se vale la filosofía al entender al mundo como algo colocado enfrente de un sujeto. Y es que, como reconoce Jay,

por mucho que interpretemos a la experiencia como una posesión personal -"nadie puede quitarme mis experiencias", se alega en ocasiones-, inevitablemente se la adquiere a través de un encuentro con la otredad, sea humana o no. Esto es, independientemente de cómo se la defina, una experiencia no puede limitarse a duplicar la realidad previa de quien la sobrelleva y dejarlo, por decirlo así, en donde estaba antes; es preciso que algo se modifique, que acontezca algo nuevo, para que el término sea significativo. Ya sea una "caída" de la inocencia o la adquisición de un nuevo saber, un enriquecimiento de la vida o una amarga lección acerca de sus locuras, algo digno del nombre 'experiencia' no puede dejarnos, repito, donde comenzamos. (Jay, 2009, pp. 20, 21)

Para que esta transformación tenga lugar hace falta, como atendimos en los capítulos anteriores, la cercanía del mundo. El entorno aparece en la obra de Benjamin en una cercanía que se opone a toda estetización: sea la naturaleza o el mundo de los objetos, sea el pasado o la obra de arte, el sello es la tendencia a la proximidad. En torno a esta cuestión, es importante volver brevemente al escrito sobre Baudelaire, y explorar la dialéctica espacial que allí se despliega. La relación del poeta con la muchedumbre, que se compara con otras vinculaciones posibles, resulta muy reveladora.

Mientras que "Baudelaire no describe ni a la ciudad ni a los habitantes" (2008c, p. 223), la mirada distanciada que, como argumentamos, es propia de las relaciones estetizadas en las que reina el desinterés y la exterioridad se presenta en los ejemplos que prestan las descripciones de otros pensadores. El primer caso que expone Benjamin se basa en las descripciones que de la masa realiza Friedrich Engels en La situación de la clase obrera en Inglaterra, en las que se observa el extrañamiento y hasta el temor que la multitud urbana le 
provoca: "la congestión de las calles tiene ya algo repugnante, algo contra lo cual muestra naturaleza se rebela" (Engels, citado por Benjamin, 2008c, p. 221), dirá el pensador, en una reacción de rechazo que Benjamin entiende como moralmente orientada, pero también estéticamente motivada.

El caso de Poe es asimismo relevante. En El hombre de la multitud pinta la siguiente escena:

La calle es de las más vivas y animadas que hay en la ciudad (...) dos densas, masivas corrientes de transeúntes pasaron por delante del café (...) paladeé la nueva excitación que al contemplar el océano de ondeantes cabezas me había sobrevenido de repente. Luego, poco a poco, fui dejando de prestar atención a lo que ocurría en el espacio en el cual me encontraba, y me perdí en la contemplación de aquella escena callejera [Ich verlor mich an die Betrachtung der Straßenszene]. (citado por Benjamin, 2008c, p. 227; GS I 624. El enfatizado es nuestro)

El observador, protegido a la vez del caos de la muchedumbre y de las calles de la ciudad, observa una escena de la que no forma parte y la analiza. La contemplación es tal que aquel que mira se pierde en el cuadro que captura toda su atención. La relación se presenta, en este caso, como una relación estética. La masa que por allí pasa es así el objeto de este ejercicio de inmersión en la obra. A su vez, Benjamin remarca que, como Engels, Poe advierte "en el espectáculo [Schauspiel] que se le ofrecía (...) una amenaza [etwas Bedrohliches]” (2008c, p. 229; GS I 626). Ahora bien, tal y como lo sugiere el cambio en el tipo de experiencia estética que signa la época, el observador que construye Poe, finalmente, "sucumbe por entero a una atracción que terminará por arrastrarlo al torbellino de la multitud” (2008c, p. 231).

Un caso más extremo es el que ofrece Hoffman en El primo de la ventana de chaflán:

Ese primo de quien habla Hoffmann es en realidad un paralítico, asomado y solo en su ventana, que no podría seguir esa corriente aunque la sintiera en su persona. Allí, 
elevado sobre la multitud, como lo sugiere la atalaya en la que se encuentra su vivienda, va pasando revista a los que pasan (...) Sus anteojos de ópera le permiten aislar como escenas de género. La actitud interna del usuario es correspondiente totalmente con el empleo normal de este instrumento [Dem Gebrauch dieses Instruments ist die innere Haltung des Benutzers durchaus entsprechend]. Lo que pretende es, según confiesa, iniciar así a sus visitantes en las "primicias del arte de mirar" [Primitien der Kunst zu schauen], y este consiste en la capacidad de disfrutar cuadros vivientes [sich an lebenden Bildern zu erfreuen]. (Benjamin, 2008c, p. 231. GS I 628-629. El enfatizado es nuestro)

La relación estetizante con el entorno es enfatizada por el mismo Benjamin: los anteojos de ópera, como los aparatos ópticos que estructuran esta experiencia, reafirman su carácter estético.

Sin embargo, el caso de Baudelaire es totalmente diferente: la masa no es observada distanciadamente, sino que está estampada [eingeprägt] (GS I 618) en la obra del artista. El poeta se sitúa, con respecto a la masa, de otra manera:

Por lo que concierne a Baudelaire, la masa le es tan poco algo exterior que en su obra puede rastrearse cómo, deslumbrado y atraído, se defiende de ella al mismo tiempo. La masa es tan intrínseca a Baudelaire que en vano se busca en él su descripción [Die Masse ist Baudelaire derart innerlich, daß man ihre Schilderung bei ihm vergebens sucht]. Y es que los más importantes de sus temas casi nunca se encuentran en forma de descripciones en su obra. (2008c, p. 223; GS I 621. El enfatizado es nuestro)

Él no mira a esa masa desde fuera, y tampoco forma parte de ella: en una actitud ambivalente, "se hace su cómplice mientras que casi en el mismo instante se separa de ella" (Benjamin, 2008c, p. 229). Y es que el público de la calle será, volviendo a la terminología de Déotte a la que recurrimos en el capítulo 4, no un objeto de contemplación estética o de observación científica, sino de algún modo el aparato que estructura la experiencia del poeta. 
En palabras de Benjamin: "la masa era el velo en movimiento [der bewegte Schleier] a cuyo través se ve París en la poesía de Baudelaire” (2008c, p. 224; GS I 622) ${ }^{171}$.

Otro aspecto de las observaciones de Baudelaire sobre la masa que se resignifica y adquiere importancia en la filosofía de Benjamin es su consideración de los shocks como parte de la forma en que la técnica modifica la experiencia en la modernidad. En palabras de Benjamin, "la técnica sometió al sensorio humano a un entrenamiento de índole compleja" (2008c, p. 234), y este entrenamiento se revela en las descripciones de nuestro intercambio con el ambiente: "Baudelaire nos habla así del hombre que se sumerge en una multitud como en una reserva de energía eléctrica. Lo define en seguida, como 'un caleidoscopio que se encuentra provisto de conciencia"” (2008c, p. 234. El enfatizado es nuestro).

En torno a este uso, por demás recurrente, de imágenes ligadas a la electricidad y al sistema nervioso -shock, circuitos, descargas, reservas, energía- resulta relevante el artículo "Estética y anestésica: una reconsideración del ensayo sobre la obra de arte”. Allí, Buck-Morss analiza algunos de los desplazamientos que realiza Benjamin para pensar la relación del hombre con el mundo y se centra en las referencias al aparato perceptivo, a la sensibilidad y a la corporeidad que habitan su obra, así como al modo en que incorpora en su estética el análisis de la respuesta orgánica a los shocks, de manera que sostiene que "la comprensión benjaminiana de la experiencia moderna es neurológica. Tiene su centro en el shock” (BuckMorss 2015, p. 174). En ese marco, sostiene que, para Benjamin,

el sistema nervioso no está contenido dentro de los límites del cuerpo. El circuito que va de la percepción sensorial a la respuesta motora comienza y termina en el mundo [...] El campo del circuito sensorial, entonces, se corresponde con el de la “experiencia”, en el sentido filosófico clásico de una mediación de sujeto y objeto, y sin embargo su misma composición vuelve simplemente irrelevante la así llamada

\footnotetext{
${ }^{171}$ En El nervio óptico, María Gainza se refiere a la ciudad de Baudelaire y escribe: "en el París de fin de siglo la gente estaba demasiado ocupada estetizando todo" (2017, p. 144).
} 
“división entre sujeto y objeto", que era la plaga persistente de la filosofía clásica. (Buck-Morss, 2015, p. 170)

Efectivamente, hacer hincapié en el carácter de circuito de la interacción entre el sujeto y el mundo logra dar prelación a las continuidades en lugar de enfatizar el límite entre el adentro y el afuera. El espacio del umbral se vuelve habitable, y el cuerpo mismo adquiere porosidad.

En su estudio sobre la destrucción, Galende enfatiza este movimiento benjaminiano y da cuenta de cómo permite repensar la experiencia desde una óptica novedosa. Refiriéndose a El carácter destructivo, sostiene que

Benjamin parece tener ya muy presente la posibilidad de que el "viviente" traspase esta coraza fantasmagórica del sujeto soberano. Lo mismo sucede con su objeción respecto del límite que la filosofía del sujeto impone a la cuestión de la experiencia. Esto quiere decir que, contra el mito de la autogénesis, Benjamin cuenta con el sistema nervioso, un sistema que está tan poco contenido al interior del complejo psicológico o del cuerpo humano como lo está la actividad pensante al interior del cerebro. (Galende, 2009, pp. 185-186. El enfatizado es nuestro) ${ }^{172}$

Asimismo, respecto de Proust y como mencionamos anteriormente, Benjamin llama la atención acerca de los otros sistemas - diferentes del sistema de la conciencia-que intervienen en la relación del sujeto con el mundo. Allí, en esas interacciones, lejos del sujeto agente y el mundo mudo, el cuerpo y sus extremidades emergen como tentáculos que no responden a la tiranía de la conciencia y en cuya actividad se involucran formas de memoria involuntaria. En palabras de Benjamin, Proust

\footnotetext{
${ }^{172}$ Una breve nota no publicada de Benjamin resulta en este sentido ilustrativa. Se trata de una anécdota protagonizada por Ernst Joël, quien participó del Movimiento de la Juventud con Benjamin y lo acompañó en la supervisión de sus experimentos con hachís. Benjamin refiere esta anécdota como ejemplar en torno a la "descarga de energía traumática en las cosas [Entbindung der traumatischen Energie in den Dingen]" (2017h, p. 279; GS VI 200): un joven militar de la Guardia Roja había intentado quitarse la vida y, al hacerlo, había quedado ciego. Recordando ese hecho, el médico explica en una lección de anatomía, frente a un cráneo, que "se había disparado ahí. Para alcanzar el cerebro debió dispararse en este sitio. Donde termina la órbita ocular” (2017h, p. 279). Si bien Benjamin no explica la historia, consideramos que da cuenta del carácter de circuito que enmarca la relación entre el sistema nervioso y el aparato sensorial.
} 
no se cansa de hablar de las imágenes de la memoria ahí depositadas, y de cómo, sin obedecer a ninguna señal de conciencia, irrumpen [einbrechen] de manera no mediada cuando una cadera, un brazo o un hombro adoptan en la cama involuntariamente una posición en la que hace ya tiempo se habían colocado. (Benjamin, 2008c, p. 214; GS I 613)

En efecto, y si bien el descentramiento del sujeto es un tópico común en la filosofía del siglo XX, el cuestionamiento benjaminiano da lugar a una comprensión de la relación con el mundo que habilita planteamientos muy originales ya desde la obra temprana. Un ejemplo se encuentra en el Programa, al que ya nos referimos; el otro en "Destino y carácter", otro texto temprano, en este caso de 1921, donde Benjamin se centra justo en el punto de contacto entre esas dos entidades que se piensan, en la tradición filosófica, como independientes. En sus palabras:

Ningún concepto de mundo exterior [Außenwelt $]$ se deja delimitar con claridad en relación con el concepto de hombre actuante [des Begriffs des wirkenden Menschen]. Entre el hombre que obra y el entero mundo externo hay más bien una interacción recíproca [Wechselwirkung], en la cual los círculos de acción se esfuman el uno con el otro; por más que sus representaciones [Vorstellungen] puedan ser distintas, sus conceptos [Begriffe] no son separables [...] Lo externo, que el hombre actuante halla como dato, puede ser reconducido en último término, en la medida en que se desee, a su interior, y su interior, en la medida en que se desee, a su exterior, y también considerar al uno como el otro. (Benjamin, 2010a, p. 183; GS II 173)

El motivo de la distancia o la separación, que aquí se tematiza y que atendimos en torno al problema de la estetización en el capítulo 3, está presente desde los escritos tempranos. El eje espacial es, en Benjamin, tan importante como el del tiempo: en ambos casos, siguiendo de 
cerca el ejemplo proustiano, las linealidades tiemblan, y en ambos casos la memoria, otrora entendida como una pertenencia del sujeto, se encuentra volcada al mundo.

Respecto de esta cuestión, en su lectura de "El retorno del Flâneur", reseña de Benjamin de un texto de su amigo Franz Hessel, Esther Leslie (2007) sostiene que, al acortarse las distancias, algo del tiempo aparece en la configuración espacial. La diferencia entre la visión de la ciudad que tiene un nativo y la que tiene un turista radica en que, para el primero, la ciudad se abre en recuerdos de infancia. Así,

donde el turista buscaba lo superficial, exótico y pintoresco, el nativo, viajando al pasado y no solo a través del espacio, encontraba, en rincones y recovecos, los momentos de la infancia polvorientos y olvidados, incrustados en los mismos adoquines como gemas extraviadas. El espacio se ha convertido en una puerta al tiempo. (Leslie, 2007, p. 98)

La cercanía que otorga la inscripción de la propia memoria en el espacio hace posible una experiencia de la ciudad de la que carece quien la percibe distanciadamente como un objeto estético $^{173}$. En la lectura de Detlev Schöttker, de lo que se trata es de la vieja mnemotecnia, que consiste en

condensar los elementos de un discurso planeado en imágenes precisas o señales (...) pregnantes, y de fijarlas en lugares del espacio (...) precisamente definidos para activarlos durante la exposición oral, que es estructurada como un paseo a través de los espacios. (2014, p. 972)

\footnotetext{
${ }^{173}$ Asimismo, y como recupera Schöttker, en su reseña de otro trabajo de Hessel, Spazieren in Berlin, Benjamin dice que el libro es "un eco de aquello que la ciudad narró desde temprano al niño. Un libro completamente épico para el cual el recuerdo no fue la fuente, sino la musa” (Benjamin, citado por Schöttker, 2014, p. 971).
} 
Benjamin mismo trabaja, en sus textos autobiográficos y especialmente en Infancia en Berlín, desplegando el potencial que encierran los recuerdos fijados en imágenes de la ciudad en tanto "imagen especular de la memoria" (Schöttker, 2014, p. 970).

Aun así, ese carácter de topografía de la memoria no es la única cualidad que habita en la compleja trama de la ciudad. Como mencionamos, la sobrecarga de estímulos y shocks que provee la vida urbana provoca un aislamiento que encierra a sus habitantes en el confort del interior (Benjamin, 2008c, p. 232); aislamiento del que el caso de Baudelaire es una clara excepción. Después de todo, “de todas las distintas experiencias que han hecho de su vida aquello en lo que al fin se ha convertido, Baudelaire destaca como la experiencia decisiva, como la sin más inconfundible, ese empujón que le imprime la multitud" (Benjamin, 2008c, p. 259).

Cuando el mundo se aleja, la experiencia se convierte en aquella flor azul a la que se refiere Benjamin en el ensayo sobre la obra de arte, dando lugar a la mera vivencia y a una relación con el mundo en la que la implicación práctica no tiene lugar, vivencia que tan bien ilustra un fragmento de Le goût du néant, de Baudelaire: "Desde lo alto contemplo la redondez del globo, y ya no busco en él de una choza el abrigo" (citado por Benjamin, 2008c, p. 250).

Los ecos de la relación estetizada con el entorno que analizamos en los textos de Simmel en el capítulo 2 y en el mismo Benjamin en el capítulo 3 son evidentes.

A su vez, este diagnóstico del alejamiento del mundo y la necesidad de recuperar la implicación con el entorno trazan líneas de conexión entre la filosofía de Benjamin y la de Heidegger, a la vez que indican algunas tareas para la filosofía, como veremos en la tercera sección de esta investigación. 


\subsection{Consideraciones finales}

Aunque el contexto es de guerra global, no encontrarán en estas crónicas ni pedagogía ni moral. En el cruce no hay dogma.

Paul B. Preciado, 2019, p. 46

Tras habernos concentrado, en el capítulo precedente, en la forma en que Benjamin da cuenta muy agudamente de la crisis de la experiencia que se despliega en su época, en este capítulo intentamos, partiendo de dicho diagnóstico, mostrar cómo el concepto de experiencia que emerge de la filosofía de Benjamin y de los diferentes problemas en los que forma parte es capaz de dejar atrás los anclajes modernos y algunos presupuestos metafísicos que todavía se asocian al término. Dar cuenta de esta redefinición, entonces, lejos de limitarse a una aclaración terminológica resuelta a aclarar posibles malentendidos, resulta relevante para una lectura productiva de Benjamin en tanto "sus reflexiones se inscriben en una lucha semántica en torno a los conceptos, por fijar su uso y por definir nuevamente su significado, en un doble movimiento interpretativo y analítico" (Vargas, 2018, p. 46).

Compartimos, en este sentido, las palabras de Jay:

Entendida en función de la realidad presente y no como un mero residuo del pasado, y beneficiada por la nueva valoración de lo transitorio y lo efímero, la "experiencia" emergió en el umbral de la modernidad al menos como un candidato plausible para ocupar el rol abandonado por los más antiguos y ahora desacreditados fundamentos de legitimidad. (2009, p. 35)

En Benjamin, el hecho de que la experiencia aparezca como una elaboración la aleja decididamente tanto de ser una mera recepción de datos como de funcionar como simple espejo del mundo. También en el ámbito de la historia, y como expone Reyes Mate en su comentario 
a la Tesis VII, "la renuncia a la elaboración del pasado" (2009, p. 132) será la característica principal del método de la empatía del que se aleja Benjamin.

En efecto, Benjamin no diagnostica una crisis en nuestra percepción, sino en la capacidad de articular los acontecimientos que meramente registramos. La experiencia no se tiene pasivamente, sino que se hace activamente: no es del orden de lo contemplativo, sino que es acción, en la medida en que implica una apropiación y una elaboración de la tradición.

A su vez, esta elaboración deberá ser colectiva, en tanto en la constatación de un empobrecimiento de la experiencia en la que nos concentramos en el capítulo 4, lo que se manifiesta en crisis no es la Erlebnis, sino la experiencia en el sentido de Erfahrung, aquella que, excediendo el ámbito personal o privado, resulta comunicable adquiriendo de ese modo, por un lado, un carácter compartido y, por otro, una marcada densidad lingüística.

Finalmente, el modo de redefinir la relación del hombre con el mundo, reconfigurando a su vez, con el eje puesto en la experiencia, los términos de esa relación, abre un camino para repensar aspectos centrales de la filosofía del sujeto y abre diálogos posibles con el pensamiento posthumanista, que pone el eje de la crítica en aquel punto de partida de la filosofía que bien expresa Rosi Braidotti cuando señala que "al principio de todo está Él: el ideal clásico del Hombre" (Braidotti, 2013, p. 13) ${ }^{174}$. De esta manera, el concepto de experiencia que logra delinear Benjamin, como concepto articulatorio que no se aloja ya en el hombre, sino que descentra el análisis del hombre y se sitúa en el umbral poroso en el que se juega su relación con el mundo, es no sólo compatible con los cuestionamientos de la figura de un sujeto fuerte en torno al cual se organiza el mundo, sino que es además productivo para los diálogos filosóficos actuales.

Para finalizar, es importante destacar que, a partir de todos los giros y movimientos a los que nos referimos, la experiencia adquiere no sólo potencialidad filosófica: el rechazo al

${ }^{174}$ Para una reflexión sobre poshumanismo, técnica y experiencia, ver García (2016). 
concepto heredado de experiencia no lleva a Benjamin a replegarse en la interioridad de un pensamiento poetizante, sino que lo impulsa a buscar en lo intersubjetivo, en la acción y en el mundo una ampliación del concepto de experiencia que resulta, en un sentido profundamente benjaminiano, política. 


\section{Tercera sección}

Las posibilidades de la filosofía: contrastes y potencias en tiempos críticos 


\section{Introducción}

No tengo valor para comparecer como profeta ante mis compañeros de la raza humana, y me doblego a su reproche de que yo no puedo ofrecerles ningún consuelo, pues eso es lo que en el fondo exigen todos.

Sigmund Freud, citado por Safranski, 2003, p. 189

En la primera parte de esta investigación nos concentramos en el motivo de la estetización, y analizamos su historia, su rol en el pensamiento de Georg Simmel y su importancia en el entramado complejo que es la filosofía de Walter Benjamin. Como allí atendimos, algunos diagnósticos apresurados posicionan - de manera simplista y muy lejos de cualquier materialismo- algo así como el estado de la cultura o la decadencia de las artes en el lugar de causa de las atrocidades que dan su fisonomía al siglo. No obstante, y como defendimos, la importancia de la relación estetizada del hombre con su entorno, que aparece insistentemente en la filosofía y en el arte, es atendible no como causa, sino acaso como síntoma.

En la segunda parte nos dedicamos a profundizar en la posición de Benjamin, entendiendo que estetización y empobrecimiento de la experiencia son dos manifestaciones de una misma crisis, y que para dar cuenta de dicha crisis hacen falta, en la filosofía, algunos giros y unas cuantas redefiniciones que modifican el modo en que comprendemos la relación del hombre con el mundo. A su vez, analizamos el modo en que, con el doble objetivo de mostrar su crisis y sugerir sus posibilidades, Benjamin redefinió el concepto de experiencia, cuestionando a la vez los sesgos que la tradición había impuesto sobre él.

En esta tercera parte de la investigación nos interesa pensar, sobre la base de este diagnóstico y de las imágenes y conceptos que brinda la obra de Benjamin, cuáles son las tareas 
que afronta la filosofía en tanto productora de sentidos y, más precisamente, en cuanto productora de discurso. Es así que en el último capítulo nos proponemos presentar algunas innovaciones benjaminianas en torno a la escritura, en tanto experimentos que buscan, ya no reflejar una realidad prelingüística dada, sino intervenirla partiendo del propio aparato productivo con el que se trabaja en filosofía. Y es que la pretensión sistemática de la filosofía se revela, en ocasiones, como el intento de fingir un orden en un mundo de caos, de imprimir causalidades simples y taxonomías tranquilizadoras que operan como lentes que ordenan lo dado en manuales y museos. Lentes como aquel que retrató, como examinamos en la primera sección, al nazismo como un movimiento heroico bajo cuya luz las masas danzan, ordenadas y vitales, su hipnótica coreografía.

Ahora bien, Benjamin no fue el único filósofo que detectó estas tendencias del pensamiento en su época. Como reflexiona Rebecca Comay,

[n]o es una mera coincidencia que un año después de que Leni Riefenstahl elevó a un grado exquisito (al mismo tiempo elevó y ocluyó) la pregunta sobre las posibilidades políticas del arte en la era de su reproducción tecnológica, nos encontremos a Heidegger y a Benjamin (por entonces en lados opuestos del Rin) ofreciendo reflexiones paralelas sobre la realidad política de la obra de arte contemporánea. (2010, p. 142)

En efecto, si hacemos foco en "El triunfo de la voluntad" [1935], el film que muestra el congreso del Partido Nacionalsocialista en Nuremberg de 1934, como un hecho artístico y político capaz de hablar por su época, no podemos obviar el hecho de que tanto "La obra de arte en la época de su reproductibilidad técnica" de Benjamin como "El origen de la obra de arte" de Heidegger daten del año $1936^{175}$. Sobre este paralelismo, Comay sostiene que

\footnotetext{
${ }^{175}$ Como repone Arturo Leyte (2016) en el Prólogo a la edición bilingüe del texto, "El origen de la obra de arte" permaneció inédito hasta 1950, cuando fue publicado en Caminos de bosque [Holzwege] y en su versión actual cuenta con un epílogo y un apéndice que fueron añadidos posteriormente. No obstante, su origen se remonta a tres conferencias que dictó Heidegger en los años 1935 y 1936 en Frankfurt y en Freiburg.
} 
"ninguno de los textos es una respuesta al otro, pero en cierto sentido seguramente ambos son una respuesta a la misma cuestión” (2010, p. 142. El enfatizado es nuestro).

En el capítulo 6, por tanto, nos centraremos en la obra de Heidegger e intentaremos dar cuenta de cómo sus escritos pueden relacionarse con los de Benjamin en tanto componen otra lectura de la misma época, que encuentra con la del berlinés, más allá de las diferencias más evidentes, al menos algunas coincidencias atendibles. A su vez y como defenderemos, la filosofía de Heidegger aporta un contrapunto interesante para comprender más cabalmente lo que para Benjamin se pone en juego en la primera mitad del siglo XX.

Nos interesa rescatar la idea que expresa Comay de que la filosofía responde, con su producción, a las cuestiones que le son contemporáneas, en tanto esta implicación con lo que sucede tras los muros de la academia, lejos de poder darse por sentada, es un valor en una disciplina que sabe y supo encontrar la manera de no responder ante nada ni ante nadie. De hecho, el mismo Benjamin hace una referencia que es relevante en este sentido. En el convoluto S de su Obra de los pasajes, anota:

Es fundamental reconocer un momento puntual del desarrollo en su calidad de encrucijada [Scheideweg]. En una de ellas se presenta ahora lo que es el nuevo pensamiento histórico, ese que viene caracterizado por una más elevada concreción, como por su rescate de las épocas de una presupuesta decadencia, por revisar la periodización -en general como en sus detalles-, y cuya futura explotación revolucionaria o reaccionaria se decide ahora justamente [dessen Auswertung in reaktionärem oder revolutionäre(m) Sinne sich jetzt entscheidet]. Pues, en este sentido, en los escritos de los surrealistas, como también en el nuevo libro publicado por Heidegger, se nos anuncia una misma crisis en sus dos posibles soluciones [ein und dieselbe Krise in ihren beiden Lösungsmöglichkeiten]. (Benjamin, 2013, pp. 869-870; GS V 676)

De esta mención, nos interesa subrayar especialmente, más que el mote de reaccionario para Heidegger, que no resulta sorprendente, la identificación del autor de Ser y tiempo como 
un pensador que está dando respuesta a una crisis actual. En algún sentido, tal afirmación, junto a otras del mismo tono crítico presentes en los intercambios epistolares de Benjamin, abonan una lectura de estos dos intelectuales como experimentando y tratando de dar respuesta a un cambio de época, es decir, como filósofos que viven y problematizan una ruptura de la tradición. Como ya mencionamos, tomamos esta expresión de Amengual, Cabot y Vermal, quienes dan cuenta, luego de destacar las conocidas diferencias entre ambos pensadores, de la similitud de sus consideraciones de la necesidad y la exigencia de una tal ruptura: "para Heidegger, a fin de pensar el ser, se requiere saltar fuera de la tradición de la metafísica clásica, como también de la moderna centrada en el sujeto; para Benjamin (...) la memoria es requerida para interrumpir la historia" $(2008$, p. 27).

En efecto, el análisis de la modernidad y la constatación de una ruptura de la tradición es uno de los vasos comunicantes más evidentes entre Benjamin y Heidegger, y si bien no es el único, como exploraremos en el capítulo 6, posiciona a ambos autores como posibles interlocutores en torno a las preguntas con las que queremos concluir esta investigación en el capítulo 7, a saber, ¿cuáles son las posibilidades de la filosofía o, en general, del pensamiento frente al fenómeno de la estetización? ¿cuáles son sus tareas? 


\title{
Capítulo 6
}

\section{La perspectiva de Martin Heidegger}

\begin{abstract}
Volverse contemporáneo de lo que ofrece el estado del mundo no es proceso naturalizable, hay que construir para esto las herramientas adecuadas o reconocerlas. El presente representa no solo la coda de la historia, su último eslabón, el estado de caído sancionado por el viejo esquema teológico de Dios y del hombre. Miseria de lo contemporáneo se dice de muchas maneras.
\end{abstract}

Mariana Dimópulos, 2017, p. 204

\subsection{Introducción}

Este capítulo explora la relación entre algunos aspectos de las filosofías de Benjamin y Heidegger. La inquietud por esta relación nos invita a acercarnos a sus escritos a partir de aquellos lugares de posible contacto entre sus ideas, sin desmerecer las innegables diferencias que signan tanto sus biografías cuanto sus trayectorias filosóficas, y no solo en términos de ideas o filiaciones ideológicas ${ }^{176}$, sino también con respecto a las posibilidades materiales de desarrollar sus carreras: como es sabido, mientras Heidegger escribe desde la comodidad de un puesto académico, Benjamin lo hace desde los márgenes de las instituciones en una situación siempre precaria y siempre cambiante.

Si bien estamos de acuerdo acerca de la importancia de no perder de vista estas diferencias, coincidimos con Caygill (1994, p. 1) en que su consideración puede convertirse, en algunos casos, en un obstáculo para trabajar con ciertos puntos de contacto entre sus filosofías. En este sentido, nos posicionamos críticamente frente a la pretensión de marcar una

\footnotetext{
${ }^{176}$ Ibarlucía resume estas diferencias como sigue: “mientras Heidegger, estudiante católico de teología, dio expresamente su apoyo a Hitler (...), Benjamin (...) fracasó en su intento por lograr un puesto académico, adhirió a la praxis comunista y fue una de las innumerables víctimas del antisemitismo nazi.” (2000, p. 112).
} 
oposición insalvable entre los autores, y fundamentalmente, nos alejamos de todo intento de oponerse por principio al intento de relevar las relaciones que se traman entre sus escritos.

A lo largo de este capítulo intentaremos, entonces, dar cuenta de la posibilidad de entablar un diálogo entre ellos, en la medida en que consideramos que puede resultar fructífero, no sólo para entender las filosofías de ambos a la luz de sus coincidencias y sus oposiciones, sino también para enriquecer, con sus diferentes universos teóricos, los debates acerca de los problemas filosóficos a los que ambos trataron de dar respuesta.

Con este fin explicitaremos, en primer lugar, los puntos de partida de la lectura que proponemos, dando cuenta de los supuestos metodológicos de los que partimos para establecer un diálogo entre los autores y reconstruir algunas de sus posiciones en pos de facilitar dicho diálogo. En segundo lugar, avanzaremos sobre una posible coincidencia entre ellos, a saber, la crítica a la concepción moderna de la relación del hombre con el mundo como una relación articulada por la oposición entre sujeto y objeto, que oculta, olvida o debilita la potencialidad transformadora de la experiencia. En el tercer y cuarto apartados daremos cuenta de cómo esta problematización es observable también, en ambos autores, en el contexto de sus reflexiones sobre el arte y la historia, en el seno de los cuales señalaremos, a su vez, algunas diferencias relevantes, que delimitaremos en las consideraciones finales del capítulo.

Cabe aclarar, asimismo, que nos permitiremos en algún sentido invertir la relación de centro y periferia tal y como estuvo dada históricamente entre los autores. En nuestra investigación, y dado que Benjamin ocupa el lugar central, serán las ideas y conceptos de Heidegger los que se verán en alguna medida forzados a traducirse y adaptarse para entrar en discusión con el marco teórico dado por Benjamin. En este sentido, y si bien a menudo hablar de Heidegger es hablar apelando a su tan característica terminología, este enfoque nos permitirá no someternos al lenguaje técnico del autor. 


\subsection{Una primera aproximación al encuentro}

Sobre su relación histórica, cabe mencionar que, aun cuando fueron contemporáneos, Benjamin y Heidegger no establecieron un diálogo. Más aun, no hubo un medio común en el que un diálogo tal se haya podido desarrollar. En efecto, “dadas sus historias de vida, (...) Benjamin, el judío cosmopolita, y Heidegger, que prefería su choza campesina en el remoto Todtnauberg a la vida en la ciudad, parecen muy dificilmente tener algo en común” (Benjamin y Vardoulakis, 2015, p. xi).

Como es de esperarse dadas las posibilidades materiales de desarrollo de las carreras de ambos filósofos, no hay evidencias de que Heidegger conociera los escritos de Benjamin ${ }^{177}$, pero sí referencias de este último a Heidegger, plasmadas en su correspondencia (fundamentalmente con Scholem y con Gretel Adorno) y en la Obra de los pasajes. En muchas de estas menciones, Benjamin dirige severas críticas a Heidegger, y abona la lectura, más ensayada, de sus filosofías como opuestas. En nuestro caso, intentaremos, sin negar la hostilidad que Benjamin sentía por Heidegger, poner el foco no tanto en las críticas, sino más bien en el carácter de interlocutor que adquiere para el berlinés el autor de Ser y tiempo, que se evidencia también en el fragmento del Passagenwerk al que nos referimos en la introducción a esta sección, en el que Heidegger y los surrealistas aparecen como dos modos opuestos de dar respuesta a una misma situación crítica.

Las menciones de Heidegger en la correspondencia de Benjamin comienzan en 1916 con la crítica a su concepción del tiempo histórico y se prolongan hasta 1938. De todas ellas, dos nos parecen especialmente relevantes. En primer lugar, resulta ineludible la afirmación,

\footnotetext{
177 Si bien este hecho se da por establecido en la mayoría de los estudios, es posible también ponerlo en duda. Richter (2015) se refiere a que "se ha sugerido recientemente, sobre la base de la evidencia encontrada en un no muy conocido texto de Heidegger sobre la Madonna Sixtina de Rafael que fuera publicado en 1955 bajo el título "Über die Sixtina", que él había leído "La obra de arte en la época de su reproductibilidad técnica", cuya tercera versión incluye una larga nota sobre el trabajo de Hubert Grimme sobre la Madonna de Rafael” (p. 30).
} 
presente en una carta a Scholem de abril de 1930, de que con Brecht se proponían “demoler a Heidegger en un grupo muy reducido de lectura crítica" (Wizisla, 2007, p. 85) que ambos dirigirían. Pese a que este proyecto finalmente no se llevó a cabo, da cuenta de que Benjamin mismo no se negó a leer, pensar y criticar a Heidegger. Como menciona Wizisla, junto con Brecht "querían ocuparse de él en la revista Krise und Kritik" (2007, p. 85) en la medida en que "entendían su filosofía como contraproyecto del pensamiento de orientación práctica que ellos privilegiaban" (Wizisla, 2007, p. 85. El enfatizado es nuestro). Otra vez, Heidegger aparece como un contrapunto necesario y no como un opuesto radical.

En un memorándum sobre la revista en cuestión, Benjamin declara sus intenciones. En sus palabras:

La revista tendrá un carácter político. Eso significa en todo caso que su actividad se encuentra anclada en la clara consciencia de la crítica situación de fondo de la sociedad actualmente. Y, además, se sitúa en el terreno de la lucha de clases. Sin embargo, no tiene un carácter político si se toma en sentido partidista. Específicamente, no se trata de una revista proletaria, no es un órgano del proletariado. (2017b, p. 807-808)

La concepción amplia de la política, a la que ya nos referimos en el capítulo 3, se revela central también en el modo de un hacer filosófico que busca posicionarse, enfrentarse y dar respuesta sin convertirse en un órgano de propaganda. "Demoler a Heidegger" es, en este contexto, necesario en tanto la situación de la sociedad es crítica, y en tanto las tareas que se le plantean a la actividad intelectual son experimentadas como urgentes.

La segunda mención que nos interesa destacar aparece en otra carta a Scholem fechada algo más temprano ese mismo año. Allí, Benjamin hace referencia al proyecto de los pasajes, que encarnaría "una teoría de la conciencia de la historia" (citado por Caygill, 1994, p. 2) y escribe: "Es aquí donde encontraré a Heidegger en mi camino, y espero que surjan algunas 
chispas del choque entre nuestras dos maneras muy diferentes de considerar la historia" (citado por Caygill, 1994, p. 2).

La utilización de esta metáfora resulta muy significativa en la medida en que da cuenta de la potencialidad que ofrecía ya para Benjamin pensar la filosofía de Heidegger y la suya propia de forma comparada. En efecto, a partir de esta afirmación creemos que es posible entender el proyecto de Benjamin de leer críticamente a Heidegger no sólo como una estrategia para dar cuenta de los errores, problemas y peligros que presentaba su filosofía $-\mathrm{y}$ en este sentido "demolerlo"-, sino también para delinear algunas de sus propias ideas en discusión con las de Heidegger. Esperar chispas del choque con Heidegger, lejos de una negación de este último como interlocutor, es, creemos, una intuición de la luz que las chispas de un choque semejante pueden echar sobre algunas de las problemáticas filosóficas fundamentales del siglo XX.

Dado el tono crítico evidente en las menciones, y la cercanía, ya suficientemente establecida, de Heidegger con el nazismo (Rockmore, 1992) ${ }^{178}$, algunos autores se han centrado en la imposibilidad de “conciliar” sus filosofías ${ }^{179}$. En esta línea se ubica Löwy, quien rechaza todo punto de contacto y sentencia: "los dos pensadores divergen de manera radical" (2005, p. 16). En nuestro caso, nos interesa aclarar que, muy lejos de conciliarlos, intentaremos el ejercicio de pensar sus filosofías como respuestas a una misma época, que tienen por eso mucho en común, aun cuando pueda sostenerse que, en sus intenciones y sus convicciones más profundas, los pensadores divergen efectivamente de manera radical.

\footnotetext{
${ }^{178} \mathrm{Si}$ bien la filiación puede darse por establecida, fundamentalmente tras la publicación de los Cuadernos Negros [Schwarze Hefte 1938-1939] (Heidegger, 2017), que incluyen contenido abiertamente antisemita, el carácter y la intensidad del compromiso de Heidegger con el nazismo, y fundamentalmente la relación que este compromiso guarda con sus ideas, es aún tema de profundos debates. Véase, por ejemplo, Young (1997), Farías (1998), Lyotard (1995).

${ }^{179}$ Para algunos autores, incluso, el conocimiento de la filiación de Heidegger con el nazismo debería tener como consecuencia su total ostracismo de la filosofía. En esta línea, Emmanuel Faye (2019) sostuvo que "admitir la obra de Heidegger como una fuente de pensamiento es algo especialmente peligroso" (p. 709).
} 
Entre quienes realizan un ejercicio como el que proponemos quizá la primera haya sido Hannah Arendt (Benjamin y Vardoulakis, 2015, p. xi) cuando, polémica, afirmó:

Sin darse cuenta, Benjamín tenía en realidad más en común con el notable sentido de Heidegger para los ojos vivos y los huesos vivos que el mar había transformado en perlas y coral (...), de lo que lo hizo con las sutilidades dialécticas de sus amigos marxistas. (Arendt, 1990, p. 186)

Asimismo, en la recepción actual de Benjamin y Heidegger es posible encontrar una serie de trabajos que se esfuerzan por explotar el potencial de un encuentro. Rebecca Comay, quien organiza este encuentro en torno a los escritos de ambos autores sobre la obra de arte, alertando acerca de los riesgos de una oposición apresurada, afirma:

No quiero que la discusión, al menos no desde el comienzo, quede determinada por la fuerte matriz de oposiciones que sin lugar a dudas también gobierna este nointercambio en su dimensión biográfica: campo versus ciudad, Friburgo versus París, hogar versus extranjero, alemán versus judío, “inmigración interna” versus exilio, y se podría seguir. (2010, p. 143)

En el mismo sentido, Caygill, en el marco de su estudio acerca de la relación entre ambos en torno a la tradición y el tiempo histórico, señala la importancia de "no abrir una brecha entre estos dos pensadores, sino leerlos juntos, contrastando sus ideas" (1994, p. 30).

Asimismo, entre los intentos de encontrar las condiciones de posibilidad de un encuentro es importante mencionar el volumen colectivo Sparks will fly (2015), que, escapando de la búsqueda de coincidencias y diferencias aisladas, logra hacer hincapié en la productividad que un diálogo -mayormente póstumo- entre estos pensadores puede tener para nuestro presente, llevando a cabo un esfuerzo colectivo y sostenido por acercar sus ideas. Sin embargo, y vale la pena enfatizar este mérito, acercar no será aquí señalar similitudes ni conciliar, sino que significará una jugada mucho más arriesgada: poner a estos dos grandes de la filosofía, a 
su manera revolucionarios (Benjamin para la tradición ligada al marxismo, Heidegger para la fenomenología y la hermenéutica), a discutir frente a frente, "dando cuenta de las continuidades tanto como de las discontinuidades entre las ideas de los dos pensadores“ (Benjamin y Vardoulakis, 2015, xii). Y como es esperable, para que este encuentro tenga lugar hace falta realizar, en primer lugar, el ejercicio de delimitar -o fundar- un espacio de diálogo y discusión, o varios.

Siendo que intentaremos algo similar, aunque a una escala menor, nos interesa recuperar el concepto de "campo o espacio controversial" desarrollado por Nudler (2004), en tanto posibilita describir más precisamente la operación que proponemos realizar: dar cuenta, sin reducirlas, de las continuidades y discontinuidades que es posible encontrar entre Benjamin y Heidegger en torno a algunos problemas concretos. Un campo controversial, siguiendo a Nudler, contiene tanto problemas que están en el foco de las controversias como presupuestos -explícitos o implícitos- que están fuera de la controversia y definen un suelo común. Dicho suelo no puede ser vacío, puesto que, si así fuera, "la posibilidad misma de existencia del espacio controversial desaparecería" (Nudler, 2004, p. 12) ${ }^{180}$.

En este sentido, el suelo común en el que nos interesa poner a dialogar a estos autores es fundamentalmente el de la crítica de la tradición en tanto ambos, al desarmar partes del andamiaje filosófico heredado, dan lugar a nuevas formas de comprensión y conceptualización de la experiencia ${ }^{181}$. En alguna medida y como veremos a lo largo del capítulo, es posible pensar que Benjamin y Heidegger vieron los mismos problemas y pensaron en soluciones bien

\footnotetext{
${ }^{180}$ Martin Jay utiliza, en un sentido similar, el concepto de "campo de fuerzas", que toma de la idea benjaminiana de Kraftfeld presente en el convoluto N de la Obra de los pasajes. En Benjamin, el campo de fuerzas se da entre el pasado y el presente. Adorno, quien retoma la idea, la usa según Jay para "sugerir una yuxtaposición no totalizadora de elementos cambiantes, un interjuego dinámico de atracciones y aversiones, que no tienen un principio generador primario, ni un denominador común, ni una esencia inherente” (Jay, 2003, p. 14).

${ }^{181}$ Zimmerman sostuvo que "como Kant, Heidegger creía que la tarea del filósofo era descubrir las condiciones trascendentales que hacen posible el conocimiento y la acción humanos. Esas condiciones no son ellas mismas cosas, sino que hacen posible nuestra experiencia objetiva de las cosas" (1990, p. xiv. Enfatizado en el original).
} 
diferentes. Sin embargo, como también desarrollaremos, el diagnóstico tiene en cada caso un tono propio que adelanta la respuesta que será propuesta como tarea.

Entre los pensadores que se han esforzado por explicitar un espacio semejante cabe mencionar también a Peter Fenves, quien a su vez reconstruye un encuentro real entre los autores. Como recupera el autor, Benjamin y Heidegger se habrían encontrado de hecho en 1913 en el marco de un seminario a cargo de Heinrich Rickert que exploraba la diferencia entre la mera vida [bare life, bloßes Leben] y la vida completa o llena [completed life, vollendetes Leben $]^{182}$. El punto de partida del autor es claro: no busca influencias de un autor sobre el otro, sino que describe la relación a partir de una serie de puntos de correlación que muestran la proximidad de sus líneas de pensamiento -como partes de un mismo entramado, de un cierto sistema-, tanto como la divergencia del sentido y la dirección en que estas líneas se mueven. A partir de la coincidencia en el seminario, el diálogo con Rickert se hace patente, según Fenves, en la adaptación de la terminología, en la elección de los temas y, centralmente, en el rechazo que ambos elaboran y el desmantelamiento que operan en la década del 20 del concepto mismo de vida completa en el marco del campo de tensiones que éste forma con el nihilismo nietzscheano. Fenves hace hincapié, en su estudio, en la importancia que en ambos adquiere la crítica a la teoría del conocimiento como punto de partida para repensar al sujeto y para problematizar la experiencia.

Como puede observarse, varios son los autores que han señalado una coincidencia relevante entre Benjamin y Heidegger, y dicha coincidencia tiene que ver, en general, con el modo en que estos filósofos se han atrevido a repensar la relación del hombre con el mundo de manera radical, operando a su paso destrucciones significativas en la estructura tradicional del

\footnotetext{
${ }^{182}$ Sobre la influencia de Rickert en Heidegger puede consultarse Safranski (2003, p. 75 y ss). Asimismo, sobre la influencia que dicho seminario tuvo en los jóvenes Benjamin y Heidegger, ver Naishtat (2017b, p. 7 y ss). A su vez, Naishtat repone en dicho texto parte del contenido del seminario de Rickert, y da cuenta de cómo tanto el seminario como la lectura de Kierkegaard y, algunos años más tarde, el contacto con Scholem, constituyen todas piezas que ayudan a comprender mejor el mesianismo benjaminiano y su relación con la concepción del tiempo que Benjamin despliega ya en las Tesis.
} 
saber filosófico, entre las cuales la crítica a la noción de sujeto y a la conceptualización del mundo como el mero escenario mudo de nuestras vivencias resultan centrales, como tuvimos oportunidad de detallar en el caso de Benjamin y como veremos en el caso de Heidegger. La problematización de la experiencia que opera este autor será entonces, en nuestro recorrido, el punto de partida, en el que nos centraremos en el próximo apartado.

Antes de empezar a delinear el modo en que Heidegger puede entrar en diálogo con Benjamin en torno a la redefinición de la experiencia, nos interesa destacar una última reflexión metodológica. En un texto sobre estos dos autores, Gerhard Richter se pregunta qué significa “comparar" a dos filósofos con enfoques y terminologías tan singulares que tienen perspectivas radicalmente diferentes y reflexiona acerca de que "la comparación es vulnerable a la arbitrariedad, al agotamiento y al aburrimiento, porque cualquier cosa puede ser comparada con cualquier otra" $(2015$, p. 28$)$. En este sentido, cabe preguntarse: ¿deberíamos limitarnos a estudiar cada obra en sí misma, cada universo teórico en sí mismo, cada autor en sí mismo? Coincidimos con la respuesta del mismo Richter: por arbitraria o aburrida que pueda ser la comparación, es sin embargo en ella donde aflora más propiamente la especificidad de un pensamiento o el aporte que significa una idea original. Aun así, lo cierto es que la comparación no tendría tanta relevancia si no se basara en la convicción de que los autores tienen una afinidad; afinidad que, en este caso, por ser conflictiva y plagada de tensiones abre sentidos que afinidades más directas - como la de Benjamin con Adorno, Brecht o Scholem- no son capaces de iluminar ${ }^{183}$. Y es que, en palabras de Richter, "Benjamin y Heidegger comparten un conjunto fundamental de preocupaciones" (2015, p. 30). El acercamiento que proponemos intenta iluminar ese conjunto de preocupaciones, dar con la definición que cada pensador

\footnotetext{
${ }^{183}$ En este sentido, resulta interesante también la exploración de la recepción de Heidegger entre autores de la escuela de Frankfurt afines a Benjamin. En Toward a Concrete Philosophy: Heidegger and the Emergence of the Frankfurt School (2020), Mikko Immanen investiga justamente las interpretaciones que ofrecen Adorno, Horkheimer y Marcuse sobre la obra de Heidegger, fundamentalmente antes de 1933.
} 
elabora de la época - o del mundo- que comparten, y buscar pistas acerca de las tareas que le plantean al hombre y a la filosofía.

En el texto al que nos referimos anteriormente, en el que narra el encuentro en el seminario de Rickert, Fenves hace uso de una imagen importada de la mecánica cuántica para hacer referencia a la relación entre los autores: se trata del "entrelazamiento" [entanglement ${ }^{184}$ ] de "partículas cargadas que explotan al contacto una con otra" (2015, p. 4). En la línea de aquella imagen de la que se vale el propio Benjamin del choque generador de chispas, Fenves habla de entrelazamiento para dar cuenta de que Heidegger y Benjamin tienen puntos de contacto muy próximos, pero que sus ideas salen disparadas, partiendo de esos cruces, en direcciones y sentidos opuestos.

\subsection{La relación del hombre con el mundo: la importancia del cuidado}

En el pensamiento moderno, la división cartesiana de las sustancias en dos especies, sustancia pensante y sustancia extensa, suministra el ejemplo más contundente de la renuencia a considerar aún como problemático el propio lugar del "encuentro".

Peter Sloterdijk, 2011, p. 265

En esta sección nos centraremos en la primera de estas encrucijadas de caminos, preguntándonos si es posible leer en la filosofía de Heidegger, y fundamentalmente en Ser y

\footnotetext{
${ }^{184}$ Como expone Fenves, tanto Heidegger como Benjamin utilizan la versión alemana de este término (Verschränkung) en la década del 30: Heidegger en "Introducción a la metafísica", Benjamin en la primera versión de su ensayo sobre la obra de arte (Fenves, 2015, pp. 16-17). Naishtat da cuenta, siguiendo a Fenves, de que "esta palabra tiene una segunda vida científica y epistemológica en el vocabulario del físico austríaco de la mecánica cuántica Erwin Schrödinger, quien en 1935 la usa en una correspondencia dirigida a Albert Einstein, para hablar del carácter de dos cuerpos que de alguna forma permanecen en comunicación el uno con el otro, sin importar cuán lejanos pudieran estar el uno del otro, es decir, de dos cuerpos, tales que habiendo interactuado una vez, permanecen en cierta forma vinculados sin importar la distancia. Schrödinger menciona el verbo verschränken también a propósito de su célebre experimento mental llamado "el gato de Schrödinger" en un artículo cuyo nombre es Die gegenwärtige Situation in Quantum Mechanik de 1935. Lo importante de la Verschränkung es que entre los elementos entrecruzados, pongamos, A y B hay una relación pero ninguna causa común entre los mismos" (2017b, pp. 3-4).
} 
tiempo, un diagnóstico similar al que ofrece Benjamin en 1933, a saber, que nuestra experiencia se encuentra en crisis. Andrew Benjamin sostiene que es justamente la centralidad dada a la experiencia lo que hace necesario indagar la relación entre Heidegger y Benjamin (1994, p. 220), y en este mismo sentido, Martin Jay sostiene que compartían tendencias similares en torno a la cuestión de la experiencia. En sus palabras:

ambos se mostraban hostiles a privilegiar la Erlebnis, ambos se oponían a reducir la experiencia a una categoría epistemológica como Kant o los empiristas, y ambos deseaban trascender el subjetivismo moderno y restituir una noción de experiencia previa a la escisión entre el sujeto y el objeto. (2009, p. 396)

De hecho, Jay utiliza la expresión "experiencia sin un sujeto" (2009, p. 144) para referirse al intento de reelaboración del concepto de experiencia que llevan a cabo tanto Heidegger en Ser y Tiempo como Benjamin en algunos escritos de los años $30^{185}$. En efecto, ambos tratan de superar la concepción de la experiencia propia de la modernidad, y lo hacen elaborando una nueva conceptualización de la relación del hombre con el mundo que no la defina en términos de la relación cognoscitiva entre un sujeto y un objeto. En el caso de Benjamin y como vimos fundamentalmente en el capítulo 5, la Erfahrung, a partir de la pregunta radical por su misma posibilidad tras la crisis de sus soportes y formas tradicionales, adquiere una espesura nueva y se convierte en un concepto articulatorio que potencia la redefinición del hombre y del mundo. En el caso de Heidegger, la nueva comprensión de la

\footnotetext{
${ }^{185}$ En "Una experiencia sin sujeto: Proust entre Benjamin y Heidegger", Melamed (2012) retoma la fórmula de Jay y sostiene que en la novela proustiana es posible encontrar ya desde el inicio la exposición de una experiencia de este tipo. En palabras de la autora: "En el comienzo de la novela proustiana, un individuo sin rostro, a medias despierto, se pregunta qué hora es y en qué cama está. En ese instante del despertar hay un yo que para saber quién es debe leerse en el cuarto en el que se encuentra, en la ubicación de los muebles, en la luz que se filtra por la puerta, en la disposición del cuerpo en la cama. No hay trama, no hay aventura, solamente un estado de la conciencia, un entre dos, que se mantiene hasta el final. El espacio de la novela se despliega a partir de esa experiencia primera y primaria. Es allí también donde el texto literario se convierte en expresión de aquellas ideas a las que algunos lenguajes filosóficos apuntan, pero no alcanzan a decir" $(2012$, p. 1). Volveremos sobre la problematización de las formas de exposición de la filosofía y del arte, que también aborda Melamed en el texto, en el próximo capítulo.
} 
experiencia humana parte del rechazo de los términos tradicionales y desemboca en la construcción de un universo teórico y terminológico propio en el que el autor trabajará toda su vida, no tanto para perfeccionarlo, sino operando giros y rodeos y tomando caminos nuevos.

En este sentido, aun cuando Heidegger realiza importantes desplazamientos respecto de la obra de su maestro, la influencia de Husserl se hace notar como punto de partida de la indagación, que Jesús Adrián Escudero resume como sigue:

¿cómo es posible aprehender genuinamente el fenómeno de la vida sin hacer uso del instrumental tendencialmente objetivante de la tradición filosófica? La respuesta es tajante: hay que suspender la primacía de la actitud teórica y poner entre paréntesis el ideal dominante de las ciencias físicas y matemáticas que impregna el quehacer filosófico desde Descartes hasta Husserl. (2010, p. 17)

Nos interesa destacar en este punto su posición justamente en la medida en que, sin ocuparse de Benjamin, describe la filosofía de Heidegger de un modo tal que la acerca mucho a las intenciones y preocupaciones del berlinés. Y es que, en la interpretación del autor, "Ser y tiempo no elabora una teoría filosófica entre otras, sino que afronta el reto de pensar a fondo la crisis en la que se encuentra la filosofía tradicional" (2012, p. 74), y

lo hace de una manera peculiar, haciendo confluir (...) las inquietudes fundamentales de la época contemporánea: el desencantamiento del mundo moderno, la crisis de los valores tradicionales, el declive de la metafísica, la huida de los dioses, el dominio de la técnica, la hegemonía de la racionalidad instrumental y la búsqueda de nuevos recursos simbólicos para el hombre. En este sentido, Ser y tiempo se convierte en un preciso sismógrafo capaz de detectar con sorprendente precisión los corrimientos y las fallas de la era contemporánea. (Escudero, 2012, pp. 74-75)

Esta descripción, que no se limita a Ser y tiempo, sino que abarca más ampliamente la producción de Heidegger, podría aplicarse a "Experiencia y pobreza", en tanto el diagnóstico 
de una ruptura de la tradición ya en curso, al que nos referimos, y a su vez la intención de asumir esa crisis y poner en marcha un movimiento de destrucción ${ }^{186}$ en tanto aquello que está en crisis es a la vez objeto de críticas profundas, son características de ambos diagnósticos. En su lectura del texto benjaminiano, Burkhardt Lindner da cuenta de cómo este y otros textos del mismo período tienen como trasfondo un contexto de profunda crisis, y de cómo en Benjamin la tematización de la tradición es no sólo contemporánea sino también complementaria con la de la destrucción (Lindner, 2011, p. 451). Lejos de tratarse de una casualidad, de lo que estamos en presencia es de un síntoma de época ${ }^{187}$ que, de todos modos, lejos de presentarse como un trasfondo dado, exige sensibilidad percibir, y voluntad intelectual asumir. Este punto de contacto da cuenta de la potencialidad que tiene pensar las filosofías de Benjamin y de Heidegger entrelazándolas, en tanto ambas pueden ayudarnos a imaginar modos posibles de pensar la experiencia que desarticulen los esquemas tradicionales que pesan desde el pasado.

Es bien sabido que el objeto explícitamente enunciado de análisis de Ser y tiempo no es la existencia humana, sino el ser (Pöggeler, 1993, p. 21), y que el análisis del Dasein sólo opera, en teoría, como vía para llegar al ser, para dar con él, en la medida en que al Dasein o ser-ahí “le va en su ser este mismo ser [in seinem Sein um dieses Sein selbst geht]" (Heidegger, 2006, p. 35; SuZ 12. Enfatizado en el original).

Aun así, el ser del existente humano, su cotidianidad, su trato con el mundo, acaban siendo tópicos centrales de Ser y tiempo (Morgan, 2012), a un punto tal que se torna discutible cuál sea el aporte más relevante del libro, y, en general, del autor, más allá de las intenciones que hayan motivado la escritura y de los objetivos que explícitamente se haya fijado la

\footnotetext{
${ }^{186}$ Como repone Greisch, la destrucción es relevante en el método heideggeriano, fundamentalmente en tanto "significa la deconstrucción crítica de los conceptos recibidos de la tradición" (2010, p. 98).

${ }^{187}$ La definición concreta de cuál es el problema de la época es, en este contexto, muy relevante. En su lectura, Escudero se refiere al "clima de desasosiego intelectual, de inhospitalidad existencial y de desazón espiritual de una época dominada por el ocaso de los héroes. Encontramos múltiples retratos de una sociedad fragmentada y falta de ídolos en obras coetáneas como El hombre sin atributos, de Robert Musil, La montaña mágica, de Thomas Mann, Ulises, de James Joyce, La metamorfosis, de Franz Kafka, y, de una manera muy gráfica, en El grito, de Edvard Munch, y en la película El gabinete del Dr. Caligari, de Robert Wiene." (2012, p. 75). Daremos cuenta de las diferencias entre el diagnóstico heideggeriano y el benjaminiano sobre el final del capítulo.
} 
investigación ${ }^{188}$. En efecto, esta discusión arroja respuestas como la de Escudero, para quien "se puede afirmar que Ser y tiempo no es tanto un tratado de filosofía abstracta como un libro de filosofía práctica” (2010, p. 2), o la de Volpi (1994; 2009; 2012), cuya interpretación en alguna medida reafirma esta idea poniendo a esta obra en relación directa con los análisis de la ética aristotélica presentes en el Informe Natorp ${ }^{189}$.

Tanto en torno a la pregunta por el ser como en torno al análisis de la existencia humana, uno de los puntos de partida de Ser y tiempo es la demoledora crítica a la tradición filosófica por el primado que en ella adquiere la actitud cognoscitiva del hombre por sobre otros modos de relacionarse con el mundo. Frente a esta idea, Heidegger postula como actitud primaria del Dasein la de estar en medio del mundo ocupándose ya siempre de él. En efecto, la existencia humana será comprendida como un estar-en-el-mundo $[\text { In-der-Welt-sein }]^{190}$, y la relación de esa existencia humana con ese mundo en el que ya siempre está y con el que ya siempre lidia será entendida como una relación de implicación y de compromiso que Heidegger llamará “cuidado" [Sorge $]^{191}$.

\footnotetext{
188 Pöggeler (1993) da cuenta de que la orientación hacia la vida fáctica no supone un abandono de la pregunta por el ser, sino una forma de indagación a partir de esta pregunta que se retira de las especulaciones tradicionales de la metafísica y hace otro camino (p. 55).

${ }^{189}$ Se trata del texto "Interpretaciones fenomenológicas sobre Aristóteles. Información sobre la situación hermenéutica", texto que Heidegger escribió entre septiembre y octubre de 1922, basado en los cursos sobre Aristóteles que dictaba en Friburgo, y que envió a Paul Natorp para obtener un cargo como profesor en la Universidad de Marburgo. La respuesta de Natorp, que leyó el texto con Nicolai Hartmann, fue muy positiva, y Heidegger obtuvo la plaza en 1923.

${ }^{190}$ Acerca del modo de escribir esta expresión, y como aclara Escudero, los guiones "resaltan precisamente esa originaria copertenencia de Dasein y mundo. Con ello se rompe definitivamente con el modelo de la filosofía de la conciencia que piensa el yo como un solus ipse y se supera la dicotomía moderna entre res cogitans y res extensa, sujeto y objeto" (2015, p. 127). A su vez, Safranski recuerda estas palabras de Heidegger sobre su manera de escribir: "Si nos vemos aquí obligados a introducir palabras pesadas y que quizá no resulten bonitas, eso no se debe a un capricho mío, ni se basa en una afición especial a una determinada terminología, sino que responde a las exigencias de los fenómenos mismos" (2003, p. 191).

${ }^{191}$ Para Pöggeler, este punto de partida tiene un cierto origen, en Heidegger, en sus investigaciones sobre el cristianismo primitivo. En sus palabras: "Gracias a la meditación sobre la religiosidad del cristianismo primitivo como modelo de la experiencia fáctica de la vida adquiere Heidegger los conceptos rectores que ponen de relieve la estructura de la vida fáctica o, como dirá más tarde, de la 'existencia fáctica" (1993, p. 45). En efecto, Heidegger se refiere ya en su su curso de Friburgo del semestre de invierno de 1920-21 (Introducción a la fenomenología de la religión [Einleitung in die Phänomenologie der Religion) a esa experiencia fáctica de la vida que se encuentra formulada en las Epístolas de San Pablo. La investigación sobre el cristianismo primitivo, a su vez, es una de las fuentes que nutren su pensar sobre la historia. Sobre la importancia del cristianismo en la formación de algunas de las ideas de Heidegger, y fundamentalmente sobre el modo en que dicho influjo moldea tensiones interesantes con Benjamin, puede consultarse Viglione (2018).
} 
Con este concepto, Heidegger apunta a recuperar lo más originario de la relación del Dasein respecto a un mundo en el que ya siempre está y que siempre comprende, en tanto el cuidado es una condición originaria que relaciona al existente humano con los entes intramundanos -en la ocupación [Besorgen]- y con los otros Dasein -en la solicitud [Fürsorge]-. Esta constelación de conceptos sitúa al existente humano en el entramado de su relación con el mundo, evitando pensarlo en primer lugar como una suerte de isla que sólo en segundo lugar puede establecer relaciones con aquello que lo rodea. Asimismo, el cuidado y el estar-en-el-mundo funcionan como conceptos articulatorios, en tanto evitan partir de la figura de un sujeto para pensar la experiencia. Como sostiene Safranski, para Heidegger

hay que comenzar por el "Ser-en". Pues "fenoménicamente" ni me experimento primero a mí mismo y luego experimento el mundo, ni, a la inversa, experimento primero el mundo y luego me experimento a mí mismo, sino que en la experiencia están dadas ambas cosas a la vez en unión indisoluble. Esta experiencia recibió en la fenomenología el nombre de “intencionalidad”. Según Heidegger, ahí está la intuición fundamental de la fenomenología, que él, por su parte, entiende como la relación del ser-ahí con el mundo, y no sólo, a diferencia de Husserl, como estructura de la conciencia. (2003, p. 190)

La noción de cuidado sitúa al hombre en el entramado de su relación con el mundo, y reafirma que “el Dasein no es jamás 'primeramente' un ente, por así decirlo, desprovisto de estar-en [ein gleichsam in-seins-freies Seiendes], al que de vez en cuando le viniera en ganas establecer una 'relación' con el mundo" [die Laune hat, eine 'Beziehung' zur Welt aufzunehmen] (Heidegger, 2006, p. 83; SuZ 57) ${ }^{192}$.

\footnotetext{
${ }^{192}$ Escudero, por ejemplo, sostiene que "Ser y tiempo puede leerse en el marco de una larga tradición del cuidado de sí, inaugurada por Platón, practicada por las diferentes escuelas helenísticas, luego olvidada por la filosofía de la época escolástica y, finalmente, recuperada por autores como Michel de Montaigne, Blaise Pascal, Arthur Schopenhauer y Friedrich Nietzsche, la cual alcanza su máxima expresión contemporánea en la ética del cuidado de Michel Foucault" (2012, p. 76).
} 
De la misma manera que, tal y como tuvimos oportunidad de exponer, la redefinición del concepto de experiencia (como Erfahrung) se convierte, en el entramado conceptual benjaminiano, en la forma de deshacerse de las concepciones heredadas, el concepto de cuidado se convierte, en Ser y tiempo, en una herramienta para objetar a la tradición de la metafísica occidental: si Heidegger está en lo cierto acerca de que esa es la estructura fundamental y originaria del estar en el mundo, entonces debemos rechazar como falsa la afirmación de que el afán de conocimiento, o de dominio, es el que estructura nuestra relación con él.

Asimismo, y al redefinir la relación entre el Dasein y el mundo, el concepto de cuidado ayuda a disolver ciertos mitos acerca de lo que el hombre y el mundo son en sí mismos: para Heidegger, lejos de ser dos entes en oposición, el Dasein y el mundo no pueden pensarse por fuera de la relación que les da sentido. Otorgando centralidad entonces a los conceptos de estaren-el-mundo y de cuidado, podemos pensar a Heidegger como un autor que redefine la experiencia en el sentido esbozado por Jay de una experiencia sin sujeto, ya que diluye la noción de sujeto en la estructura unitaria del estar en el mundo, a partir de la cual la existencia humana, al no estar escindida del mundo, no debe salir de sí para generar un encuentro con él. Como mencionamos, en esta gran reelaboración conceptual que lleva a cabo Heidegger para escapar de los marcos de la metafísica moderna es importante su recuperación de algunos postulados de la ética aristotélica. Detengámonos brevemente en esta fuente de la filosofía heideggeriana.

En efecto, con la filosofía práctica de Aristóteles “se abre una vía de escape que permite salir del callejón sin salida de la filosofía de la conciencia ${ }^{193 "}$ (Escudero, 2002, p. 18) ${ }^{194}$.

\footnotetext{
${ }^{193} \mathrm{Al}$ respecto sostiene Safranski: "la filosofía hasta ahora ha pecado en cierto modo. Ha descrito o bien cómo la conciencia surge a partir del mundo (naturalismo), o bien cómo el mundo queda constituido por la conciencia (idealismo). Heidegger busca un tercer camino" (2003, p. 190).

${ }^{194}$ Pöggeler ha sostenido que, "en el mejor de los casos, Heidegger puede llevar al lector al camino por el que él ha avanzado ya un trecho, provocando (...) un 'dejar crecer" (1993, p. 14). De la misma manera, se puede pensar que Aristóteles también señala, para Heidegger, un camino, teniendo en cuenta que "Heidegger siempre ha entendido su pensar como un caminar, como un estar en camino" (Pöggeler, 1993, p. 11).
} 
Heidegger toma esa vía, aun cuando encuentre el fin de la misma y continúe su camino por un sendero no señalado aún en el que él mismo se abre paso y por el cual, para algunos, se pierde $\left(\right.$ Volpi, 2008) ${ }^{195}$.

La modernidad, podría pensarse, ha acudido a los textos griegos con sus propios prejuicios, como si quisiera encontrar en ellos cómplices de sus propias concepciones, y Heidegger tiene la intención de

asumir la tarea de deshacer el estado de interpretación heredado y dominante, de poner de manifiesto los motivos ocultos, de destapar las tendencias y las vías de interpretación no siempre explicitadas y de remontarse a las fuentes originarias que motivan toda explicación por medio de una estrategia de desmontaje. (Heidegger, 2002, p. 51)

Aristóteles aparece como una fuente, aún fructífera, de una tradición que ha olvidado o simplemente desconoce el sentido originario de los conceptos que la fundan. Uno de los textos de los que se vale Heidegger en su reapropiación de la filosofía aristotélica es la Ética a Nicómaco: una investigación, en clave ética, del comportamiento humano en relación fundamentalmente con los otros. Heidegger, como él mismo explicita en sus Interpretaciones fenomenológicas sobre Aristóteles [Informe Natorp] ${ }^{196}$, de 1922, prescindirá en su análisis de la problemática específicamente ética (2002, p. 60) y se centrará en aquello que el filósofo griego puede decirnos sobre la condición humana en general. Este giro interpretativo, eje principal que vertebra toda la investigación, implica una ontologización de la filosofía práctica de Aristóteles que pone en duda la escisión entre metafísica y ética, o entre filosofía teórica y filosofía práctica, cuestionando también en el mismo movimiento la también tradicional

\footnotetext{
195 Volpi, quizá quien más haya estudiado la compleja relación que nos ocupa $(1994,2009,2012)$, termina alejándose de Heidegger (Volpi, 2008) y optando por reivindicar a Aristóteles (Berti, 2012).

${ }^{196}$ Allí cristaliza la interpretación heideggeriana de Aristóteles, luego de ser trabajada en varios de los cursos que el joven Heidegger dictó en Friburgo.
} 
preferencia por el tratamiento de la especulación teórica en detrimento de la esfera de la praxis como objeto de estudio de la filosofía.

Heidegger está, ya en 1922, convencido de que el mundo en que el hombre vive y actúa no es para él un mero objeto de contemplación, lo que significa que no es, o al menos no originariamente, un objeto de conocimiento. En sus palabras:

El ámbito de objetos que presta el sentido originario del ser es el de los objetos producidos, el de los útiles empleados en el trato cotidiano [con el mundo]. Así, pues, el horizonte al que tiende la experiencia originaria del ser no se asienta en el ámbito ontológico de las cosas concebidas a la manera de un objeto que se aprehende teoréticamente en su contenido real, sino que comparece en el trato de la producción, de la ejecución y del uso de los objetos producidos. Aquello que ha sido finalizado en la actividad del trato productivo (póiesis), aquello que está a la mano y disponible para una eventual utilización: esto es lo que propiamente es. (2002, p. 57)

La actitud teórica, como se expone en este Informe y como se desarrolla a lo largo de todo Ser y tiempo, no es concebida como la actitud principal del hombre, sino sólo como una actitud derivada que depende, además, de la suspensión de la que sí resulta la actitud primaria del Dasein, a saber, el cuidado [Sorge]. Este concepto, en cuanto indica el modo práctico en el que hombre se vincula con el mundo, se relaciona con la esfera aristotélica de la praxis, con la diferencia de que Aristóteles plantea la praxis como una de las tres actividades de la vida humana, junto con la póiesis y la theoría, mientras que Heidegger concibe al cuidado como una especie de zócalo constitutivo del existente humano a partir del cual se desarrollan todas sus actitudes ${ }^{197}$.

\footnotetext{
${ }^{197}$ Otro de los ejes de la lectura heideggeriana de Aristóteles es su peculiar apropiación del concepto de phrónesis. Heidegger mismo se refiere a su interpretación diciendo que "facilita una primera comprensión del carácter ontológico inherente a la phrónesis misma" (2002, p. 70). La phrónesis, como capacidad que se explicita en el actuar del hombre, no depende ya del conocimiento teórico, sino que tiene su propia esfera de racionalidad: no es una ciencia reglada con conexiones causales fijas, sino un lugar de la vida concreta en que el conocimiento que el
} 
Heidegger distingue entre el trato ejecutivo, de tipo instrumental y pragmático, donde el conocimiento que opera es el del hacer (el saber práctico), y el trato de tipo científico, de observación y objetivación del mundo, y ensaya la teoría de que este último sólo puede surgir cuando se necesita, para fines prácticos y cotidianos, de un mayor conocimiento en algún área. Es allí, sólo por medio de esta necesidad, que aparece en la dinámica de la vida del hombre la actitud teorética. En la observación, el hombre suspende su comportamiento originario de trato con el mundo y, mediante la suspensión de la actividad del cuidado, convierte a ese mundo, originariamente su medio, en un objeto que se le opone ${ }^{198}$.

Como veremos en la próxima sección de este capítulo, la preocupación por el olvido de la forma originaria de trato con el mundo, y la prelación que adquiere en la modernidad la comprensión de esa relación en términos de una relación entre un sujeto y un objeto, es un motivo central en la filosofía de Heidegger que lo acompaña tanto en la construcción de Ser y tiempo como en la interpretación de otros autores, en quienes busca, como en el caso de Aristóteles, pistas que permitan repensar nuestro trato con el mundo de un modo más apropiado. A su vez, esta preocupación es uno de los legados de la filosofía de Heidegger, en tanto inspira la intensa, compleja y polémica búsqueda que constituye su carrera y lo pone en diálogo con autores de su época y de la nuestra.

Entre los últimos, y trazando ya desde la inscripción institucional un cierto puente hacia Benjamin, Honneth ${ }^{199}$ se ocupa del concepto heideggeriano de Sorge, y propone entenderlo justamente como una respuesta a la pregunta acerca de cuál sería una relación no reificada con el mundo. Honneth (2007) define la reificación como un olvido de la forma originaria de la

hombre tiene del mundo por su trato con él juega un papel fundamental como un saber legítimo y valorado. Su lógica propia se aprecia en los casos concretos, en los phrónimos y en las acciones virtuosas mismas.

${ }^{198}$ La palabra sophía, explica el filósofo sustentando esta idea, nace en el uso del término comparativo sophóteron, empleado justamente para indicar la necesidad de saber más acerca de algún fenómeno y de observar, entonces, más agudamente. Lo que lleva a la sabiduría teórica es en última instancia el trato con el mundo circundante, la preocupación práctica propia de él.

${ }^{199}$ Axel Honneth se inscribe en la tercera generación de la teoría crítica, y fue director, desde 2001 hasta 2018 , del Institut für Sozialforschung de la Universidad de Frankfurt. Sobre las diferentes etapas que atraviesa el Instituto, ver Wiggershaus (2010). 
relación del hombre con el medio y con los otros, y al hacerlo abre el juego para incluir el aporte de Heidegger en un problema tradicionalmente abordado desde perspectivas marxistas. Será justamente Heidegger quien realice, como mencionamos, un profundo cuestionamiento de la metafísica occidental basado en el señalamiento del olvido de las formas originarias de la relación del hombre con el mundo, o, lo que es lo mismo, de la experiencia. En sus palabras: "El estar-en-el-mundo -aunque prefenomenológicamente experimentado y conocido- se hace invisible [unsichtbar] como consecuencia de una interpretación ontológicamente inadecuada [ontologisch unangemessenen Auslegung]" (Heidegger, 2006, p. 85; SuZ 59. Enfatizado en el original). En efecto, y como expone Honneth,

el autor de Ser y tiempo está convencido de que el primado de la idea de una aprehensión neutral de la realidad es responsable de las cegueras ontológicas que han impedido que se diera una respuesta adecuada a la pregunta sobre las estructuras de la existencia del hombre. (2007, p. 40)

Como mencionamos, Heidegger propone una respuesta a esta pregunta por las estructuras de la existencia humana que se erige sobre el concepto de cuidado. Este concepto, como el de estar-en-el-mundo, señala que la realidad "nos es dada como un campo de significaciones prácticas" (Honneth, 2007, p. 41), y que las cosas no se dan aisladas y dispuestas para la observación, sino como parte de un plexo de significados previo, en el que tanto el hombre cuanto las cosas de que se ocupa están inmersos.

En este contexto, el conocimiento, lejos de ser el modo originario de nuestra relación con el medio, se funda en un, en palabras de Heidegger,

ya-estar-en-medio-del-mundo [Schon-sein-bei-der-Welt $]$, que constituye esencialmente el ser del Dasein. Este ya-estar-en-medio-de [Schon-sein-bei] no es un mero quedarse boquiabierto mirando un ente que no hiciera más que estar presente [ein starres Begaffen eines puren Vorhandenen]. El estar-en-el-mundo 
como ocupación está absorto [benommen] en el mundo del que se ocupa. Para que el conocimiento como determinación contemplativa de lo que está-ahí [Erkennen als betrachtendes Bestimmen des Vorhandenen] llegue a ser posible, se requiere una previa deficiencia del quehacer que se ocupa del mundo [einer Defizienz des besorgenden Zu-tun-habens mit der Welt]. (2006, p. 87; SuZ 61. Enfatizado en el original)

Es así que los entes, esos útiles que están a la mano mucho antes que a la vista del hombre (que es antes unas manos que hacen que unos ojos que ven), sólo serán objetos de un sujeto mediante una operación ${ }^{200}$, ya que cuando nos referimos al trato originario del hombre con el mundo nos situamos antes de la escisión entre el sujeto y el objeto ${ }^{201}$.

Ahora bien, a diferencia del caso de Benjamin, que parte, para su redefinición de la experiencia, del diagnóstico de un empobrecimiento de la misma y de la denuncia de procesos estetizantes, en el caso de Heidegger puede parecer que en principio "las condiciones reificadas sólo constituyen un marco de interpretación falso, un velo ontológico detrás del cual se esconde la facticidad de la forma efectiva de la existencia humana" (Honneth, 2007, p. 43). No obstante, el análisis de la existencia humana que se despliega en Ser y tiempo muestra, en la tematización del uno, de la existencia inauténtica y del quiebre de la familiaridad que experimenta el Dasein en su caída (Picotti, 2010, p. 15), un diagnóstico de las condiciones de existencia que las revela problemáticas. Al respecto sostiene Safranski que "Heidegger piensa desde la experiencia del malestar" (2003, p. 189) y agrega, refiriéndose a los dichos de Freud que citamos al inicio de esta sección: "y se niega a presentarse como profeta y 'ofrecer consuelo"” (2003, p. 189). En efecto, Honneth da cuenta también una preocupación por el estado de la relación concreta del Dasein con el mundo. En sus palabras:

\footnotetext{
${ }^{200}$ De allí que, como repone Parente, "Heidegger afirme la transparencia del útil: cuando estamos usando un útil apropiadamente, éste tiende a desaparecer" (2010a, p. 143). Al respecto véase también Parente (2010b).

${ }^{201}$ Como pone de relieve Didier Franck, "estas precisiones eran doblemente necesarias para mostrar cómo la ontología tradicional, tomando su hilo conductor en el conocimiento, se condena a perder el fenómeno del ser-enel-mundo, a la vez que ponen de relieve el seso y la función de la destrucción fenomenológica” (2011, p. 53).
} 
"reificación" quiere decir (...) una costumbre de pensamiento, una perspectiva que se fosilizó y se convirtió en hábito, a partir de cuya adopción el sujeto pierde la capacidad de implicarse con interés, del mismo modo que su entorno pierde el carácter de accesibilidad cualitativa. (2007, p. 51)

Como es evidente, a lo largo de su estudio Honneth redefine la reificación, dejando de entenderla como la forma de praxis fallida que era en Lukács, y propone comprenderla como un problema entre lo que él llama -recuperando conceptos hegelianos- el reconocimiento y el conocimiento, como dos instancias en la relación con el mundo: "reconocimiento" nombra la relación originaria de cuidado, mientras que "conocimiento" se refiere a la relación entre el hombre y el mundo mediada por la escisión entre el sujeto y el objeto. La reificación acaba siendo, luego de lo que podríamos llamar una heideggerización de Lukács, un olvido de la forma originaria de la relación con el mundo. Podemos decir ahora, con Honneth, que es posible encontrar en el Heidegger de Ser y tiempo el problema de una relación reificada con el mundo, a saber, la relación entre el sujeto que conoce y un objeto dado que se deja conocer, y más aún, esa relación de conocimiento sólo en la medida en que ha cumplido el rol de ocultar la relación de trato (o de reconocimiento) que está en su propia base.

Con este concepto ampliado de reificación, es más fácil entender que el cuidado sea, para Honneth, una respuesta a este problema. Para Heidegger, “'teoría' y 'praxis' son posibilidades de ser de un ente cuyo ser debe ser definido como cuidado ['Theorie' und 'Praxis' sind Seinsmöglichkeiten eines Seienden, dessen Sein als Sorge bestimmt werden muß]' (Heidegger, 2006, p. 215; SuZ 193).

Consideramos que el problema de la reificación resaltado por Honneth en su estudio, enriquecido con los aportes teóricos de Heidegger, guarda relación con el problema central con el que trabaja Benjamin en la década del 30, a saber, la crisis de la experiencia. En este punto, podríamos citar las palabras de Adorno, quien en una carta a Benjamin se pregunta: 
¿Acaso (...) la auténtica tarea no consiste aquí en relacionar la total oposición entre la experiencia sensorial [Erlebnis] y la experiencia propiamente dicha [Erfahrung] con una teoría dialéctica del olvido? ¿O, lo que es lo mismo, relacionarla con una teoría de la reificación? Pues toda reificación es un olvido. (citado por Jay, 2009, p. $388)^{202}$

En efecto, en los lamentos por el estado de la experiencia late la idea de una forma de relación con el mundo que dejó de ser posible, aun cuando las diferencias con Heidegger resulten también atendibles. La crítica de Benjamin y Heidegger a la concepción tradicional de la relación del hombre con el mundo es central, y ambos tienen en común la propuesta de redefinir, a la vez que la relación, a los términos que la sustentan. En Heidegger, la existencia humana es un estar en el mundo, por lo que su relación con él, lejos de obligarlo a salir de sí, le es inherente. En Benjamin, el "sujeto" de la experiencia dista mucho, como vimos en el capítulo 5, de identificarse con aquel sujeto de la tradición.

Ahora bien, en Heidegger, el cuidado es una estructura que se descubre en la existencia humana, y que aun cuando se encuentre oculta por la tradición, late aún en el trato con el mundo como su modo originario. En Benjamin, en cambio, la experiencia no tiene este carácter originario: la constatación de su crisis cuestiona el hecho de que aún sea posible e invita, en este sentido, a pensar posibles modos para su salvación o para su supervivencia, poniendo un esfuerzo mayor en el análisis de sus transformaciones.

A primera vista, la apelación heideggeriana a lo originario indicaría un apego mayor a indicar estructuras atemporales. Aun así, el diagnóstico de la época y el trabajo comparativo que lleva a cabo Heidegger habitualmente respecto a diferentes períodos y configuraciones

\footnotetext{
${ }^{202}$ Se trata de la carta fechada el 29 de febrero de 1940 a la que nos referimos en el capítulo 5 y que forma parte de los últimos intercambios que pudieron tener los amigos antes de la muerte de Benjamin. El contexto de las preguntas que lanza Adorno y que aquí cita Jay es su crítica a la argumentación de Benjamin en torno a la relación entre la experiencia y la memoria involuntaria (Adorno y Benjamin, 1994, p. 305 y ss). Sobre este intercambio, ver Lijster (2017).
} 
históricas dan cuenta del intento de dejar atrás definiciones ahistóricas de sujeto. En efecto, las reflexiones sobre la historicidad y el tiempo son centrales en su producción, como tendremos oportunidad de repasar en el apartado 6.5 de este capítulo.

Sin embargo, antes de abocarnos a ello seguiremos indagando en el diagnóstico heideggeriano de la época moderna y en los modos en que sus ideas se cruzan con las de Benjamin en torno a sus reflexiones sobre el arte y la experiencia sensible. Allí, lejos de centrarse exclusivamente en el arte, Heidegger despliega también su pensamiento respecto de la relación del existente humano con aquello que lo rodea.

\subsection{La obra de arte y la técnica: su despliegue espacial}

A menudo aporta más a la comprensión de la subjetividad humana un estudio sobre Proust (...) que un experimento con ratas enloquecidas que viven en condiciones de cautividad extrema.

César Rendueles, 2011

Como mencionamos en la introducción a este capítulo, una de las coincidencias más señaladas entre Benjamin y Heidegger es el año de publicación de sus trabajos más importantes sobre la obra de arte. Comay (2010) afirma, por ejemplo, que responden a una misma encrucijada, a saber, la relación del arte con la política y con la tecnología ${ }^{203}$, que se hace presente con mucha fuerza hacia la mitad de la década del 30 a partir del despliegue visual y espacial que pone en marcha el régimen fascista.

Vardoulakis (2015) hace hincapié en la relación entre arte y política por otra vía, y plantea que ambos textos, lejos de limitarse al arte, se alzan como manifiestos contra la

\footnotetext{
${ }^{203}$ Caygill (1994, p. 22), sostiene que el tema de ambos escritos es el impacto de la tecnología en la tradición, el arte y la política. Para el autor, en estos textos cristalizan ideas que los autores desarrollaron hacia finales de los años 20, en el caso de Heidegger en Ser y tiempo, y en el caso de Benjamin en Calle de mano única.
} 
inmediatez (p. 237), estructurados en torno a la recuperación, en el caso de Heidegger, de la tradición griega y, en el de Benjamin, de algunos temas románticos. En ambos casos, señala el autor, la respuesta a la inmediatez negará la autonomía del arte tanto como la autonomía de la política, e implicará una tarea: en Heidegger, la construcción o la fundación de algo nuevo que mira al futuro; en Benjamin, la politización del arte y de la vida que reniega de las utopías y hace pie en el pasado oprimido. Ferris (2015), por su parte, advierte que la insistencia en las diferencias entre los escritos puede obturar la visión de aquello que tienen en común, a saber, un análisis de la obra de arte que la descubre como imposible de comprender valiéndose solo de las categorías tradicionales de la estética (p. 261).

En nuestro caso, nos interesa detenernos en primer lugar en un aspecto de los textos que suele obviarse y que creemos muy relevante, a saber, su carácter de ensayos. Si pensamos, como tendremos oportunidad de ampliar en el próximo capítulo, a la filosofía como un trabajo con el lenguaje que se topa, a cada viraje y citando a Benjamin, con la cuestión de la exposición (2006, p. 223; GS I 207), el recurso al ensayo para explorar y expresar el propio pensamiento no puede descartarse como una mera casualidad. En el caso de Benjamin, se trata de un género recurrente en el que el autor es, como supo ver Adorno, "el maestro insuperado" (2001, p. 22). En torno a Heidegger, da cuenta -fundamentalmente si se piensa en Ser y tiempo-de un cambio de pretensión que es interesante señalar, y que se acentúa con el paso de los años. En "La pregunta por la técnica", por ejemplo, Heidegger dirá que "todos los caminos del pensar conducen, más o menos perceptiblemente y de una manera inhabitual, a través del lenguaje" (1997, p. 113). Leyte (2016), tras dar cuenta de la historia de la edición de "El origen de la obra de arte", apunta en un sentido similar al preguntarse

si su inicial carácter inédito respondía a la convicción de que sólo los sucesivos ensayos verbales, bajo la forma de conferencias, o textos escritos, podían ir revelando qué se pretendía expresar y, antes que nada, si realmente se pretendía 
formular una tesis sobre el arte, sobre la propia filosofía en general o, por el contrario, precisamente se trataba de renunciar a cualquier tesis. (2016, p. 10)

La inclusión del texto en Holzwege, siguiendo a Leyte, "se hace cargo, aunque sea metafóricamente, del tono de un discurso inseguro y de naturaleza improbable que sólo podía adoptar la forma de un ensayo, pero nunca de un libro cerrado" (2016, p. 10). En efecto, y si bien el Heidegger de Ser y tiempo se acerca en los temas por momentos a Benjamin, sus intentos posteriores se le acercan en los formatos, lo que no resulta para nada menos significativo. El “carácter fragmentario y hasta casual” (Leyte, 2016, p. 10) que adquieren sus reflexiones en la década del 30, más cerca del rodeo benjaminiano que de la pretensión sitemática de Sein und Zeit, da cuenta de una reflexión sobre el lenguaje y sobre el modo del hacer filosófico de quien ha comprendido que "la filosofía no puede partir ya de un principio o presupuesto incondicional -la razón, la realidad, la acción, la subjetividad-, sino que tiene que poner expresamente en evidencia la imposibilidad de tales principios" (Leyte, 2016, p. 11). Este poner en evidencia, agregamos, no es un poner en evidencia temático: como motivo, la imposibilidad de encontrar un punto fijo en torno al cual construir el edificio del saber filosófico había quedado clara ya en $1927^{204}$; sin embargo, la pretensión performativa del libro parecía querer de algún modo perseguir ese fin $-\mathrm{y}$ su inconclusión puede leerse, en ese sentido, como la confesión de un fracaso o de un abandono de la empresa-. El ensayo sobre la obra de arte, por su parte, asume ya desde la forma "la imposibilidad de escribir ya una "obra filosófica"” (Leyte, 2016, p. 12).

\footnotetext{
${ }^{204}$ La búsqueda de un lenguaje para la filosofía acompaña a Heidegger durante toda su producción. En torno a ella escribe Escudero en El lenguaje de Heidegger (2015): "El lenguaje de Heidegger ha sido objeto de muchas críticas por su carácter críptico y en ocasiones esotérico, por su violencia semántica y su excesivo afán de autenticidad, por sus arcaísmos y sus heterodoxas reconstrucciones etimológicas, por sus innovaciones terminológicas y su falta de coherencia interna. Pero a pesar de todas las críticas recibidas, muchas de sus formulaciones lingüísticas se dejan sentir con fuerza en la filosofía y en otros ámbitos del conocimiento. En cualquier caso, la peculiaridad del lenguaje de Heidegger está íntimamente entretejida con la de su pensamiento. Lenguaje y pensamiento resultan indisociables en el caso de Heidegger, de quien se puede afirmar que crea un universo lingüístico propio en torno a las múltiples formas de manifestación del ser” (p. 9).
} 
Volviendo a los problemas que aborda el texto, y antes de pasar a su análisis, nos interesa dejar clara nuestra pretensión de evitar caer en un antagonismo simple como el que menciona Comay, esto es, "enfrentar a Heidegger con Benjamin como portavoces, respectivamente, de la autonomía estética y de la cultura popular, o del desinterés y del compromiso" (2010, p. 143). La autora hace un esfuerzo por no reducir el encuentro a una mera comparación y por no caer en oposiciones forzadas construidas en base a los estereotipos que representan los autores, y lo hace planteando preguntas que Heidegger podría formularle a Benjamin, como por ejemplo: ¿no se entrega éste al valor de exhibición al abandonar el de culto?

Asimismo, Ruiz Zamora, en su ensayo "Martin Heidegger/ Walter Benjamin: un antagonismo a partir de la obra de arte" (2006), y aun cuando argumenta a favor de leer las propuestas de los autores como antagónicas, da cuenta de un punto de partida común. En sus palabras:

no es posible obviar, sin embargo, más allá de la evidente divergencia de los enfoques, una identidad de intereses especulativos que nace a nuestro juicio de una circunstancia determinante en la producción estética de la década de los treinta: la incontestabilidad con la que las posibilidades técnicas se van instalando en el mundo, hasta entonces incontaminado, de la creación artística. (p. 256)

Centrémonos en el texto, donde es menester señalar algunos gestos ya desde el comienzo. Heidegger abordará el arte desde la materialidad de su existencia efectiva: obra, artista y trabajo [Handwerk] ocupan el lugar que podría haber alojado otras abstracciones. A su vez, la típica pregunta por la definición da lugar a una pregunta más concreta: “¿dónde y cómo hay arte?" [Wo und wie gibt es die Kunst?].

Heidegger vuelve a la "experiencia fundamental [Grunderfahrung] griega del ser de lo ente en el sentido de la presencia" (Heidegger, 2016, p. 31) y a la traslación latina de esta 
experiencia a un modo diferente de pensar que inaugura la "interpretación occidental del ser de lo ente" (2016, p. 31) en términos de una cosa con propiedades, una sustancia con accidentes y un sujeto con predicados, y lo hace para proponer otro acercamiento. Si no atropellamos a las cosas con nuestro control, es posible percibir en el encuentro inmediato con ellas su propia agencia, tal y como vimos en el caso de Benjamin. En este sentido -cabe aclarar- el texto no se limita al arte como tema, sino que trabaja, como el célebre ensayo de Benjamin, con la experiencia en sentido amplio, esto es, con la relación del existente humano con su entorno. Al hacerlo, continúa desarticulando el binomio sujeto/objeto y sigue en la búsqueda de dar cuenta de la articulación real que tiene lugar entre nosotros y las cosas. El siguiente pasaje es, en este sentido, esclarecedor:

¿Es posible evitar semejante atropello? ¿De qué manera? Probablemente solo es posible si le concedemos campo libre a la cosa con el fin de que pueda mostrar de manera inmediata su carácter de cosa. Previamente habrá que dejar de lado toda concepción y enunciado que pueda interponerse entre la cosa y nosotros. Solo entonces podremos abandonarnos en manos de la presencia imperturbada de la cosa. Pero no tenemos por qué exigir ni preparar este encuentro inmediato con las cosas, ya que viene ocurriendo desde hace mucho tiempo. Se puede decir que en todo lo que aportan los sentidos de la vista, el oído y el tacto, así como en las sensaciones provocadas por el color, el sonido, la aspereza y la dureza, las cosas se nos meten literalmente en el cuerpo. (Heidegger, 2016, p. 35. El enfatizado es nuestro)

La interpretación heideggeriana de los entes se aleja, así, de la mera imagen en la que la filosofía de la representación ha convertido al mundo, y al hacerlo se aleja también del mito de la diferencia imperturbable, de la distancia insalvable, entre el hombre y aquello que meramente lo rodea. A continuación, agrega: 
Cuando se nos aparecen las cosas nunca percibimos en primer lugar y propiamente dicho un cúmulo de sensaciones, (...) por ejemplo, una suma de sonidos y ruidos, sino que lo que oímos es cómo silba el vendaval en el tubo de la chimenea, el vuelo del avión trimotor o el Mercedes que pasa y que distinguimos inmediatamente del Adler. Y es que las cosas mismas están mucho más próximas de nosotros que cualquier sensación [viel näher als alle Empfindungen sind uns die Dinge selbst] (...) Para poder oír un ruido puro tenemos que hacer oídos sordos a las cosas, apartar de ellas nuestro oído, es decir, escuchar de manera abstracta. (2016, p. 35. El enfatizado es nuestro)

Nos interesa detenernos especialmente en dos elementos en esta descripción que se cruzan con las reflexiones de Benjamin. Por un lado, la agencia de las cosas, a la que ya nos referimos: hacer oídos sordos a las cosas sólo es posible si admitimos que, en alguna medida, ellas nos hablan. Por otro lado, la cercanía y en general la tematización de la relación espacial con el mundo. Recordemos que Benjamin registra, en Einbahnstraße, que "las cosas han arremetido con demasiada fuerza contra la sociedad humana" (2014, p. 103).

La distancia que, como pudimos apreciar en el caso de Simmel, es establecida entre las cosas y nosotros por el arte y que, en Benjamin, motoriza figuras paradójicas en la caracterización del arte aurático y se ve reducida por la reproductibilidad técnica, que acerca las cosas, aparece también en este texto de Heidegger en alguna medida como una ficción: tal y como el conocimiento implica, en Ser y tiempo y como mencionamos, un tomar distancia de la relación de cuidado con el mundo, la apreciación a través de las sensaciones implica una abstracción que aleja a las cosas tal y como se presentan como parte de nuestro entorno, como aquello que se nos mete literalmente en el cuerpo (Heidegger, 2016, p. 35$)^{205}$.

Sin embargo, esta concepción de la cosa como aquello que se da siempre en la cercanía no será tampoco la que dé con el ser de la cosa. A su manera, Heidegger también oscila entre

\footnotetext{
${ }^{205}$ Peter Sloterdijk (2011) ha sostenido que "bajo el sensacional título programático de El ser y el tiempo se oculta también un tratado, germinalmente revolucionario, sobre el ser y el espacio” (p. 263).
} 
la cercanía de lo habitual y lo disponible y la lejanía del objeto que afecta a nuestros sentidos y cuyas características somos capaces de abstraer. Trabajando mediante un rodeo, explorando formas de enfocar el objeto, Heidegger concluye que "mientras que la primera interpretación de la cosa la mantiene a una excesiva distancia de nosotros, la segunda nos la aproxima demasiado. En ambas interpretaciones la cosa desaparece" (Heidegger, 2016, p. 37).

La posición que dejaría atrás a estas dos aparece auxiliada por el esquema que, según Heidegger, caracteriza a la estética y la teoría del arte, a saber, la diferenciación entre materia y forma. Como es esperable, esta forma de comprender el ser de la cosa, lejos de operar como justo medio, será duramente criticada: se trata de la matriz del pensar representativo, que pretende poder dar cuenta de todos los fenómenos y los fuerza a entrar en categorías conceptuales que no siempre les son propias. Heidegger, por su parte, tras denunciar el sesgo bíblico que caracteriza a este esquema y dar cuenta de que la metafísica moderna arrastra este sesgo porque reposa en parte sobre el entramado de la metafísica medieval, preferirá distinguir a la cosa $[$ Ding $]$ del utensilio [Zeug] y de la obra [Werk] y darle a cada una la posibilidad de mostrarse o, en sus palabras, "dejar ser al ente como es" [das Seiende sein zu lassen, wie es ist] (2016, p. 45).

La cercanía o, mejor, la disponibilidad, será central en el análisis que sigue. Lo más célebre del texto es quizá esta diferenciación entre el útil y la obra basada en el recurso a los zapatos pintados por Van Gogh en 1886. La fiabilidad [Verläßlichkeit] de su ser-utensilio, su conexión con el ser refugio [Geborgenheit] del mundo, es lo que da a las botas de labranza su verdad como utensilio, pero esto es comprensible no a través del uso de las botas ni de su observación en el contexto de la cotidianidad: es la obra la que abre esta verdad. En palabras del autor: "Ha sido la obra de arte la que nos ha hecho saber lo que es de verdad un zapato" (2016, p. 55). 
La tesis de Heidegger es entonces que el arte obra un desocultamiento del ser del ente, que sale a la luz en la obra y puede hacerlo sólo en ella. Lejos de la representación, lo que sucede es un acontecimiento de la verdad, con lo que el autor logra desarmar aquella vieja diferencia con la que ya había tratado: la verdad y la belleza no se corresponden, respectivamente, con lo racional y lo irracional, con la forma y la materia, con el intelecto y la sensibilidad. Cuando asistimos al acontecimiento de la verdad en la obra, se hace manifiesto también que algo no cuadra en la idea de que "la verdad pertenece al reino de la lógica, mientras que la belleza está reservada a la estética” (Heidegger, 2016, p. 57). Más adelante en el texto, Heidegger llegará a decir que "la belleza es uno de los modos de presentarse la verdad como desocultamiento" (2016, p. 97. En cursiva en el original $)^{206}$.

Ahora bien, la verdad, reintroducida en el ámbito del arte -y de alguna manera expropiada tras su monopolio en manos del discurso científico-, no se identificará con la idea de representación o copia fiel y operará, en efecto, en su contra: la obra no es una copia exitosa de un par de botas, sino que es "ese ponerse a la obra de la verdad" (Heidegger, 2016, p. 63). Y dicho esto, cabe entonces preguntarse: “¿Qué será la verdad misma, para que a veces acontezca como arte?” (Heidegger, 2016, p. 63).

Como queda en evidencia, no son simplemente los postulados de la teoría del arte los que quedan puestos en entredicho, sino el hecho mismo de que el arte sea pensado como una esfera separada. Tal y como Benjamin en su ensayo, Heidegger desborda en este texto las reflexiones sobre el arte para permitirse, por un lado, una indagación acerca de la verdad y, por el otro, una reflexión acerca del sistema de producción y difusión de las artes -la empresa artística [Kunstbetrieb]-, que lidia con el aspecto de útil de las obras, en pasajes que se acercan a lo que hoy denominaríamos como estudios sociales del $\operatorname{arte}^{207}$. Es también en ese rango

\footnotetext{
${ }^{206}$ Long (2001) ha sostenido que aquello que tiene lugar en la obra no es otra cosa que el aura (p. 101).

${ }^{207}$ Hemos indagado la relación de Benjamin con este campo de estudio, del que es un antecedente relevante, en Rueda y Staroselsky (2020).
} 
amplio que va del análisis micro al macro, en el terreno plagado de tensiones en el que se cruzan la metafísica y la historia cultural, donde Heidegger y Benjamin se encuentran más de una vez.

En el contexto del análisis de la segunda obra de la que se ocupa, el templo de Atenea, Heidegger introduce la noción de tierra [Erde]. Si bien no nos centraremos en esta idea, ni en su relación con la de mundo [Welt], es importante señalar que la tierra refiere tanto al hacer patente en la obra la materialidad de lo que está hecha, como también a lo opaco, es decir, a aquel elemento de la obra que, replegándose sobre sí mismo, se sustrae y se resiste a la interpretación totalizadora dando lugar, en su lugar, a la posibilidad de nuevas interpretaciones. A su vez, en torno a las ideas de tierra y mundo reaparecen la espacialidad y el eje de la cercanía y la distancia. El proceso de sucesivo alejamiento del entorno, su contemplación distanciada que, como hemos argumentado, puede conceptualizarse como un proceso de estetización, no es ajeno a la experiencia epocal del propio Heidegger, quien rechazó tanto como Benjamin la idea de un arte meramente representativo (Ferris, 2015, p. 260). En el texto que de momento nos ocupa, y redefiniendo algunos motivos ya presentes en Ser y tiempo, nuestro autor intenta recuperar cierta cercanía con el entorno a partir de la idea de tierra, en torno a la que escribe:

De lo que dice esta palabra hay que eliminar tanto la representación de una masa material sedimentada en capas como la puramente astronómica, que la ve como un planeta. La tierra es aquello en donde el surgir vuelve a dar acogida a todo lo que surge en cuanto tal. En eso que surge, la tierra se presenta como aquello que acoge. (2016, p. 71)

Cabe recordar en este punto las palabras de Baudelaire que cita Benjamin y a las que nos referimos en el capítulo 5: "Desde lo alto contemplo la redondez del globo, y ya no busco en él de una choza el abrigo" (Benjamin, 2008c, p. 250). Ante la lejanía que supone la tendencia a pensar al mundo como objeto, la tierra opera una resistencia, en tanto elemento de la obra que da batalla contra su reducción a mero objeto de consumo, análisis o goce estético. 
El ejemplo del templo es productivo en tanto con él es posible descartar de una vez la opción de la representación: en el caso de los zapatos la idea de que la obra logra abrir una verdad porque refleja fielmente el objeto resulta más tentadora, o al menos atendible. Sin embargo, erigir un templo no busca nada ni remotamente similar a representar a un dios, sino que intenta, más explícitamente, permitir que se haga presente, hacerle lugar: “¿Qué instala la obra en tanto que obra? Alzándose en sí misma, la obra abre un mundo" (Heidegger, 2016, p. 75).

La aproximación que hace Heidegger a la idea de mundo [Welt] vuelve a remitir a las ideas de hogar y de habitar, alejándose del binomio sujeto-objeto. En sus palabras:

Un mundo no es una mera agrupación de cosas presentes contables o incontables, conocidas o desconocidas (...). Un mundo no es un objeto que se encuentre frente a nosotros y pueda ser contemplado. Un mundo es lo que nunca aparece como objeto. (2016, p. 75. El enfatizado es nuestro).

Si bien los conceptos de tierra y mundo pueden resultar ajenos al tipo de procedimientos que despliega Benjamin en su análisis de la reproductibilidad técnica, en su exposición aparecen puntos de contacto relevantes. En la experiencia con la obra se revela una verdad que no puede ser reducida a la matriz explicativa de la ciencia. La narración, en Benjamin, se comporta de una manera análoga, y su misma pretensión en la Obra de los pasajes apunta a un objetivo similar: "Nada que decir, sólo mostrar" (Benjamin, 2013, p. 739). En Heidegger, tanto la representación y la relación de mera observación distanciada como la reducción de toda relación a una relación anclada en la actitud cognoscitiva son puestas en cuestión. La tierra, como el color,

sólo se muestra cuando permanece sin descubrir y sin explicar. (...) Convierte en destrucción toda curiosa penetración calculadora. Por mucho que dicha intromisión pueda adoptar la apariencia del dominio y el progreso, bajo la forma de la 
objetivación técnico-científica de la naturaleza, con todo, tal dominio no es más que una impotencia del querer. (2016, p. 79)

La obra, entonces, pone en pie un mundo y trae aquí la tierra, sin escudriñarla. Ahora bien, en este punto de su argumentación Heidegger suma una variable que, en términos de pensar sus relaciones con las ideas de Benjamin, es muy relevante: "la actividad del artista" (2016, p. 101) que Heidegger entiende como creación [Schaffen] y a la que añade luego la actividad del "cuidador" [Bewahrende] en tanto "el intento de determinar el ser-obra de la obra única y exclusivamente a partir de ella misma ha demostrado ser inviable” (2016, p. 101). Acerca de la idea de creación, cabe aclarar que la intención de Heidegger no es plegarse a la tradición del genio creador: es consciente de que "el subjetivismo moderno malinterpreta de inmediato lo creador en el sentido de un genial resultado logrado por el sujeto soberano" (Heidegger, 2016, p. 133). Así lo afirma también Melamed, para quien el texto de esta conferencia

contribuye de manera decisiva a desmontar el mito del origen. Aunque mantiene filiación con la propuesta romántica del origen al buscar una esencia del arte y al establecer en la obra una nueva relación con el ser y con el acontecer de la verdad, no obstante, Heidegger pone el acento en que todo arte tiene la posibilidad de abrir un mundo, un campo de significaciones o de circulación de sentidos y restringe, así, el papel del artista creador, central para el Romanticismo. (2016b, p. 46)

En efecto, el énfasis en el crear y el cuidar la obra la devuelven al mundo de la acción humana, aunque sin desmerecer su carácter de otredad y la potencialidad de su presencia. Así como en Benjamin la experiencia, en todas sus facetas, implica un encuentro transformador con otra agencia, humana o no, para Heidegger el arte estará del mismo modo alejado del mero consumo cultural. Dos fragmentos del texto ilustran este punto. Por un lado, Heidegger da cuenta de la capacidad que tiene la obra de transformar el entorno, siendo en algún sentido un 
dispositivo que abre para nosotros un mundo más amplio que el que ya habitábamos. En el lenguaje de Heidegger:

Cuanto más solitaria se mantiene la obra dentro de sí, fijada en la figura, cuanto más puramente parece cortar todos los vínculos con los hombres, tanto más fácilmente destaca ese impacto de que dicha obra sea, tanto más esencialmente emerge lo inquietante e inseguro mediante el empuje que supone dicho impacto, $y$ tanto más esencialmente se transforma con él lo que hasta ahora parecía seguro. Pero todas estas distintas formas de impacto no entrañan ninguna violencia, porque cuanto más puramente se queda replegada y retirada la obra dentro de la apertura de lo ente abierta por ella misma, tanto más fácilmente nos empuja y adentra a nosotros en el interior de esa apertura y, por consiguiente, nos empuja y desplaza al mismo tiempo fuera de lo habitual"'. (Heidegger, 2016, p. 116-117. El enfatizado es nuestro)

El fragmento da cuenta también de una coincidencia con Benjamin, a saber, el análisis de la cerrazón o la apertura de la obra que se despliega en lo espacial, en una cierta topografía de la experiencia estética. La obra no sólo nos empuja y nos impacta, sino que también nos traslada y desplaza, nos acerca y nos aleja.

En segundo lugar, el encuentro con la obra no se limita a la "mera vivencia [Erlebnis]" (Heidegger, 2016, p. 119) y el "mero deleite artístico $[\text { Kunstgenuß }]^{208 "}$ que se movilizan en la empresa artística encargada del proceso de transmisión, sino que hay una potencialidad en la obra que desborda ese circuito. En el caso de Heidegger, este desborde está ligado a un saber de la verdad, en tanto "saber no consiste solo en un mero conocer o representarse algo" sino que es pensado a partir de la "experiencia fundamental del pensar [Grunderfahrung des Denkens]".

\footnotetext{
${ }^{208}$ En "Literaturgeschichte und Literaturwissenschaft" Benjamin se separa también de este concepto, al que coloca como una de las siete cabezas de lo que llama la Hidra de la escuela estética [Hydra der Schulästhetik]. Las otras seis cabezas son: "creatividad, empatía, atemporalidad [Zeitentbundenheit], recreación [Nachschöpfung], identificación [Miterleben], ilusión” (GS III, p. 286. Traducción propia).
} 
En torno a esta cuestión resultan relevantes algunas ideas que Heidegger expone en el epílogo. Allí aclara que sus reflexiones giran en torno al enigma [Rätsel] del arte, que no intentan resolver sino ver $(2016 \text {, p. 141) })^{209}$, y se separa de la estética en tanto esta "toma la obra de arte como un objeto, concretamente un objeto de la aisthesis, de la percepción sensible en sentido amplio" (2016, p. 141), a la que llama también vivencia [Erlebnis] y de la que afirma: “quizá sea la vivencia el elemento en el que muere el arte” (2016, p. 141). La vivencia aparece, como en Benjamin, asociada a una relación con la obra que olvida o esquiva su potencial transformador, a saber, el de romper con lo habitual y lo banalizado, el de ponernos ante lo extraño, inquietante e inseguro, ante aquello que no podemos reducir a mera fuente de conocimiento o disfrute.

El epílogo también ofrece una distinción relevante entre el "alzarse de la estatua (es decir, la presencia de un resplandor que nos contempla)" (2016, p. 147) y el "alzarse de eso que se alza enfrente al modo del objeto" (2016, p. 147). El juego de miradas que se da en el primer caso recuerda muy directamente al aura a la que se refiere Benjamin en su propio ensayo sobre la obra de arte, mientras que el alzarse como mero objeto parece tener un paralelismo con el valor de exposición tal y como lo entiende el filósofo de Berlín ${ }^{210}$.

Volviendo entonces a la relación entre los ensayos sobre la obra de arte de Benjamin y de Heidegger, una de las diferencias más evidentes es, como se ha señalado, la valoración de la técnica, así como también del arte de masas. La técnica, que en Heidegger remite a la comprensión moderna del ser, limitada a la racionalidad cientificista dominante, en Benjamin se vincula con la fuerza productiva de la tradición marxista: si bien el autor no es ingenuo en torno a la valoración de los avances técnicos - como queda claro en "Experiencia y pobreza"

\footnotetext{
${ }^{209}$ En el apéndice Heidegger mismo lo deja claro: "Qué sea el arte es una de esas preguntas a las que no se da respuesta alguna en este ensayo. Lo que parece una respuesta es una mera serie de orientaciones para la pregunta" (2016, p. 151).

${ }^{210}$ Agambem sostiene respecto del concepto de valor de exposición [Ausstellungswert] benjaminiano que: "Nada mejor que este concepto podría caracterizar la nueva condición de los objetos y hasta del cuerpo humano en la edad del capitalismo realizado" (2005, p. 117).
} 
tanto como en su crítica a la ideología del progreso-, late en sus reflexiones sobre el arte la posibilidad de que la era de la reproductibilidad técnica aloje también un potencial emancipatorio. A su vez, y en torno al acercamiento de las masas al arte que este proceso habilita, Benjamin insiste en su potencia liberadora, y en alguna medida puede pensarse que el aura que Benjamin nos invita a liquidar aparecería en Heidegger como un valor a resguardar, como ha planteado Christopher Long (2001, p. 90). No obstante, como recuerda Comay, con respecto al fin del arte aurático y a la recepción del arte en la dispersión por parte de la masa, la "ambivalencia de Benjamin debe al menos ser advertida" (2010, p. 146). Asimismo, más allá de estas diferencias más evidentes, en ambos el camino del arte se alza como una vía posible de restitución de la experiencia en la medida en que la obra de arte tiene un determinado potencial: en Benjamin, el de hacernos ver aquello que no miramos, como en el teatro brechtiano o en el cine; en Heidegger, el de alzar un mundo y dar cuenta de una verdad para la cual, sin arte, sería difícil hacer lugar ${ }^{211}$.

Como coincidencia relevante cabe mencionar también la que se teje en torno a la destrucción, central en Benjamin: en el caso de Heidegger, para volver a descubrir la cosa por medio de la obra de arte es preciso operar una destrucción de la tradición que confinó al arte al mero goce estético, la contemplación y el disfrute subjetivo (Leyte, 2016, p. 13). Si entendemos, con Leyte, que una de las preguntas que se hace el texto es justamente “¿cómo aproximarse al fenómeno 'arte' sin los presupuestos ni sobreentendidos que simplemente hicieron del mismo, primero una esfera decisiva de la nueva cultura burguesa y, después, en la estela disolutiva de aquella cultura, solo un entretenimiento de masas?" ${ }^{212}$, es difícil dejar de

\footnotetext{
${ }^{211}$ Ferris (2015) pone el foco en este modo en que tanto Benjamin como Heidegger rechazaron la visión del arte como una actividad meramente representativa y se preguntaron por su significado y su valor una vez puesta en cuestión la pregunta por su utilidad. En este contexto, el autor encuentra que Benjamin pone el eje de la discusión en la función del arte, mientras que Heidegger va más allá y relaciona el significado del arte con el aparecer de una verdad.

${ }^{212}$ En la interpretación de Leyte, "la pregunta del texto de Heidegger acerca de 'si el arte sigue siendo todavía un modo esencial y necesario en el que acontece la verdad... o si ya no lo es' sigue siendo idéntica a la pregunta por si sigue siendo posible la filosofía, aunque esta ya no tenga por qué recibir ese título" (2016, p. 14). En el próximo capítulo de esta investigación nos haremos una pregunta similar en torno a Benjamin.
} 
oír en esa inquietud algunos ecos benjaminianos, aunque las respuestas salgan disparadas desde allí como flechas en direcciones bien diferentes.

"La época de la imagen del mundo", cuyas principales ideas datan de 1938, resultará decisivo para confirmar algunas ideas presentes en el texto sobre la obra de arte. Heidegger reitera allí su alejamiento de la estética, a la que presenta como uno de los fenómenos fundamentales de la Edad Moderna: en efecto, cuando el arte se introduce en el horizonte de la estética, la obra se convierte en un mero objeto de la vivencia [Das Kunstwerk wird zum Gegenstand des Erlebens] (Heidegger, 2010, p. 63; GA 5 75), mientras que para Heidegger como para Benjamin- es posible ir más allá de esta caracterización.

Si bien en Benjamin este desborde será primordialmente político (en la tarea explícitamente enunciada de politizar el arte pero no sólo en ella), no deja de ser relevante la coincidencia en los términos, aun cuando se trate de una coincidencia parcial: la vivencia individual, que en Heidegger se identifica con concebir a la obra como "un objeto que debe provocar en nosotros determinados estados" (2016, p. 121), queda relegada al plano del mero consumo de arte, del disfrute y la apreciación de "lo formal en la obra" (Heidegger, 2016, p. 119), mientras que la experiencia como Erfahrung encarna una potencia transformadora en la medida en que el arte es capaz de abrir sentidos sin él clausurados. Así como en Simmel el paisaje es configurado como tal por el arte, y en Benjamin las calles de la ciudad se convierten en algo misterioso gracias al cine, en Heidegger lo corriente se ve modificado por el arte, que lo descubre en su verdad: "es un impacto que abre las vallas de lo inquietante e inseguro y así le da un vuelco a lo seguro y a todo lo que pasa por tal" (Heidegger, 2016, p. 131). Tanto es así que el arte tiene la capacidad de fundar historia, en tanto "siempre que acontece el arte, es decir, cuando hay un inicio, la historia experimenta un impacto, de tal modo que empieza por vez primera o vuelve a comenzar" (2016, p. 135). 
La conexión del arte con la historia que Heidegger establece en este texto no es de todos modos lineal ni sencilla, y así como es posible encontrar en ella algunos ecos de motivos benjaminianos, algunas alarmas comienzan a sonar cuando aparecen conceptos como el de pueblo y el de herencia, que parecen alejarse del cruce de caminos entre nuestros filósofos en una dirección peligrosa. No es nuestra intención indagar en esa dirección, sino más bien dar cuenta de que, así como Benjamin se refiere los cambios que experimenta nuestra sensibilidad como estando ligados al arte, también para Heidegger, "el arte es histórico" (2016, p. 135) y lo es en el "esencial sentido de que funda historia" (2016, p. 135).

Volvamos a "La época de la imagen del mundo". Allí, como argumentaremos, Heidegger aporta su mirada al fenómeno que nos ocupó en la primera sección de esta investigación, a saber, el de la estetización. Desde el comienzo, el texto presenta la tesis principal. En efecto, tras buscar la especificidad de la imagen del mundo moderno frente a la imagen del mundo medieval o antiguo, lanza a modo de preguntas las ideas fundamentales:

¿por qué nos preguntamos por la imagen del mundo a la hora de interpretar una época histórica? ¿Acaso cada época de la historia tiene su propia imagen del mundo de una manera tal que incluso se preocupa ya por alcanzar dicha imagen? ¿O esto de preguntar por la imagen del mundo sólo responde a un modo moderno de representación de las cosas? [Oder ist es schon und nur die neuzeitliche Art des Vorstellens, nach dem Weltbild zu fragen?] (2010, p. 72; GA 5 88)

Capturar la época en una imagen será descubierto como una pretensión propiamente moderna, que no sólo entra en relación con la reproducción como modo de aprehensión y de relación con el mundo, sino que va incluso más allá de ella. La imagen del mundo no es meramente "una especie de cuadro de lo ente en su totalidad [ein Gemälde vom Seienden im Ganzen]" (Heidegger, 2010, p. 73; GA 5 89), sino que, en palabras de Heidegger, 
allí donde el mundo se convierte en imagen [wo die Welt zum Bilde wird], lo ente en su totalidad está dispuesto como aquello gracias a lo que el hombre puede tomar sus disposiciones, como aquello que, por lo tanto, quiere traer y tener ante él, esto es, en un sentido decisivo, quiere situar ante sí [vor sich bringen und vor sich haben und somit in einem entschiedenen Sinne vor sich stellen will]. Imagen del mundo, comprendido esencialmente, no significa por lo tanto una imagen del mundo [ein Bild von der Welt], sino concebir el mundo como imagen [die Welt als Bild begriffen]. (2010, p. 74; GA 5 89)

Si bien el foco es novedoso, el motivo no es nuevo en Heidegger. Ya en Ser y tiempo y como pudimos exponer, el filósofo critica a la tradición moderna por privilegiar una relación con el mundo y las cosas en la que estas están disponibles para el hombre como centro de la creación. Allí, este entramado conceptual es desarticulado, como argumentamos, fundamentalmente con la redefinición de la experiencia en términos de un estar ya siempre formando parte de entramados de acción y lenguaje. Aquí, se apunta a desarticular justamente la absolutización de la experiencia moderna como la única forma de experiencia posible: desde la perspectiva de Heidegger, "en donde llega a darse la imagen del mundo, tiene lugar una decisión esencial [eine wesentliche Entscheidung] sobre lo ente en su totalidad. Se busca y encuentra el ser de lo ente en la representabilidad [Vorgestelltheit] de lo ente" (2010, p. 74; GA 5 89-90. El enfatizado es nuestro).

La configuración del mundo como imagen, lejos de ser meramente una conceptualización, estructura una forma de vida de la que la separación entre el hombre y el mundo y la comprensión del entorno como mero objeto son partes fundamentales. El mundo comienza a convertirse en imagen cuando "comienza ese modo de ser hombre que consiste en ocupar el ámbito de las capacidades humanas como espacio de medida y cumplimiento para el dominio [Bewältigung] de lo ente en su totalidad" (2010, p. 75; GA 5 92). En efecto, el proceso por el que el mundo se convierte en imagen es "el mismo proceso por el que el hombre se convierte en subjectum dentro de lo ente" (Heidegger, 2010, p. 75; GA 5 92). Y no solo en 
sujeto, sino en uno que pasivamente capta con los sentidos lo que lo rodea y tiene vivencias [Erlebnis]: tiene lugar, para recuperar la terminología que retoma Honneth, un olvido que es propio de la comprensión moderna del mundo. Zimmerman da cuenta de cómo, en Heidegger, la modernidad se presenta siempre ligada a las tecnologías que la signan ${ }^{213}$. La comprensión de esta tecnología moderna, a su vez, es tripartita: implica la industrialización -con sus sistemas, aparatos y técnicas propios-, la visión del mundo -cientificista, utilitarista- y la manera de comprender el entorno (Zimmerman, 1990, p. xv). En el reinado de la representación, del traer hacia sí y poner ante sí (Heidegger, 2010, pp. 75-76), el hombre es más unos ojos que ven que un sujeto actuante, en tanto cuando "el mundo se convierte en imagen, la posición del hombre se comprende como visión del mundo [Weltanschauung]" (2010, pp. 76-77; GA 5 93). Como el primo en la ventana al que se refería Benjamin en su estudio sobre Baudelaire, como aquel que, en Simmel, contemplaba el paisaje sin encontrar allí más que un cuadro, y no menos como quien recorre hoy el mundo buscando los mejores fondos para fotos de sí mismo, el hombre como centro de la creación es en la modernidad la medida de las cosas y el ojo que les da entidad.

Efectivamente, la crítica heideggeriana a la reducción de la experiencia a un encuentro con el mundo con poco potencial transformador lo acerca mucho al diagnóstico benjaminiano. Como Benjamin, Heidegger hace uso de categorías espaciales para dar cuenta de este fenómeno: se refiere a la "aniquilación de las grandes distancias [Vernichtung der großen

\footnotetext{
${ }^{213}$ Esto no es exclusivo de la filosofía de Heidegger, en tanto la reflexión sobre la técnica impregna los debates de la época, y cristaliza fundamentalmente en el debate Technik/Kultur o el "debate de Weimar". En su reconstrucción de este debate, que da lugar a posiciones tanto tecnofóbicas como tecnofílicas, Parente destaca que el proceso de industrialización de Alemania "se ha caracterizado por su aceleración, en contraste con el desarrollo gradual alcanzado en otros países europeos" (2010a, p. 140). En dicho contexto, "el debate no hizo más que poner en escena la paradójica condición de la técnica como factor de progreso, pero a su vez como elemento de desestabilización de la tradición y sus valores "culturales"” (2010a, p. 140). El movimiento völkisch, por ejemplo, que incluye autores como Julius Langbehn y Moeller van der Bruck y defiende el arraigo y la tradición y condena la modernidad, surge en este contexto (Zimmerman, 1990, p. 8). La importancia de este debate en el clima cultural de la Alemania de la primera mitad del siglo XX es visible no solo en los debates filosóficos, teológicos o políticos (en personajes tan disímiles como Klages, Jünger, Simmel o Adorno), sino que se extiende también a discusiones entre ingenieros, arquitectos y científicos, tanto en torno a la primera y la segunda guerra como en torno a la reconstrucción de Alemania tras 1945 (Parente, 2010a, p. 142; Zimmerman, 1990, p. 9 y ss).
} 
Entfernungen] gracias al avión" (2010, p. 77; GA 595) y a "la representación en toda su cotidianidad, ducida a placer y sin ningún esfuerzo, de mundos extraños y lejanos [fremder und abgelegener Welten] gracias a la radio" (2010, pp. 77-78; GA 5 95). Si bien Heidegger habla de la representabilidad, algo de la reproductibilidad técnica benjaminiana se cuela en su forma de referirse a la posibilidad de acercar imágenes y sonidos.

En su análisis, las cosas están cada vez más cerca, pero lo están como objetos: en la imagen y para el hombre, en una disponibilidad que les niega agencia, profundidad y potencia transformadora. Es por esto que la crítica a la reducción del mundo a mera imagen lleva, en este texto, a la siguiente crítica al humanismo como "aquella interpretación filosófica del hombre que explica y valora lo ente en su totalidad a partir del hombre y para el hombre [die vom Menschen aus und auf den Menschen zu das Seiende im Ganzen erklärt und abschätzt]" (Heidegger, 2010, p. 76; GA 5 93):

Cuanto más completa y absolutamente esté disponible el mundo en tanto que mundo conquistado, tanto más objetivo aparecerá el objeto, tanto más subjetivamente o, lo que es lo mismo, imperiosamente, se alzará el subjectum y de modo tanto más incontenible se transformará la contemplación del mundo y la teoría del mundo [die Welt-Betrachtung und Welt-Lehre] en una teoría del hombre [einer Lehre vom Menschen], en una antropología. Así las cosas, no es de extrañar que sólo surja el humanismo allí donde el mundo se convierte en imagen [wo die Welt zum Bild wird]. (...) Por eso, el humanismo en sentido histórico estricto, no es más que una antropología estético-moral [eine moralisch-ästhetische Anthropologie]. (Heidegger, 2010, p. 76; GA 5 93)

En la época de la imagen del mundo, el hombre se autoerige como centro y el mundo se convierte en nada más que el lugar del que éste obtiene sus sensaciones, o en palabras de Heidegger, en esta configuración específica de la experiencia humana "lo ente sólo vale como algo que es, en la medida en que se encuentra integrado en esta vida y puesto en relación con 
ella, es decir, desde el momento en que es vivido [er-lebt] y se torna vivencia [Er-lebnis]" (2010, p. 77; GA 5 94). Si bien sería forzado suponer que en Heidegger se da la misma relación entre la vivencia [Erlebnis] y la experiencia [Erfahrung] que se da en Benjamin, sí es posible afirmar que la mera vivencia es por lo general rechazada en tanto falta de una potencia y profundidad mayores que las que aportan a la vida humana las sensaciones.

A su vez, y esto es importante también para las reflexiones metodológicas de Heidegger, la época de la imagen del mundo, en su afán de medida, tiende a imponer un orden a todo aquello que somete a su control o, como anota Heidegger en uno de los apéndices del texto: "A la esencia de la imagen le corresponde la cohesión, el sistema [Zum Wesen des Bildes gehört der Zusammenstand, das System]"(2010, p. 81; GA 5 100).

En torno a la técnica pueden rastrearse algunas ideas cercanas a estas, que cristalizan en "La pregunta por la técnica", de 1954, pero que tienen antecedentes. Como expone Parente, “en los Beiträge comienza a gestarse la idea de Gestell, la esencia de la técnica como un modo de desocultación controlador" (2010a, p. 145). En efecto, la concepción heideggeriana de la técnica se caracteriza por el rechazo de la concepción meramente instrumentalista. Para Heidegger,

Por todas partes permanecemos presos, encadenados a la técnica, aunque apasionadamente la afirmemos o neguemos. Más duramente estamos entregados a la técnica cuando la consideramos como algo neutral; pues, esta concepción, que tiene hoy día gran aceptación, nos vuelve completamente ciegos para la esencia de la técnica. (1997, p. 113)

En efecto, el preguntar heideggeriano por la técnica parte, como es habitual en su obra, de un cuestionamiento de la forma tradicional de comprenderla. Es así que una de las primeras conclusiones del escrito es que "la técnica no es, pues, simplemente un medio. La técnica es un modo del desocultar. Si prestamos atención a eso, entonces se nos abriría un ámbito distinto 
para la esencia de la técnica. Es el ámbito del desocultamiento, esto es, de la verdad" (1997, p. 121).

Según Parente, en dicho texto "la preocupación esencial de Heidegger no es tanto la destrucción causada por tecnologías concretas (la bomba atómica, la progresiva destrucción de la biosfera, etc.), sino más bien el antropocentrismo metafísico que subyace a la comprensión tecnológica del ser” (2010a, p. 158).

Si bien las concepciones de la técnica en Benjamin y Heidegger presentan diferencias muy marcadas, también es importante enfatizar que ninguno fue ingenuo en su forma de comprenderla, en tanto ambos evitaron la posición meramente instrumentalista y comprendieron la forma en que la técnica modifica sustancialmente la experiencia humana ${ }^{214}$.

Como veremos a continuación, algunos de estos motivos se repiten en las reflexiones sobre la historia: el pasado y la tradición adquieren una densidad que no permite pensarlos como meros objetos de un sujeto que los domina a voluntad. El afán de dominio, medida y sistema, que es cuestionado en torno a la técnica en tanto su comprensión instrumental se basa en que "se la quiere dominar" (Heidegger, 1997, p. 115), es cuestionado también en torno a la relación con el pasado, en favor de nuevas formas de operar en las que el objeto mismo adquiere prelación frente al reinado del sujeto, que se corre del centro. En este sentido, también en dicho ámbito Heidegger y Benjamin se encuentran, como supo ver ya el berlinés. Allí, tal y como en relación al arte y como tendremos oportunidad de enfatizar, algunas coincidencias relevantes en torno a la crítica de la forma tradicional de comprender el tiempo y la historia darán lugar a diferencias considerables en la propuesta de aquello que plantean construir o las tareas que indican para su presente.

\footnotetext{
${ }^{214}$ Respecto de la relación de Heidegger con otro avance técnico importante, a saber, el de los medios de comunicación, resulta muy interesante el análisis que realizan Gunkel y Taylor (2014), y fundamentalmente su defensa de la productividad de las ideas del autor para pensar los medios de comunicación en la actualidad.
} 


\subsection{Historia, temporalidad y modos de experimentar el pasado}

La preocupación por repensar el tiempo, la historia y el pasado forma parte de los proyectos filosóficos tanto de Benjamin como de Heidegger, y lo hace no sólo en tanto tema sobre el que es menester meditar, sino también de modo transversal en las reflexiones sobre el arte, en la lectura de la tradición filosófica y en el análisis mismo de la época en la que viven. En efecto, la atención a la relación con el pasado y a los modos de comprender el tiempo forman parte, en ambos casos, del esfuerzo de los autores por comprender las modificaciones en la experiencia que signan la época.

En Heidegger y como pudimos ver a lo largo del capítulo, la preocupación por el modo de relacionarse con la tradición y de comprender la configuración propia de la modernidad son centrales (Rivera y Stuven, 2008, p. 17): la intención de leer lo aún no dicho en la historia de la filosofía destierra toda pretensión de objetividad y toda ilusión de neutralidad, reconociendo en el pasado a un interlocutor y no a un mero objeto, y lo mismo ocurre con el análisis de las obras de arte.

Asimismo, Heidegger comparte con Benjamin el afán de comprender históricamente la propia época. En sus palabras:

El hombre no podrá llegar a saber qué es eso que está vedado ni podrá meditar sobre ello mientras se empeñe en seguir moviéndose dentro de la mera negación de su época [der bloßen Verneinung des Zeitalters]. Esa huida a la tradición [Flucht in die Überlieferung], entremezclada de humildad y prepotencia, no es capaz de nada por sí misma y se limita a ser una manera de cerrar los ojos y cegarse frente al momento histórico [das Augenschließen und die Verblendung gegenüber dem geschichtlichen Augenblick]. (2010, p. 78; GA 5 95-96)

A su vez, ya en torno a la historia como tema, cabe señalar que tanto Benjamin como Heidegger ligaron sus análisis de la historia a una investigación del concepto de tiempo como 
aquello que está a su base, y que ambos pusieron en marcha un importante trabajo de destrucción de la concepción dominante del tiempo. En torno a esta cuestión sostuvo Agamben:

Por cierto no es casual que cada vez que el pensamiento contemporáneo llegó a pensar de manera nueva el tiempo haya debido empezar necesariamente con una crítica del tiempo continuo y cuantificado. Crítica que es el fundamento del que provienen tanto las Tesis sobre la filosofía de la historia de Benjamin como el análisis de la temporalidad ${ }^{215}$ que Heidegger no alcanzó a llevar a cabo en El ser y el tiempo. La coincidencia entre dos pensadores tan alejados es uno de los signos de que la concepción del tiempo que dominó por casi dos mil años la cultura occidental está llegando a su ocaso. (2011, p. 147)

En este mismo sentido, en un trabajo sobre Benjamin y Heidegger, Naishtat aporta información muy relevante del contexto en el que surgen los cuestionamientos de estos dos pensadores al modo tradicional de comprender el tiempo y la historia. Nos permitiremos citarlo in extenso:

El surgimiento de la teoría de la relatividad (1905), con su destrucción del tiempo newtoniano y de la idea correlativa de simultaneidad absoluta, y la aparición coetánea de la mecánica cuántica, cuyo principio de indeterminación desafió seriamente la idea de determinismo causal en el único reducto en el que éste podía todavía esperar seguir ejerciendo un dominio pleno, reforzaron la desestabilización de la idea heredada de tiempo. Por otra parte, la filosofía y las ciencias del espíritu (Geisteswissenschaften) venían experimentando, desde el último tercio del siglo XIX, una crisis de la idea homogénea y continua de tiempo: la noción del instante en Kierkegaard y en el último Nietzsche, la noción de la duración (durée) en Bergson, la Nachträglichkeit (posterioridad, "après-coup”) freudiana, la rememoración y la memoria involuntaria en Proust, el tiempo interior de la fenomenología en Husserl, desestabilizan la imagen de tiempo como algo

\footnotetext{
215 Sobre el análisis heideggeriano de la temporalidad, y la diferencia entre las nociones de Temporalität y
} Zeitlichkeit, puede consultarse Greisch (2010, p. 97). 
homogéneo, continuo y vacío, cuestionando tanto el concepto aristotélico de tiempo como medida del movimiento, cuanto la idea kantiana del tiempo, comprendido como forma pura y a priori de la sensibilidad, es decir, como contenedor formal de la experiencia. (2017b, pp. 4-5)

Para el caso de Benjamin, hemos dado cuenta de su cuestionamiento del tiempo en el capítulo 3 de esta investigación. En el caso de Heidegger, nos centraremos a continuación en aquel texto donde la reflexión sobre el tiempo está ligada a, y puesta en función de, una reflexión sobre la historia, a saber, la disertación "El concepto de tiempo en la ciencia histórica" [“Der Zeitbegriff in der Geschichtswissenschaft”] ${ }^{216}$, que pronunció en 1915 en la Facultad de Filosofía de la Universidad de Friburgo ${ }^{217}$. Nos referiremos asimismo a algunos pasajes del tratado El concepto de tiempo [Der Begriff der Zeit], de 1924, donde aparecen ya algunas ideas acerca de la temporalidad del Dasein que encontraremos desarrolladas posteriormente en $\mathrm{Ser}$ y tiempo.

En el texto de la conferencia de 1915 Heidegger diferencia el concepto de tiempo que utiliza la física de aquel del que se vale la historia, partiendo de los objetivos propios de estas $\operatorname{ciencias}^{218}$. La física tiene como objetivo subsumir las manifestaciones de las que se ocupa bajo una ley; apunta a lograr "la unidad de su imagen del mundo físico [die Einheit des physikalischen Weltbildes], reducir todos los fenómenos [aller Erscheinungen] a las leyes

\footnotetext{
${ }^{216}$ El texto fue publicado en 1916 en el vol. 161 de la Zeitschrift für Philosophie und philosophische Kritik, donde Benjamin lo leyó ese mismo año, como documenta la lapidaria crítica que dirige al texto en una carta a Scholem del 11 de noviembre de ese año. Como mencionamos en la introducción a este capítulo, Benjamin sostiene allí que lo que Heidegger sostiene sobre el tiempo histórico no tiene sentido, y lo acusa a su vez de estar equivocado también sobre el tiempo mecánico.

${ }^{217}$ Naishtat recuerda que alrededor de esa fecha tiene lugar también la conferencia de Georg Simmel en la sección berlinesa de la sociedad kantiana (Kantgesellschaft), más precisamente el 3 de marzo de 1916, titulada "Erkenntnistheorie der historischen Zeit" ("Teoría del conocimiento del tiempo histórico"). A su vez, rescata que en 1916 Benjamin redacta "Trauerspiel und Tragödie" y "Die Bedeutung der Sprache in Trauerspiel und Tragödie" (2017b, p. 5). Walter Benjamin se refiere críticamente, como indicamos en el capítulo 2, en una carta a Gershom Scholem (ca. 25 de diciembre de 1917), al texto de la conferencia Simmel, que se encuentra publicado en el tomo XV de su obra reunida como "Das Problem der historischen Zeit".

${ }^{218}$ Según apunta Caygill, este punto de partida del texto da cuenta de la asunción, por parte de Heidegger, de postulados neokantianos, entre los que se cuenta la distinción entre ciencias naturales y culturales tanto como la apuesta metodológica por evaluar la función de un concepto en función de su adecuación a los fines de la ciencia en cuestión (Caygill, 1994, p. 4).
} 
fundamentales y matemáticamente fijadas de una dinámica general” (Heidegger, 2009, p. 22) y tiene, por eso, la necesidad de homogeneizar los fenómenos sobre la base de un mismo parámetro. El fenómeno por excelencia del que se ocupa esta ciencia es el movimiento de los cuerpos, que trata de medir y comparar, y "los movimientos como objetos de estudio de la física se miden con ayuda del tiempo [mit Hilfe der Zeit]" (2009, p. 25). En este contexto, el tiempo, que aparece como posibilitando la medición de los movimientos, se caracteriza por su homogeneidad. Heidegger afirma que en el ámbito de la física

se presupone el tiempo como una variable independiente [unabhängige Veränderliche], de tal manera que éste (...) fluye uniformemente de un punto a otro sin saltos [ohne Sprünge]. El tiempo representa una serie [eine Reihe] que apunta en una dirección en la que cada punto del tiempo, medido desde el punto de partida, sólo se diferencia por su posición. (Heidegger, 2009, p. 26. El enfatizado es nuestro)

Para las ciencias naturales, en fin, el tiempo es homogéneo y cuantitativamente determinable y funciona como un parámetro con el cual medir el movimiento, que ocurre "en" el tiempo [in der Zeit], tal y como si este fuera una cuarta dimensión que se agrega a las tres dimensiones del espacio $^{219}$.

Ahora bien, ¿puede pensarse la historia con esta concepción del tiempo? Ya conocemos la respuesta de Benjamin a esta pregunta -que abordamos en el capítulo 3-, y su subsecuente esfuerzo por dar lugar a otra forma de comprender el tiempo, la historia y el pasado. En el caso de Heidegger, la respuesta también será negativa: “el concepto de tiempo de la ciencia histórica no guarda ninguna relación con el carácter homogéneo del concepto de tiempo de la ciencia natural [hat somit gar nichts von dem homogenen Charakter des naturwissenschaftlichen

\footnotetext{
${ }^{219}$ Sobre este punto es interesante el aporte de Agamben, para quien el pensamiento de la historia siempre se encuentra de algún modo espacializado. En sus palabras: "Dado que la mente humana capta la experiencia del tiempo pero no posee una representación de ella, necesariamente el tiempo es representado mediante imágenes espaciales" (2011, p. 130).
} 
Zeitbegriffes]" (Heidegger, 2009, p. 36). Dicho esto, resta investigar entonces, con Heidegger, “qqué estructura debe tener el concepto de tiempo propio de la ciencia histórica para que pueda funcionar, como concepto de tiempo, de una manera que corresponda a la finalidad [Ziel] de esta ciencia?” (2009, p. 18).

Ante el rechazo del concepto de tiempo que ofrece la ciencia natural, Heidegger se dirige hacia la ciencia histórica existente. Lo que allí encuentra es que, pese a que en un sentido el tiempo funciona en la historia también para ordenar los acontecimientos, esta no es su función principal. En efecto, el dato de la fecha en que algo ocurrió no es en sí mismo un conocimiento histórico $^{220}$, sino que lo propio de la historia es, en todo caso, recuperar el contexto en que los acontecimientos tuvieron lugar. Lo relevante no es el año como quantum, en el sentido de la ordenación temporal, sino el resto de los hechos que tuvieron lugar mientras ocurría el suceso que estamos estudiando, esto es, cómo era ese tiempo cualitativamente. Y es que en la historia los tiempos, en el sentido de épocas, son cualitativamente diferentes unos de otros, y no se diferencian solamente por ocupar un lugar diferente en la línea temporal. Así lo expone Heidegger, tomando prestadas palabras de Bernheim: "cada tiempo encierra en todas sus creaciones y expresiones [Schöpfungen und Äußerungen] un carácter que lo distingue del carácter de otros tiempos y que, además, estamos en disposición de conocer bien"221 (2009, p. 34).

Los años, en este sentido, no interesan al historiador como cantidad, sino que se usan para significar una época a la que se le atribuyen determinadas características, como es el caso de "el Quattrocento". En efecto, cuando se pregunta por el cuándo de un acontecimiento histórico, lo que importa es el contexto histórico. El carácter cualitativo del tiempo histórico también se hace evidente en la medida en que el inicio del tiempo está cualitativamente

\footnotetext{
${ }^{220}$ La figura del cronista, que Benjamin recupera, pondrá en jaque este desprecio de la labor de registro fechado de acontecimientos.

${ }^{221}$ Se trata, en efecto, de una cita del Manual del método histórico del historiador alemán Ernst Bernheim, editado en 1908.
} 
determinado: comenzamos a contar los años a partir de un acontecimiento que resulta relevante no por su ordenación sino por su contenido.

Para el Heidegger de 1915, el objeto de estudio de la historia es el hombre "que realiza la idea de cultura [die Idee der Kultur] a través de sus producciones espirituales y corporales" (2009, pp. 29-30), esto es, "la objetivación del espíritu humano [die Objektivation des menschlichen Geistes]"' (2009, p. 30). Sin embargo, el filósofo es consciente de que no es algo evidente ni obvio cuáles sean las producciones culturales que hay que retener de una determinada época, y de que la historia no caracteriza una época teniendo en cuenta todo lo que en ella sucedió: el historiador recupera, de "otro tiempo", solo algunos acontecimientos. La selección depende, dirá Heidegger citando a Eduard Meyer, “del interés histórico que el presente tiene en algún efecto, en el resultado del desarrollo [einem Ergebnis der Entwicklung]" (2009, p. 30) y -agrega Heidegger ya con sus palabras- "un interés siempre está determinado por un punto de vista [Gesichtspunkt]" (2009, p. 30).

Un punto central en la argumentación del joven Heidegger es que el pasado, al que la ciencia histórica mira, "en sentido estricto ya no existe más [er existiert streng genommen nicht mehr]" (2009, p. 31), y sólo puede cobrar relevancia a partir del interés que se tenga en él desde el presente. El tiempo pasado, para Heidegger, sólo puede estar presente cuando el presente lo convoca y es, a su vez, algo diferente de lo que hoy somos. Esta diferencia cualitativa de los tiempos, ese reconocer que antes se era de otra manera, que Heidegger llama "sentido histórico [historische Sinn]” (2009, p. 31), será justamente la base de la ciencia histórica que, lejos de observar el sucederse de un tiempo tras otro, tiene como objetivo comprender desde el presente otros tiempos cualitativamente diferentes del presente.

Ahora bien, dicha comprensión del pasado es posible porque la distancia temporal [Zeitferne] que nos separa de él puede ser franqueado por el historiador, que tiene que "superar el tiempo [die Zeit überwinden], (...) traspasar el abismo temporal [zeitliche Kluft] para 
sumergirse en el pasado desde el presente [sich von der Gegenwart in die Vergangenheit einzuleben]" (Heidegger, 2009, p. 31), esto es, ir desde el tiempo actual hacia otro tiempo para comprenderlo y ser capaz de elaborar su relación con el tiempo actual, que no está mediada por ninguna ley. En este sentido, Heidegger advierte que, mientras que en las ciencias naturales la ley es la meta a alcanzar, en la historia no hay ni puede haber una ley que determine cómo se sucederán las épocas. Con esta afirmación, parece alejarse de cualquier interpretación teleológica de la historia que vea en la sucesión de las épocas históricas el desarrollo lineal de la humanidad hacia un objetivo último ${ }^{222}$.

Entendemos, con Caygill, que esta manera de entender la relación entre el presente y el pasado tiene ya en ciernes una manera diferente de comprender el tiempo (Caygill, 1994, p. 6), en tanto el pasado no está ahí a la espera de ser conocido por un sujeto que lo examina, sino que es algo de lo que el presente debe -de algún modo- ocuparse. En este sentido, y pese a que el pasado ya no existe, sigue estando ahí como tiempo cualitativamente diferente. La función del tiempo en la ciencia histórica se releva paradójica, en la medida en que separa los tiempos cualitativamente diferentes, inconmensurables en un sentido, y a la vez posibilita que el historiador recorra los tiempos históricos en la medida en que el pasado no ha acabado de pasar (Caygill, 1994, p. 6 y p. 13).

En Ser y tiempo algunos de estos motivos reaparecen, pero lo hacen bajo la órbita de la analítica del Dasein. Allí, aparece con más fuerza el centro sobre el que se juega la relación entre el pasado y el presente en el análisis de la temporalidad que despliega Heidegger, a saber, el futuro. En efecto, la dimensión del proyecto, alrededor del cual gravita el pensamiento de

\footnotetext{
${ }^{222}$ Kordela (2015) recupera los trabajos de Comay y Caygill para relacionar a Benjamin y a Heidegger a través de Marx y Lacan. En realidad, Benjamin se acercará a estos pensadores y Heidegger quedará en las antípodas. La mirada y el fetichismo de la mercancía acercarán a Benjamin y a Marx, en tanto en ambos aparece una indeterminación de los sujetos y los objetos: en el antihumanismo de Benjamin las cosas devuelven la mirada, siendo en alguna medida agentes. En Marx, la mercancía es antropomorfizada en un intento del hombre de no volverse consciente de su propio carácter de objeto. Por otro lado, y mientras que Benjamin se aproxima a Lacan en su certeza de que siempre hay un exceso inconsciente en la historia, Heidegger queda sospechado de hegelianismo por su creencia en la posibilidad del advenimiento de la conciencia plena y por su tratamiento de la autenticidad.
} 
Heidegger, como es posible observar también en el tratado de 1924, transforma al presente en el momento de la decisión, que debe lidiar con el pasado ${ }^{223}$, apropiarse de él o rechazarlo. Naishtat apunta al respecto que "es porque el Dasein puede proyectarse y salirse de sí mismo, que está al mismo tiempo siendo su pasado, y anticipando su futuro, pero de modo que es el estar proyectado (Entwurf) la posibilidad misma de ese estar siendo su pasado" (2017b, p. 15).

Como aporta Agamben, la novedad que introduce el análisis presente en Ser y tiempo es que

la fundación de la historicidad se efectúa a la par de un análisis de la temporalidad que elucida una experiencia diferente y más auténtica del tiempo. En el centro de esa experiencia ya no está el instante puntual e inasible en fuga a lo largo del tiempo lineal, sino el momento de la decisión auténtica en el que el Ser-ahí obtiene la experiencia de su propia finitud que en toda ocasión se extiende del nacimiento a la muerte. (2011, pp. 148, 149)

En el análisis de Caygill, este eje en el proyecto del Dasein recentra la atención de Heidegger en el ser humano, mientras que Benjamin se rehúsa a caer nuevamente en ese esquema (1994, p. 13). En efecto, el énfasis en el modo en que el Dasein experimenta el tiempo en su propia vida en tanto Ser-para-la-muerte dista mucho de la perspectiva de Benjamin, en la historia se separa de la experiencia individual para convertirse en una experiencia colectiva de salvación del pasado.

En El concepto de tiempo 224 , el tratado de 1924, Heidegger se propone “comprender la historicidad" (2012, p. 5). Y es que, en efecto, en este trabajo Heidegger presenta muchas de

\footnotetext{
${ }^{223}$ En la perspectiva de Caygill, de lo que se trata es de una consideración diferente de la tradición que se despliega en la misma época en Ser y tiempo y en El origen del drama barroco alemán (Caygill, 1994, p. 13).

${ }^{224}$ Heidegger escribe este texto, como manifiesta al inicio, en ocasión de la publicación de la correspondencia entre Wilhelm Dilthey y el conde Paul Yorck de Wartenburg, de la que destaca el interés común por la historicidad. Heidegger aclara en el texto que el centro será Dilthey, porque en su caso "se dispone de amplias y detalladas investigaciones" (Heidegger, 2012, p. 7) mientras que en el de Yorck "sólo se conocen reflexiones aisladas y tesis por lo común de carácter general, que nacen de forma un tanto dispersa, fruto del trabajo realizado en compañía de su amigo" (Heidegger, 2012, p. 7); aun así, las reflexiones de Yorck son centrales y parecen expresar en algunas ocasiones las opiniones del mismo Heidegger.
} 
las ideas que desarrollará luego en Ser y tiempo, como queda en evidencia en el siguiente pasaje en el que explicita el camino a seguir: "La constitución ontológica fundamental del Dasein, a partir de la cual resulta posible aprehender ontológicamente la historicidad, es la temporalidad. De esta manera, la tarea de comprender la historicidad nos conduce a la explicación fenomenológica del tiempo" (2012, p. 6).

Tanto allí como en Ser y tiempo, el tratamiento del futuro que se desarrolla en el texto lo muestra ya como la dimensión más relevante para vislumbrar el modo en que el autor comprende la relación entre el pasado y el presente, en tanto funciona en algún sentido como un mediador. El Dasein, como ser de posibilidades, debe decidir y lo hace proyectándose hacia un futuro, anticipándose a él. Heidegger distingue, en Ser y tiempo, entre una temporalidad propia y una impropia, siendo la temporalidad propia aquella en la cual el Dasein proyecta sus posibilidades por medio de la resolución [Entschlossenheit $]^{225}$, y la temporalidad impropia aquella en la que se entrega al mero acontecer. A su vez y como menciona Safranski, el cuidado se relaciona a su vez con el futuro, en tanto "sólo puede estar cuidando un ser que ve ante él un horizonte de tiempo abierto (...). Nosotros somos seres que cuidamos y procuramos porque experimentamos explícitamente el horizonte temporal abierto hacia delante" (2003, p. 194).

La dimensión del futuro, en este sentido de proyectarse hacia posibilidades propias, será la que determine, finalmente, cómo se resuelve la relación entre el pasado y el presente. El sujeto histórico auténtico ${ }^{226}$ será el que es capaz de elegir su propio pasado (Caygill, p. 16) y proyectar su propio futuro. También así lo entiende Picotti, que comprende al pensar heideggeriano como teniendo la potencia de "poder percibir la historia como acaecer del ser en

\footnotetext{
${ }^{225}$ Siguiendo a Escudero, la resolución es "un modo de ser por el que el Dasein actúa una vez escucha la llamada de la conciencia y se decide libremente a ser sí mismo, es decir, en la resolución el Dasein se comprende desde su ser posible más propio" (2008, p. 86).

226 Caygill sostiene que esta apuesta por el sujeto para pensar la tradición arroja la idea de un "sujeto de la tradición" que puede ser el héroe, el poeta, el líder o el pueblo (1994, p. 17).
} 
la síntesis siempre renovada del pasado como espacio de experiencia, actualizable en el presente, desde las posibilidades abiertas por la proyección del futuro" (2010, p. 11).

Como mencionamos en la introducción a este capítulo, Benjamin conoció el trabajo de Heidegger sobre el tiempo de 1915, y en una carta a Scholem fechada en 1916, dice sobre él: "Un trabajo espantoso (...). La mayor parte de lo que el autor dice sobre el tiempo histórico no tiene sentido" (citado por Ibarlucía, 2000, p. 113). Aun así, pese a la contundencia de la crítica de Benjamin es posible encontrar, entre las reflexiones de Heidegger y las suyas propias, algunas continuidades.

Hay, en principio, dos elementos de la crítica benjaminiana a la ideología del progreso que creemos que tocan muy de cerca ideas heideggerianas presentes ya en 1915. Por un lado, el rechazo de la teleología en la escritura de la historia: ambos se oponen en principio a pensar la vida humana como acercándose a un fin prefijado, en la medida en que en sus filosofías dan un lugar central a la acción. Por otro lado, comparten también el rechazo de la comprensión del tiempo como un simple fondo sobre el cual se ordenan los sucesos, o como un saco dentro del cual se colocan. Para ambos, en fin, el tiempo no puede reducirse a un parámetro en la medida en que tiene un contenido cualitativo. Es lo que señala Caygill cuando observa que Benjamin y Heidegger acuerdan en que "el tiempo no es simplemente una unidad de medida con la cual se pueda medir la duración de una alteración mecánica" (Caygill, 1994, p. 9).

En este sentido, sus críticas se dirigen a una misma concepción del tiempo y de la historia, que no problematiza la temporalidad lo suficiente y simplemente plantea al tiempo como un homogéneo trasfondo para la vida humana. Ibarlucía sostiene al respecto que "Heidegger y Benjamin fueron por igual hostiles a la idea liberal de progreso, pero tuvieron concepciones radicalmente opuestas de la temporalidad histórica” (2000, p. 113). En efecto, tanto las cercanías como las diferencias en el modo de pensar la historia de los dos autores se juegan en la manera de establecer la relación entre el pasado y el presente, que da lugar en 
ambos a una reflexión sobre la tradición. Como sostiene Caygill, "para Heidegger y Benjamin (...), la tradición no era la transmisión fluida e ininterrumpida del pasado al presente, sino un traspaso de la tradición plagada de peligros y riesgos" (1994, p. 12). Sin embargo y como remarca Caygill, Benjamin no apunta a una relación auténtica con la tradición, como Heidegger, en tanto para él no puede haber una tal relación dentro de la tradición, sino sólo fuera de ella, tras su ruptura (1994, p. 18).

A su vez, los autores se diferencian en el estatus si se quiere ontológico que otorgan al pasado mismo. Mientras que en Heidegger el pasado - ese otro tiempo del que nos separa un abismo- es comprendido por un presente que se apropia de él, en Benjamin el pasado clama por ser redimido. A su vez, no es el presente el que debe tomar la decisión de "traer" al pasado, sino que este mismo asalta al sujeto en el presente, adviene, se presenta sin que el sujeto desdibujado, despojado de intencionalidad- tenga tanto control sobre ese advenimiento.

Es importante destacar que los autores coinciden en que la relación entre el pasado y el presente no es lineal, en el sentido de que el presente no viene simplemente luego del pasado y lo continúa, sino que debe trabajar con él. Ahora bien, en la filosofía de Heidegger las dimensiones temporales mantienen su naturaleza, en la medida en que el pasado es algo que podemos recordar, usar, pensar, conocer, pero sigue siendo algo que ya no es y que sólo puede ser útil en el presente para la proyección de un futuro. El pasado ya pasó, y sólo es recuperable mediante un interés del presente viviente en su recuperación ${ }^{227}$. En Benjamin, contrariamente, el pasado está en el presente, los muertos están en alguna medida entre nosotros y esperan algo de nosotros. En su filosofía, la linealidad de las dimensiones tradicionales del tiempo se quiebra, y es reemplazada por una catástrofe única que es necesario interrumpir.

\footnotetext{
${ }^{227}$ Schwebel (2015) analiza esta diferencia en torno a las interpretaciones que ambos filósofos esbozaron de la monadología alrededor de 1928. Si bien ambos añaden tiempo a la unidad de Leibniz, mientras que para Benjamin la monada está plagada de un tiempo no cronológico, para Heidegger origina ella mismo el tiempo. Esta diferencia en la apropiación de las ideas de Leibniz se prolonga y profundiza, para la autora, en la obra de ambos hasta llegar a una comprensión radicalmente diferente del pasado, que es para Heidegger algo clausurado -que puede ser recuperado por el Dasein-y para Benjamin una instancia no clausurada que puede abrirse en la rememoración.
} 
No obstante esta diferencia general, hay algunos matices en la exposición que Heidegger realiza sobre el tiempo que parecen acercar más sus reflexiones a las de Benjamin. En Heidegger, ese otro tiempo que debemos conocer o comprender es, como vimos, también un pasado por elaborar por el Dasein, que debe proyectarse hacia el futuro. En este sentido, el pasado también está de algún modo en el presente en la forma de algo que hay que asumir y se resignifica o reinterpreta desde el presente. El historiador debe vencer el abismo temporal que lo separa del pasado y conectarse de algún modo con él.

Aun así, la radicalidad de la propuesta benjaminiana es mayor, ya que no apunta a recuperar o rechazar un legado para el presente (y su proyección), sino a una responsabilidad que el ahora tiene para con lo que ha sido en tanto eso que ha sido, y, más aún, lo que no ha sido, puede aún realizarse.

Heidegger propone una apropiación del pasado, pero para Benjamin el pasado no es apropiable porque no tiene carácter de objeto. Reyes Mate, comparando la postura de Benjamin con visiones más tradicionales de la historia, dice al respecto que "esta manera de ver las cosas se opone a la del historiador convencional que va al pasado pensando que está ahí, inmóvil, eterno, a merced de quien lo visite para alquilar sus servicios" $(2009$, p. 256).

La diferencia en la relación entre el pasado y el presente nos lleva a una diferencia en lo que el pasado es ontológicamente: algo que no está más o algo que sí, algo que tiene una fuerza que lo hace regresar y que nos exige, o algo acabado que podemos elegir usar o no usar, mirar o no mirar, según el futuro que queramos proyectar. Y es que mientras que en Heidegger el presente parece tener derechos sobre un pasado que le pertenece, que es $s u$ pasado, en Benjamin el pasado tiene derechos sobre el tiempo presente y sobre su débil fuerza mesiánica.

Finalmente, quizá la diferencia más importante entre sus reflexiones sobre la historia tiene que ver con que, mientras que Heidegger está criticando teóricamente un modo de comprender el tiempo histórico y reflexionando sobre la historia como ciencia y sobre el tiempo 
y la historicidad como elementos centrales en la vida del Dasein, Benjamin, que piensa la historia como una práctica revolucionaria, está denunciando ese mismo modo de ver el tiempo como políticamente peligroso, en la medida en que deja atrás a los vencidos de la historia.

\subsection{Consideraciones finales}

Quien alguna vez haya respirado aire urbano y perciba la relación entre espíritu $y$ polis no se dejará engañar: hay en Heidegger algo que nunca ha mudado, un horror al mundo, un furor del quedarse en casa.

Peter Sloterdijk, 2011, p. 34

Como hemos expuesto a lo largo del capítulo, mucho podría decirse -y mucho se ha dicho- de la relación entre Benjamin y Heidegger y de los modos en que debería ser atendida o dejada de lado. En nuestro caso, hemos intentado recuperar algunas preocupaciones comunes en torno a lo que en sentido amplio llamamos experiencia, esto es, en torno a la relación del hombre con el mundo, especialmente en torno a los ejes del arte y la historia. En ambos autores, estos ejes se amplían en dos direcciones: por un lado, en un análisis de la percepción sensible y de la temporalidad que indaga la construcción epocal de sensibilidades, narrativas y topografías que exceden lo estrictamente artístico o histórico para dar cuenta de formas de configuración de la vida. Por otro lado, el arte y la historia funcionan como puertas de entrada a reflexiones sobre la tradición y sobre la verdad, que se revelan a su vez como temas profundamente políticos que exceden la vivencia subjetiva del tiempo o de las obras y se adentran en debates sobre lo colectivo, donde los autores alcanzan su máximo grado de separación.

En este sentido, y tras haber dado cuenta del modo en que es posible leer transversalmente en la obra de Benjamin una preocupación persistente en torno a la gesta de 
una relación desapegada y estetizada con el entorno, relación que cristaliza en la coreografía del terror que pone en marcha el nazismo, nos concentramos a lo largo de este capítulo en trazar un recorrido por la obra de Heidegger que colecte allí las pistas de una inquietud análoga. En efecto, no es forzado decir que Heidegger fue un crítico lúcido e incansable de las formas de objetivación del mundo que lo comprenden, desde la teoría pero no sin consecuencias importantes para la praxis, como un mero objeto de observación, control y medida. Asimismo, este olvido configura una comprensión limitada del ser del Dasein como sujeto o mera conciencia que alcanza su auge en la modernidad como época de la imagen del mundo. La crítica heideggeriana de la estética se acerca, en este contexto, a su crítica a la comprensión vulgar del conocimiento: reduir el mundo a mera imagen y limitar a las obras a meras expendedoras de sensaciones para el hombre limita la agencia propia del mundo, que no casualmente se hace presente en la obra de arte en tanto ésta pone en obra una verdad.

Por último, la crítica al intento de pensar la historia a partir de la lógica de las ciencias naturales completa un cuadro en el que, más allá de innumerables diferencias, matices e intereses, puede leerse una preocupación integral por el modo en que el reinado del sujeto nos entrega a un ser aislado de su entorno que no parece encontrar casa y que se parece bastante para volver a la expresiva imagen de Benjamin- a ese contemporáneo desnudo que grita como un recién nacido en los sucios pañales de su época.

Nuestra propuesta fue hacer el ejercicio de pensar si es posible encontrar, también en Heidegger, allí en las antípodas políticas de Benjamin, a un filósofo preocupado por algo así como una crisis de la experiencia y algo así como una estetización, si no de la política, sí de la historia y hasta quizá del pensamiento, que la tradición no indaga en sus vacíos sino sólo en sus hitos. La respuesta que arroja este intento es ambigua: sobre una búsqueda que se asemeja, las motivaciones que se descubren como sus motores terminan explicando que lo encontrado se diferencie de manera tan radical. $\mathrm{O}$ en términos heideggerianos: "las respuestas solo 
conservan su fuerza como respuestas mientras siguen arraigadas en el preguntar" (2016, p. 125), y aquí el preguntar se revela como indiscernible de la posición de quien pregunta.

Como analizamos en torno a cada sección, la diferencia crucial es, en un sentido muy profundo, política. En efecto, y si bien Heidegger da cuenta de las transformaciones en el modo de relación con el mundo que opera la técnica, Benjamin va más allá y denuncia una crisis de la experiencia tras observar la experiencia de una generación diezmada por la violencia y la potencia destructiva que esa técnica despliega. Asimismo, cuando Heidegger nota que el mundo se ha convertido en un mero objeto, lo que implica una pérdida de espesor o profundidad, Benjamin redobla la apuesta y se refiere a cómo el espectáculo que observa la humanidad es el de su propia destrucción. Por último, mientras que Heidegger indica la tarea de asumir el propio futuro en la existencia propia, Benjamin apunta a una destrucción del continuo que ponga el freno de emergencia y escuche a los olvidados de la historia.

En este sentido, nos interesa, para terminar, indagar en las propuestas que laten en lo profundo de la obra de Benjamin y la de Heidegger. Si bien ninguno propuso un programa de acción, ambos indican tareas y, especialmente, indican tareas para la filosofía, que es en ambos, aunque no de la misma manera y como enfatizamos más arriba, una respuesta a la época que la gesta y a la tradición en la que se inserta.

Richter (2015), enfatiza, en su estudio sobre la relación entre los autores, la importancia que en la obra de ambos reviste el deseo de aproximarse rigurosamente a los fenómenos a través del lenguaje entendido como condición de posibilidad del pensar y da cuenta, desde allí, de un conjunto de preocupaciones comunes que se relacionan con ese deseo. Entre ellas, la recuperación del criticismo kantiano -y de la práctica de la crítica- en un ámbito diferente del neokantiano será clave. A su vez, comprendida como un compromiso de revisión y de reinvención de los propios métodos y enfoques ante cada nuevo objeto, la crítica será la llave que le permitirá a Benjamin habérselas con el mundo de las cosas. En Heidegger, la crítica 
tiene un papel menos protagónico o menos explícito. Aun así, su proyecto implica un cuestionamiento de formas osificadas de pensar y actuar que puede ser leído como una forma post-kantiana de crítica -es decir, no centrada en el sujeto-, que busca acercar el pensamiento a las cosas del mundo -las herramientas tanto como las obras de arte-. Para ambos, sostiene Richter, la crítica es parte de una política de la pregunta (2015, p. 57), que se aleja de ser un mero juicio y resulta una vía hacia la verdad.

En efecto, tanto Benjamin como Heidegger coinciden en centrar sus investigaciones en una búsqueda de las palabras, los formatos y las imágenes que les permitan dar cuenta de lo que perciben como peligroso en su época, si bien al hacerlo llegan a puertos distintos. La carrera y la vida de Benjamin terminan súbitamente entre escritos que superponen imágenes y textos breves que, por un lado, renuncian al dispositivo de la explicación y la taxonomía eligiendo mostrar y disponer en lugar de hilar en un continuo y, por el otro, exhortan a la acción. La vida y la obra de Heidegger se van alejando cada vez más del trabajo más sistemático de Ser y tiempo y naufragan en una búsqueda poética que se aleja de algunas de las intuiciones más agudas sobre la vida humana y la tradición filosófica que conforman, hasta la fecha, lo más comentado de su obra. En este contexto, las palabras de Adorno adquieren mucha relevancia:

Cada vez que la filosofía cree que, mediante un préstamo de la poesía, puede abolir el pensamiento objetualizador y su historia, según la terminología habitual la antítesis de sujeto y objeto, y espera que hable el ser mismo en una poesía montada a partir de Parménides y Jungnickel ${ }^{228}$, con ello no hace precisamente sino aproximarse a la más lixiviada cháchara cultural. (Adorno, 2003, pp. 15-16) ${ }^{229}$

Efectivamente, el Heidegger posterior a la Kehre elige, tras apuestas e intentos teóricos notables, abandonar la idea de que la filosofía tenga aún la potencia de transformarse desde

\footnotetext{
${ }^{228}$ Adorno se refiere en este pasaje al pintor Ludwig Heinrich Jungnickel, nacido en Viena en 1881.

${ }^{229}$ Respecto de esta crítica de Adorno puede consultarse Gómez (1996).
} 
dentro, en diálogo con su propia tradición, y se entregar a la potencia del pensamiento poetizante. Si bien las diferencias con el período de Ser y tiempo son notables, algo en el orden de las preocupaciones permanece inalterado. En efecto, el célebre escrito de 1927 permite ser leído, también, "como invitación a realizar un viaje interior, un viaje que siempre tiene algo de una odisea plagada de obstáculos y peligros, unos desconocidos y otros conocidos, que debemos sortear con éxito para conducir a buen puerto nuestra vida" (Escudero, 2012, p. 79). El viaje, en Heidegger, será siempre hacia adentro, y la lucha se dará siempre en el plano del sí mismo propio. En el caso de Benjamin, y si bien la desconfianza en la tradición filosófica para hacerse cargo de las tareas que son urgentes es notable, el viaje hacia la interioridad y hacia la poesía es reemplazado por una apuesta a lo colectivo y a una articulación con el arte que, sin salir de la filosofía, desdibuja sus márgenes generando espacios nuevos. Egel (2015) da cuenta de esta diferencia a través de un estudio comparativo de los trabajos de Benjamin y Heidegger sobre Hölderlin. Benjamin -a las puertas de la primera guerra mundial y tras el suicidio de dos amigos- elige dos poemas que lidian con la pregunta por el lugar del poeta en el mundo, y encuentra allí, para la autora, una nueva manera de comprender la poesía como una forma de muerte y la muerte -en un nuevo significado- como una forma de poesía (p. 179). Heidegger, por su parte y siempre siguiendo a Egel, encuentra la poesía de Hölderlin escapando de la política, huyendo tanto de su propia responsabilidad en el estado de las cosas como de las angustias que este le significaba, y se concentra en los poemas que refieren al movimiento y al tiempo. La diferencia que se demarca, radical, es que mientras Heidegger ve en la poesía una alternativa a la política (Egel, 2015, p. 183), Benjamin parece comprender, antes de denunciarlos explícitamente y como atendimos, los peligros de la estetización de la política ${ }^{230}$.

\footnotetext{
${ }^{230}$ En una línea parecida, Hodge (2015) parte también de poner en diálogo las lecturas que ambos autores hicieron de los poemas de Hölderlin. Atendiendo a aquellos entrelugares que se generan en las fronteras entre la poesía y la filosofía, y entre la religión y la política, la autora indaga las fuerzas que allí se tensan en tanto fuerzas que el poeta y sus dos lectores se esforzaron por descubrir o acaso, al menos, mostrar. Como parte de las preocupaciones conjuntas de estos tres pensadores, Hodge destaca la urgencia por complejizar la conceptualización de lo humano como tal y, específicamente, por imaginar qué será de lo humano tras las modificaciones de la experiencia de las
} 
Y es que la lucha es, en su caso, contra el fascismo, y la búsqueda apunta, lejos del perfeccionamiento de una interioridad individual o de un pueblo, nada menos que a la salvación de la humanidad misma. Como menciona Agamben, "cada concepción de la historia va siempre acompañada por una determinada experiencia del tiempo que está implícita en ella, que la condiciona y que precisamente se trata de esclarecer" (2011, p. 129). El tiempo que experimentaron Benjamin y Heidegger es y no es, como intentamos mostrar, el mismo: si bien ambos están atravesados por los peligros y las potencias propios de su tiempo, lo están de modos muy diversos.

que son -y, como se enfatiza en el texto, somos aún- testigos. En este contexto, dos elementos se develan centrales, a saber, por un lado, el lenguaje y, por el otro, lo monstruoso, como aquellos límites que la filosofía, la poesía y acaso también la política, no pueden evitar desafiar. 


\section{Capítulo 7}

\section{En busca de una escritura no estetizante ${ }^{231}$}

El buen escritor nunca dice más de lo que pensó. Asi su escritura no redunda en provecho de sí mismo sino exclusivamente de lo que quiere decir.

Walter Benjamin, 2011a, p. 153

\subsection{Introducción}

Habiendo realizado un recorrido por la filosofía de Walter Benjamin en torno a sus diagnósticos de un empobrecimiento de la experiencia y una estetización de la política y el pasado, que interpretamos como el desvelamiento de un proceso de museificación del mundo, nos interesa concentrarnos en este capítulo en los desafíos que esta situación arroja para el campo filosófico. Como vimos en el capítulo precedente, tanto Benjamin como Heidegger -y con ellos Simmel ${ }^{232}$ pero también Proust- pueden ser leídos como autores que, más allá de abordar temas, problemas y conceptos, ponen en marcha una búsqueda muy particular de modos de decir que sean capaces de mostrar las situaciones problemáticas, los peligros y las potencialidades propias de su presente.

En esta búsqueda, a nuestro entender, la filosofía contemporánea emula el modo de experimentación propio de las disciplinas artísticas: mientras que ya en los comienzos del siglo XX el arte se aleja de la tiranía de la imagen para acercarse al concepto y buscar allí modos nuevos de decir (Genette, 1997), cuestionando fuertemente su propia naturaleza, la filosofía -

\footnotetext{
${ }^{231}$ Una versión previa de este capítulo (Staroselsky, 2020a) fue publicada en Ágora. Papeles de Filosofía.

${ }^{232}$ Werner Jung (2016) da cuenta de cómo el modo de decir es muy relevante en Benjamin, Simmel y Lukács, en tanto "si la antigua cosmovisión se fracturó, simplemente, se tiene que contemplar el mundo de nuevo" (p. 107) y "ya no se puede tratar de reunir, falseándolos, estos fragmentos y escombros en una totalidad" (p. 108).
} 
de la mano de los autores mencionados- hace lo suyo, escapándose del marco del concepto que la caracterizó por más de dos mil quinientos años ${ }^{233}$. En Heidegger, y si bien no nos centraremos ya en él, esta búsqueda se sumerge en la poesía; en Benjamin, lleva a la experimentación con los formatos de escritura y la producción de imágenes. En ambos casos, los filósofos evitan hacer de la filosofía otro dispositivo estetizante, que proponga una maqueta del mundo explicada al detalle.

A su vez, el corrimiento, borramiento o cuestionamiento de los límites disciplinares se configura como un rasgo propio de la época contemporánea: como señala Néstor García Canclini, el arte asume sus funciones sociales, políticas y económicas y explora su capacidad de reflexionar acerca del mundo (2010, p. 29). Las ciencias sociales y la filosofía, por su parte, en el contexto de algunas de sus tradiciones, sofocadas por las estructuras y los métodos que las atraviesan, encuentran en el arte ya no sólo un tema o un objeto de reflexión, sino más bien un lugar al que ir a pensar. En efecto, el punto de partida de este capítulo será el escenario que arroja lo que García Canclini denomina "giro transdisciplinario intermedial y globalizado" (2010, p. 40).

En el caso del arte y como menciona Reinaldo Laddaga, lo que se explora, ya a partir de fin del siglo XVIII, es "la capacidad de las artes para proponerse como un sitio de exploración de las insuficiencias y potencialidades de la vida común” (2006, p. 8), y para esto se ponen en marcha "modos posdiscliplinarios de operar" (Laddaga, 2006, p. 19). Agregaremos que, en la filosofía, y particularmente en la obra de Benjamin, se da un movimiento similar, en tanto este filósofo es consciente de que nos encontramos "en medio de un enorme proceso de refundición de las actuales formas literarias [einem gewaltigen Umsdlmelzungsprozeß literarischer Formen], en el que muchas de las contraposiciones en las que estamos

\footnotetext{
${ }^{233}$ Cabe aclarar que esto es así en los autores mencionados, pero que, a diferencia de ellos, hay filósofos que podríamos decir- se aferran al concepto $\mathrm{y}$, al hacerlo, se limitan a un mero análisis del lenguaje. Bernstein, por ejemplo, en su estudio sobre el giro pragmático (2012), menciona que este es uno de los problemas de la filosofía analítica, que parece perder por esta vía contacto con el mundo.
} 
acostumbrados a pensar podrían ya perder toda su fuerza [viele Gegensätze, in welchen wir zu denken gewohnt waren, ihre Schlagkraft verlieren könnten]" (Benjamin, 2009b, p. 301; GS II 687).

En este contexto, nuestro objetivo es ofrecer, en este último capítulo, una lectura de Benjamin que se centre, no tanto en los motivos, sino en la encrucijada entre su estilo y su inscripción fronteriza en el campo académico (Naishtat, 2011). En efecto, y más allá de los temas y problemas que abordó, la originalidad y la fuerza de la filosofía de Benjamin se encuentran también en las formas que encontró de operar mecanismos de ruptura, destrucción y translocación, en su filosofar en los desvíos, rodeos, giros y cambios de foco, y en su trabajo con el lenguaje ${ }^{234}$. Estos aspectos formales se revelan, también, como una parte importante del modo en que Benjamin se inscribe en los debates académicos y políticos.

En un breve fragmento publicado en el tomo VI de su Obra completa, Benjamin ofrece la siguiente imagen:

Pensamiento y estilo [Gedanke und Stil]. El estilo es la cuerda [Sprungseil] que debe saltar el pensamiento para entrar en el reino de lo escrito. El pensamiento debe reunir, debe acumular, todas las fuerzas. Pero el estilo debe ir a su encuentro y relajarse, tal como sucede con la cuerda volteada por los niños cuando alguno está a punto de saltar [Gedanke und Stil. Der Stil ist das Sprungseil, das der Gedanke nehmen тuß, um ins Reich der Schrift vorzudringen. Der Gedanke muß alle Kräfte zusammenreißen. Aber der Stil ihm entgegenkommen und nachlassen, wie das Seil in den Händen der Kinder, welche es schwingen, wenn eines unter ihnen zum Sprunge ansetzt]. (2017g, pp. 282-283; GS VI 202)

\footnotetext{
${ }^{234}$ En este sentido, Naishtat ha destacado "el ímpetu anti-narrativo" de Benjamin, en tanto en su obra "la narrativa clásica, bajo sus categorías de héroe y de trama época y aleccionadora, con su pathos armonioso de reconciliación, se vuelve objeto de una crítica contundente" $(2008$, p. 2). Asimismo, sobre los giros en la filosofía, ver Naishtat (2010b).
} 
Si bien es difícil encontrar investigaciones sobre la filosofía de Walter Benjamin en las que no se destaque el carácter único de su estilo, es a su vez poco usual encontrar estudios que se centren en esta característica de su producción (Weber, 2008, p. 115). El modo de escritura de Benjamin suele mencionarse a título introductorio en investigaciones que indagan la constelación de conceptos, temas y motivos que pueblan su pensamiento (Lindner, 2011; Opitz y Wizisla, 2014), pero no ha sido estudiado de forma exhaustiva, aun cuando él mismo criticó el sesgo que privilegia el análisis conceptual y relega lo formal a mero aspecto secundario.

Entre las excepciones cabe mencionar a Kracauer (1999), a Bloch (1985) y a Adorno, quien atendió muy tempranamente al modo de exposición propio de la filosofía benjaminiana. En "El ensayo como forma", sostiene:

El cómo de la expresión tiene que salvar lo que de precisión se sacrifica cuando se renuncia a la circunscripción, pero sin entregar el asunto tratado a arbitrio de los significados conceptuales decretados de una vez por todas. En eso Benjamin ha sido el maestro insuperado. (2003, p. 22)

En este ensayo, Adorno da cuenta de una característica distintiva del ensayo en la que cabe detenerse: "El ensayo se sacude la ilusión de un mundo sencillo, lógico el mismo en el fondo, que tan bien se adapta a la defensa de lo que meramente es" (2003, p. 25). Asimismo, da cuenta del modo en que el ensayo es considerado como un género menor. En sus palabras:

A pesar de toda la grávida comprensión que Simmel y el joven Lukács, Kassner y Benjamin han confiado al ensayo, a la especulación sobre objetos específicos, culturalmente ya preformados, el gremio solo tolera como filosofía lo que se reviste con la dignidad de lo universal, de lo permanente, hoy en día si es posible de lo originario, y no se ocupa de una obra espiritual particular más que en la medida en que en ella se ejemplifiquen las categorías universales; en que al menos lo particular se haga transparente en ella. (2003, pp. 11-12) 
Benjamin opera con su obra, en efecto, dos movimientos: por un lado, pone en marcha una experimentación con diferentes formatos y soportes de escritura y pensamiento cuya continuación no puede buscarse en las revistas académicas, sino que invita a una excursión por otras geografías textuales: escribe ensayos, habla en la radio, construye aforismos breves, da charlas, escribe crónicas, piensa en cartas. Por otro lado, empuja los límites de la propia disciplina para ir a pensar a otros lugares: en efecto, es conocida la disputa entre Adorno y Arendt en torno a identificar a Benjamin como filósofo ${ }^{235}$, que se mueve entre el propio deseo de Benjamin de ser reconocido como crítico literario -"le premier critique de la littérature allemande", como le dice a Scholem en una carta de enero de 1930 (GB 505)-, y el hecho, que destaca Naishtat, de que si bien "se distanció en forma definitiva del ámbito académico, sus preocupaciones continuaron siendo de índole filosófica" (2011, p. 1).

En lo que sigue, entonces, nos referiremos a estos dos movimientos. A su vez, exploraremos la obra de Joseph Kosuth en tanto resulta productiva para poner en cuestión los modos tradicionales, disciplinares de operar, dando cuenta de algunas de las limitaciones que les son propias y de la potencialidad de ciertas formas de decir para generar experiencias no sólo interesantes sino también epistemológicamente valiosas.

En el primer apartado del capítulo, entonces, daremos cuenta, a partir de algunos textos de Benjamin, de cómo el rol y la tarea del filósofo lo colocan, en este nuevo escenario y como el propio Benjamin dice en el "Prólogo epistemocrítico" a El origen del Trauerspiel alemán, de $1928^{236}$, entre el investigador y el artista. A efectos de profundizar en la comprensión de dichos roles, en el segundo apartado abordaremos parte de la producción del artista conceptual Joseph Kosuth, quien vincula explícitamente su obra a la filosofía y que explora allí

\footnotetext{
${ }^{235}$ Para un análisis de dicho debate, y una exploración de la inscripción fronteriza de Benjamin en la filosofía académica, ver Naishtat (2011). Asimismo, Cohen (2009) recupera la figura de crítico para Benjamin, quien despliega "su saber filosófico (...) como crítica, sea literaria o filosófica, sin distinciones ni jerarquías" (2009, p. 139).

${ }^{236}$ Si bien El origen del Trauerspiel alemán se publica en 1928, es redactado por Benjamin en 1925 como tesis de habilitación docente.
} 
renovaciones posibles del lenguaje artístico. Específicamente, nos referiremos a "Berliner Chronik" de 1994, instalación en la que Kosuth se basa en la obra de Benjamin. Ello nos permitirá dar cuenta de la relación entre las propuestas teóricas y los modos de experimentación de ambos pensadores, que se preguntaron por los modos de proceder en sus disciplinas, y que recorren, de alguna manera, el mismo camino, pero lo hacen en direcciones opuestas: Benjamin operando una ruptura en la hegemonía del concepto en la filosofía y dirigiéndose hacia la imagen, y Kosuth encontrando en el concepto una vía para la desmaterialización del arte.

\subsection{El filósofo como productor ${ }^{237}$}

\section{Si el pensamiento del autor no puede estar al servicio de la experiencia,} la escritura queda como cosa impostada.

Liliana Villanueva y Hebe Uhart, 2015, p. 2019

Benjamin deja muy clara su posición con respecto al rol de los intelectuales y artistas en la sociedad en la conferencia titulada "El autor como productor" de $1934^{238}$. En este texto el filósofo hace, en sus propias palabras, una "crítica política literaria" [politischen Literaturkritik] (Benjamin, 2009b, p. 298; GS II 684) ${ }^{239}$ y comienza dando un paso cuya importancia no habría que perder de vista: se refiere a la escritura como actividad. Al hacerlo, desarticula categorías para pensar la producción artística/intelectual profundamente arraigadas, como los pares binarios forma-contenido de la obra o el que se abre entre la tendencia política

\footnotetext{
${ }^{237}$ Algunas de las ideas que desarrollamos en este apartado fueron exploradas en Melamed y Staroselsky (2017). ${ }^{238}$ Como se indica en la edición en español de Abada (Benjamin, 2009b, p. 297, nota I), y como indicamos brevemente en la introducción general de esta investigación, el título corresponde en realidad a una conferencia que Benjamin preparó para pronunciar en el Instituto para el Estudio del Fascismo durante su exilio en París, en 1934, pero cuya lectura finalmente no habría tenido lugar.

239 En Carrusel Benjamin, Mariana Dimópulos (2017) trabaja con la idea de crítica como género, en tanto actividad que encuentra su expresión en la prosa, que ha habitado los espacios de la reseña y la polémica y que implica un conocimiento específico del objeto del que se ocupa, mientras que el juicio meramente acepta o rechaza aquello con lo que entra en relación. Sobre la importancia de la crítica en la filosofía de Benjamin y su relación con la configuración de una nueva ilustración, ver Naishtat (2015).
} 
de la obra y su calidad, digamos, técnica, en un sentido que será bastante próximo al movimiento que realizará, como veremos más adelante, Kosuth en los años 60 para el plano de arte.

Asimismo, Benjamin hace un movimiento de cambio de foco: no se pregunta por el lugar que ideológicamente ocupan la obra o el autor (qué defiende, qué critica, si es, en su contenido o en su mensaje, reaccionaria o revolucionaria), sino que apunta a la posición de la obra como tal en las relaciones sociales de producción literaria. Hace foco, entonces, en la técnica, la hechura, en fin, en la producción. Este punto, como ampliaremos, también mantiene un cierto paralelismo con las ideas de Kosuth, para quien el arte conceptual fue aquel que logró, no ya decir cosas distintas con el mismo lenguaje, sino cambiar el lenguaje con el que tradicionalmente se producían significados.

Benjamin afirma en este texto que lo que determina el lugar del intelectual en la lucha de clases es su posición en el proceso de producción, por lo que éste debe trabajar no sobre su conciencia de clase sino sobre su técnica productiva. Sostiene, asimismo, que los géneros literarios/filosóficos son temporales e indica la necesidad de que sean repensados teniendo en cuenta las realidades técnicas de nuestra situación actual (Benjamin, 2009b, p. 301), en tanto la época está signada por un proceso de fusión en el que las formas tradicionales han perdido actualidad y potencia. Esta crisis de los géneros literarios y de los formatos que nos habían servido para pensar, sumada a la crisis de la experiencia diagnosticada sólo un año antes en "Experiencia y pobreza", a la que nos referimos fundamentalmente en el capítulo 4 de esta investigación, no es más que el trasfondo en el marco del cual Benjamin desarrolla su propia obra, que se despliega como una búsqueda de dar respuesta a esta situación desde la práctica, y más aún, desde la técnica literaria, desde la experimentación con la propia escritura. Nada, y Benjamin lo sabe, podrá lograrse en las trincheras de la intelectualidad "si el escritor experimenta su solidaridad con el proletariado solamente en su mentalidad [nur seiner 
Gesinnung nach], y no en tanto ya que productor [nicht aber als Produzent]" (Benjamin, 2009b, p. 303; GS II 689).

El escritor como hombre de espiritu es, para él, parte de una casta que pretende definirse según sus opiniones, esto es, de manera no materialista, sin prestar atención al lugar real que ocupa en el proceso productivo en el que su trabajo se inserta. El autor deberá centrarse no ya en el producto, sino ahora en la acción misma de escribir entendida como producción, y mejorar el aparato con el que produce: tomar, en sentido fuerte, los medios de producción en lugar de limitarse simplemente a utilizarlos. Para Benjamin, debemos descentrar la atención de lo que el escritor dice - en la constelación de los temas, las opiniones, los debates, el contenido- y dirigirla al proceso real de producción de los textos.

La reflexión sobre la relación entre la forma y el contenido de la obra se anticipa algunos años antes en el "Prólogo epistemocrítico" que precede al libro sobre El origen del Trauerspiel alemán, por lo que, en función de esclarecer algunos conceptos, nos referiremos brevemente a este texto. Allí, Benjamin se refiere a la cuestión de la exposición, en tanto "es propio de la escritura filosófica [dem philosophischen Schrifttum] enfrentarse de nuevo, a cada viraje [mit jeder Wendung], con la cuestión de la exposición [der Frage der Darstellung]” (2006, p. 223; GS I 207) y la coloca como aquello que une a la filosofía con el arte. En ese contexto, plantea que "ha sido corriente colocar al filósofo demasiado cerca del investigador [Forscher], a menudo en la que es su versión más limitada. Ninguno parecía ser lugar, en la tarea [Aufgabe] propia del filósofo, para atender a la exposición” (Benjamin, 2006, p. 228; GS I 212).

En su obra, en cambio, el modo de exposición resulta central, en tanto su filosofía surge en la dialéctica entre forma y contenido, inseparables en sus textos, que se inscriben y no se inscriben, a la vez, en la filosofía y en el arte. Como apuntan Truskolaski y Sieber (2017), para Benjamin 
[1]a filosofía misma tiene tanto una dimensión científica como una dimensión estética. "El científico" y "el artista" no son meras metáforas, sino que representan los dos aspectos correlativos de "la tarea del filósofo": abordar el mundo empírico a la manera del científico y, al mismo tiempo, presentar el mundo de las ideas a la manera del artista. (p. 7)

El primer concepto que resulta relevante atender en el Prólogo del escrito sobre el Trauerspiel es justamente el de "exposición”. Lo que se persigue en filosofía es, argumenta el filósofo berlinés, la exposición de la verdad, que se distingue del conocimiento. En efecto, mientras que "el conocimiento es un haber [Erkenntnis ist ein Haben]" (Benjamin, 2006, p. 225; GS I 209), esto es, posee el "carácter de la posesión [Besitzcharakter]" (Benjamin, 2006, p. 226; GS I 209), la verdad no puede ser poseída, sino que es del orden de aquello que se manifiesta o se expone. Asimismo, y mientras que el conocimiento es intencional y opera con conceptos -es decir, mediante subsunciones y síntesis-, "la verdad es la muerte de la intención [die Wahrheit ist der Tod der Intention]" (Benjamin, 2006, p. 231; GS I 216) y se expresa en ideas, que "le están dadas a la observación" (Benjamin, 2006, p. 226). Aun así, cabe aclarar que Benjamin no rechaza de plano los conceptos, en tanto considera que pueden ser un medio para la exposición de las ideas. ${ }^{240}$

La filosofía, entonces, no tendrá tanto que ver con el conocimiento, en cuyo marco "se trata siempre de saber cuál es el camino correcto, el método, que le permite al sujeto apropiarse del objeto" (Gagnebin, 2005, p. 189), sino más bien con la verdad, cuyo método es el rodeo ${ }^{241}$. El ejercicio de la filosofía deberá consistir, entonces, para el Benjamin de 1928, en el abandono

\footnotetext{
${ }^{240}$ En palabras de Benjamin: "La diferenciación en conceptos queda a salvo de cualquier sospecha de puntillismo destructivo exclusivamente allí donde se haya propuesto ese rescate de los fenómenos en las ideas (...) Gracias a su papel de mediadores, los conceptos permiten a los fenómenos participar del ser de las ideas. Y justamente este papel de mediadores los hace aptos para aquella otra tarea, que resulta igualmente originaria, correspondiente a la filosofía, a saber, la exposición de las ideas" (2006, pp. 229-230). Sobre el concepto benjaminiano de idea remitimos a Holz (2014).

${ }^{241}$ Sobre esta máxima benjaminiana resulta muy interesante el artículo de Steiner (2002) “'Das Höchste wäre: zu begreifen, dass alles Faktische schon Theorie ist'. Walter Benjamin liest Goethe”. Allí, el autor trabaja con la máxima de Goethe en referencia a la cual titula el artículo y su recepción por parte de Benjamin.
} 
de dos actitudes que la signaron tradicionalmente. Como expone muy claramente Gagnebin, ello implica una doble renuncia:

al ideal del camino recto y directo en provecho de los desvíos, de la errancia; y renuncia también al curso ininterrumpido de la intención, esto es, renuncia a la obediencia a los mandamientos de la voluntad subjetiva del autor. ¿En provecho de qué? De un recomenzar y de un incesante volver a tomar aliento en torno a la Sache selbst, a la cosa misma (to on ontôs), centro ordenador y simultáneamente inaccesible del pensar y del decir. (2005, p. 188)

El énfasis en el modo de exposición recorre, como señala Steiner (2002, p. 276) la obra de Benjamin acompañando sus transformaciones. En los años 30, y especialmente en el marco del proyecto de los pasajes, esta inquietud se ligará al montaje y a la construcción, adquiriendo la forma de su conocida máxima metodológica: "Nada que decir, sólo mostrar" (Benjamin, 2013, p. 739).

La segunda aclaración conceptual que resulta relevante para nuestro análisis gira en torno al concepto de alegoría, y a su distinción con respecto al símbolo, de la que Benjamin se ocupa en la segunda parte del libro, en tanto es central para comprender la dialéctica entre forma y contenido tal y como él la presenta.

Y es que en la forma alegórica, que es la forma de expresión del Trauerspiel, se revela lo histórico y lo material (Lindner, 2014, p. 24), pero no como un mero contenido que es representado $o^{242}$ a través de esa forma pero podría serlo mediante cualquier otra ${ }^{243}$. La alegoría

\footnotetext{
${ }^{242}$ Sobre el concepto de representación, y el modo en que Benjamin se distancia de él, puede resultar esclarecedora la explicación de Jean-Marie Gagnebin, suscitada por una elección terminológica del traductor del texto al portugués. En el artículo "Do conceito de Darstellung em Walter Benjamin ou verdade e beleza" dice la autora: "[1]a palabra Darstellung -utilizada por Benjamin para caracterizar la escritura filosófica- no puede (...) ser traducida por "representación" (...), ni el verbo darstellen puede ser traducido por "representar". Aun cuando esa traducción pueda ser legítima en otro contexto, produce, en el texto en cuestión, un contrasentido, porque puede llevar a la conclusión de que Benjamin se inscribe en la línea de la filosofía de la representación, en el sentido clásico de representación mental de objetos exteriores al sujeto, de la que Benjamin toma distancia" (Gagnebin, 2005, p. 184. La traducción es nuestra).

${ }^{243}$ Los ecos de la teoría del lenguaje que Benjamin desarrolla en sus escritos juveniles se dejan oír aquí muy claramente. En "Sobre el lenguaje en cuanto tal y sobre el lenguaje del hombre", redactado en 1916, distingue
} 
no es "una mera sobrecodificación que realzaría la profundidad (y autoridad) del misterio: la alegoría es el trabajo desde la superficie misma de los fragmentos" (García, 2010, p. 171). Continuando con la interpretación de García, que compartimos:

Toda la crítica benjaminiana al concepto tradicional (clásico-romántico) de alegoría insistía en que ella no es una mera imagen ilustrativa que recubriría, como un velo, una abstracción conceptual, un precepto moral, un contenido previo y meramente recubierto por la imagen, pero enunciable de manera transparente (simbólica). La alegoría no se juega en la dialéctica entre velo (imagen) y profundidad interpretativa (precepto moral), sino en la diseminación de fragmentos y el trabajo de desciframiento. (García, 2010, pp. 170-171)

La alegoría funciona, entonces, como una escritura, "o mejor: como una escritura que tiende a la imagen" (Lindner, 2014, p. 35) 244 $^{44}$ también "representa un tipo de experiencia, definida en términos de aprehensión del mundo como algo no permanente" (Cohen, 2009, p. 144) que en el caso del barroco expresa

la constitución sufriente de su propio tiempo, el desgarramiento de una naturaleza mortificada que vivencia el alejamiento de la divinidad, esto es, su propia orfandad como condición insuperable. Y es eso mismo lo que ellas expresan: la imposible clausura de una realidad desolada que significa siempre y solo su muerte. Por tanto, expresar no implica representar, reunificar o reconciliar sino hacer justicia al darse de un mundo quebrado. (Espinosa, 2017, p. 53)

\footnotetext{
entre la función representativa del lenguaje (en la que el lenguaje es instrumentalizado y utilizado para representar algo que le es externo y para comunicar, así, un contenido) y la expresiva, en la que este rol mediador desaparece y en la que en el lenguaje (y no ya mediante el lenguaje), y típicamente en el nombre, el ser espiritual de las cosas, que es a su vez lenguaje, se comunica. La concepción burguesa del lenguaje, que lo entiende como "un instrumento de comunicación del sujeto" (Abadi, 2015, p. 198), es rechazada en pos de una concepción que Benjamin no vacila en llamar mágica y que se nutre de elementos teológicos.

${ }^{244}$ Dimópulos (2017) se refiere, en este sentido, a la contraestética que inaugura Benjamin, y hace hincapié en el antecedente de Aby Warburg, quien también pone sus esfuerzos en derribar el muro que separa imagen y palabra.
} 
Mientras que el símbolo celebra típicamente la unión armoniosa entre significante y significado, la alegoría permite romper con esa ilusión de armonía y de totalidad, en tanto

[c]uando el equilibrio entre significante y significado, núcleo del símbolo, es roto por una violencia que desaloja el sentido del mundo, los significantes cobran una materialidad en bruto que los reconduce a la ostensión de lo elemental de su materia sensible. En el grito de la inmanencia desnuda, phoné se desconecta de logos; sólo queda el chillido amorfo. Así sucede en la alegoría, y cuando la palabra se vacía resta el trozo amorfo, quedan los "áridos rebus" como modelo de una escritura (...) que, como pictograma, requiere ser leída. (García, 2010, p. 168)

Benjamin rechaza la filosofía del arte de su época (Steiner, 2002) -rasgo que comparte, como vimos, con Heidegger- en tanto interpreta la manifestación de la idea siempre como símbolo, relegando la expresión alegórica a un segundo plano. En la segunda parte de su trabajo sobre el Trauerspiel critica esta ideología de lo simbólico; ideología que incluye a su vez una distinción antagónica entre símbolo y alegoría -“el discurso moderno e insostenible de la alegoría y el símbolo [die moderne und unhaltbare Rede von Allegorie und Symbol] (Benjamin, 2006, p. 378)- con la incomprensión de este último y el rechazo de la primera (Benjamin, 2006, p. 378).

Esta simplificación, y la incomprensión a la que lleva, afectan al modo en que la relación entre forma y contenido de una obra es comprendida. En palabras de Benjamin:

a falta de un auténtico temple dialéctico, en el análisis formal se pierde el contenido, y en la estética del contenido [Inhaltsästhetik] se pierde la forma. Pues este abuso, en efecto, tiene siempre lugar cuando en la obra artística se expresa la "manifestación" de una "idea" en cuanto "símbolo" [wo im Kunstwerk die "Erscheinung" einer "Idee" als "Symbol" angesprochen wird]. (Benjamin, 2006, p. 376; GS I 336) 
En contra de esta tradición, Benjamin buscará rescatar la alegoría (así como busca salvar al barroco mismo), reinterpretándola. Pues "la alegoría (...) no es una técnica lúdica de producción de imágenes [spielerische Bildertechnik], sino que es expresión [Ausdruck], tal como es sin duda expresión el lenguaje, y también la escritura" (Benjamin, 2006, p. 379; GS I 339).

Aun cuando las ideas del libro sobre el Trauerspiel raramente son leídas en consonancia con los postulados, más cercanos al marxismo, que Benjamin presenta en "El autor como productor", hay importantes puntos de contacto. En ambos casos la relación entre la forma y el contenido de la obra es repensada, y el aislamiento de ambas esferas de análisis en términos dicotómicos es fuertemente cuestionado.

En el texto más temprano este tópico es trabajado en función de operar un rescate de la alegoría como forma de expresión del Trauerspiel y como única forma capaz de exponer aquello que el Trauerspiel busca mostrar. A su vez, la forma de exposición, desde siempre más y mejor atendida en el arte, es presentada como problema filosófico y atendida en tanto problema epistemológico. En "El autor como productor", un Benjamin ya cercano al materialismo histórico revisita estos tópicos en tanto le permiten cuestionar un tipo de compromiso político que se centra de modo exclusivo en el contenido de la obra, cuando no en formas que recuerdan a la alegoría en su comprensión más limitada, esto es, aquella que artificialmente esconde su mensaje tras un velo con una intención meramente didáctica.

En este contexto, el rebasamiento de los límites disciplinares impuestos a la actividad intelectual que propone Benjamin en el texto de su conferencia de 1934 puede ser leído como recuperando su preocupación por la cuestión de la exposición, que la filosofía ha descuidado, pero con la que se topa a cada giro y que debe ser repensada. En efecto, una de las maneras de transformar los aparatos de producción sería, para Benjamin, la experimentación técnica con los géneros literarios, como expresa a raíz de su crítica a la fotografía de la Nueva Objetividad: 
Tenemos pues un drástico ejemplo sobre qué significa abastecer un aparato de producción sin querer transformarlo [einen Produktionsapparat beliefern, ohne ihn $z u$ verändern]. Transformarlo habría significado derribar de nuevo una de esas barreras, superar una de esas contraposiciones que encadenan la producción de inteligencia. En este caso se trata de la barrera existente entre escritura e imagen [die Schranke zwischen Schrift und Bild]. ${ }^{245}$ (2009b, p. 307; GS II 693)

Este punto resulta central, en tanto da cuenta teóricamente de un ejercicio de producción que Benjamin había llevado a cabo algunos años antes en Calle de mano única, donde publica breves instantáneas filosóficas que tienen la particularidad de presentarse como imágenes de pensamiento. Aun cuando a primera vista no es más que un ejercicio de experimentación vanguardista, resulta importante recuperar este libro como una apuesta por presentar ideas filosóficas en un lenguaje que se acerca a la imagen, atendiendo a la exposición de modo tal que la verdad pueda al menos relampaguear ${ }^{246}$.

Asimismo, el llamado benjaminiano a repensar o redefinir el límite entre escritura e imagen tiene interesantes puntos de contacto con el desarrollo del arte en el siglo XX, y aun con derivas de la producción artística que él no pudo conocer. El caso de Kosuth y, en general, del arte conceptual, de su alejamiento del modelo de la representación y de su acercamiento al trabajo con las palabras, resulta especialmente relevante $-\mathrm{y}$ lo abordaremos, por consiguiente, en el próximo apartado--

\footnotetext{
${ }^{245}$ Si bien en esta investigación nos centramos sólo en algunos matices y sentidos del motivo de la imagen en Benjamin, en función de llamar la atención sobre el cruce entre los lenguajes del arte y la filosofía que se pone en juego en el siglo XX, el tema es inagotable y ha sido exhaustivamente estudiado. En especial, recomendamos para este tema la lectura de Weigel (1999), Zumbusch (2004), y, sobre el concepto -clave en la obra de Benjamin- de imagen dialéctica, Hillach (2014). García, por su parte, supo destacar que “'Actualidad' siempre se ligó en Benjamin a su teoría de la imagen como imagen dialéctica, es decir, no como mera apariencia estética sino como condensación política de la historia en un ahora crítico, como politización del tiempo en tanto realización de las virtualidades latentes en un pasado aún incumplido" (2013, p. 2).

${ }^{246}$ Calle de mano única, publicado el mismo año que el libro sobre el Trauerspiel, y si bien a simple vista puede no parecerlo, comparte con el texto de la frustrada habilitación de Benjamin algunos rasgos importantes, como ya notara Kracauer (1999).
} 
Volvamos entonces a Calle de mano única. Allí, Benjamin experimenta con algunas de las propuestas que, como vimos, sistematizará luego en "El autor como productor", y activa, asimismo, algunas de las ideas que presenta en el libro sobre el Trauerspiel tras su necesaria modificación al calor de su despertar materialista ${ }^{247}$. De contenido vanguardista, el libro reúne textos breves de formato variado que, desde el humor, el análisis político, la descripción o la ironía abordan temas que, en muchos casos, quedan fuera de los análisis filosóficos tradicionales.

Sigfried Kracauer, en su reseña conjunta de este libro y El origen del Trauerspiel alemán, dice que Benjamin, con su escritura, disocia las unidades experienciadas inmediatamente generando detonaciones (Kracauer, 1999, p. 263). Sin hablar de montaje, el teórico del cine parece estar pensando en él, ya que la potencialidad del cine, y más allá de él, de todo discurso que quiera dejar de imitar las narraciones y las ficciones que nos forman, radica justamente en esta disociación o en esta destrucción de las unidades tal y como se nos ofrecen.

En efecto, en sus notas para su análisis del cine de Chaplin, que recupera Kraniauskas a través de Buck-Morss, dice Benjamin que "lo que hay de nuevo en los gestos de Chaplin" es que "despedazan a los movimientos de la expresión humana en una serie de las más pequeñas inervaciones" (citado por Kraniauskas, 2012, p. 49). Estos movimientos, como aquellas unidades experienciadas inmediatamente, lejos de estar dados, están configuradas por los discursos en los que nos movemos cotidianamente, y de los que el cine y la prensa son sólo dos de los más relevantes.

\footnotetext{
${ }^{247}$ La relación entre alegoría y montaje resulta en este sentido central. Al respecto, ver García (2010) donde se explicitan las continuidades entre ambos conceptos (el trabajo con los fragmentos, el rechazo de la totalidad orgánica) sin desatender las diferencias, relacionadas en última instancia con algunos de los cambios que se introducen en la filosofía de Benjamin tras su acercamiento al marxismo. En un sentido similar Steiner (2002), al trabajar con la lectura benjaminiana de Goethe e incorporar para ello el artículo que Benjamin prepara sobre este autor para la Enciclopedia Soviética durante su estancia en Moscú, conecta de un modo muy esclarecedor algunos motivos anteriores a su encuentro con el marxismo y algunos posteriores, y de cuenta, como García, de algunas tensiones sin caer en la tentación de resolverlas.
} 
Volviendo a la reseña de Kracauer, allí el autor recupera muy apropiadamente, para caracterizar a Benjamin, la sugerente definición del filósofo como figura intermedia o habitante de dos mundos, esto es, el filósofo ocupando una posición intermedia entre el investigador y el artista (Kracauer, 1999, p. 264). Central para esta definición resulta, como mencionamos, la importancia brindada al modo de exposición, que en este caso arroja textos breves en los cuales, siguiendo a Kracauer, Benjamin expone la estructura discontinua del mundo, que experimenta cotidianamente frente al mito de la totalidad (que es expresado paradigmáticamente, en la filosofía, por el sistema).

A continuación, intentaremos caracterizar las breves "instantáneas filosóficas" (Richter, 2010, p. 252) con las que trabaja Benjamin, quien las llamó renuentemente, como menciona en una carta a su amigo Sholem, "aforismos" - se refiere al libro como “Aphorismenbuch") ${ }^{248}$-. Fue Adorno quien las bautizó "Denkbilder", “imágenes de pensamiento", usando, como apunta Leslie, una palabra que había sido introducida al alemán por Stefan George en una discusión sobre Mallarmé, para expresar "una representación concentrada de la experiencia, filtrada a través de imágenes, donde la presentación de los objetos era su propio comentario filosófico" (2007, p. 105).

Dos de sus rasgos principales son su alejamiento del concepto y su espacialidad. El primero nos enfrenta ya radicalmente con una ruptura con la forma en que tradicionalmente se presenta el discurso filosófico, esto es, en torno a argumentos, exposiciones por pasos y explicaciones. Las Denkbilder, en cambio, rehúsan estas formas de presentación trabajando con el rodeo del que hablaba Benjamin en el Prólogo de su estudio sobre el Trauerspiel, y acercándose asimismo a la narración ${ }^{249}$.

En “El arte de narrar” Benjamin observa que "ya no nos llega ningún acontecimiento que

\footnotetext{
${ }^{248}$ Cohen (2009) sostiene que "Benjamin también acude a Nietzsche para "arroparse" en esta nueva forma de hacer filosofía; sus aforismos, dirá nuestro autor, nada tienen de falta de rigor; muy por el contrario" (p. 143). ${ }^{249}$ Sobre el motivo de la narración, central en la obra de Benjamin, ver Oyarzún (2008), Gagnebin (1999) y Di Pego (2015).
} 
esté libre de datos explicativos" (Benjamin, 2011b, p. 163) y dice sobre la narración, oponiéndola fundamentalmente al discurso informativo de la prensa:

El mérito de la información pasa, en cuanto esta deja de ser novedad. Ella sólo vive en ese momento. Debe entregarse a él y explicarse sin perder tiempo. Pero con el relato sucede otra cosa: no se agota, sino que almacena la fuerza reunida en su interior y puede volver a desplegarla después de largo tiempo. (2011b, p. 163)

Resulta clave, en este punto, el caso de la historia del rey egipcio Samético, de Heródoto, que trae Benjamin a colación para ilustrar esta fuerza propia de la narración. De ella dice:

De lo que no cabe duda es de que todos los periodistas la explicarían en un abrir y cerrar de ojos. Heródoto no la explica ni con una palabra. Su relato es el más seco. Por eso esta historia del antiguo Egipto puede provocar asombro y reflexión aún hoy, después de milenios. (Benjamin, 2011b, p. 164)

En un sentido contrario al de la información periodística, que como vimos "permanece ajena a la experiencia del receptor, cuanto más se le impone en la forma de explicaciones respecto de la cosa" (Weber, 2014, p. 513), el arte, la narración y las imágenes de pensamiento con las que Benjamin puebla su filosofía no pueden ser meramente digeridas o asimiladas. Estas vías de exposición, lejos de ser meras formas que se le imprimen a un determinado contenido -como si hubiera un mensaje que puede ser transmitido en tanto narración, a través de una pintura o mediante una explicación-proponen una experiencia, en el contexto de aquella crisis de la experiencia que, como vimos, Benjamin diagnostica explícitamente en 1933 haciendo alusión a la imposibilidad de que las vivencias individuales sean elaboradas colectivamente por los sujetos, que ganan en información, pero pierden orientación en la vida. Proponemos pensar a las imágenes de pensamiento que Benjamin ofrece en Calle de 
mano única como tratando de proporcionar a los lectores una experiencia, al requerir de su parte un trabajo de elaboración del sentido, que no está dado ni simplemente oculto o velado. La filosofía no se da aquí como respuesta, y ni siquiera se da como pregunta: se presenta, a lo sumo, como una serie de preguntas a formular o de observaciones a realizar, en tanto, como observa César Rendueles, leer a Benjamin "hace saltar por los aires nuestra sensación de vivir una realidad completa y saturada, donde incluso los conflictos contribuyen mansamente a la buena marcha de la realidad constituida" (2013, p. 168).

Para lograr esto, se alejan no sólo del modelo expositivo-deductivo de la ciencia, sino también de la unidad más propia del pensamiento filosófico en su formato tradicional, a saber, el concepto. Sobre este punto coinciden no sólo los lectores actuales de Benjamin, sino también sus contemporáneos. Adorno, por ejemplo, sostuvo que

en contraste con todos los otros filósofos... el pensamiento de Benjamin, como paradójico que pueda sonar, no era uno que tuviera lugar en los conceptos... Él abría aquello que no podía ser abierto como si tuviera una llave mágica, y se situaba así, sin intención y sin especial énfasis, en irreconciliable oposición a la esencia clasificatoria, abstracta, integralmente grandiosa, de toda la Filosofía oficial. (Adorno, 2001, p. 29)

Esta llave, que le permite a Benjamin abrir aquello que en conceptos no se muestra, es justamente, creemos, su estilo, es decir, su atención a la exposición, tanto en la experimentación con los formatos de escritura como en su particular articulación del pensamiento en imágenes [Bilder], que lo acerca al lenguaje del arte.

Este alejamiento del concepto es muy significativo, no sólo por su carácter de gesto rupturista con respecto a la tradición filosófica (y a la concepción, tan arraigada, del conocimiento como un cierto haber), sino también -y este punto no recibió, creemos, la atención debida - en lo que respecta al movimiento que el arte realiza en el siglo $\mathrm{XX}$ de 
acercamiento al concepto y de alejamiento del soporte de la imagen. Volveremos sobre este punto en el próximo apartado.

El segundo rasgo que nos interesa destacar de las Denkbilder es la espacialidad que les es propia en su carácter de imágenes ${ }^{250}$. La presentación de razonamientos deductivos o la argumentación por pasos tiene, por su carácter progresivo, una cualidad temporal en la que los momentos se suceden unos a otros de modo lineal ${ }^{251}$, y el pensamiento del lector es guiado hacia conclusiones o asociaciones ya recorridas previamente por el autor. Benjamin evita este modelo: en "Sombras breves" 252 , de 1933, a su manera siempre críptica, lo deja claro: "lo decisivo no es la prosecución de conocimiento a conocimiento [der Fortgang von Erkenntnis zu Erkenntnis], sino el salto [Sprung] en cada uno de ellos" (Benjamin, 1989c, p. 150; GS IV 425). Las imágenes de pensamiento, al trabajar visualmente, son capaces de generar yuxtaposiciones en un montaje que evita la progresión ${ }^{253}$, y que se hace patente especialmente en la disposición espacial de los textos en el libro que nos ocupa, cuyas páginas fueron diseñadas emulando una calle. Como menciona Kraniauskas en su lectura, "lo que destaca por encima de todo es la organización simbólica del espacio: la topografía” (Kraniauskas, 2012, p. 32). Esta manera de presentar las ideas, si bien se presta, podría objetarse, a confusiones o

\footnotetext{
${ }^{250}$ Sobre este punto, Susan Sontag sostiene: "Los temas recurrentes de Benjamin son maneras de espacializar el mundo: por ejemplo, su noción de las ideas y las experiencias como ruinas. Comprender algo es comprender su topografía, saber cómo trazar su mapa. Y saber cómo perderse" (Sontag, 2007, p. 125).

${ }^{251}$ En este contexto es muy importante recordar la crítica a la ideología del progreso que llevará a cabo Benjamin en sus Tesis "Sobre el concepto de historia". En dicho texto y como expusimos en el capítulo 3, además de cuestionar la idea de progreso, Benjamin cuestiona la idea misma de historia del historicismo y su concepción del tiempo como homogéneo y vacío. Al respecto puede consultarse el estudio de Reyes Mate (2009). Asimismo, Naishtat (2008) ha destacado cómo Benjamin plantea en sus escritos sobre la historia "el problema del dispositivo de escritura y de la forma que es apta para condensar y optimizar la fuerza de una historiografía que pretende recrear el materialismo histórico y sustraerlo de la inercia aplanadora del marxismo vulgar y del historicismo" ( $\mathrm{p}$. 3).

${ }^{252}$ Benjamin publica en 1929 las primeras ocho entregas de sus "Sombras breves" en la Neue Schweizer Rundschau. Las restantes, entre las que se cuenta "Secreto signo", de donde citamos este fragmento, verán la luz en 1933 en Die Kölnische Zeitung.

${ }^{253}$ Esta forma de presentación de los textos, con la espacialidad que le es propia, encuentra ecos en varias ideas que Benjamin desarrolla en diferentes períodos. En torno al escrito sobre el Trauerspiel, por ejemplo, Benjamin se refiere al mosaico, en el que la individualidad de las piezas y la forma en que entran en relaciones entre sí son igualmente relevantes. Asimismo, y como ya mencionamos, el trabajo con el montaje y fundamentalmente con la idea de "mostrar" en lugar de "decir" es central en su Obra de los pasajes.
} 
malinterpretaciones, tiende, como la narración, a despertar en el lector un trabajo de elaboración que podría ser, justamente, la clave de salida de la crisis de la experiencia. La idea misma de malinterpretación, en tanto presupone un contenido fijo - a modo de mensaje- que el texto representa y que se esconde, velado, tras su forma críptica, va en contra del motivo de la exposición tal y como aparece en Benjamin, como mencionamos anteriormente en relación con la forma alegórica.

Hansen, por su parte, sostiene que Benjamin conceptualiza, a partir de su trabajo en Calle de mano única, formas de deshacer la alienación a través de la inervación o el inconsciente óptico y el juego (2012, p. 80). A su vez, la autora da cuenta de que el ensayo sobre la obra de arte también aspira a generar una experiencia desde el montaje, en tanto trabaja, en su forma de estructurarse mediante apartados, evitando un único punto de vista, un solo enfoque, una línea argumental continua sin fisuras ni saltos (2012, p. 89).

La imagen de los calcetines, con la que Benjamin trabaja en Infancia en Berlín hacia el 1900, es relevante para poner en evidencia la persistencia del motivo de la forma y el contenido en su obra:

El primer armario que se abrió cuando yo quería fue la cómoda. [...] Ahí me encontraba con mis calcetines, que descansaban amontonados y enrollados de modo que cada uno de los pares fingía ser una pequeña bolsa. Nada me causaba más placer que ir hundiendo mi mano en su interior [...]. Lo que me atraía hacia su hondura era lo que llamaba "el contenido", que mantenía dentro de mi mano en el interior siempre enrollado. Cuando lo agarraba con el puño para confirmar su posesión [...], comenzaba ya a desarrollar la segunda parte de aquel juego, que me conducía de inmediato a un descubrimiento emocionante. Ahora desplegaba "el contenido" desde el interior de aquella bolsa. Lo acercaba a mí cada vez más, hasta consumarse la sorpresa: "el contenido" salía de su bolsa, con lo que ambos dejaban de existir. No me cansaba de poner a prueba esa verdad enigmática: que forma y contenido, la envoltura y lo envuelto, son lo mismo. Lo son en la forma de una tercera cosa: el calcetín en que ambos se transforman. (2010d, pp. 226-227) 
Lo que Benjamin, educado en la escuela de Proust, señala por la vía de los objetos ${ }^{254}$ es que la forma y el contenido no pueden escindirse. El contenido, lo dicho, la verdad, se deshace en cuanto es retirado de la forma en que se encuentra alojado. Y no puede sorprender que Benjamin retome este episodio justamente en su texto sobre Proust. Allí sostiene:

Los niños conocen un signo en este mundo, a saber, el calcetín, que tiene justamente la estructura que corresponde al mundo de los sueños cuando, enrollado sobre sí en la cesta de la ropa sucia, es una bolsa y es su contenido. E igual que los niños no se cansan de transformar de golpe estas dos cosas (aquella bolsa y lo que hay en ella) aún en una tercera, que es el calcetín, Proust se mostró siempre inagotable en el vaciar de golpe al yo para introducir eso tercero, a saber, la imagen, que al fin calmara su curiosidad, aunque no, en absoluto, su nostalgia. (2007c, p. 320. Traducción levemente modificada)

Y es que la concepción proustiana del estilo, como afirma Melamed, "no se vincula con contenidos o temas, sino con las condiciones de posibilidad que nos proporcionan las obras de arte para aproximarnos a esos contenidos, temas, o en general a las cosas del mundo" (2006, p. 4). En consonancia con esta concepción, En busca del tiempo perdido no es un conjunto de ideas que podrían exponerse de otra manera, como si fueran un mero contenido que puede presentarse de formas diversas, sino un todo inseparable y complejo de aquello que se presenta al lector y el modo en que le es presentado. Este hecho, que para la reflexión sobre la literatura tiene carácter de obviedad, ha sido perdido de vista por la filosofía, que ha tendido a desestimar la forma de exposición como irrelevante, centrándose en el contenido de verdad en el que percibe que se hayan su potencia y su ser más propio. Quizá por eso, como recuerda Solas, en

\footnotetext{
${ }^{254}$ Richter (2015) ha llamado la atención sobre la obsesión de Benjamin con el mundo de los objetos (p. 35), que lo pone en la senda de Proust, pero también de Franz Kafka, Louis Aragon, Franz Hessel y Robert Walser. Asimismo, la atención a los objetos cotidianos de los que nos rodeamos y a su importancia en la configuración de nuestra experiencia pone a Benjamin en estrecha relación con Heidegger (p. 47).
} 
la disyuntiva de elegir como medio de expresión entre la literatura y el tratado filosófico, "Marcel Proust se inclina por el arte literario (...) puesto que tal diferencia radica más bien, en que el arte no es un medio para 'decir', sino para "poner de manifiesto"' (2006, p. 223). Benjamin repara en esta forma de Proust de poner de manifiesto, y en su texto sobre el autor francés escribe: "Nunca hasta entonces había habido nadie que nos mostrara las cosas como él; su dedo indicador no tiene igual [Nie gab es einen, der so wie er die Dinge uns zeigen konnte. Sein weisender Finger ist ohnegleichen]" (2007c, p. 328).

En este contexto, las obras de Benjamin, y especialmente las Denkbilder que componen Calle de mano única, en su intento por dar respuesta a la pregunta no siempre formulada por el cómo de la filosofía, son capaces de ofrecer un nuevo espacio de configuración del pensamiento y con él, un nuevo soporte para la reflexión. Así lo entiende también Weigel. En sus palabras:

En las imágenes de pensamiento resulta evidente que escritura y modos de pensar en Benjamin no pueden separarse, pero también que su manera de pensar en imágenes constituye no sólo la vía específica de su configuración teórica, sino también de su filosofía y de su escritura y, por último, que sus textos no pueden dividirse en forma y contenido. Mucho más puede extraerse todavía de las numerosas constelaciones de Leitmotive que forman sus textos, así como también puede descubrirse un modo particular de escribir logrado a partir de las tensiones entre la lengua poética y el metadiscurso conceptual, como si existiera un tercer elemento más allá de la oposición dualista entre literatura y filosofía. (Weigel, 1999, p. 103)

Y es que la potencialidad de la forma de escritura que caracteriza Calle de mano única, y con la que Benjamin buscaba que la literatura, en sus propias palabras, se acercara a formatos "que se corresponden mejor con su influencia en las comunidades activas que el pretencioso gesto universal del libro" (Benjamin, 2014, p. 43), lejos de modificar únicamente a la literatura, 
transforma también a la filosofía, que encuentra allí, citando la reseña de Adorno, el modo de "poner en movimiento al pensamiento que en su expresión tradicional y conceptual parece rígido, convencional y envejecido" (Adorno, 2001, p. 29). Y esta escritura, que quería salirse de los formatos clásicos y tener influencia en las comunidades activas, fue puesta a circular en 1994 por las calles de Berlín por un artista conceptual: Joseph Kosuth, un artista cuya obra se caracteriza por su estrecha relación con la reflexión filosófica. A continuación, nos centraremos en este autor y en el modo en que puede encontrarse con Benjamin en el espacio que ambos exploran entre el arte y la filosofía.

\subsection{Joseph Kosuth o el artista como filósofo}

Los géneros brindan una expectativa afectiva respecto a cómo habrá de experimentarse el despliegue de algo, ya sea en el arte o en la vida. El ocaso de los géneros abarca distintos tipos de aperturas potenciales dentro y más allá del impasse de adaptación que crea la situación de crisis constante.

Lauren Berlant, 2020, pp. 27-28

En este apartado nos concentraremos en la obra de Joseph Kosuth desde dos perspectivas: por un lado, nos referiremos al marco teórico que el artista escribe para su obra; por el otro, exploraremos su obra Berliner Chronik, basada en la de Benjamin.

La obra de Kosuth se enmarca, como menciona Ana María Guasch (2001), dentro del arte conceptual, que, lejos de ser un estilo artístico definible, puede ser comprendido como un proceso histórico y artístico complejo que tiene, por un lado, antecedentes muy relevantes, como el arte minimal y el arte concepto, y, por el otro, consecuencias y prolongaciones muy significativas $^{255}$. En efecto, el arte conceptual da lugar a otros movimientos y surgimientos,

\footnotetext{
${ }^{255}$ Sobre el arte de concepto puede consultarse Marchán Fiz (1994). Allí, el autor habla de Kosuth como "la figura más definida del conceptualismo lingüístico" (p. 250).
} 
tanto en el ámbito de la producción artística como en el de la reflexión teórica sobre el arte, que se enmarcan en el contexto de una redefinición radical del campo artístico que se prolonga hasta nuestros días y que no parece tener fin. Un proceso que resulta central en este desarrollo, y en el que nos detendremos especialmente, es el de la desmaterialización del arte, cuyo comienzo podemos situar, siguiendo a Guasch (2001) y a Marchán Fiz (1994), en los primeros movimientos de oposición a la escuela formalista de Nueva York, y en el cual Kosuth, como artista y como teórico, no puede dejar de ser considerado. También para Benjamin Buchloh, el arte conceptual significa "la más rigurosa eliminación de la visualidad y de las definiciones tradicionales de la representación” (Buchloh, 1990, p. 107).

Kosuth participó, junto a otros artistas, en la primera exposición de arte conceptual, que tuvo lugar en la Dwan Gallery de Nueva York en junio de 1967, y que se llamó "Language to be looked at and/ or Thing to be read", y publicó su célebre ensayo "Art after Philosophy" en 1969. En la exposición, el artista presentó una serie de obras basadas en la relación entre los objetos materiales, las palabras que los nombran y las definiciones de estas palabras. Luego de esta primera exposición se sucedieron muchas otras, tanto grupales como individuales y, como es esperable, la obra de Kosuth, con eje en la redefinición constante de la naturaleza y la función del arte, siguió mudando de formato y de contenido, aun cuando mantuvo siempre un mismo ímpetu y una misma intención.

Donald Karshan, que escribió el catálogo de otra exposición en la que Kosuth participó (“Conceptual Art and Conceptual Aspects", de 1970) sostiene que "el arte del post-objeto está basado en la premisa de que la idea de arte se ha extendido más allá del objeto o de la experiencia visual al ámbito de la investigación” (citado por Guasch, 2001, p. 173). En efecto, el arte se separa de la tradicional experiencia estética y se aloja en la idea o en el concepto para hacer posibles experiencias de un tipo nuevo. 
En "Art after Philosophy”, su programático escrito de 1969, Kosuth sostiene que "hemos de juzgar a los artistas en función de su modo y capacidad de cuestionar la naturaleza del arte" (Kosuth, 1991, p. 18) y plantea, en este sentido y como luego hará Danto (2010), que habría un antes y un después de la obra de Marcel Duchamp.

El escrito de Kosuth presenta varias tesis fuertes, algunas de las cuales son desarrolladas y explicadas por el autor, mientras que otras resultan más crípticas. Este último es el caso, por ejemplo, de la idea del fin o la irrealidad de la filosofía, que Kosuth parece tomar del Tractatus logico-philosophicus de Ludwig Wittgenstein, publicado en 1923. Si bien Kosuth ofrece algunas razones para sostener la caída de la forma tradicional de filosofar -afirma que la filosofía dejó de ocuparse de lo no dicho; que ya no hay nada más que decir; que hay, a diferencia de otros momentos históricos, demasiada información-, no queda claro por qué cree que la filosofía que se produce en su tiempo no debería ser llamada filosofía. La tesis de que "el siglo veinte trae un tiempo que podría ser llamado 'el fin de la filosofía y el comienzo del arte"” (Kosuth, 1991, p. 14), o al menos su primera afirmación -acerca del fin de la filosofíano parece estar suficientemente justificada en el escrito, en tanto no se da una definición de filosofía que pueda ejercer de parámetro para determinar si una producción es o no filosófica. Por otro lado, mientras que sobre el arte sostiene, citando a Don Judd, que "si alguien lo llama arte, es arte" (Kosuth, 1991, p. 17), Kosuth no parece considerar lo mismo de la producción filosófica. Quizá el autor piense aquí como Danto, quien en su diagnóstico acerca del “fin del arte" aclara:

yo también pienso en el arte en sí mismo como algo que nombra no tanto una práctica como un movimiento, o incluso un período, con marcadas fronteras temporales. Esto es, por supuesto, un dilatado movimiento o período, aunque hay una buena cantidad de movimientos o prolongados períodos históricos tan universalmente incorporados en la actividad humana que a veces olvidamos pensarlos históricamente, y una vez que lo hacemos, podemos imaginar de un modo 
u otro su final -el de la ciencia y la filosofía, por ejemplo-. Éstos se podrían extinguir sin que se desprenda de ello que las personas dejen de filosofar o hacer ciencia. $(2010$, p. 47$)$

A partir de este diagnóstico de época, Kosuth se propone dos cosas: por un lado, analizar la función del arte y su viabilidad, y por el otro, ofrecer una explicación clara acerca de qué es el arte conceptual, en el que su producción se enmarca. Para ambos puntos será decisiva la diferencia que plantea entre arte y estética. Esta última "lidia con opiniones sobre la percepción del mundo en general" (Kosuth, 1991, p. 16), en la constelación del "gusto", y así, no se limita a los objetos considerados artísticos, sino que emite juicios que los exceden, en tanto dichos juicios no toman en consideración la función del objeto sino sólo sus atributos físicos. El arte, en cambio, tiene que ver justamente con la función, y por eso comienza -en la opinión de Kosuth- con aquel episodio a partir del cual la pregunta acerca de la función del arte fue planteada: la presentación de los Ready-mades de Duchamp (Marchán Fiz, 1994, p. 250).

Aquello que hace a la obra de Duchamp tan relevante a los ojos del artista conceptual es el hecho de que, antes de él, "el lenguaje del arte permanecía inalterado, pero estaba diciendo cosas nuevas" (Kosuth, 1991, p. 18), mientras que, después de él, el arte se centra en trabajar sobre su propio lenguaje, dándose lenguajes nuevos, tras descubrir que "era posible hablar otro lenguaje y aun así hacer algo que tuviera sentido" (Kosuth, 1991, p. 18) en el campo del arte. Las nuevas producciones y los nuevos artistas, a partir de este cambio de paradigma, serán juzgados según cuán radicalmente sepan cuestionar la naturaleza del arte, lo que implica que su apreciación será conceptual y no ya estética. Este punto de la reflexión de Kosuth lo explica muy bien Genette, quien sostiene que las obras ya eran conceptuales antes de que el arte conceptual, así considerado, entrara en escena. Para él, hay una recepción conceptual y una recepción estética del arte, que exceden por mucho al arte conceptual, si bien éste ha sabido trabajar muy lúcidamente sobre esta distinción, y crear obras "cuyo objeto de inmanencia es 
(...) un concepto (...) y cuya manifestación puede ser ora una definición ora una ejecución" (Genette, 1997, p. 166).

En la ampliación que realiza Genette del campo de aplicación del mote de "conceptual" para el arte, lo que hace conceptual a una obra es que el objeto es presentado

no en virtud de sus cualidades estéticas en el sentido corriente, sino, al contrario, en virtud del carácter crítico, paradójico, provocativo, polémico, sarcástico o simplemente humorístico que acompaña al acto de proponer como obra de arte un objeto o un acontecimiento cuyas propiedades suelen considerarse no artísticas o antiartísticas. (Genette, 1997, p. 168)

Con esta definición ampliada de lo conceptual, todas las obras que hayan tenido una "recepción conceptual por parte del público, al que sorprendían por sus normas o hábitos" (Genette, 1997, p. 170), esto es, todas las obras que han propuesto un cambio de paradigma en el arte, pueden ser consideradas conceptuales. A diferencia de Kosuth, que parece colocar lo conceptual del lado del autor -en la propuesta que éste hace de que lo que presenta sea considerado arte-, Genette piensa en la recepción de la obra como una instancia que la constituye en su carácter mismo de conceptual, en tanto el funcionamiento conceptual de una obra, como él lo llama, es siempre en parte independiente de la intención del artista.

Pese a esta diferencia, creemos que la explicación de Genette acerca de las operaciones de reducción que tienen lugar en el arte conceptual resulta esclarecedora también para comprender la perspectiva de Kosuth y su obra. Dichas reducciones son, en primer lugar, la que se opera al presentar el objeto que se tiene enfrente como una obra de arte y, en segundo lugar, la que tiene lugar desde dicho acto al concepto como el objeto ideal que le da sentido a la obra. Nuevamente, en Kosuth, estas dos reducciones parecen tener lugar en las intenciones del autor, mientras que para Genette se configuran en la recepción de la obra. Para este último, “siempre es más o menos lícito recibir una obra ora en modo 'perceptivo’ (...) ora en modo 
conceptual -remontándose del objeto al acto y del acto al concepto-, ora según alguna combinación de las dos actitudes de recepción” (Genette, 1997, p. 176).

Volviendo entonces a la argumentación de Kosuth, un punto muy importante que presenta en este artículo es la caracterización de la obra de arte como una proposición analítica, en el sentido kantiano o, más bien, siguiendo la interpretación que Alfred Jules Ayer hace de la tesis kantiana. Enmarcándose en el universo terminológico kantiano, pero yendo también mucho más allá de él, afirma Kosuth que el arte - entendido como una proposición- no está afirmando nada acerca del mundo, y que por ello no tiene sentido que su contenido de verdad sea contrastado con los hechos empíricos. Cuando un artista presenta una obra, la proposición que está defendiendo es siempre "esto es arte", es decir, está proponiendo -desde la acciónuna cierta definición de arte. Esta definición, esto es, la propuesta de que eso que se está presentando - una obra, una idea, un hecho, un objeto- es arte, no es verificable empíricamente, y ahí radica su carácter de juicio analítico.

Conviene que nos detengamos brevemente en este punto, en tanto pone de manifiesto una tensión crucial con la filosofía tal y como la comprendió Benjamin. Como ella, el arte renuncia a la representación del mundo, pero, a diferencia de ella, renuncia también a la exposición de toda verdad que no se refiera a sí mismo. Siguiendo la argumentación de Kosuth, el arte no tendría ningún objeto más que sí mismo, mientras que la filosofía mantendría, aun a fuerza de modificarla muy marcadamente, una relación con el mundo, aunque no ya mediante su comprensión como un objeto sino, con Benjamin, en términos de una cierta tarea que es enunciada de formas diversas, ya como salvación de los fenómenos, ya como una "mostración" por medio del montaje.

La argumentación de Kosuth prosigue hacia una comprensión de la obra de arte como algo más relacionado con la función que con la apariencia o la forma. Si bien qué función proclama para el arte en la sociedad es algo que no se desprende de modo transparente del 
texto, hay algunas indicaciones que pueden ayudarnos a vislumbrar el rol que el arte podría cumplir: por un lado, Kosuth sostiene que la capacidad del arte para existir dependerá de que se abstenga de ofrecer un servicio -por ejemplo, decorar o entretener-. Por otro lado, el arte deberá mantenerse alejado de los juicios filosóficos o, más específicamente, de comprometerse con una postura filosófica. Al mantenerse entonces al margen de funciones y posturas fijas, el arte será para Kosuth capaz de cumplir con una tarea que les estaba asignada otrora a la religión y a la filosofía, a saber, "satisfacer aquello que en otra época podría haber llamado 'las necesidades espirituales del hombre"” (Kosuth, 1991, p. 24) en tanto el arte "lidia con el estado de cosas que están más allá de lo físico" (Kosuth, 1991, p. 24).

Sobre este punto, ligado a la función del arte, nos interesa hacer dos observaciones. En primer lugar, que al colocar al arte en una línea de continuidad con la religión y con la filosofía comprendida como metafísica, Kosuth corre el riesgo de acercarse a aquello que Benjamin llamará “teología del arte”, al mantener al arte en una esfera de pureza religiosa, y al asignarle una función casi mítica. En este sentido, las afirmaciones de Genette nos parecen alojar una potencialidad mayor para comprender la función o las funciones posibles para el arte en nuestra época. Este autor pone el énfasis, hablando del gesto propio del arte conceptual, en que "el significado y la función de dicho gesto sigue siendo, por su parte, indefinido, abierto y suspendido como el de cualquier objeto estético (...). No sabemos exactamente qué quiso decir Duchamp" (Genette, 1997, p. 177). Como veremos en el próximo apartado, esta indefinición, esta falta de explicación o explicitación, es justamente, para Benjamin, especialmente en su análisis de la narración, el sitio donde se aloja la potencialidad de la obra, que se desplegará o no- cuando encuentre un receptor que realice un trabajo activo de desciframiento ${ }^{256}$. Genette parece dejar, tanto en la definición de qué sea el arte conceptual como con respecto a la función

\footnotetext{
${ }^{256}$ De la misma manera y como atendimos en el capítulo 3, en el pasado también late, para Benjamin, una misma potencia, que se despliega en la medida en que un presente haga una experiencia con ese pasado.
} 
del arte, más lugar para el receptor que Kosuth, para quien el artista tiene aún una centralidad considerable.

Asimismo, y después de afirmaciones de corte más rupturista, ligadas a la filosofía contemporánea y marcadamente en contra de posturas nostálgicas acerca de algo así como "lo clásico", Kosuth parece recaer en algunos lugares comunes acerca de la función del arte, y con él de la filosofía y de la religión. La idea misma de unas "necesidades espirituales" y de aquello que "está más allá de lo físico" resultan al menos sorprendentes en pleno siglo XX. El diagnóstico acerca del fin de la filosofía, que el autor postula al comienzo del texto y que no queda del todo claro, en este escenario, se esclarece: si la filosofía es la filosofía de esa tradición, o más directamente, si la filosofía se identifica con la metafísica y con sistemas cerrados, entonces sí hay razones para proclamar su muerte (o su agonía) en el siglo XX. No obstante, la filosofía muta a lo largo de este siglo no sólo hacia un análisis del lenguaje, sino también -tanto en Europa como en Estados Unidos y en Latinoamérica- hacia un análisis político y social orientado hacia múltiples áreas, fenómenos y conflictos, entre los cuales los feminismos, las diferentes filosofías de la educación, los análisis sobre el arte o filosofías como la existencialista o la pragmatista son sólo algunos ejemplos. Kosuth, si bien parte de Wittgenstein y trabaja, posteriormente, con textos de Benjamin, no parece tener en cuenta, a la hora de argumentar, todo aquello que atraviesa a la filosofía una vez que esta abandona sus pretensiones clásicas y que la reconfigura radicalmente: quizá, como veremos más adelante, esta reestructuración sea tan radical como la que significa para el arte la irrupción del arte conceptual, que el mismo Kosuth reconoce y celebra. Aun así, y si bien no nos centraremos en este aspecto de su pensamiento, tan alejado como estuvo siempre de aquellos que no llamarían arte al arte contemporáneo, Kosuth parece haberse alineado con aquellos que no llamarían filosofía a algunos de los desarrollos filosóficos del siglo XX. 
La exposición de Kosuth en la que Benjamin fue protagonista se llamó Berliner Chronik. Si bien, al tratarse de una instalación efímera, no es posible reconstruirla en su totalidad $^{257}$, tenemos noticia de algunas de las acciones que involucró, a partir de las notas publicadas en el periódico alemán de tirada diaria Die Tageszeitung (taz) -que participó en la organización de la instalación-. A partir del 7 de julio de 1994, Kosuth citó fragmentos de obras de Benjamin en las páginas de este mismo diario durante siete días, así como intervino también otras áreas de la comunicación -televisión, cine, teatro, arquitectura, arte e internet ${ }^{258}$ con pasajes de la obra del filósofo: en el canal de televisión B1 fueron vistas citas de Benjamin durante diez días; hasta el 31 de julio fue proyectado un tráiler (cuyo contenido hoy se desconoce) en nueve cines de Berlín; por cuatro días una inscripción permaneció instalada en una obra en construcción en el centro de la ciudad.

Berliner Chronik es, asimismo, el título de un texto de Benjamin de 1932, y el hecho de que Kosuth titule así su obra no deja de resultar significativo. Y es que la Crónica de Berlín de Benjamin es una exploración de la propia memoria y de la forma en que esta trabaja espacialmente, atendiendo a imágenes, lugares y ruinas más que a continuidades, hitos y líneas temporales. Benjamin mismo da cuenta del tipo de ejercicio al que se entrega en este texto distanciándolo de la autobiografía, en tanto la misma "se da siempre en relación al tiempo, a su decurso y, finalmente, lo que constituye el fluir continuo de la vida. Pero aquí se trata de un espacio, sólo de instantes, de lo discontinuo" (Benjamin, 2017c, p. 647).

El carácter topográfico de los recuerdos que tejen el relato, junto a la forma en que la ciudad emerge menos como paisaje o escenografía que como personaje, hacen que edificios,

\footnotetext{
${ }^{257}$ Nos hemos puesto en contacto con Kunst-werke, el Instituto de Arte Contemporáneo que junto con Kosuth organizó la instalación, cuya colaboración en esta investigación agradecemos, y aun así no fue posible encontrar más información sobre qué otras frases de Benjamin fueron mostradas en los diferentes medios. El libro que acompañó la exposición (Klaus Biesenbach y Harald Fricke (Ed.): Joseph Kosuth. Berlin Chronicle - A Temporary Media Monument for Walter Benjamin. Berlin: KW Institute for Contemporary Art, 1994) es asimismo casi imposible de conseguir.

${ }^{258}$ Según una nota publicada en taz el 4 de julio de 1994 y disponible en la página web del diario.
} 
obras en construcción y periódicos resulten medios más que apropiados para situar la escritura de Benjamin, que se origina, en alguna medida, en la experiencia de habitar la ciudad. Consciente de la importancia de los lugares, y típicamente de las ciudades, en su vida, Benjamin jugaba con la idea de "articular gráficamente en un mapa el espacio de la vida" (Benjamin, 2017c, p. 621), como si la misma se desplegara más en las superficies habitadas que en el continuo temporal. La presencia de Proust, a quien Benjamin se refiere en este texto como uno de sus guías (Benjamin, 2017c, pp. 622-623), es innegable, tanto en la atención a los lugares como en la relación entre la memoria y la imagen y en la destrucción de la idea de tiempo lineal que opera a la base de la ideología del progreso. El trabajo con la imagen, al que nos referimos anteriormente, y el mostrar o exponer en lugar de brindar explicaciones o representar cadenas deductivas encuentra en este guía - de quien el berlinés fue también traductor- un antecedente importante. En palabras del mismo Benjamin: "el procedimiento empleado por Proust ya no es el modelo de la reflexión, sino el hacer presente en cuanto tal" (Benjamin, 2007c, p. 327).

Berliner Chronik de Kosuth se presenta, en varios aspectos, como una materialización de las ideas -tanto de Benjamin como de Kosuth- que venimos explorando. Por un lado, y aunque posee un soporte físico y visual, no es posible hacer de esta instalación una experiencia estética tradicional, en la que se aprecian las características relativas al aspecto de la obra (o en palabras de Genette: la obra no invita a una recepción estética). La desmaterialización del arte, si bien no completamente, hace una cierta entrada aquí: al menos ni la imagen, en sentido tradicional, ni el objeto están presentes y, en su lugar, aparece el lenguaje. Sin embargo, desde la perspectiva de la filosofía este irrumpir en el espacio de la ciudad puede ser entendido, contrariamente, como una cierta materialización, a través de la cual los textos filosóficos pueden encontrar receptores antes impensados o situaciones de recepción diferentes de las que propone el formato tradicional del libro, especialmente dada la posibilidad de una recepción 
colectiva (en el caso de las inscripciones en edificios, en obras y en el cine o el teatro), y de una recepción en la dispersión.

La propuesta de Kosuth, en su carácter de obra conceptual, está diciendo, “esto es arte”, y eso que es arte no es otra cosa que filosofía. La tradición con la que se entabla una relación en este caso no es la historia del arte sino la del pensamiento filosófico. Aun así, en su homenaje al "Berlín vivido" (Benjamin, 2017c, p. 622) de Benjamin, Kosuth elige una frase que se refiere, ahora sí, al arte y a su lugar en la sociedad. Así, en el frente del edificio de KunstWerke, el Instituto de Arte Contemporáneo junto al cual organizó la intervención, el artista coloca una cita de "El autor como productor", que permanece allí hasta la actualidad y que reza:

Man kann erklären: ein Werk, das die richtige Tendenz aufweist, braucht keine weitere Qualität aufzuweisen. Man kann auch dekretieren: ein Werk, das die richtige Tendenz aufweist, muss notwendig jede sonstige Qualität aufweisen [Se puede explicar: una obra con la tendencia correcta no necesita de otra calidad. Y también puede decretarse que una obra con la tendencia correcta ha de tener necesariamente todas las restantes calidades]. (Benjamin, 2009b, p. 298; GS II 684. Traducción levemente modificada)

Esta afirmación de Benjamin se refiere, como ya comentamos, a sus reflexiones sobre el lugar del arte en la sociedad y específicamente sobre su posibilidad de incidir en lo social de una manera políticamente justa. En dicho marco, Benjamin concluye que el autor, entendido como productor, debe centrarse en modificar su mismo proceso productivo, e indica varias tareas que Kosuth parece tomarse en serio aquí: descreer de la dicotomía estéril que se tensa entre la imagen y el lenguaje, modificar los medios de producción en lugar de limitarse a alimentarlos, cambiar la relación con los posibles receptores de la obra, y repensar el modo en que forma y contenido, o tendencia política y calidad, se relacionan en una obra. 
Asimismo, Kosuth parece llevar más allá, en su obra homenaje, la tendencia que encuentra Benjamin en su época respecto de la escritura en Calle de mano única. Dos fragmentos de este libro resultan muy claros en este sentido. El primero sostiene que "la eficacia literaria trascendente (...) debe cultivar los discretos formatos del volante, el folleto, el artículo de revista y el cartel publicitario" (Benjamin, 2014, p. 43). Benjamin le pide a la literatura que se mude a formatos más propios de la época contemporánea, y en este caso quien le responde es un artista conceptual, llevando sus textos a la fachada de un edificio, a un periódico o a la televisión en una operación caracterizada por la cita. El segundo fragmento es el siguiente:

La escritura, que había encontrado asilo en el libro impreso, donde llevaba adelante una existencia autónoma [wo sie ihr autonomes Dasein führte], es sacada a la calle y sometida a las brutales heteronomías del caos económico. Esa es la severa escolarización de su nueva forma. Si hace siglos empezó paulatinamente a inclinarse, pasando de la inscripción vertical a la oblicua letra a mano que reposa sobre atriles, para por último recostarse en la letra impresa, empieza ahora con la misma lentitud a levantarse otra vez del piso [beginnt sie nun ebenso langsam sich wieder vom Boden zu heben]. Ya el periódico se lee más en vertical que en horizontal, mientras que el cine y la publicidad empujan la letra hacia la verticalidad dictatorial [in die diktatorische Vertikale]. $\mathrm{Y}$ antes de que un contemporáneo llegue a abrir un libro ha caído sobre sus ojos un torbellino tan denso de letras de moldes versátiles, coloridas y contendientes, que las chances de penetrar en la arcaica tranquilidad del libro han quedado disminuidas. Los enjambres de langostas escritas, que hoy ya les ensombrecen a los habitantes de las metrópolis el sol del supuesto espíritu [die heute schon die Sonne des vermeinten Geistes den Großstädtern verfinstern], se harán más densos con cada año venidero. (Benjamin, 2014, p. 66; GS IV 103)

En este segundo texto, Benjamin narra la historia de la escritura, que va mudándose de formatos y que estaría, en el siglo XX, volviendo al soporte vertical que le diera asilo antes de 
la invención del libro como objeto. La escritura "es sacada a la calle", dice Benjamin, refiriéndose a los carteles publicitarios que configuran el paisaje citadino. La relación entre la escritura y la ciudad, presente aquí, se complejiza justo en la encrucijada (o en la esquina) entre Benjamin y Kosuth: la ciudad, que en Calle de mano única, como se expuso, hace su aparición y puebla el libro, dotándolo no sólo de una calle sino también de un montaje de edificios, pasajes y mensajes que emulan la forma de recepción propia de la experiencia urbana, esa ciudad, entonces, se ve en el caso de Kosuth intervenida por el lenguaje: es el libro el que le presta ahora a la ciudad su propio rostro.

En el gesto artístico de Kosuth, en este sacar la escritura a la calle, textos de Benjamin aparecen en los años noventa en las calles de la gran metrópoli que es Berlín, lo que genera al menos dos rupturas. Por un lado, textos no publicitarios le hablan al habitante de la ciudad sin un objetivo comercial, informativo ni ideológico a la vista, y sin siquiera parecer tener un objetivo específico. En este sentido, la lógica de la publicidad es subvertida, y una intervención artística irrumpe el espacio público sin una agenda clara. Pero el tipo de texto, su contenido temático o su intención no son lo único que aparta este gesto artístico de la publicidad: además de filosóficos, los textos son inactuales. A diferencia de los carteles publicitarios, y de la información, que cambian rápidamente y buscan una efectividad inmediata, las frases de Benjamin -60 años después de su momento original de enunciación- significan en algún sentido una cierta experiencia con el pasado en la que este emerge sin avisar, lejos de soportes que lo conviertan en una mera pieza de museo.

Asimismo, la elección de la cita de "El autor como productor" parece materializar las ideas de Kosuth que analizamos en su escrito: el arte conceptual se refiere a sí mismo, y habla en este caso a través de Benjamin de su propia relación con la realidad social. Su proposición dice algo acerca del arte, porque en su etapa conceptual el arte se convierte en tema para sí mismo. Sin embargo, la elección del texto que Benjamin redacta con el fin de poner en cuestión 
el lugar de los intelectuales y artistas y de pensar de qué manera pueden, el arte o la filosofía, incidir de una manera justa en el ambiente público, da cuenta de la intención de Kosuth de posibilitar una cierta experiencia política, experiencia que le propone al paseante el arte, después de la filosofía.

Otra de las citas que eligió Kosuth, y que apareció en el diario Die Tageszeitung, está extraída de "Sobre algunos motivos en Baudelaire". Benjamin se refiere allí a la forma de circulación de la información, tal y como se da en los periódicos, y a la que distingue, como mencionamos, de la narración oral que la precedió, poniendo a jugar dos de los motivos centrales de su pensamiento a los que nos referimos en los capítulos 4 y 5 de esta investigación, a saber, la narración y la experiencia. El fragmento es el siguiente: “Alle diese Formen heben sich ihrerseits von der Erzählung ab; sie ist eine der ältesten Formen der Mitteilung [Todas esas formas se apartan igualmente por su parte de la narración, que es una de las formas más antiguas de comunicación que se conoce]" (Benjamin, 2008c, p. 212).

Conviene reponer algo del contexto: inmediatamente antes de la frase citada dice Benjamin en su escrito sobre Baudelaire: "En la sustitución de la antigua relación por la ya moderna información, y de la información por la sensación, se refleja la atrofia creciente y actual de la experiencia” (Benjamin, 2008c, p. 212).

En el mismo sentido, y sólo unas líneas después de la citada frase, dice Benjamin:

La obra en ocho volúmenes de Proust nos da idea de qué disposiciones eran precisas para restaurar en el presente la desgastada figura del narrador. Proust la emprendió con magnífica coherencia, y así, desde el comienzo, acometió una tarea elemental: componer un relato de la propia infancia. (Benjamin, 2008c, p. 212)

Kosuth explora, con toda su producción, pero específicamente con la instalación que analizamos aquí, las posibilidades del arte de interpelar en el contexto de la atrofia de la experiencia y de las modificaciones que la técnica y la vida en las ciudades imponen a prácticas 
que tradicionalmente eran constitutivas de la vida en comunidad. Como Benjamin, y con Benjamin, el artista conceptual se propone posibilitar una experiencia en la era de su crisis, pero la experiencia posible será, lejos de toda nostalgia por formas de vida pasadas, fragmentaria.

No en vano, repetimos, nombra Kosuth a su homenaje "Berliner Chronik", en clara referencia a la obra en la que Benjamin, siguiendo las huellas de Proust, se propone componer su propia infancia desatendiendo cronologías y teleologías que falsean el recuerdo, lejos de toda estetización de la propia historia, a través de la fragmentación y el montaje que le son propios a la memoria ${ }^{259}$.

\subsection{Entre la imagen y el concepto}

Además de conceptos y saberes, la filosofia lega imágenes.

Mariana Dimópulos, 2017, p. 11

Entre las obras de estos dos autores es posible generar un cierto campo de tensión en el que se inscriben interesantes puntos de contacto y algunos cruces llamativos que resultan productivos para pensar la relación de Benjamin con los formatos y lugares posibles para el trabajo intelectual. Ambos han intentado, desde sus ideas y desde su obra, traspasar los límites que los campos estancos imponían a su producción con el objetivo de ofrecer un camino de renovación en sus áreas de desarrollo, y ambos lo han hecho menos por el simple placer de explorar que movidos por la conciencia de una ruptura con la tradición, y de vivir en un siglo que clama por nuevas formas de interpelar. Ambos han cuestionado, con su trabajo, la división

\footnotetext{
259 Lindroos (2001) ha argumentado que las reflexiones benjaminianas sobre las transformaciones de la experiencia y su relación con la narración, así como con las formas de escribir la historia, han inspirado el diagnóstico posmoderno del fin de las grandes metanarrativas (p. 22).
} 
tajante entre lenguaje e imagen bajo el régimen de la cual vivimos, y han logrado construir obras que operaron interesantes corrimientos de las fronteras de lo esperable en su sector productivo, poniendo en cuestión la naturaleza de su área propia de producción y lo hacen menos escribiendo teoría del arte o metafilosofía que desde la experimentación misma. En efecto, ambos insisten en sus textos teóricos en la importancia de la innovación técnica desde la producción misma, y son reacios a proponer cambios que se acoten al contenido de la obra, cuestionando aquellas producciones que resultan innovadoras o revolucionarias desde sus temas - esto es, desde aquello que dicen- sin cuestionar su forma ni su técnica, ya sea de producción o de circulación. Para Kosuth, mientras hagamos pinturas estamos aceptando mucho más sobre el arte de lo que podamos cuestionar con el contenido de nuestras pinturas (Kosuth, 1991, p. 18). En Benjamin, mientras que los filósofos no atiendan a la cuestión de la exposición y se limiten al desarrollo conceptual y a la creación de sistemas, y mientras que no desafíen el limitado campo al que fueron restringidos, estarán aceptando de la tradición de la filosofía mucho más de lo que pueden cuestionar en el seno mismo de sus argumentaciones o en la elección de los temas.

En palabras de Benjamin, mientras la filosofía esté determinada por "el concepto decimonónico de sistema [Systembegriff]” (Benjamin, 2006, p. 224; GS I 207),

corre el peligro de acomodarse a un sincretismo que intente atrapar la verdad en una tela de araña tendida entre distintos conocimientos, como si aquélla viniera volando de fuera [als käme sie von draußen herzugeflogen]. (...) Si la filosofía, no en cuanto introducción mediatizadora [vermittelnde Anleitung zum Erkennen], sino en cuanto exposición de la verdad [Darstellung der Wahrheit], quiere conservar la ley de su forma, tiene que conceder la correspondiente importancia al ejercicio [ $\ddot{U b u n g}]$ mismo de esta forma, pero no a su anticipación en el sistema (Benjamin, 2006, p. 224; GS I 207-208) 
Más allá de estas coincidencias, también hay cruces significativos que demarcan tensiones complejas entre el arte y la filosofia: en Kosuth, el arte se desmaterializa y elimina la visualidad, mientras que en Benjamin la filosofía se acerca a la materialidad y trabaja visualmente. Como menciona Lindner, “en ocasión del trabajo con Dirección única, Benjamin habló de la concreción extrema a la cual aspiraba" (2014, p. 68). Esta concreción, siempre en tensión con la forma más tradicional de filosofar, esto es, la reflexión abstracta que tiende a la universalización, adquiere en el libro que tratamos aquí la forma de un montaje, es decir, de una construcción. Así, imagen y construcción, con su espacialidad propia, encuentran sitio en la filosofía, donde tradicionalmente no es admitida ninguna corporalidad.

Esta suerte de encarnación de la filosofía no es un detalle menor, en la medida en que configura un espacio de cruce con el campo artístico. Teniendo en cuenta el caso específico de la obra de Kosuth, mientras que esta última busca huir de los anclajes físicos tradicionales y redefinir el arte en función de su relación con el concepto, de la mano de Benjamin, la filosofía reconoce las limitaciones propias del trabajo conceptual y busca nuevas posibilidades de decir. Paradójicamente, y como mencionamos, en el proceso de desmaterialización del arte, en el caso concreto de la obra de Kosuth que analizamos aquí, la filosofía encuentra espacio para operar una forma de materialización que le permite impactar en la ciudad de una forma a la que el libro no puede aspirar.

Asimismo, mientras Kosuth da cuenta del fin de la filosofía en su forma tradicional (a la vez que encuentra modos de darle lugar en la esfera pública), Benjamin tematiza muy claramente la decadencia del aura y, con ella, de la forma tradicional de arte, y da cuenta de procesos cuya prolongación es el surgimiento del arte conceptual tal y como lo presenta Kosuth.

"La pregunta filosófica sobre la naturaleza del arte surgió dentro del arte", escribe Danto, "cuando los artistas insistieron, presionaron contra los límites (...) y descubrieron que 
éstos cedían. (...) Y aquello que borraron nos ha dejado en la situación en la que nos encontramos hoy" (Danto, 2010, p. 36). Como en el arte, en la filosofía el juego con el límite, contra el límite y más allá del límite, como lo supieron Wittgenstein y Benjamin ${ }^{260}$, es una estrategia de escape cuando los paradigmas sofocan. Y así como Kosuth sostiene que después de Duchamp el arte comienza a hablar otro lenguaje, podríamos decir de Benjamin que le da a la filosofía la posibilidad de hacer lo mismo.

Finalmente, el fin de la filosofía y el comienzo del arte, del que hablaba Kosuth, podría describirse también como un "fin del arte y comienzo de la filosofía" en los términos de Danto $(2010)^{261}$ o quizá, más precisamente, como el ocaso tanto del arte cuanto de la filosofía como compartimentos estancos y su conversión en espacios nuevos, indefinibles y, por eso, fascinantes, en los que se "renuevan las formas de preguntar, traducir y trabajar con lo incomprensible o lo sorprendente" (García Canclini, 2010, p. 47). Al fin y al cabo, como dijera Benjamin, "una obra significativa o funda el género como tal o lo supera, y en las perfectas se unen ambas cosas" (Benjamin, 2006, p. 242; GS I 225).

\subsection{Consideraciones finales}

Lo que no se puede describir se debería inscribir en la forma artística como una misteriosa forma de distorsión.

Slavoj Žižek, 2008, p. 30

Como intentamos mostrar en este capítulo, el estilo de Benjamin, lejos de serle accesorio a su actividad intelectual, le es constitutivo. En efecto, la denuncia de una crisis de

\footnotetext{
${ }^{260}$ Si bien Benjamin y Wittgenstein fueron contemporáneos, no tuvieron intercambios ni hay registros de que se hayan conocido ni leído. Aun así, la afinidad entre sus filosofías fue advertida ya en los años 60 por Adorno (al respecto ver su Teoría estética, publicada como es sabido póstumamente, en 1970). Sobre posibles puentes entre el pensamiento de estos dos grandes filósofos ver Cavell (1999) y Gabrielli (2004). En español puede consultarse Delgado Rojo (2015).

261 “¿Qué pasa con el arte después del fin del arte, donde con 'arte después del fin del arte', significó 'tras el ascenso a la propia reflexión filosófica'?” (Danto, 2010, p. 36).
} 
la experiencia y de una estetización de la política en su tiempo, que proponemos entender como excediendo el ámbito de la política para convertirse en una denuncia de los modos estetizados de operar también en otros ámbitos, son espacios donde puede observarse su preocupación por encontrar maneras de hacer filosofía que no oculten las grietas, opacidades y sinsentidos del mundo.

En este sentido, intentamos en este capítulo dar cuenta de sus intentos por construir "un modo de escritura que sea capaz de permanecer fiel al movimiento de interrupción o suspensión" (Ceserani, 2010, p. 89) que propone en sus tesis. Operando importantes corrimientos, fundamentalmente evitando la construcción sistemática, la progresión sin fisuras de una idea a otra y la fijación en lo conceptual, Benjamin fue capaz de construir una forma de exposición "no teoretiforme" (Rendueles, 2013, p 169), en tanto "entendió que el tipo peculiar de comprensión que proporciona la filosofía ya no necesita de la ficción de sistematicidad" (Rendueles, 2013, p. 170) ${ }^{262}$. Y es que Benjamin intentó, con su escritura, no pintar una imagen del mundo que colaborara con la ilusión que lo muestra como una máquina funcionando perfectamente, y comprendió que la tentación de esa estetización no podía evitarse simplemente cambiando los motivos de la reflexión. En efecto, y como menciona Adorno en torno al género del ensayo, "la tendencia positivista general, que contrapone rígidamente al sujeto todo objeto en cuanto objeto de investigación, se queda, en este como en todos los demás momentos, en la mera separación de forma y contenido" (2003, p. 13).

Si bien el desarrollo de este tema está fuera de los objetivos de esta investigación, es importante señalar que, si bien la filosofía, como menciona Lysaker (2014), nunca se ha fijado a un género literario específico, "el artículo profesional se ha convertido en el modelo por defecto de la filosofía, prevaleciendo con la inercia del hábito" $(2014 \text {, p. 522) })^{263}$. Rorty, por su

\footnotetext{
${ }^{262}$ También Vera Barrios refiere a esta característica cuando sostiene: "Más que llegar a un sistema, más que controlar los alcances de una serie de tesis, su pensamiento deviene potencia, posibilidad, apertura" (p. 19).

${ }^{263}$ Las discusiones sobre la preeminencia del formato del paper en filosofía son bien interesantes. Por ejemplo, han atendido a las formas de escritura y presentación de la filosofía filósofos como Cunningham (1985), Rorty
} 
parte, argumenta que la filosofía puede ser comprendida como un tipo de escritura, aun cuando muchos filósofos hayan tenido una relación con esta actividad muy diferente de la que con ella tejen los literatos. En sus palabras: "es característico de la tradición kantiana que, por mucho que escriba, no cree que la filosofía deba ser escrita mucho más de lo que debe ser escrita. Escribir es una necesidad lamentable" (1978, p. 146). Rorty también considera que, en alguna medida, la escritura filosófica, en sus versiones más sistemáticas y ambiciosas, pretende muchas veces "poner fin a la filosofía resolviendo todos sus problemas, haciendo que todo caiga en su sitio" (p. 145).

En el caso de Benjamin las cosas no pueden ser más diferentes: en su escritura se revela la búsqueda de aquello que salve a la filosofía de verse abandonada a "la simple existencia de este mundo, la del presentismo y del dominio de la subjetividad del yo" (Dimópulos, 2017, p. 148) y, con ella, a la proclama ética vacía de contenido y de acción "que de la nada fabrica, mundialmente, una apolítica de lo indiferente" (Dimópulos, 2017, p. 160).

Por otro lado, en su obra no somos siquiera ya aquel sujeto que resuelve de una vez y para siempre, aquella humanidad que progresa triunfante. Un texto de Einbahnstraße puede ayudar a ilustrar este punto:

¿Qué es lo que se soluciona? [Was wird "gelöst”?] Las preguntas de la vida vivida, ¿no quedan atrás como un follaje que nos impedía la visión? Casi ni se nos ocurre talarlo, ni siquiera clarearlo. Seguimos avanzando, lo dejamos a nuestras espaldas y, si bien desde lejos se lo puede abarcar, queda confuso, vago y tanto más enigmáticamente embrollado [undeutlich, schattenhaft und desto rätselhafter verschlungen]. (Benjamin, 2014, p. 52; GS IV 92)

(1978), Lang (1985), Garcés Mascareñas (2013) y Derrida (1998). Cunningham ha defendido el proceso -a veces muy extenso- que lleva a un texto filosófico a su publicación, argumentando que "sin él el pensamiento filosófico tenderá hacia lo idiosincrásico y misántropo" (1985, p. 167). 
Volviendo a Lysaker, en su reflexión sobre la escritura como praxis el autor se vuelca a Benjamin y a su Calle de mano única, y considera que el libro funciona, en sus intenciones más modestas que las de los grandes sistemas filosóficos, como una intervención capaz de "revitalizar la experiencia, provocar disgusto por el statu quo y cultivar hábitos de interpretación atentos" (2014, p. 522) $)^{264}$. Para concluir, y siguiendo a Lysaker, creemos que ““el qué’ y ‘el cómo’ de la escritura de Benjamin se vuelven aún más determinados cuando se consideran junto con 'su porqué”" (p. 527) y su para qué, lo que recuerda a aquellas palabras que el mismo Benjamin cita de Nietzsche: "necesitamos historia, pero la necesitamos de una manera distinta a como la necesita el holgazán malcriado en el jardín del saber” (en Benjamin, 2009, p. 197). Quizá necesitemos filosofía de la misma manera, y no para comprenderlo todo sino para "hacer saltar, por medio de una especie de cortocircuito intelectual, chispas que iluminan súbitamente lo familiar, si es que no lo incendian" (Adorno, 2001, p. 29), como lo supo hacer Benjamin.

\footnotetext{
${ }^{264}$ Si bien excede los límites y los objetivos de esta investigación, es importante hacer mención de que más allá de la preeminencia actual del formato del paper académico, es posible observar una presencia creciente de ensayos filosóficos que ponen al alcance del lector no especialista reflexiones orientadas a los temas más variados. Entre los protagonistas de este fenómeno cabe citar a Byung-Chul Han, Agamben, Didi-Huberman o Žižek, pero también a una variedad de autores (Ahmed, Berlant, Sztulwark) que se inscriben en lo que se conoce como el "giro afectivo" [affective turn] (Solana, 2020; Lara y Enciso, 2013). En la tradición ensayística (de Simmel y Lukács, por ejemplo, como recoge Adorno), la filosofía encuentra aún una vía de actualización y un entorno propicio para su inserción en el debate público (Ceserani, 2010). Los formatos no académicos que cuentan con más tradición, a su vez, no se reducen al ensayo, sino que entre ellos habría que incluir la reseña periodística, la crítica, las columnas de opinión y los ya bien establecidos espacios de divulgación en radio y televisión. Asimismo, el fenómeno reciente de la creación de contenido específicamente filosófico en Youtube es digno de un análisis pormenorizado. Entre los filósofos más prolíficos en ese ámbito se encuentran Natalie Wynn, Ian Danskin y Oliver Thorn.
} 


\section{Conclusiones}

Quienes “creen" que tienen las respuestas a las urgencias actuales son terriblemente peligrosos.

Donna Haraway, 2019, p. 75

"Ni la materia, ni el espacio, ni el tiempo son, desde hace veinte años, lo que habían venido siendo desde siempre" (Valery, citado por Benjamin, 2015b, p. 25). Esta frase forma parte de la cita que coloca Benjamin a modo de epígrafe en su célebre escrito sobre la obra de arte. Se trata de un fragmento del ensayo "La conquista de la ubicuidad" de Paul Valery, escrito en 1928. Allí, Valery imaginaba los cambios que podían producirse en la vida y en el arte a partir de las innovaciones científicas. Lo que la frase revela es la radicalidad del modo de comprender esos cambios, en tanto no se los piensa como modificaciones más o menos importantes en un escenario cuyos aspectos básicos permanecen inalterables. A su vez, plantea:

Tal como el agua, el gas o la corriente eléctrica vienen de lejos a nuestras casas para atender nuestras necesidades con un esfuerzo casi nulo, así nos alimentaremos de imágenes visuales o auditivas que nazcan y se desvanezcan al menor gesto (...). Así como estamos acostumbrados, si no ya sometidos, a recibir energía en casa bajo diversas especies, encontraremos muy simple obtener y recibir también esas variaciones u oscilaciones rapidísimas de las que nuestros órganos sensoriales, que las recogen e integran, hacen todo lo que sabemos. No se si filósofo alguno ha soñado jamás una sociedad para la distribución de la realidad sensible a domicilio. (Valery, 1999, pp. 131-132. El enfatizado es nuestro)

La elección del texto, por parte de Benjamin -el filósofo que imaginó, como ningún otro, dicha distribución-, no es casual: el tema de su propio escrito es el mismo, y su enfoque 
es igualmente radical, en la medida en que cuestiona también otro de los presupuestos que podrían haber funcionado como telón de fondo sobre el cual representar los cambios. En efecto, su obra revela que ni el espacio, ni el tiempo, ni el ser humano son ya lo que habían venido siendo desde siempre. Volvamos a las palabras del propio Benjamin, aunque con un nuevo énfasis: "dentro de largos períodos históricos, junto con el modo de existencia de los colectivos humanos [der gesamten Daseinsweise der historischen Kollektiva], se transforma también la manera de su percepción sensorial” (2015b, p. 30; GS I 478).

Y es que Benjamin fue, sin dudas, un pensador de las transformaciones no sólo en relación al arte, sino también, y fundamentalmente, en un sentido mucho más amplio, en tanto estuvo siempre, como afirma Kang "preocupado por las tecnologías innovadoras, las nuevas generaciones y las nuevas formaciones y posibilidades políticas” (Kang, 2014, p. 5). En esta investigación hemos intentado dar cuenta de este rasgo en función de tres ejes que conforman las tres secciones de la tesis y que pasaremos a recapitular brevemente.

En la primera sección, centrada en el fenómeno de la estetización, rastreamos los usos y definiciones de ese concepto y propusimos pensar a Benjamin como el filósofo que logra dar cuenta, más acabadamente, de la forma en que nuestro alejamiento del mundo desemboca, no sólo en la estetización de la política, sino también en la estetización del pasado. Como atendimos en el primer capítulo, si bien el problema de la estetización se relaciona, en la actualidad tanto como en la primera mitad del siglo XX, con la belleza y con el espectáculo, su columna vertebral es un tipo de vivencia específica estructurada en torno a la distancia contemplativa.

En efecto, si bien los procesos de estilización de las mercancías y en general del entorno -con su insistencia en la prelación de la belleza-, por un lado, y la puesta en escena como apuesta indiscutible del poder, por el otro, fueron comprendidos con razón como procesos de estetización, una indagación más profunda deja entrever la actitud distanciada y pasiva que está 
en su base. Como expusimos, Georg Simmel da cuenta muy tempranamente de esta transformación en la forma en que nos relacionamos con el mundo, y lo hace no tanto por medio de una teoría acabada, sino en sus observaciones más dispersas de fenómenos tales como la Exposición de Berlín, las costumbres a la hora de comer y el modo en que opera la categoría de paisaje, importada del arte, en los cambios que tienen lugar en nuestra percepción.

En la senda abierta por estas preocupaciones, Benjamin politiza el concepto, que enuncia en el ensayo sobre la obra de arte pero que guarda relación, como argumentamos, con escritos anteriores y posteriores. Benjamin analiza la estetización de manera explícita en el ámbito del arte y su relación con la política y, menos explícitamente, en torno al modo de implicación con el pasado en sus Tesis "Sobre el concepto de historia”. En ambos casos, indica como tarea la politización, entendida como aquello que es menester activar para hacer frente al modo en que nuestra realidad se convierte en un siniestro espectáculo que contemplamos maravillados y en el cual el pasado es venerado en sus logros y sus hitos, en aquellos documentos de la cultura que son también los de la barbarie.

En la segunda sección, y dado que la tarea de la politización implica siempre una experiencia transformadora con las obras, con el pasado y con los otros, propusimos un recorrido por algunos textos de Benjamin para dar cuenta, por un lado, del diagnóstico de la crisis o empobrecimiento de la experiencia que vio como la signatura de su tiempo y, por el otro, de la reconfiguración y la redefinición de las que es objeto la experiencia en su obra. En este contexto, argumentamos que, lejos de filosofar en el mero lamento, Benjamin trata de iluminar los cambios que vislumbra en su tiempo con el ojo puesto siempre en los peligros, pero también en las potencialidades.

Dichos cambios, peligros y potencialidades son también objeto de la tercera sección de la tesis, en la que nos preguntamos por las posibilidades y las tareas de la filosofía. Allí enfrentamos, por un lado, los diagnósticos benjaminianos con la perspectiva de Martin 
Heiggeder, en tanto consideramos que su apuesta filosófica constituyó también un intento de dar cuenta, desde el trabajo con el lenguaje -con ese lenguaje que tensan y retuercen los giros de su producción- de aquellas modificaciones estructurales que dieron su fisonomía al siglo. En Heidegger, en efecto, la preocupación por la relación del hombre con el mundo -aquel mundo que en la modernidad se transfigura en imagen- resulta central, y los ámbitos del arte y de la historia se convierten en zonas propicias para su exploración. La filosofía de Heidegger se da, así, también como respuesta a una época, y lo hace en la forma de un preguntar incansable. Sin embargo, la apuesta por la politización de la relación con el mundo, central en Benjamin y en los más acalorados debates actuales -en la politización del arte y de la historia, pero también en la politización de lo vida privada-, deja lugar en Heidegger, por un lado, a la huida hacia un pensamiento poetizante $\mathrm{y}$, por el otro, al sabor amargo de un compromiso político ruin.

Finalmente, en el último capítulo de la tesis, nos adentramos en la forma de escritura de Benjamin y sostuvimos que puede entenderse como la búsqueda de formas de decir que sean capaces de denunciar la estetización generalizada y la crisis anestesiante de la experiencia. En efecto, en Benjamin la vocación de sistema y el ansia de explicación que supieron caracterizar a la filosofía son abandonadas en pos de la exploración de recursos que permitan mostrar una realidad cambiante y siempre incompleta que no obedece a leyes universales. A su vez, en esta exploración nuestro autor se aleja del esquema compartimentado en que se entienden los saberes y se acerca a modos transdisciplinarios de operar que alojan también algunas experiencias artísticas como la de Kosuth.

Para concluir, nos interesa volver a enfatizar dos aspectos de la filosofía de Benjamin que presentan especial actualidad, a saber, por un lado, su conceptualización misma del cambio $y$, por el otro, el modo en que fue capaz de dar cuenta de las transformaciones radicales que tienen lugar allí donde la filosofía buscó un anclaje seguro, es decir, en el sujeto. Si bien un 
abordaje detallado de estas problemáticas excedería los objetivos y los límites de este trabajo, se trata de dos temas que se relacionan con la problematización de la relación estetizada con el mundo y de la crisis y reconfiguración de la experiencia que han sido los tópicos centrales de nuestra investigación.

En efecto, el pensamiento del cambio y de la novedad está atravesado habitualmente, no sólo en la filosofía sino también en el sentido común, por una comprensión del tiempo en la que el pasado, el presente y el futuro son etapas que se suceden una tras otra. En este marco, las transformaciones son comprendidas de un modo progresivo, y los procesos son proyectados al futuro en busca de vislumbrar su forma final o sus efectos últimos. Este modo de pensar el cambio da por resultado, en ocasiones, o bien la creencia en un futuro mejor y más feliz para la humanidad, o bien en un pensamiento de "la catástrofe inminente [der bevorstehenden Katastrophe]" (Benjamin, 2014, p. 55; GS IV 98) que lee la historia en clave escatológica.

Siendo uno de los pensadores que más radicalmente cuestionó su propia época, Benjamin no cayó en estas trampas, ni hizo causa común con la nostalgia conservadora que signó su tiempo tanto como signa, a veces, el nuestro. A su vez, fue ajeno al pensamiento dogmático que supone leyes necesarias que dominan el desarrollo. Entre estas construcciones ideológicas, se sorprende especialmente ante la confianza en que las cosas no empeoran nunca más allá de un cierto punto. En sus palabras:

La expectativa de que así no se puede seguir se rendirá algún día ante la evidencia de que, para el sufrimiento, tanto del individuo como de la comunidad, sólo existe una frontera más allá de la cual no se puede seguir: la aniquilación [die Vernichtung]. (Benjamin, 2014, p. 56; GS IV 99)

Atento a la urgencia de ciertas tareas, y ajeno a lecturas de la historia que la contemplan buscando a qué punto se dirige, Benjamin propuso "superar el concepto de progreso y el de período de decadencia como las dos caras de lo mismo" (2013, p. 740). Es así que los cambios 
que signan el siglo XX serán comprendidos por fuera de cualquier linealidad, y su potencialidad será atendida en términos de su capacidad de romper con la continuidad y generar una transformación. El afán de detención, que acarrea la violencia de destruir el aparente equilibrio de la totalidad, la progresión y la contemplación se convierte así en uno de los signos de su filosofía, desde la crítica hasta la reflexión explícitamente política, entendida como una exigencia en la época de esa estetización de la política que se esconde "tras la máscara del arte puro, o al menos tras la máscara del pacifismo" (Dimópulos, 2017, p. 53). En efecto, la transformación implica siempre un elemento de destrucción, en tanto como señala Andersson, “para Benjamin, destrucción siempre significó la destrucción de ciertas formas de experiencia (...) como condición productiva de la construcción de una nueva relación con el objeto" (2014, p. 363$)^{265}$.

Collingwood-Selby, por su parte, acercando la filosofía de Benjamin a la de Derrida, sostiene que

sólo hay acontecimiento allí donde lo que sucede, lo que ha sucedido, desborda y amenaza los mecanismos, los sistemas y hábitos de la percepción y de la memoria consciente que le permitirían al presente apropiarlo, transformarlo en objeto de conocimiento, repetirlo, contenerlo, inventariarlo, etcétera. (2012, p. 57)

Los momentos en que, en la interrupción de la linealidad de la historia, en la ampliación de la percepción o en la crítica de la tradición se logra dar cuenta de ese algo olvidado o desconocido y se le permite irrumpir, son los que tienen un potencial revolucionario, en tanto “destruyen y desmontan la unidad ilusoria en que están atrapadas las cosas” (Andersson, 2014, p. 385). En dicho marco, “la 'politización del arte' no es, como lo quiere el arte comprometido, un instrumento de fecundación de la conciencia izquierdista, sino la interrupción súbita de todo

\footnotetext{
${ }^{265}$ El autor agrega aquí "falsas o engañosas" (Andersson, 2014, p. 363). Lo omitimos, en tanto la idea de “experiencia falsa o engañosa" se revela problemática.
} 
programa concientizador, sin importar en qué dirección trabaje ese programa” (Galende, 2009, p. 200).

Esta forma de conceptualizar y de mostrar las transformaciones en la vida social y política se cruza con el otro rasgo de la filosofía de Benjamin que nos interesa destacar aquí, a saber, su cuestionamiento radical del sujeto y de la conciencia como instancias históricamente privilegiadas en la conceptualización de la experiencia. En el marco de este cuestionamiento, Benjamin se vale, como expusimos, de todas aquellas experiencias que son capaces de desmentir la ficción que implica ese "yo" ordenador, de todas esas grietas de la voluntad. Así, los sueños, las experiencias con drogas, la memoria involuntaria, el inconsciente, la magia, el azar, la mística, la irrupción del pasado y todas las instancias en las que el cuerpo adquiere prelación de forma decisiva frente al sistema de la conciencia serán parte de una comprensión de la vida "que se sitúa al otro extremo de ese amortiguamiento de la sensorialidad primaria que hace de soporte al programa de autonomización de la esfera estética" (Galende, 2009, p. 188).

La contemplación estética es una forma específica de organizar la experiencia que estructura, a la vez, la comprensión del sujeto como observador y de lo contemplado en su carácter de exterioridad radical. Benjamin lo ilustra en un texto breve titulado "La lejanía y las imágenes" [Die Ferne und die Bilder], de 1933. Allí, describe un paisaje que observa en la lejanía -el mar suave como un espejo, el bosque silencioso, los castillos en ruinas, el cielo azul (GS IV 427)- y, a continuación, enumera las formas en que la agencia de esa naturaleza desafía esta percepción. En sus palabras: "cada ala de pájaro que lo roza, cada ráfaga de viento que lo recorre, cada cercanía que lo alcanza, lo desmiente" (GS IV 427). Ante esto, el observador "debe olvidar todo eso, para entregarse a las imágenes [den Bildern sich zu überlassen]" (GS IV 427). 
En lugar de aquel soñador que contempla a la distancia las maravillas de la creación, Benjamin nos propone pensarnos, como vimos, como ese contemporáneo desnudo que, como Baudelaire, grita de espanto en los sucios pañales de su época. En efecto, el siglo XX ha supuesto sin duda un cuestionamiento del rol del sujeto e incluso de su misma postulación. Desde planteamientos de carácter epistemológico hasta reivindicaciones políticas, pasando por propuestas de corte ontológico, ético y estético, la filosofía -aunque no sólo ella- se ha caracterizado por una fuerte tendencia de huida del humanismo y por poner en marcha un descentramiento del sujeto cuya importancia es, todavía, difícil de establecer con claridad.

Se ha abierto entonces, tras la muerte del sujeto, la era de lo posthumano (Kraniauskas, 2012, p. 216), y la filosofía ha andado y anda a tumbos, más o menos certeros según el caso, por dar con una llave que le permita dar cuenta de aquel resto de ser humano con el que nos encontramos cotidianamente y que, traduciendo al lenguaje de Heidegger, somos en cada caso nosotros mismos.

En este escenario, la tarea de realizar un cuestionamiento radical de lo humano tal y como late a la base de muchas de nuestras concepciones encuentra en Benjamin un punto de partida por demás sugerente. En un texto de 1929 incluido entre sus primeras "Sombras breves", por ejemplo, sostiene:

El asunto es así: la pretendida imagen interior [das sogenannte innere Bild] que (...) llevamos en nosotros mismos es, de un minuto para otro, pura improvisación. Se orienta enteramente, por así decirlo, según las máscaras que le son presentadas [nach den Masken, die ihm vorgehalten werden]. El mundo es un arsenal de esas máscaras (...) Por eso nada nos hace más felices que si alguien se nos acerca con un arca de máscaras exóticas y nos ofrece los ejemplares más raros, la máscara del asesino, la del magnate de las finanzas, la del viajero que da la vuelta al mundo. Mirar a través de ellas nos encanta [Durch sie hindurchzublicken verzaubert uns]. (Benjamin, 1989c, p. 148; GS IV 372-273) 
El motivo de las máscaras es un motivo proustiano, como se revela en el baile de máscaras de El tiempo recobrado, y lo es tanto como el cuestionamiento radical del yo. En un pasaje célebre de El mundo de Guermantes, dirá el narrador a raíz de Francisca:

Una persona no está (...) clara e inmóvil ante nosotros, con sus defectos, sus proyectos, sus intenciones respecto a nosotros (...) sino que es una sombra en que jamás podremos penetrar, para la cual no existe conocimiento directo (...) -una sombra en la que podemos alternativamente imaginarnos con asaz verosimilitud que brillan el odio como el amor-. (Proust, 1999, p. 59)

En Benjamin, como en Proust, el hechizo del sujeto está roto, aun cuando las tentativas conservadoras se esfuercen por no elaborar esa pérdida y pongan en marcha operaciones galvanizantes para reanimar aquella "imagen propia del hombre tradicional, siempre solemne y noble, adornado con todas las diversas ofrendas del pasado" (2007a, p. 219). Efectivamente, el intento por conservar al viejo sujeto de la experiencia, aquel que logra crecer y fortalecerse atravesando etapas y aprendiendo de los mayores no es más que una desesperada tentativa de huida de las transformaciones y las opacidades que nos signan y que, para Benjamin, deberíamos aceptar.

Asimismo, y como denuncia Žižek ${ }^{266}$, el mito de un ser humano fuerte y heroico es alimentado por la máquina ideológica de las industrias culturales, que constituyen la educación sentimental y política a la que la vida contemporánea nos somete día a día, y -agregaremospor la creciente industria de la autoayuda con sus diferentes propuestas de optimización del yo.

Ante estos retornos, vale la pena hacer el esfuerzo de "ejercitar la habilidad para aceptar la realidad desfetichizada del sujeto: observar la oquedad, la oscuridad, sin completarla con el contenido fantasmático de la vida interior que brilla tras ella" (Žižek, 2008, p. 20), escapando de la profundidad introspectiva de la conciencia que la filosofía ha heredado de su tradición.

${ }^{266} \mathrm{Al}$ respecto, recomendamos consultar Rendueles (2014). 
Cabe preguntarse, en fin, si quizá la tarea, tanto para el arte como para la filosofía, haya dejado de ser hace rato crear conciencia, y sea ya hacer un esfuerzo sobrehumano -o posthumanopor destruir algo de esa conciencia que con tanto trabajo nos habíamos creado. 


\section{Referencias bibliográficas}

- Abadi, F. (2014). Conocimiento y redención en la filosofía de Walter Benjamin. Buenos Aires: Miño y Dávila.

○ Abadi, F. (2015). La ampliación del concepto de experiencia en Benjamin: de Kant al surrealismo en Eikasia, No 67, pp. 193-211.

○ Abensour, M. (2010). De La Compacidad - Arquitecturas y regímenes totalitarios, en Revista de Estudios Sociales 35, pp. 148-166.

- Acosta, M.; Quintana, L. (2010). De la estetización de la política a la comunidad desobrada, en Revista de ciencias sociales, Dossier Estética y política II, pp. 53-65.

- Adorno, T. (2001). Dirección única de Benjamin, en Adorno, T. (2001) Sobre Walter Benjamin. Madrid: Cátedra, pp. 28-34.

○ Adorno, T. (2003). El ensayo como forma, en Adorno, Th. (2003). Notas sobre literatura. Obra completa, 11. Madrid: Akal.

○ Adorno, T. (2003b). En recuerdo de Eichendorff, en Adorno, Th. (2003). Notas sobre literatura. Obra completa, 11. Madrid: Akal.

○ Adorno, T. (2006). Ópera burguesa, en Escritos Musicales I-III. Madrid: Akal, pp. 25-39.

○ Adorno, T.; Benjamin, W. (1994). Correspondencia (1928-1940). Madrid: Trotta.

○ Agamben, G. (2005). Profanaciones. Buenos Aires: Adriana Hidalgo.

○ Agamben, G. (2011). Infancia e historia. Buenos Aires: Adriana Hidalgo.

- Ahmed, S. (2019). La promesa de la felicidad. Una crítica cultural al imperativo de la alegría. Buenos Aires: Caja Negra.

○ Aira, C. (2001). La utilidad del arte, en Revista Ramona, pp. 4-5.

○ Amat, M. (2018). Landschaft, en Müller y Reitz (2018). Simmel-Handbuch. Begriffe, Hauptwerke, Aktualität. Frankfurt am Main: Suhrkamp, pp. 347- 352.

- Amengual, G. (2008). Pérdida de la experiencia y ruptura de la tradición. La experiencia en el pensamiento de Walter Benjamin, en Amengual, G. y otros (2008). Ruptura de la tradición. Madrid: Trotta, pp. 29-60.

○ Amengual, G.; Cabot, M.; Vermal, J. L. (2008). Introducción, en (2008). Ruptura de la tradición. Madrid: Trotta. 
○ Andersson, D. (2014). Destrucción/Construcción, en Opitz, M y Wizisla, E. (2014). Conceptos de Walter Benjamin. Buenos Aires: Las cuarenta, pp. 361-415.

○ Andrade, M. M. (2009). Los peligros de la estética en "La obra de arte en la época de su reproductibilidad técnica". Revista de Estudios Sociales, 34, pp. 70-82.

○ Arendt, H. (1990). Walter Benjamin. 1892-1940, en Arendt, H. (1990). Hombres en tiempos de oscuridad. Barcelona: Gedisa.

○ Aulinger, B. (2017). Georg Simmel (1858-1918), en Steuerwald, C. (Hg.) Kunst und Gesellschaft. Mainz: Springer, pp. 97-130.

- Barbisan, L. (2017). Eccentric Bodies: From Phenomenology to Marxism - Walter Benjamin's Reflections on Embodiment, en Anthropology \& Materialism, Special Issue I.

○ Barck, K. (1999). Konjunktion von Ästhetik und Politik oder Politik des Ästhetischen? en Barck, K. y Faber, R. (1999) (comp.), Ästhetik des Politischen - Politik des Ästhetischen. Würzburg: Königshausen und Neumann, pp. 96-118.

○ Barck, K. (2000). Ästhetisierung, en Ästhetische Grundbegriffe: Historische Wörterbuch in sieben Bänden, ed. Karlheinz Barck. Stuttgart: J. B. Metzler.

○ Barck, K.; Faber, R. (1999) (comp.), Ästhetik des Politischen - Politik des Ästhetischen. Würzburg: Königshausen und Neumann.

- Baudelaire, C. (1976). Le public moderne et la photographie, en Baudelaire, C. (1967). Critique d'art suivi de Critique musicale. Paris: Gallimard.

○ Benjamin, A. (1994). Time and task. Benjamin and Heidegger Showing the Present, en Benjamin, A., Osborne, P. (comps.) (1994). Walter Benjamin's Philosophy. Destruction and Experience. New York: Routledge.

○ Benjamin, A.; Osborne, P. (comps.) (1994). Walter Benjamin's Philosophy. Destruction and Experience. New York: Routledge.

- Benjamin, A.; Vardoulakis, D. (2015a). Introduction, en Sparks Will Fly: Benjamin and Heidegger. New York: State University of New York Press, pp. xi-xiv.

○ Benjamin, A.; Vardoulakis, D. (eds.) (2015). Sparks Will Fly: Benjamin and Heidegger. New York: State University of New York Press.

○ Benjamin, W. (1966). Briefe, ed. por G. Scholem y Th. Adorno. Frankfurt am Main: Suhrkamp.

○ Benjamin, W. (1972-1989). Gesammelte Schriften, 7 vols., ed. por R. Tiedemann y H. Schweppenhëuser. Frankfurt am Main: Suhrkamp. 
- Benjamin, W. (1989a). Discursos interrumpidos I. Filosofia del arte y de la historia, trad. J. Aguirre, Madrid: Taurus.

- Benjamin, W. (1989b). El carácter destructivo, en Benjamin, W. (1989a). Discursos interrumpidos I. Filosofia del arte y de la historia. Madrid: Taurus, pp. 157-162.

- Benjamin, W. (1989c). Sombras breves, en Benjamin, W. (1989a). Discursos interrumpidos I. Filosofía del arte y de la historia. Madrid: Taurus, pp. 141-154.

○ Benjamin, W. (1998). Onirokitsch, en R. Ibarlucía, Onirokitsch: Walter Benjamin y el surrealismo, Buenos Aires: Manantial, pp. 111-117.

- Benjamin, W. (2001a). Teorías del fascismo alemán, en Benjamin, W. (2001). Para una crítica de la violencia y otros ensayos. Madrid: Taurus, pp. 47-58.

- Benjamin, W. (2006). El origen del Trauerspiel alemán en Benjamin, W. (2006b). Obras I.1. Madrid: Abada, pp. 217-459.

o Benjamin, W. (2006b). Obras I.1. Madrid: Abada.

○ Benjamin, W. (2007). Obras II.I, trad. J. Barja, F. Duque y F. Guerrero, Madrid: Abada.

○ Benjamin, W. (2007a). Experiencia y pobreza, en Benjamin, W. (2007). Obras II.1, pp. 216-221.

- Benjamin, W. (2007b). El surrealismo. La última instantánea de la inteligencia europea, en Benjamin, W. (2007). Obras II.1, pp. 301-316.

○ Benjamin, W. (2007c). Hacia la imagen de Proust, en Benjamin, W. (2007). Obras II.1. Madrid: Abada, pp. 317-331.

○ Benjamin, W. (2007d). Sobre el programa de la filosofía venidera, en Benjamin, W. (2007). Obras II.1. Madrid: Abada, pp. 162-174.

○ Benjamin, W. (2007e). Pequeña historia de la fotografía, en Benjamin, W. (2007). Obras II. 1. Madrid: Abada, pp. 377-402.

○ Benjamin, W. (2007f). Experiencia, en Benjamin, W. (2007). Obras II.1. Madrid: Abada, pp. 54-56.

○ Benjamin, W. (2007g). Diálogo sobre la religiosidad del presente, en Benjamin, W. (2007). Obras II.1. Madrid: Abada, pp. 17-35.

- Benjamin, W. (2008). El narrador. Santiago de Chile: Metales Pesados.

O Benjamin, W. (2008b). Obras I.2. Madrid: Abada. 
- Benjamin, W. (2008c). Charles Baudelaire. Un lírico en la época del altocapitalismo en Benjamin, W. (2008b). Obras I.2. Madrid: Ababa.

○ Benjamin, W. (2008d). Paul Valéry, en Benjamin, W. (2008b). Obras I.2. Madrid: Ababa.

o Benjamin, W. (2009). Sobre el concepto de historia, en Reyes Mate, M. (2009). pp. 49-302.

O Benjamin, W. (2009a). Obras II.2. Madrid: Abada.

○ Benjamin, W. (2009b). El autor como productor, en Benjamin, W. (2009a). Obras II.2. Madrid: Abada, pp. 297-315.

- Benjamin, W. (2009c). Eduard Fuchs, coleccionista e historiador, en Benjamin, W. (2009a). Obras II.2. Madrid: Abada, pp. 68-109.

- Benjamin, W. (2010a). Destino y carácter, en Ensayos escogidos, traducción de H. A. Murena. Buenos Aires: El Cuenco de Plata, pp. 181-190.

○ Benjamin, W. (2010b). El pañuelo, en Benjamin, W. (2010c). Obras IV.2. Madrid: Abada.

○ Benjamin, W. (2010d). Infancia en Berlín hacia el mil novecientos, en Benjamin, W. (2010f). Obras IV.1. Madrid: Abada.

○ Benjamin, W. (2011). Denkbilder. Epifanías en viaje. Buenos Aires: El cuenco de plata.

○ Benjamin, W. (2011a). El buen escritor, en Benjamin, W. (2011). Denkbilder. Epifanías en viaje. Buenos Aires: El cuenco de plata, p. 153.

- Benjamin, W. (2011b). El arte de narrar, en Benjamin, W. (2011). Denkbilder. Epifanías en viaje. Buenos Aires: El cuenco de plata, pp. 163-164.

- Benjamin, W. (2011c). Higos frescos, en Benjamin, W. (2011). Denkbilder. Epifanías en viaje. Buenos Aires: El cuenco de plata, pp. 95-96.

○ Benjamin, W. (2013). Obras V: Obra de los pasajes. Madrid: Abada.

○ Benjamin, W. (2014). Calle de mano única. El Cuenco de Plata, Buenos Aires.

- Benjamin, W. (2015a). Estética de la imagen: fotografía, cine y pintura, ed. T. Vera Barros, trad. A.E. Weikert, M. Dimópulos y M. López Seoane. Buenos Aires: La Marca Editora.

- Benjamin, W. (2015b). La obra de arte en la época de su reproductibilidad técnica, en Benjamin, W (2015a). pp. 25-81.

○ Benjamin, W. (2015c). Diario de Moscú. Buenos Aires: Ediciones Godot.

O Benjamin, W. (2017). Obras VI. Madrid: Abada. 
- Benjamin, W. (2017a). Hachís, primeros de marzo de 1930, en Benjamin, W. (2017). Obras VI. Madrid: Abada, pp. 773-777.

○ Benjamin, W. (2017b). Memorándum sobre la revista "Crisis y crítica", en Benjamin, W. (2017). Obras VI. Madrid: Abada, pp. 807-811.

- Benjamin, W. (2017c). Crónica de Berlín, en Benjamin, W. (2017). Obras VI. Madrid: Abada, pp. 619-684.

o Benjamin, W. (2017d). De la experiencia [fr. 59], en Benjamin, W. (2017). Obras VI. Madrid: Abada, p. 113.

- Benjamin, W. (2017e). Sobre los barcos, minas [fr. 97], en Benjamin, W. (2017). Obras VI. Madrid: Abada p. 164.

O Benjamin, W. (2017f). El gran arte [fr. 172], en Benjamin, W. Obras VI. (2017). Madrid: Abada, 283-284.

○ Benjamin, W. (2017g). Apuntes 2 [fr. 171], en Benjamin, W. Obras VI. Madrid: Abada, 2017, pp. 280-283.

○ Benjamin, W. (2017h). fr. 170, en Benjamin, W. (2017). Obras VI. Madrid: Abada, pp. 279280.

○ Berlant, L. (2020). El optimismo cruel. Buenos Aires: Caja negra.

○ Bernstein, R. J. (2012). Experience after the Linguistic Turn, en Bernstein, R. The pragmatic turn. Malden, MA: Polity.

- Berríos Guajardo, V. (2014). Prólogo y filosofía. Apuntes sobre "Ensayo de autocrítica", en Hybris. Revista de Filosofía, Vol. $5 \mathrm{~N}^{\circ}$ Especial: El arte de Dionisos. ISSN 0718-8382, Julio 2014, pp. 195-212.

○ Berti, A. (2015). Aura y técnica, en Benjamin, W. (2015a), pp. 205-218.

○ Berti, E. (2012). Prólogo del editor. En Volpi, F. (2012). Heidegger y Aristóteles. Buenos Aires: Fondo de cultura económica.

- Bezirksamt Treptow von Berlin (Ed.), (1997). Die Berliner Gewerbeausstellung 1896 in Bildern. Berlín: Berliner Debatte.

○ Böhringer, H. (2018). In der Unentschiedenheit des Lebens. Simmels Lebensphilosophie, en Müller y Reitz (2018). Simmel-Handbuch. Begriffe, Hauptwerke, Aktualität. Frankfurt am Main: Suhrkamp, pp. 844-853. 
○ Bowie, A. (1999). Cap 8. Nietzsche: la separación entre el arte y la razón, en Bowie, A (1999). Estética y subjetividad. La filosofía alemana de Kant a Nietzsche y la teoría estética actual. Madrid: Visor, pp. 221-265.

o Braidotti, R. (2013). The Posthuman. Cambridge: Polity.

- Broch, H. (1970a). Kitsch y arte de tendencia, en Broch, H. (1970). Kitsch, vanguardia y el arte por el arte. Barcelona: Tusquets.

○ Broch, H. (1970b). Notas sobre el problema del kitsch, en Broch, H. (1970) Kitsch, vanguardia y el arte por el arte. Barcelona: Tusquets.

o Buchloh, B. (1990). Conceptual Art 1962-1969. From the Aesthetic of Administration to the Critique of Institutions, en October, Vol. 55, Winter, pp. 105-143.

- Buck-Morss, S. (1995). Dialéctica de la mirada. Walter Benjamin y el proyecto de los pasajes. Madrid: La balsa de la Medusa.

○ Buck-Morss, S. (2005). Walter Benjamin, escritor revolucionario. Buenos Aires: Interzona.

- Buck-Morss, S. (2015). Estética y anestésica: una reconsideración del ensayo sobre la obra de arte, en Benjamin 2015a, pp. 159-204.

- Cabot, M. (2008). Sobre los medios técnicos y la renovación de tradiciones. Walter benjamin y el concepto de "experiencia" pensado desde la Estética, en Amengual, G. y otros (2008). Ruptura de la tradición. Madrid: Trotta.

o Calkins, E. E. (1927). Beauty the New Business Tool, en The Atlantic Monthly, n. 140, August.

- Calvente, S. B. (2017). La experiencia en la concepción del conocimiento de David Hume. Niveles personales y sociales, sentidos y funciones. Tesis de posgrado. Universidad Nacional de La Plata. Facultad de Humanidades y Ciencias de la Educación. En Memoria Académica. Disponible en: http://www.memoria.fahce.unlp.edu.ar/tesis/te.1364/te.1364.pdf

○ Capasso, V.; Bugnone, A.; Fernández, C. (Coords.) (2020). Estudios sociales del arte: Una mirada transdisciplinaria. La Plata: EDULP.

- Carrasco, N. (2017). Arte y fotografía en Walter Benjamin: raíces de una nueva controversia, en Fedro, Revista de Estética y Teoría de las Artes. Número 16, julio de 2016, pp. 156-175.

○ Castillo, J. J. (1998). Presentación: el estilo de Simmel, en Revista española de investigaciones sociológicas, N. 84 Monográfico: Sociología del arte. 
○ Cavell, S. (1999). Benjamin and Wittgenstein: Signals and Affinities, en Critical Inquiry, 25(2), pp. 235-246.

o Caygill, H. (1994). Benjamin, Heidegger and the Destruction of tradition, en Benjamin, A. y Osborne, P. (eds.) (1994) Walter Benjamin's philosophy: Destruction and experience. London: Routledge.

○ Caygill, H. (1995). Walter Benjamin: The Color of Experience. Nueva York: Routledge.

o Ceserani, R. (2010). The essayistic style of Walter Benjamin, en Primerjalna književnost (Ljubljana) 33.1, pp. 83-92.

- Chausovsky, A. (2015). Walter Benjamin y el mundo de los juguetes, en Naishtat, F., Gallegos, E. G. y Yébenes, Z. (coords.) (2015). Ráfagas de dirección múltiple. Abordajes de Walter Benjamin. Ciudad de México: UAM Cuajimalpa, pp. 261-288.

○ Cherniavsky, A. (2006). La concepción del tiempo de Henri Bergson: El alcance de sus críticas a la tradición y los límites de su originalidad, en Revista de Filosofía y Teoría Política, 2006 (37), pp. 45-68.

- Claussen, D. (2006). Theodor W. Adorno: Uno de los últimos genios. Valencia: Puv.

○ Cohen, E. (2009). Walter Benjamin y la crítica literaria, en Acta Poetica 30-2 Otoño, pp. 135-150.

- Collingwood-Selby, E. (2012). El filo fotográfico de la historia: Walter Benjamin y el olvido de lo inolvidable. Santiago de Chile: Metales Pesados.

- Comay, R. (2010). Enmarcando la redención: aura, origen, tecnología en Benjamin y Heidegger, en Uslenghi, A. (comp.) (2010). Walter Benjamin: culturas de la imagen. Buenos Aires: Eterna cadencia.

○ Cunningham, F. (1985). Writing Philosophy: Sequential Essays and Objective Tests, en College Composition and Communication, 36(2), pp. 166-172.

- Danto, A. (2010). Después del fin del arte: el arte contemporáneo y el linde de la historia. Madrid: Paidós.

- De la Fuente, E. (2008). The Art of Social Forms and the Social Forms of Art: The Sociology-Aesthetics Nexus in Georg Simmel's Thought, en Sociological Theory, Vol. 26, No. 4 (Dec., 2008), pp. 344-362.

○ Debord, G. (2002). La sociedad del espectáculo. Buenos Aires: La marca.

○ Delgado Rojo, J. L. (2015) Benjamin y Wittgenstein. Una aproximación morfológica, en Ágora. Papeles de filosofía, Vol. 34, No 1, 2015, pp. 33-57. 
○ Déotte, J-L. (2009). ¿Qué es un aparato estético? Benjamin, Lyotard, Rancière. Santiago de Chile: Metales Pesados.

- Déotte, J-L. (2013). La ciudad porosa. Walter Benjamin y la arquitectura. Santiago de Chile: Metales pesados.

○ Derrida, J. (1998). Of Grammatology. Johns Hopkins University Press.

○ Di Gregori, C., López, F. (2014). Regreso a la experiencia. Lecturas de Peirce, James, Dewey y Lewis. Buenos Aires: Biblos.

- Di Pego, A. (2015). La ambivalencia de la narración en Walter Benjamin, en Naishtat, F., Gallegos, E. G. y Yébenes, Z. (coords.) (2015). Ráfagas de dirección múltiple. Abordajes de Walter Benjamin. Ciudad de México: UAM Cuajimalpa, pp. 141-167.

○ Di Pego, A. (2017). En el umbral del post-humanismo: Walter Benjamin y el reino de las criaturas, en Intercambios, año 2, no. 3, pp. 97-124.

○ Di Pego, A. (2018). ¿El retorno del narrador? Reflexiones sobre la lectura Benjaminiana de Kafka, en Ágora. Papeles de Filosofía, 37 (1), pp. 205-233.

○ Didi-Huberman, G. (2012a). Supervivencia de las luciérnagas. Madrid: Abada editores.

○ Didi-Huberman, G. (2012b). Arde la imagen. México: Fundación Televisa.

- Dimópulos, M. (2017). Carrusel Benjamin. Ciudad Autónoma de Buenos Aires: Eterna Cadencia.

○ Dziudzia, C. (2015). Ästhetisierung und Literatur. Begriff und Konzept von 1800 bis heute. Heidelberg: Universitätsverlag.

- Echeverría, B. (2003). Introducción, en Benjamin, W. (2003). La obra de arte en la época de su reproductibilidad técnica. México: Itaca.

○ Egel, A. (2015). Who Was Friedrich Hölderlin? Walter Benjamin, Martin Heidegger, and the Poet, en Benjamin, A., Vardoulakis, D. (eds.) (2015). Sparks Will Fly: Benjamin and Heidegger. New York: State University of New York Press, pp. 177-188.

○ Elsaesser, T. (2009). Between Erlebnis and Erfahrung: Cinema Experience with Benjamin, en Paragraph, Vol. 32, No. 3, Passage-work: Walter Benjamin between the Disciplines (November 2009), Edinburgh University Press, pp. 292-312.

○ Escudero, J. (2002). Prólogo, en Heidegger, M. (2002). Interpretaciones fenomenológicas sobre Aristóteles. Indicación de la situación hermenéutica [Informe Natorp]. Madrid: Trotta. 
- Escudero, J. (2008). El programa filosófico del joven Heidegger. Introducción, notas aclaratorias y glosario terminológico sobre el tratado El concepto de tiempo. Barcelona: Herder.

- Escudero, J. (2010). Ser y tiempo y el imperativo de una estética de la existencia, en Revista de Humanidades $\mathrm{N}^{\mathrm{0}} 21$ (junio 2010), pp. 9-29.

○ Escudero, J. (2012). "Ser y tiempo”: ¿una ética del cuidado?, en Aurora, N. 13, pp. 74-9.

○ Escudero, J. (2015). El lenguaje de Heidegger: Diccionario filosófico 1912 - 1927. Barcelona: Herder.

- Espinosa, L. (2017). Figuras de la crítica en Walter Benjamin: del romanticismo alemán a Charles Baudelaire, en Alpha, $N^{\circ}$ 45, pp. 47-58.

- Farías, V. (1998). Heidegger y el nazismo. Santiago de Chile: Fondo de Cultura Económica.

○ Faye, E. (2019). Heidegger. La introducción del nazismo en la filosofía. Madrid: Akal.

○ Featherstone, M. (2007). Consumer Culture and Postmodernism. London: SAGE.

- Fenves, P. (2010). ¿Existe una respuesta a la estetización de la política?, en Uslenghi, A. (comp.) (2010). Walter Benjamin: culturas de la imagen. Buenos Aires: Eterna cadencia.

○ Fenves, P. (2011). Über das Programm der kommenden Philosophie, en Lindner, B. (Hrsg.). (2011). Benjamin Handbuch. Leben - Werk - Wirkung. Stuttgart/ Weimar: J.B. Metzler.

○ Fenves, P. (2015). Entanglement- of Benjamin with Heidegger, en Benjamin, A.; Vardoulakis, D. (eds.) (2015). Sparks Will Fly: Benjamin and Heidegger. New York: State University of New York Press, pp. 3-26.

○ Ferrer Rey, L. (2020). Bordes y desbordes: el pensamiento al límite de Jacques Rancière, en Theory Now: Journal of literature, critique and thought, Vol 3, N 1, pp. 50-62.

○ Ferris, D. (2015). Politics of the Useless: The Work of Art in Benjamin and Heidegger, en Benjamin, A.; Vardoulakis, D. (eds.) (2015). Sparks Will Fly: Benjamin and Heidegger. New York: State University of New York Press, pp. 259-281.

- Fischer, J. (2018). Psychoanalytikerin trifft Marina Abramović. Zürich: Scheidegger und Spiess.

○ Fix, U. (2001). Die Ästhetisierung des Alltags, en Zeitschrift für Germanistik, Vol. 11, No. 1 (2001), Peter Lang, pp. 36-53.

o Franck, D. (2011). Heidegger y el problema del espacio. México: Universidad Iberoamericana. 
○ Frei, N. (2007). Nach Broszat, en Frei, N. (Ed.) (2007). Martin Broszat, der 'Staat Hitlers' und die Historisierung des Nationalsozialismus. Göttingen: Wallstein.

o Friedlander, E. (2012). Walter Benjamin. A Philosophical Portrait. Cambridge/London: Harvard University Press.

- Frisby, D. (1992a). The aesthetics of modern life, en Simmel and since. Essays on Georg Simmel's Social Theory. London: Routledge, pp. 135-151.

○ Frisby, D. (1992b). A Sociological Flâneur?, en Sociological Impressionism. pp. 68-101.

o Frisby, D. (2013). Fragments of Modernity. Theories of Modernity in the Work of Simmel, Kracauer and Benjamin. New York: Routledge.

- Fujita Hirose, J. (2014). Cine-capital. Cómo las imágenes devienen revolucionarias. Buenos Aires: Tinta limón.

○ Fürnkäs, J. (2014). Aura, en Opitz y Wizisla (2014), pp. 83-157.

○ Gabrielli, P. (2004). Sinn und Bild bei Wittgenstein und Benjamin. Bern: Peter Lang.

○ Gagnebin, J. M. (1999). História e narração em Walter Benjamin. São Paulo: Perspectiva.

○ Gagnebin, J. M. (2005). Do conceito de Darstellung em Walter Benjamin ou verdade e beleza, en Kriterion, Belo Horizonte, № 112, pp. 183-190.

○ Gainza, M. (2017). El nervio óptico. Barcelona: Anagrama.

- Galende, F. (2009). Walter Benjamin y la destrucción, Metales Pesados, Santiago de Chile.

○ Galfione, M. V. (2014). Estética y política: el debate contemporáneo en torno a las formas de la representación, en Trans/Form/Ação, vol.37 no.1 Marília Jan./Apr. 2014, pp. 223- 246.

○ Gallegos, E. G. (2015). Walter Benjamin y el ciframiento político de la estética en Baudelaire, en Naishtat, F., Gallegos, E. G. y Yébenes, Z. (coords.) (2015). Ráfagas de dirección múltiple. Abordajes de Walter Benjamin. Ciudad de México: UAM Cuajimalpa, pp. 23-49.

- Gandesha, S. (2017). 'Reification' between Autonomy and Authenticity: Adorno on Musical Experience, en Gandesha, S. y Hartle, J. F. (2017). The Spell of Capital. Reification and Spectacle. Amsterdam: Amsterdam University Press.

○ Garcés Mascareñas, M. (2013). La estandarización de la escritura. La asfixia del pensamiento filosófico en la academia actual, en Athenea Digital, 13(1), pp. 29-4.1

- García Canclini, N. (2010). La sociedad sin relato. Antropología y estética de la inminencia. Montevideo: Katz Editores. 
- García, L. (2010). Alegoría y montaje. El trabajo del fragmento en Walter Benjamin, en Constelaciones. Revista de Teoría Crítica. № 2, 2010, pp. 158-185.

○ García, L. (2013). La «actualidad» de Walter Benjamin. Giorgio Agamben, Georges DidiHuberman y el problema de la temporalidad, ponencia presentada en octubre de 2013 en las Jornadas Internacionales "Actualidad de la Teoría Crítica", en Rosario, Argentina, recuperada de https://herramienta.com.ar/articulo.php?id=2131

○ García, L. (2016). Técnica, poshumanismo y experiencia, en Eidos nº 27, pp. 293-318.

○ Gelderloos, C. (2014). Simply Reproducing Reality. Brecht, Benjamin, and Renger-Patzsch on Photography, en German Studies Review 37.3 (2014), pp. 549-573.

○ Genette, G. (1997). La obra del arte. Buenos Aires: Lumen.

○ Gómez, V. (1996). ¿Literatura por filosofía? Sobre la epistemología del fragmento en Th. W Adorno, en Analas del Seminario de Metafisica, $\mathrm{n}^{\circ}$ 30. Madrid: Universidad Complutense, pp. 219-236.

○ Gornick, V. (2020). Apegos feroces. Ciudad de México: Sexto piso.

○ Greisch, J. (2010). La invención de la diferencia ontológica. Heidegger después de Ser y tiempo. Buenos Aires: Las cuarenta.

○ Guasch, A. M. (2001). El arte último del siglo XX. Del posminimalismo a lo multicultural. Madrid: Alianza.

- Gubern, R. (2006). La imagen pornográfica y otras perversiones ópticas. Barcelona: Anagrama.

○ Gunkel, D.; Taylor, P. (2014). Heidegger and the Media. Cambridge: Polity.

- Habermas, J. (1975). Walter Benjamin, en Perfiles filosófico-políticos, trad. M. Jiménez Redondo, Taurus, Madrid, pp. 297-332.

○ Han, B-C. (2014). Psicopolítica. Barcelona: Herder.

○ Hansen, M. (1987). Benjamin, Cinema and Experience: "The Blue Flower in the Land of Technology”, en New German Critique (40), pp. 179-224.

○ Hansen, M. (2007). Benjamin's Aura, en Critical Inquiry 34 (Winter 2008), pp. 336-375.

- Hansen, M. (2012). Cinema and Experience. Sigfried Kracauer, Walter Benjamin, and Theodor W. Adorno. California: University of California Press.

- Haraway, D. J. (2019). Seguir con el problema. Generar parentesco en el Chthuluceno. Buenos Aires: consonni. 
○ Hartog, F. (2013). El régimen moderno de historicidad puesto a prueba con las dos guerras mundiales, en Mudrovcic, M. y Rabotnikof, N. En busca del pasado perdido. Temporalidad, historia y memoria. México: Siglo veintiuno, pp. 51-65.

- Heidegger, M. (1935-1946). Gesamtausgabe, Band 5: Holzwege. Frankfurt am Main: Vittorio Klostermann.

○ Heidegger, M. (1967). Sein und Zeit. Tübingen: Max Niemeyer Verlag.

o Heidegger, M. (1997). La pregunta por la técnica, en Heidegger, M. (1997). Filosofía, ciencia y técnica. Santiago de Chile: Editorial Universitaria.

- Heidegger, M. (2002). Interpretaciones fenomenológicas sobre Aristóteles. Indicación de la situación hermenéutica [Informe Natorp]. Madrid: Trotta. Traducción de Jesús Adrián Escudero.

o Heidegger, M. (2006). Ser y tiempo. Trad. de Jorge E. Rivera. Madrid: Trotta.

o Heidegger, M. (2009). El concepto de tiempo en la ciencia histórica [1915], en Tiempo e historia. Madrid: Trotta.

○ Heidegger, M. (2010). La época de la imagen del mundo, en Heidegger, M. (2010a) Caminos de bosque. Madrid: Alianza, pp. 63-90.

○ Heidegger, M. (2012). El concepto de tiempo (Tratado de 1924). Traducción de Jesús Adrián Escudero. Barcelona: Herder.

- Heidegger, M. (2016). El origen de la obra de arte. Trad. de Helena Cortés y Arturo Leyte. Madrid: Alianza.

○ Heidegger, M. (2017). Reflexiones VII-XI. Cuadernos negros (1938-1939). Edición de Peter Trawny, traducción de Alberto Ciria. Madrid: Trotta.

○ Hennion, A.; Latour, B. (2003). How to Make Mistakes on So Many Things at Once - And Become Famous for It, en Gumbrecht, H y Marrinan, M. (2003). (Eds.), Mapping Benjamin. Stanford: Stanford University Press, pp. 91-97.

○ Hiebel, F. (1951). Zur Interpretation der „Blauen Blume“ des Novalis. Monatshefte, 43(7), pp. 327-334.

o Hieber, L. (2017). Walter Benjamin (1892 -1940), en Steuerwald, C. (Hg.) Kunst und Gesellschaft. Mainz: Springer, pp. 253- 280.

o Hillach, A. (1979). The Aesthetics of Politics: Walter Benjamin's 'Theories of German Fascism'. New German Critique 17, pp. 99-119. 
○ Hillach, A. (2014). Imagen dialéctica, en Opitz, M. y Wizisla, E. (2014). Conceptos de Walter Benjamin. Buenos Aires: Las cuarenta, pp. 643-708.

○ Hodge, J. (2015). Sobriety, Intoxication, Hyperbology: Benjamin and Heidegger Reading Hölderlin, en Benjamin, A., Vardoulakis, D. (eds.) (2015). Sparks Will Fly: Benjamin and Heidegger. New York: State University of New York Press, pp. 189-215.

○ Holz, H. (2014). Idea, en Opitz, M. y Wizisla, E. (2014). Conceptos de Walter Benjamin. Buenos Aires: Las cuarenta, pp. 591-641.

○ Honneth, A. (1992). Soziologie. Eine Kolumne: Ästhetisierung der Lebenswelt, en Merkur 46 , pp. 522-527.

- Honneth, A. (2007). Reificación. Un estudio de la teoría del reconocimiento. Buenos Aires: Katz.

- Honold, A. (2014). Narración, en Opitz, M y Wizisla, E. (2014). Conceptos de Walter Benjamin. Buenos Aires: Las cuarenta, pp. 793-844.

- Ibarlucía, R (2020). Belleza sin aura. Surrealismo y teoría del arte en Walter Benjamin. CABA: Miño y Dávila.

- Ibarlucía, R. (1998). Onirokitsch. Walter Benjamin y el surrealismo. Buenos Aires: Manantial.

- Ibarlucía, R. (2000). Benjamin crítico de Heidegger: hermenéutica mesiánica e historicidad, en Revista latinoamericana de Filosofía, Vol. XXVI º 1 (Otoño 2000) pp. 111-140.

○ Immanen, M. (2020). Toward a Concrete Philosophy: Heidegger and the Emergence of the Frankfurt School. Ithaca, New York: Cornell University Press.

○ Jameson, F. (1999). The Theoretical Hesitation: Benjamin's Sociological Predecessor en Critical Inquiry, Vol. 25, No. 2, "Angelus Novus": Perspectives on Walter Benjamin (Winter, 1999), pp. 267-288.

- Jauss, H. R. (1986). Experiencia estética y hermenéutica literaria. Ensayos en el campo de la experiencia estética. Madrid: Taurus.

○ Jay, M. (2003). Campos de fuerza. Entre la historia intelectual y la crítica cultural. Buenos Aires: Paidós.

○ Jay, M. (2009). Cantos de experiencia. Variaciones modernas sobre un tema universal. Buenos Aires: Paidós.

○ Jozami, E; Kaufman, A.; Vedda, M. (comps.) (2013). Walter Benjamin en la ex ESMA. Buenos Aires: Prometeo. 
- July, M. (2018). Nadie es más de aquí que tú. Barcelona: Penguin Random House.

○ Jung, W. (2016). Capítulo 6: De la velocidad y las modas. Aspectos de crítica cultural y social de la filosofía de Georg Simmel” en Vernik, E. y Borisonik, H. [eds.], Georg Simmel, un siglo después: actualidad y perspectiva, CABA: IIGG-Clacso, pp. 105-120.

○ Kang, J. (2014). Walter Benjamin and the Media. The Spectacle of Modernity. Cambridge: Polity.

○ Karczmarczyk, P. (2007). Gadamer: Aplicación y comprensión. La Plata: Edulp.

○ Kittsteiner, H. (1986). Walter Benjamin's Historicism, en New German Critique, (39), pp. 179-215.

○ Koepnick, L. (1999). Walter Benjamin and the Aesthetics of Power. Lincoln and London: University of Nebraska Press.

○ Kordela, A. K. (2015). Commodity Fetishism and the Gaze, en Benjamin, A., Vardoulakis, D. (eds.) (2015). Sparks Will Fly: Benjamin and Heidegger. New York: State University of New York Press, pp. 27-63.

○ Kösser, U. (2006). Ästhetik und Moderne: Konzepte und Kategorien im Wandel. Nürnberg: Filos.

○ Kosuth, J. (1991). Art after philosophy, en Kosuth, J. (1991). Art after Philosophy and After. Collected Writings 1966-1990. The MIT Press.

○ Kracauer, S. (1999). On the writings of Walter Benjamin, en Kracauer, S. (1999). The mass ornament. Weimar essays. Harvard University Press, pp. 259-264.

- Kraniauskas, J. (2012). Políticas literarias: poder y acumulación en la literatura y el cine latinoamericanos. México: FLACSO.

○ Kuffer, P. (2015). Imagen y origen: el lenguaje de otra historia, en Naishtat, F., Gallegos, E. G. y Yébenes, Z. (coords.) (2015). Ráfagas de dirección múltiple. Abordajes de Walter Benjamin. Ciudad de México: UAM Cuajimalpa, pp. 223-256.

○ Küpper, T.; Skrandies, T. (2011). Rezeptionsgeschichte en Lindner, B. (Hrsg.). (2011). Benjamin Handbuch. Leben - Werk - Wirkung. Stuttgart/ Weimar: J.B. Metzler.

○ Laddaga, R. (2006). Estética de la emergencia. Buenos Aires: Adriana Hidalgo Editora.

- Lanfranconi, A. (2017). Walter Benjamin: infancia y politización. Barcelona: Facultat de Filosofía, Universitat de Barcelona.

○ Lang, B. (1985). Philosophy by the letters, en The Eighteenth Century, 26(2), pp. 197-203. 
○ Lara, A; Enciso, G. (2013). El Giro Afectivo, en Athenea Digital. Revista de pensamiento e investigación social, [S.1.], v. 13, n. 3, pp. 101-120.

○ Leslie, E. (2007). Walter Benjamin. Overpowering Conformism. London: Reaktion Books.

○ Leyte, A. (2016). Prólogo, en Heidegger, M. (2016). El origen de la obra de arte. Madrid: Alianza, pp. 9-14.

○ Lijster, T. (2017). 'All Reification Is a Forgetting': Benjamin, Adorno, and the Dialectic of Reification, en Gandesha, S. y Hartle, J. F. (2017). The Spell of Capital Book. Reification and Spectacle. Amsterdam: Amsterdam University Press.

○ Lindner, B. (2011). Zu Traditionskrise, Technik, Medien, en Lindner, B. (Hrsg.). (2011). Benjamin Handbuch. Leben - Werk - Wirkung. Stuttgart/ Weimar: J.B. Metzler.

○ Lindner, B. (2014). Alegoría, en Opitz, M. y Wizisla, E. (2014). Conceptos de Walter Benjamin. Buenos Aires, Las cuarenta, pp. 17-82.

o Lindroos, K. (2001). Scattering Community: Benjamin on Experience, narrative and history, Philosophy \& Social Criticism, 11/2001, 27(6), pp. 9-41.

○ Lipovetsky, G.; Serroy, J. (2014). La estetización del mundo. Vivir en la época del capitalismo artístico. Barcelona: Anagrama. Versión para KOBO EPUB.

○ Long, C. P. (2001). Art's fateful hour: Benjamin, Heidegger, Art and Politics, en New German Critique, 83, pp. 89-115.

o López, C. (2018). El problema del tiempo histórico, el rol del historiador y la escritura de la historia. Convergencias y divergencias filosóficas en las obras de Walter Benjamin, Jacques Rancière y Reinhart Koselleck, en Hermenéutica Intercultural № 29, pp. 79-117.

○ Löwith, K. (2006). Heidegger, pensador de un tiempo indigente. Buenos Aires: Fondo de Cultura Económica.

○ Löwy, M. (2005). Walter Benjamin: aviso de incendio. Una lectura de las tesis "sobre el concepto de la historia”, trad. H. Pons, Fondo de Cultura Económica, Buenos Aires.

○ Lyotard, J. F. (1995). Heidegger y “los judios”. Buenos Aires, La Marca.

○ Lysaker, J. (2014). Writing as Praxis, en The Journal of Speculative Philosophy, 28(4), pp. 521-536.

- Mallamaci, M. G. (2018). Hacia una analítica del sensorium común. Apuntes para una morfología estético-política de lo social, en Astrolabio Nueva Época: Revista digital del Centro de Investigaciones y Estudios sobre Cultura y Sociedad, N 21, pp. 196-223. 
○ Malpas, J. (2007). Heidegger in Benjamin's city, en The Journal of Architecture, Vol. 12, Issue 5, pp. 489-497.

- Manfred Becker unter Mitarbeit von Anja Beck (2014). Die Quadriga postmoderner Beliebigkeit und ihre Folgen für Wirtschaft und Gesellschaft. Eine empirische Studie zur Entwicklung und Steuerung von Individualisierung, Fragmentierung, Temporalisierung und Ästhetisierung. München- Mering: Rainer Hampp.

- Manzo, S. (2016). Empirismo y filosofía experimental. Las limitaciones del relato estándar de la filosofía moderna a la luz de la historiografía francesa del siglo XIX (J.-M. Degérando), en Revista colombiana de filosofía y ciencia, 16 (32), pp. 11-35.

○ Marchán Fiz, S. (1994). Del arte objetual al arte de concepto (1960-1974). Madrid: Akal.

○ Marcuse, H. (1969). Un ensayo sobre la liberación. México D.F: Editorial Joaquín Mortiz.

- Martínez, A. T. (1984). Walter Benjamin, a sociologist in the path of Simmel, en Humboldt Journal of Social Relations, Vol. 12, No. 1 (Fall//Winter 1984-85), Humboldt State University, pp. 114-131.

○ Maskarinec, M. (2018). Rahmen, en Müller y Reitz (2018). Simmel-Handbuch. Begriffe, Hauptwerke, Aktualität. Frankfurt am Main: Suhrkamp, pp. 432-433.

○ McCracken, S. (2002). The Completion of Old Work: Walter Benjamin and the Everyday, en Cultural Critique, No. 52, Everyday Life (Autumn, 2002), pp. 145-166.

- Melamed, A. (2005). Ventanas, en Moran, J. (2005). Proust más allá de Proust. La Plata: de la campana.

- Melamed, A. (2006). Imitación y creación en la estética de Marcel Proust, en Moran, J. C. (2006). Proust ha desaparecido. Una memoria de los paraísos perdidos. La Plata: Prometeo.

- Melamed, A. (2010). Políticas de la imagen, del terror y de la memoria, en Moran, J. Los filósofos y los días. Escritos sobre conocimiento, arte y sociedad. La Plata, de la campana, 2010, pp. 149-159.

- Melamed, A. (2012). Una experiencia sin sujeto: Proust entre Benjamin y Heidegger, ponencia en el VIII Congreso Internacional Orbis Tertius de Teoría y Crítica Literaria, La Plata.

- Melamed, A. (2013). Palimpsestos y pasajes en la relación Proust- Benjamin. Ponencia en XVI Congreso Nacional de Filosofía de AFRA. Centro Cultural Borges, Bs. As.

- Melamed, A. (2016). Repercusiones contemporáneas de la crítica estética inmanente a la modernidad. X Jornadas de Investigación del Departamento de Filosofía FaHCE-UNLP, 19 al 21 de agosto de 2015, Ensenada, Argentina. 
○ Melamed, A. (2016b). Disolución del origen. Reflexión sobre el arte contemporáneo, en Octante 1, pp. 42-48. Recuperado a partir de http://papelcosido.fba.unlp.edu.ar/ojs/index.php/octante/article/view/164

- Melamed, A. (2018). Tiempo, espacio, memoria y tradición: le côté Ruskin de Proust en Melamed, A. (coord.) Actas de las II Jornadas Marcel Proust. Melamed, A. (2017: Ensenada). La Plata: Universidad Nacional de La Plata. Facultad de Humanidades y Ciencias de la Educación. (Trabajos, comunicaciones y conferencias). Recuperado de https://libros.fahce.unlp. edu.ar/index.php/libros/catalog/book/121

○ Melamed, A.; Staroselsky, T. (2017). El filósofo como productor. XI Jornadas de Investigación del Departamento de Filosofía FaHCE-UNLP, 8 al 11 de agosto de 2017, Ensenada, Argentina. EN: Actas publicadas. La Plata: Universidad Nacional de La Plata. Facultad de Humanidades y Ciencias de la Educación. Departamento de Filosofía.

○ Menke, C. (2011). Estética y negatividad. Buenos Aires: Fondo de cultura económica.

○ Meyer, I. (2018). Ästhetik, soziologische, en Müller y Reitz (2018). Simmel-Handbuch. Begriffe, Hauptwerke, Aktualität. Frankfurt am Main: Suhrkamp, pp. 131-136.

○ Montaigne, M. (2003). De la experiencia, en Ensayos completos. Madrid: Cátedra.

○ Moretti, G. (2013). Nimbus.: Nota sulla questione dell'aura in Ludwig Klages, en Rivista di estetica, Anno 53, n. 52, 2013, pp. 149-159.

- Morgan, B. (2012). Benjamin, Heidegger and the anthropology of everyday life, en Duttlinger, C.; Morgan, B.; Phelan, T. (eds.) (2012). Walter Benjamins Anthropologisches Denken. Rombach.

○ Müller, H. P. (2018). Einführung, en Müller y Reitz (2018). Simmel-Handbuch. Begriffe, Hauptwerke, Aktualität. Frankfurt am Main: Suhrkamp, pp. 11-90.

○ Müller, H.; Reitz, T. (2018). Simmel-Handbuch. Begriffe, Hauptwerke, Aktualität. Editado por Hans-Peter Müller y Tilman Reitz. Frankfurt am Main: Suhrkamp.

- Naishtat, F. (2005). Problemas filosóficos en la acción individual y colectiva: una perspectiva pragmática. Buenos Aires: Prometeo.

- Naishtat, F. (2008). La historiografía antiépica de W. Benjamin. La crítica de la narración en las Tesis Sobre el concepto de historia (1940) y su relación con los contextos de Das Passagen-Werk (1927-1940), en Cuadernos de Filosofía. Buenos Aires. FFyL-UBA. Vol. 1. $\mathrm{N}^{\mathrm{o}} 50$.

○ Naishtat, F. (2008b). Walter Benjamin: Teología y teología política. Una dialéctica herética, presentado en VII Jornadas de Investigación en Filosofía, La Plata, 11/2008. Disponible en: http://www.memoria.fahce.unlp.edu.ar/trab_eventos/ev.486/ev.486.pdf 
○ Naishtat, F. (2010). El psicoanálisis a prueba de fragmentos. La recepción de Freud en la historiografía de los Passagen-Wek (Walter Benjamin), en Acha, O. (comp.), Inconsciente e historia después de Freud. Cruces entre filosofía, psicoanálisis e historiografía. Buenos Aires: Prometeo, pp. 35-51.

○ Naishtat, F. (2010b). Los 'giros' filosóficos y su impronta metafilosófica, en Nudler, O. (2010). (editor) Filosofía de la filosofía. Enciclopedia iberoamericana de filosofía, Volumen 31. Madrid: Trotta.

○ Naishtat, F. (2011). Walter Benjamin: El exilio, los Pasajes y las huellas, en Litoral. Revue lacanienne de psychanalyse, $\mathrm{N}^{\circ}$ 43. México D.F., pp. 213-232.

○ Naishtat, F. (2011b). El exilio francés de Walter Benjamin y el Libro de los pasajes, en Burello, M., Ludueña Romandini, F. y Taub, E. (Eds.) (2011). Políticas del Exilio. Orígenes $y$ vigencia de un concepto. Buenos Aires: Eduntref, pp. 239-264.

- Naishtat, F. (2015). La tarea de la crítica en Benjamin como parte de una nueva Ilustración, (Expuesto en el Simposio Internacional "Walter Benjamin: ilustración y secularización” en marzo del 2015 y en prensa).

○ Naishtat, F. (2016). Theology and the Understanding of Experience in Benjaminian Philosophy of History, ponencia en la 2nd Conference of the International Network for Theory of History: The Practical Past: On the Advantages and Disadvantages of History for Life, Ouro Preto.

○ Naishtat, F. (2017a). El órganon invisible. La gramática teológica del tiempo benjaminiano, en Enrahonar N 58.

○ Naishtat, F. (2017b). Tiempo, ruina y salvación en Martin Heidegger y Walter Benjamin. XI Jornadas de Investigación del Departamento de Filosofía FaHCE-UNLP, 8 al 11 de agosto de 2017, Ensenada, Argentina. En Actas publicadas. La Plata: Universidad Nacional de La Plata. Facultad de Humanidades y Ciencias de la Educación.

○ Naishtat, F.; Gallegos, E. G.; Yébenes, Z. (coords.) (2015). Ráfagas de dirección múltiple. Abordajes de Walter Benjamin. Ciudad de México: Universidad Autónoma Metropolitana, Unidad Cuajimalpa.

○ Ng, J. (2011). Each Thing a Thief: Walter Benjamin on the Agency of Objects, en Philosophy \& Rhetoric, 44(4), pp. 382-402.

- Nudler, O. (2004). Hacia un modelo de cambio conceptual: espacios controversiales y refocalización, en Revista de Filosofía V.29 No2, pp. 7-19.

○ Ogden, B. (2010). Benjamin, Wittgenstein, and Philosophical Anthropology: A Reevaluation of the Mimetic Faculty, en Grey Room, (39), pp. 57-73. 
○ Opitz, M.; E. Wizisla (comps.) (2014). Conceptos de Walter Benjamin, trad. M. Belforte y M. Vedda. Buenos Aires: Las cuarenta.

- Oyarzún, P. (1998). Indagaciones sobre el concepto de experiencia, en Seminarios de filosofia, $\mathrm{N}^{\mathrm{o}}$ 11, 1998, pp. 123-134.

○ Oyarzún, P. (2008). Introducción, en Benjamin, W. (2008). El narrador. Santiago de Chile, Metales pesados, pp. 7-52.

- Parente, D. (2010a). Del órgano al artefacto. Acerca de la dimensión biocultural de la técnica. La Plata: Edulp.

o Parente, D. (2010b). De la Zuhandenheit a la Machenschaft. El tránsito heideggeriano hacia un concepto unidimensional de la técnica, en Catoggio, L. y Parente, D. (comps.), Decir el abismo. Lecturas de Heidegger y su obra en la década del 30. Mar del Plata: Eudem, pp. 65-91.

○ Picotti, D. (2010). Heidegger: una introducción. Buenos Aires: Quadrata.

○ Pöggeler, O. (1993). El camino del pensar de Martin Heidegger. Madrid: Alianza.

- Preciado, P. B. (2009). Un apartamento en Urano. Crónicas del cruce. Barcelona: Anagrama.

○ Presas, M. (2013). La recepción estética, en D. Sobrevilla y J. Xirau (coords.), Estética, Trotta, Madrid, pp. 123-144.

- Proust, M. (1999). En busca del tiempo perdido. El mundo de Guermantes (Trad. P. Salinas). Buenos Aires: Pluma y papel.

○ Ramírez, C. A. (2009). “Todos son genios” La crítica a la estetización de la acción política en Carl Schmitt, en Revista de Estudios Sociales 34, Estética y Política I, pp. 59-71.

○ Rancière, J. (2010). El espectador emancipado, trad. A. Dilon, Buenos Aires: Manantial.

- Rebentisch, J. (2012). Die Kunst der Freiheit. Zur Dialektik demokratischer Existenz. Frankfurt: Suhrkamp.

○ Rehberg, K.S (2018). Tragödie der Kultur, en Müller y Reitz (2018). Simmel-Handbuch. Begriffe, Hauptwerke, Aktualität. Frankfurt am Main: Suhrkamp, pp. 566-572.

- Rendueles, C. (2013). El antropólogo de la vida moderna, en Barja, J; Rendueles, C. (eds). (2013). Mundo escrito: 13 derivas desde Walter Benjamin. Madrid: Círculo de Bellas Artes, pp. $165-178$.

○ Rendueles, C. (2014). "Slavoj Žižek. Verdad y emancipación en la era postmetafísica” en Logos. Anales del Seminario de Metafísica, Vol. 47, pp. 259-280. 
○ Rendueles, C. (2016). En bruto. Una reivindicación del materialismo histórico. Madrid: Los libros de la catarata.

○ Rendueles, C.; López Arnal, S. (2011). Entrevista a César Rendueles, editor de una nueva antología castellana de textos de El Capital de Marx, en Sin Permiso, N 17, 06/02/2011.

- Reyes Mate, M. (2009). Medianoche en la historia. Comentarios a las tesis de Walter Benjamin "Sobre el concepto de historia". Madrid: Trotta.

○ Richter, G. (2010). Una cuestión de distancia. La calle de dirección única de Benjamin a través de los pasajes, en Uslengui, A. (comp.), Walter Benjamin: culturas de la imagen. Buenos Aires: Eterna cadencia, pp. 237-282.

○ Richter, G. (2015). Critique and the Thing: Benjamin and Heidegger, en Benjamin, A., Vardoulakis, D. (eds.) (2015). Sparks Will Fly: Benjamin and Heidegger. New York: State University of New York Press, pp. 27-63.

○ Ríos Rojas, A. (2015). Tristán e Isolda de Wagner y la filosofía romántica. Novalis y Schopenhauer en Wagner, en Thémata. Revista de Filosofía No51, enero-junio (2015) pp. 343-361.

○ Rivera, J.; Stuven, M. (2008). Comentario a Ser y tiempo, de Martin Heidegger. Vol I. Santiago de Chile: Universidad Católica de Chile.

o Rockmore, T. (1992). Heidegger's Nazism and Philosophy. Berkeley: University of California Press.

○ Rorty, R. (1978). Philosophy as a Kind of Writing: An Essay on Derrida, en New Literary History, 10(1), pp. 141-160.

○ Rorty, R. (1998). El giro lingüístico. Barcelona: Paidós.

○ Rosenthal, G. (1990). Narración y significado biográfico de las experiencias de guerra, en Historia y fuente oral, (4), pp. 119-128.

- Rowe, D. (1995). Georg Simmel and the Berlin Trade Exhibition of 1896, en Urban History, Volume 22, Issue 02, pp. 216-228.

- Rueda, L.; Staroselsky, T. (2020). Hacia otra comprensión de lo social en el arte: Dewey y Benjamin, en Capasso, V., Bugnone, A. y Fernández, C. (coords). Estudios sociales del arte. Una mirada transdisciplinaria. La Plata: Edulp.

○ Ruiz Zamora, M. (2006). Martin Heidegger/ Walter Benjamin: un antagonismo a partir de la obra de arte, en Thémata. Núm. 36, pp. 255-262.

- Sabido Ramos, O. (2016). Capítulo 9. Alcances teórico-metodológicos de la sociología relacional de Georg Simmel. El caso reciente de la sociología de los sentidos, en Vernik, E. 
y Borisonik, H. [eds.], Georg Simmel, un siglo después: actualidad y perspectiva, CABA: IIGG-Clacso, pp. 149-165.

- Safranski, R. (2003). Un maestro de Alemania. Martin Heidegger y su tiempo. Barcelona: Tusquets.

○ Sánchez Alarcón, M. I. (1996). Leni Riefenstahl: la estética del triunfo, en Historia y comunicación social, $\mathrm{N}^{\circ} 1,1996$, pp. 301-317.

O Schmider, C. y Werner, M. (2011). Das Baudelaire-Buch, en Lindner, B. (Hrsg.). (2011). Benjamin Handbuch. Leben - Werk - Wirkung. Stuttgart/ Weimar: J.B. Metzler.

○ Schöttker, D. (2014). Recordar, en Opitz, M y Wizisla, E. (2014). Conceptos de Walter Benjamin. Buenos Aires: Las cuarenta, pp. 955-1012.

○ Schultz, J.; Sello, S. (2018). Distanz, en Müller y Reitz (2018). Simmel-Handbuch. Begriffe, Hauptwerke, Aktualität. Frankfurt am Main: Suhrkamp, pp. 166-172.

- Schulze, G. (1992). Die Erlebnisgesellschaft: Kultursoziologie der Gegenwart. Frankfurt: Campus.

- Schwebel, P. (2015). Monad and Time: Reading Leibniz with Heidegger, en Benjamin, A.; Vardoulakis, D. (eds.) (2015). Sparks Will Fly: Benjamin and Heidegger. New York: State University of New York Press, pp. 123-144.

- Scott, J. W. (1991). The evidence of experience, en Critical Inquiry 17, ${ }^{\circ}{ }^{4}$, verano de 1991, pp. 773-797.

o Simmel, G. (1976). Filosofía del dinero. Madrid: Instituto de Estudios Políticos.

○ Simmel, G. (1992). Soziologische Ästhetik, en Simmel, G. (1992). Gesamtausgabe. Bd. 5. Frankfurt am Main: Suhrkamp.

○ Simmel, G. (1995). Die Großstädte und das Geistesleben, en Simmel, G. (1995). Gesamtausgabe. Bd. 7. Frankfurt am Main: Suhrkamp.

- Simmel, G. (1996). Philosophie des Geldes. Gesamtausgabe. Bd. 6. Frankfurt am Main: Suhrkamp.

○ Simmel, G. (2001a). Philosophie der Landschaft, en Simmel, G. (2001). Gesamtausgabe. Bd. 12. Frankfurt am Main: Suhrkamp.

- Simmel, G. (2001b). Sociología de la comida, en Simmel, G. (2001). El individuo y la libertad. Ensayos de crítica de la cultura. Barcelona: Ediciones Península.

- Simmel, G. (2001c). Filosofía del paisaje, en Simmel, G. (2001). El individuo y la libertad. Ensayos de crítica de la cultura. Barcelona: Ediciones Península. 
- Simmel, G. (2001d). Las grandes urbes y la vida del espíritu, en Simmel, G. (2001). El individuo y la libertad. Ensayos de crítica de la cultura. Barcelona: Ediciones Península.

○ Simmel, G. (2005). Berliner Gewerbe-Ausstellung, en Simmel, G. (2005). Gesamtausgabe. $B d$. 17. Frankfurt am Main: Suhrkamp.

○ Simonis, L. (1996). Walter Benjamin Theorie der Erfahrung, en Études Germaniques, vol. 51, 1996, No. 1, pp. 81-98.

o Simonis, L. (1999). Reflexion der Modeme im Zeichen von Kunst. Max Weber und Georg Simmel zwischen Entzauberung und Ästhetisierung, en von Graevenitz, G. (comp.) (1999). Konzepte der Moderne. Stuttgart, Weimar: Metzler.

○ Sloterdijk, P. (2011). Sin salvación. Tras las huellas de Heidegger. Madrid: Akal.

- Solana, M. (2020). Giro afectivo y giro a la imagen: un encuentro indisciplinado, en Heterotopías, 3(5), pp. 1-6.

- Solas, S. (2006). La concepción pictórica en la novela proustiana, en Moran, J. C. (2006). Proust ha desaparecido. Una memoria de los paraísos perdidos. La Plata: Prometeo.

○ Sontag, S. (2007). Bajo el signo de Saturno. Barcelona: De bolsillo.

o Sontag, S. (2007a). Fascinante fascismo, en Sontag, S. (2007). Bajo el signo de Saturno. Madrid: de bolsillo.

○ Sontag, S. (2007b). Un argumento sobre la belleza, en Sontag, S. (2007). Al mismo tiempo. Ensayos y conferencias. Barcelona: Mondadori.

- Staroselsky, T. (2018). El problema de la estetización en la filosofía de Walter Benjamin, en Diánoia. Revista de Filosofía, Vol. 63, Núm. 81. Ciudad de México: Universidad Nacional Autónoma de México.

O Staroselsky, T. (2020a). Entre la imagen y el concepto: Walter Benjamin y Joseph Kosuth, en Ágora. Papeles de Filosofía, Vol. 39, N 1 (2020). Santiago de Compostela: Facultade de Filosofía, Universidade de Santiago de Compostela.

o Staroselsky, T. (2020b). Una flor imposible. Walter Benjamin y la experiencia en crisis, en Resistances. Journal of the Philosophy of History, Vol. 1, N 1 . Quito: Cicshal-Religacion.

o Steiner, U. (2001). The True Politician: Walter Benjamin's Concept of the Political, en New German Critique, No. 83, Special Issue on Walter Benjamin (Spring - Summer, 2001), pp. 43-88.

○ Steiner, U. (2002). 'Das Höchste wäre: zu begreifen, dass alles Factische schon Theorie ist'. Walter Benjamin liest Goethe, en Zeitschrift für deutsche Philologie, 121. Band, 2002, pp. 265-284. 
o Steiner, U. (2010). Walter Benjamin, an introduction to his work and though. Chicago: University of Chicago Press.

o Steiner, U. (2014). Crítica, en Opitz, M y Wizisla, E. (2014). Conceptos de Walter Benjamin. Buenos Aires: Las cuarenta, pp. 241-304.

○ Stern, A. (2019). The Fall of Language: Benjamin and Wittgenstein on Meaning. Cambridge, London: Harvard University Press.

o Stollmann, R. (1978). Fascist Politics as a Total Work of Art: Tendencies of the Aestheticization of Political Life in National Socialism, en New German Critique 14, pp. 41-60.

- Sztulwark, D. (2019). La ofensiva sensible. Neoliberalismo, populismo y el reverso de lo político. Buenos Aires: Caja Negra.

- Taccetta, N. (2015). Benjamin, Schmitt, Agamben y el estado de excepción, en Devenires, xvi, 32, pp. 13-38.

○ Thouard, D. (2018). Philosophie, en Müller y Reitz (2018). Simmel-Handbuch. Begriffe, Hauptwerke, Aktualität. Frankfurt am Main: Suhrkamp, pp. 417-423.

○ Truskolaski, S.; Sieber, J. (2017). The Task of the Philosopher, en Anthropology \& Materialism, Special Issue | I | 20173.

o Valery, P. (1999). La conquista de la ubicuidad, en Valery, P. (1999). Piezas sobre arte. Madrid: Visor.

O Vardoulakis, D. (2015). A Matter of Immediacy: The Political Ontology of the Artwork in Benjamin and Heidegger, en Benjamin, A.; Vardoulakis, D. (eds.) (2015). Sparks Will Fly: Benjamin and Heidegger. New York: State University of New York Press, pp. 237-257.

○ Vargas, M. (2015). Culpa, inmanencia y dinero: comentario a "Capitalismo como religión" de Walter Benjamin, en Naishtat, F., Gallegos, E. G. y Yébenes, Z. (coords.) (2015). Ráfagas de dirección múltiple. Abordajes de Walter Benjamin. Ciudad de México: UAM Cuajimalpa, pp. 387-413.

- Vargas, M. (2018). Variaciones semánticas del concepto de crisis en Walter Benjamin, en Páginas de Filosofía, Año XIX, № 22 (enero-diciembre 2018), pp. 33-50.

- Vattimo, G. (1987). El fin de la Modernidad. Nihilismo y hermenéutica en la cultura posmoderna, trad. A.L. Bixio, Gedisa, Barcelona.

- Vedda, M. (comp.) (2008). Constelaciones dialécticas. Tentativas sobre Walter Benjamin. Buenos Aires: Herramienta. 
○ Vera Barros, T. (2015). Introducción: Walter Benjamin: estética y experiencia, en Benjamin, W. (2015a), pp. 13-24.

- Viglione, M. P. (2018). El lugar de la teología y sus derivas en la temporalidad: un contrapunto entre los escritos de Martin Heidegger y Walter Benjamin en la década del veinte, en Páginas de Filosofía, Año XIX, No 22 (enero-diciembre 2018), pp. 51-76.

○ Vilar, G. (2012). La estetización de la imagen violenta en el arte contemporáneo, en Ana García Varas (ed.), Filosofía e(n) imágenes. Zaragoza: Institución Fernando el Católico.

- Villanueva, L; Uhart, H. (2015). Las clases de Hebe Uhart. Buenos Aires: Blatt y Ríos.

- Volpi, F. (1994). La existencia como práxis. Las raíces aristotélicas de la terminología de Ser y Tiempo. En Vattimo, G.(comp.) (1994). Hermenéutica y racionalidad. Colombia: Norma, pp. 327-383.

○ Volpi, F. (2008). Goodbye, Heidegger! Mi introducción censurada a los Beiträge zur philosophie. Fenomenología y hermenéutica, en Actas del I Congreso Internacional de Fenomenología y Hermenéutica, pp. 43-63.

○ Volpi, F. (2009). Ser y Tiempo: ¿una versión moderna de la Ética Nicomaquea?, en Rocha de la Torre, A. (ed.) (2009). Martin Heidegger. La experiencia del camino. Barranquilla: Ediciones de la Universidad del Norte.

○ Volpi, F. (2012). Heidegger y Aristóteles. Buenos Aires: Fondo de Cultura Económica.

○ Weber, S. (2008). Benjamin's -abilities. Cambridge-London: Harvard University Press.

○ Weber, T. (2014). Experiencia, en Opitz, M y Wizisla, E. (2014). Conceptos de Walter Benjamin. Buenos Aires: Las cuarenta, pp. 479-525.

○ Weidmann, H. (2014). Despertar/Sueño, en Opitz, M. y Wizisla, E. (2014), Conceptos de Walter Benjamin. Buenos Aires: Las cuarenta, pp. 305-337.

○ Weidner, D. (2019). Fort-, Über-, Nachleben Zu einer Denkfigur bei Benjamin, en Weidner, D y Weigel, S. (Hrsg.) (2019) Benjamin-Studien 2. Wilhelm Fink.

○ Weigel, S. (1999). Cuerpo, imagen y espacio en Walter Benjamin. Una relectura. Buenos Aires: Paidós.

○ Welsch, W. (1991). Ästhetik und Anästhetik, en Welsch y Pries (1991). Ästhetik im Widerstreit. Interventionen zum Werk von Jean-Francois Lyotard. Weinheim: VCH, Acta humaniora.

○ Welsch, W. (1996). Aestheticization Processes: Phenomena, Distinctions and Prospects, en Theory Culture Society, 1996 13, pp. 1-24. 
○ Welsch, W.; Pries, Ch. (1991). Einleitung, en Welsch y Pries (1991). Ästhetik im Widerstreit. Interventionen zum Werk von Jean-Francois Lyotard. Weinheim: VCH, Acta humaniora.

o Wheeler, B. R. (2002). Modernist Reechantments II: From Aestheticized Politics to the Artwork, en The German Quarterly, Vol. 75, No. 2 (Spring, 2002), pp. 113-126.

○ Wiggershaus, R. (2010). La Escuela de Frankfurt. Buenos Aires, Fondo de Cultura Económica.

○ Wizisla, E. (2007). Benjamin y Brecht. Historia de una amistad. Buenos Aires: Paidós.

○ Wohlfarth, I. (2015). Tierra de nadie: sobre 'El carácter destructivo' de Walter Benjamin, en Cohen, E. (ed.) (2015). Walter Benjamin. Resistencias minúsculas. Buenos Aires: Ediciones Godot, pp. 103-152.

o Young, J. (1997). Heidegger, Philosophy, Nazism. Cambridge: Cambridge University Press.

○ Zimmerman, M. E. (1990). Heidegger's Confrontation with Modernity. Technology, Politics and Art. Bloomington/ Indianápolis: Indiana University Press.

○ Žižek, S. (2008). Arte e ideología en Hollywood. Una defensa del platonismo, en Arte, ideología y capitalismo. Madrid: Ediciones Pensamiento.

○ Zumbusch, C. (2004). Wissenschaft in Bildern. Symbol und dialektisches Bild in Aby Warburgs MnemosyneAtlas und Walter Benjamins Passagen-Werk. Berlin: Akademie Verlag. 